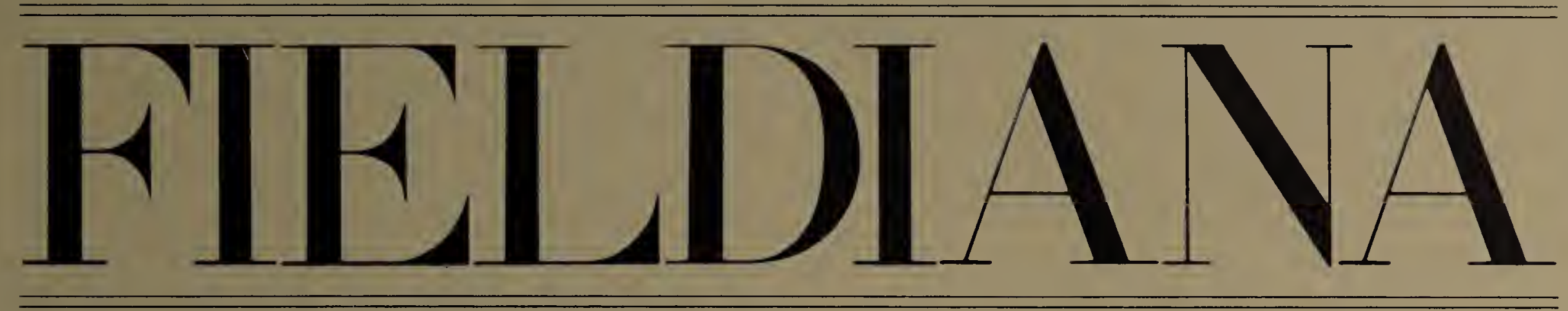

\title{
Botany
}

NEW SERIES, NO. 46

\section{A First Assessment of the Ticolichen Biodiversity Inventory in Costa Rica: The Genus Graphis, with Notes on the Genus Hemithecium (Ascomycota: Ostropales: Graphidaceae)}

\section{Robert Lücking}

Department of Botany, The Field Museum (Field Museum of Natural History)

Chicago, Illinois 60605-2496, USA

José Luis Chaves

Laboratorio de Hongos, Instituto Nacional de Biodiversidad (INBio)

Apdo. 22-3100, Santo Domingo de Heredia, Costa Rica

Harrie J. M. Sipman

Botanischer Garten \& Botanisches Museum, Berlin Dahlem

Königin-Luise-Strasse 6-8, D-14195 Berlin, Germany

\section{Loengrin Umaña}

Laboratorio de Hongos, Instituto Nacional de Biodiversidad (INBio)

Apdo. 22-3100, Santo Domingo de Heredia, Costa Rica

André Aptroot

ABL Herbarium, G.v.d. Veenstraat 107, NL-3762 XK Soest, The Netherlands

Publication July 3, 2008

Publication 1549 



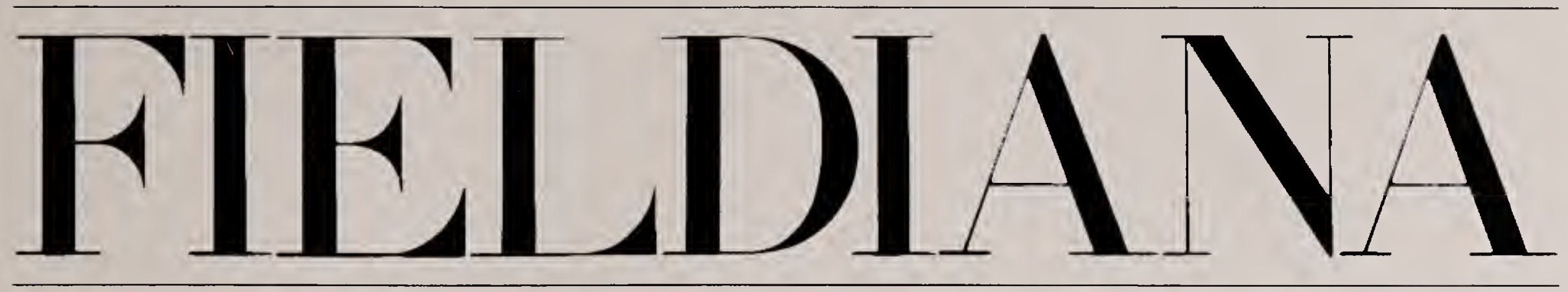

\section{Botany}

NEW SERIES, NO. 46

\section{A First Assessment of the Ticolichen Biodiversity Inventory in Costa Rica: The Genus Graphis, with Notes on the Genus Hemithecium (Ascomycota: Ostropales: Graphidaceae)}

\section{Robert Lücking}

Department of Botany

The Field Museum (Field Museum of Natural History) Chicago, Illinois 60605-2496, USA

\section{José Luis Chaves}

Laboratorio de Hongos

Instituto Nacional de Biodiversidad (INBio) Apdo. 22-3100, Santo Domingo de Heredia Costa Rica

Harrie J. M. Sipman

Botanischer Garten \& Botanisches Museum Berlin Dahlem

Königin-Luise-Strasse 6-8

D-14195 Berlin, Germany

Accepted February 13, 2008

Published July 3, 2008

Publication 1549
Loengrin Umaña

Laboratorio de Hongos

Instituto Nacional de Biodiversidad (INBio)

Apdo. 22-3100, Santo Domingo de Heredia

Costa Rica

\section{André Aptroot}

ABL Herbarium, G.v.d. Veenstraat 107

NL-3762 XK Soest, The Netherlands 
(C) 2008 Field Museum of Natural History

ISSN 0015-0746

PRINTED IN THE UNITED STATES OF AMERICA 


\section{Table of Contents}

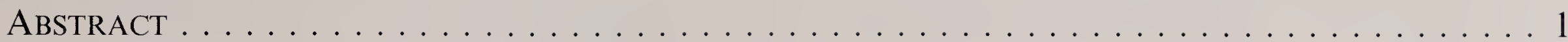

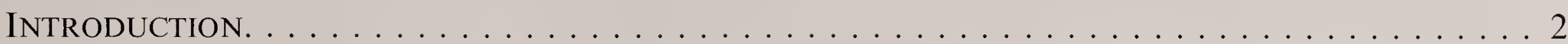

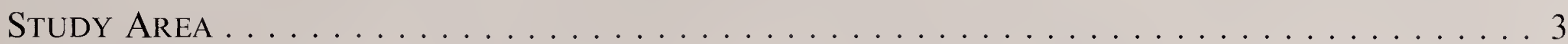

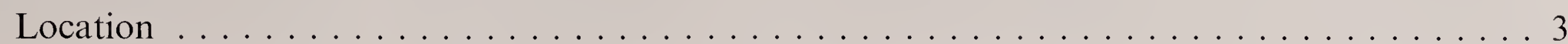

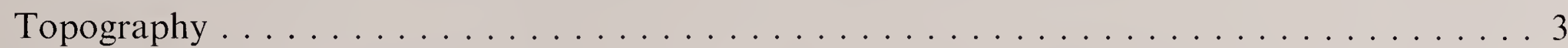

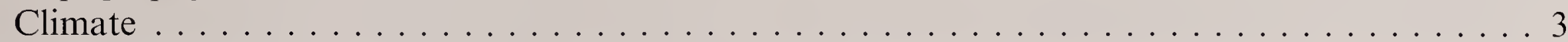

Vegetation ............................... 4

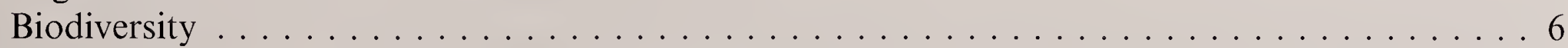

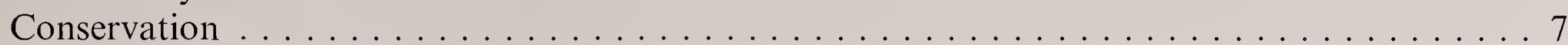

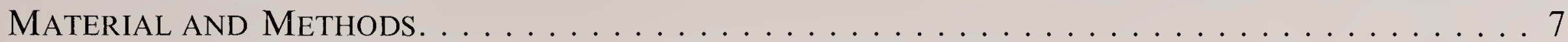

THE Lichen FAMILY GRAPHIDACEAE AND THE GENUS GRAPHIS $\ldots \ldots \ldots \ldots \ldots \ldots \ldots \ldots \ldots 8$

General Remarks . . . . . . . . . . . . . . . . . . . . . . . . 8

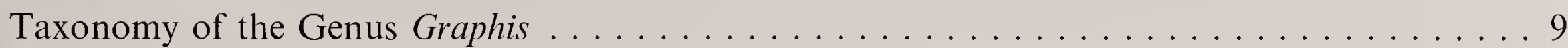

The Genus Graphis in Costa Rica. . . . . . . . . . . . . . . . . . . . . . . . . 20

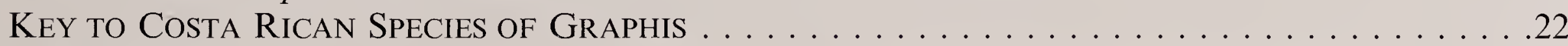

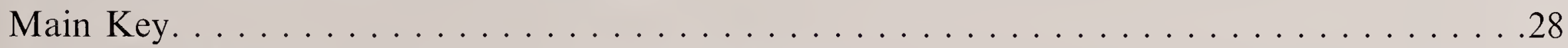

Group I: Lirellae with External or Internal Pigments . . . . . . . . . . . . . . . . . 28

Group II: Labia Entire, Excipulum Apically to Peripherally Carbonized . . . . . . . . . . . . 28

Group III: Labia Entire, Excipulum Laterally Carbonized . . . . . . . . . . . . . . . . . . . . . . . .29

Group IV: Labia Entire, Excipulum Completely Carbonized. . . . . . . . . . . . . . . . . . . . . . 29

Group V: Labia Striate, Excipulum Apically to Peripherally Carbonized . . . . . . . . . . . .32

Group VI: Labia Striate, Excipulum Laterally Carbonized . . . . . . . . . . . . . . . . . . 33

Group VII: Labia striate, Excipulum Completely Carbonized . . . . . . . . . . . . . . . . . 33

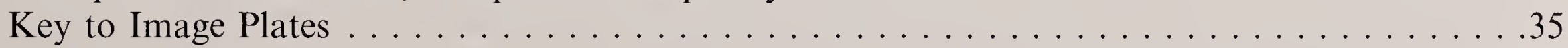

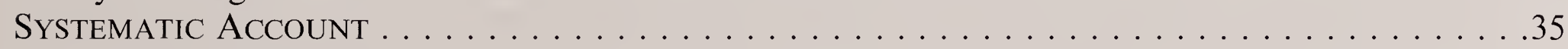

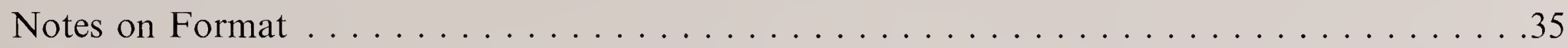

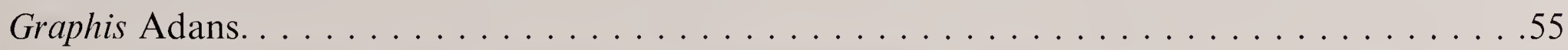

Multivariate Analysis of Habitat and Microhabitat Preferences $\ldots \ldots \ldots \ldots \ldots \ldots$

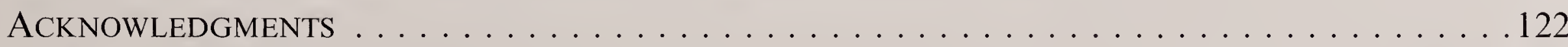

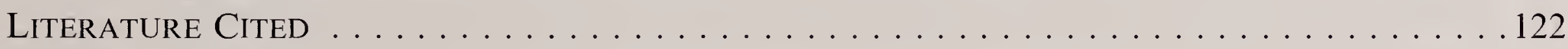

INDEX OF TAXA . . . . . . . . . . . . . . . . . . . . . . 127

\section{List of Illustrations}

1. Geographic situation of the study area and location of the collecting sites of the

TICOLICHEN inventory . . . . . . . . . . . . . . . . . . . . 4

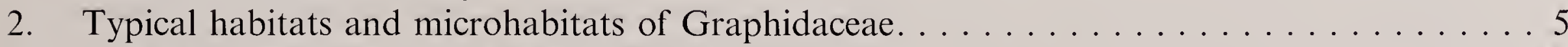

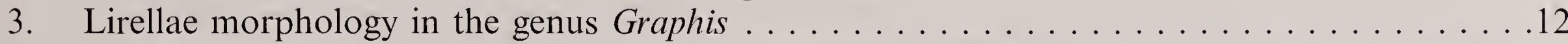

4. Schematic representation of excipular carbonization and lirellae morphotypes in the genus

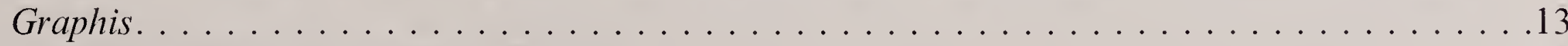

5. Ascospore types in the genus Graphis . . . . . . . . . . . . . . . . . . . 14

6. Number of collections of Graphis per altitudinal zone in Costa Rica . . . . . . . . . . . . .23

7. Species with pigments . . . . . . . . . . . . . . . . . . . . . . . 36

8. Species with transversely septate ascospores and apically carbonized excipulum . . . . . . 37

9. Species with transversely septate ascospores (small to medium sized) and laterally carbonized

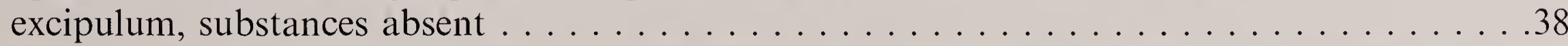

10. Species with transversely septate ascospores (small to medium sized) and laterally carbonized excipulum, substances present. . . . . . . . . . . . . . . . . . . . . . . . . . 39

11. Species with transversely septate ascospores (small) and laterally carbonized excipulum, hymenium inspersed 
12. Species with transversely septate ascospores (small) and completely carbonized excipulum, substances absent . . . . . . . . . . . . . . . . . . . . . . . . .41

13. Species with transversely septate ascospores (small to medium sized) and completely carbonized excipulum (or apically and basally carbonized), substances absent . . . . . . . 42

14. Species with transversely septate ascospores and completely carbonized excipulum, hymenium inspersed or substances present . . . . . . . . . . . . . . . .43

15. Species with transversely septate ascospores (large to very large) and completely carbonized excipulum, substances absent . . . . . . . . . . . . . . . . . . . . . . .44

16. Species with transversely septate ascospores (large to very large) and completely carbonized excipulum, hymenium inspersed or substances present . . . . . . . . . . . . 45

17. Species with terminally muriform ascospores (large) and completely carbonized excipulum . .46

18. Species with muriform ascospores (small) and apically carbonized excipulum, substances

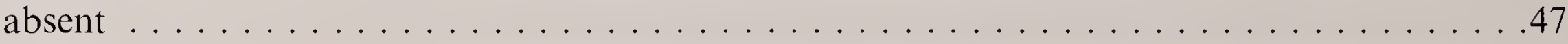

19. Species with muriform ascospores (medium sized to large) and apically carbonized excipulum (or apically and basally carbonized), substances absent . . . . . . . . . . . . . . 48

20. Species with muriform ascospores and apically carbonized excipulum, substances present . . .49

21. Species with muriform ascospores and laterally carbonized excipulum, substances absent or

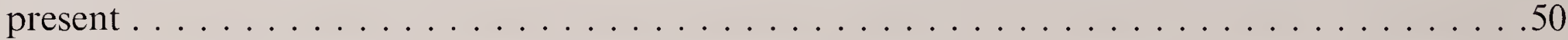

22. Species with muriform ascospores and completely carbonized excipulum, substances absent. .51

23. Species with muriform ascospores (large) and completely carbonized excipulum, substances

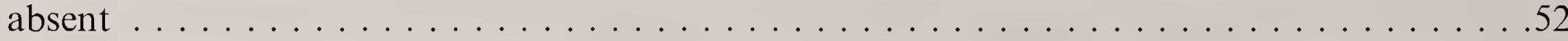

24. Species with muriform ascospores (medium sized to very large) and completely carbonized

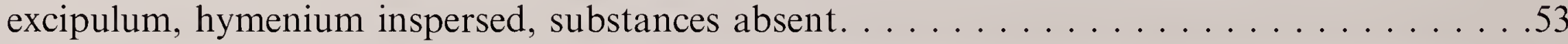

25. Species with muriform ascospores (large) and completely carbonized excipulum, substances

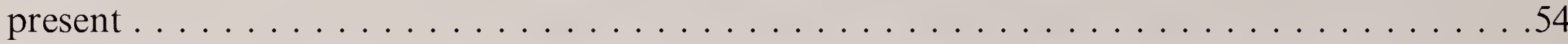

26. PCA ordination of 90 species of Graphis according to their weighted average scores,

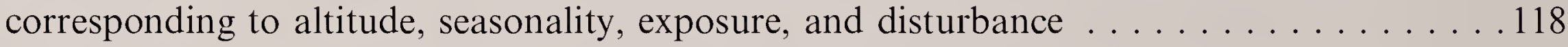

27. ANOVA box plot of 90 species of Graphis according to their weighted average scores corresponding to altitude . . . . . . . . . . . . . . . . . . . . . . . . . . 119

28. ANOVA box plot of 90 species of Graphis according to their weighted average scores corresponding to seasonality. . . . . . . . . . . . . . . . . . . . . . . 120

29. ANOVA box plot of 90 species of Graphis according to their weighted average scores corresponding to exposure . . . . . . . . . . . . . . . . . . . . . . 120

30. ANOVA box plot of 90 species of Graphis according to their weighted average scores

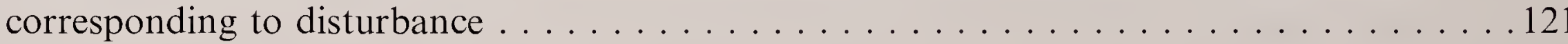

\section{List of Tables}

1. Definition and coding of four environmental parameters used for the multivariate analysis . . 8

2. Genera (and subgenera) currently distinguished in Graphidaceae, in presumed systematic order, and their main diagnostic characters . . . . . . . . . . . . . . . . . . . 10

3. List of species of Graphis reported and accepted from Costa Rica . . . . . . . . . . . . . . 18

4. List of names of Graphis and Graphina reported by Müller Argoviensis and Breuss, identified

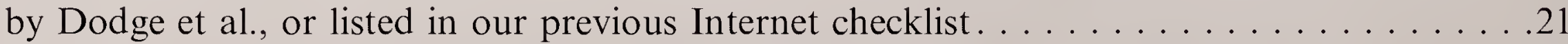

5. Costa Rican species of Graphis arranged according to major artificial key groups . . . . . . .24

6. Comparison of names described in the Graphis scripta group . . . . . . . . . . . . . . . 108 


\title{
A First Assessment of the Ticolichen Biodiversity Inventory in Costa Rica: The Genus Graphis, with Notes on the Genus Hemithecium (Ascomycota: Ostropales: Graphidaceae)
}

\author{
Robert Lücking, José Luis Chaves, Harrie J. M. Sipman, \\ Loengrin Umaña, and André Aptroot
}

\begin{abstract}
The genus Graphis sensu Staiger is treated as a further contribution to the TICOLICHEN biodiversity inventory in Costa Rica. Graphis s.str. is the largest tropical lichen genus, with more than 300 accepted species worldwide, and also the largest in Costa Rica, with a total of 115 species recognized in this work. The following 25 species are described as new: Graphis altamirensis Sipman \& Lücking sp. nov., G. argentata Lücking \& Umaña sp. nov., G. bettinae Lücking, Umaña, Chaves \& Sipman sp. nov., G. duplicatoinspersa Lücking sp. nov., G. firferi Lücking sp. nov., G. flavoaltamirensis Sipman \& Lücking sp. nov., G. flavominiata Moncada \& Lücking sp. nov., G. fournierii Lizano \& Lücking sp. nov., G. gomezii Lücking, Will-Wolf \& Umaña, G. gregmuelleri Sipman \& Lücking, sp. nov., G. hypocrellina Lücking \& Chaves sp. nov., G. inspersostictica Sipman \& Lücking sp. nov., G. litoralis Lücking, Sipman \& Chaves sp. nov., G. mirabilis Lücking, Sipman, Umaña \& Chaves sp. nov., G. nudaeformis Lücking sp. nov., G. oryzaecarpa Lücking sp. nov., G. paradisserpens Sipman \& Lücking sp. nov., G. paraserpens Lizano \& Lücking sp. nov., G. pittieri Lücking, Umaña, Sipman \& Chaves sp. nov., G. pseudocinerea Lücking \& Umaña sp. nov., G. pseudoserpens Chaves \& Lücking sp. nov., G. subflexibilis Lücking \& Chaves sp. nov., G. subruiziana Sipman, Chaves \& Lücking sp. nov., G. subturgidula Lücking \& Sipman sp. nov., and G. tenoriensis Chaves \& Lücking sp. nov. Graphis immersoides Lücking, nom. nov. [Bas. Graphina immersa Müll. Arg.; non Graphis immersa Fink], Graphis subchrysocarpa Lücking, nom. nov. [Bas.: Phaeographina ochracea C. W. Dodge; non Graphis ochracea Hepp], and Graphis submarginata Lücking, nom. nov. [Bas. Graphis marginata G. Mey. \& Flot.; non Graphis marginata Raddi] are introduced as replacement names. Furthermore, 17 new combinations are proposed: $G$. bipartita (Müll. Arg.) Lücking, comb. nov., G. chondroplaca (Redinger) Lücking comb. et stat. nov., G. consanguinea (Müll. Arg.) Lücking, comb. nov., G. dichotoma (Müll. Arg.) Lücking, comb. nov., G. granulosa (Müll. Arg.) Lücking comb. nov., G. insulana (Fée) Lücking \& Sipman, comb. nov., G. lutea (Chevall.) Aptroot, comb. nov., G. multisulcata (Müll. Arg.) Lücking \& Chaves comb. nov., G. myrtacea (Müll. Arg.) Lücking, comb. nov., G. nuda (H. Magn.) Staiger \& Lücking, comb. nov., G. plurispora (Redinger) Lücking \& Chaves, comb. nov., G. puiggarii (Müll. Arg.) Lücking, comb. nov., G. rhizocola (Fée) Lücking \& Chaves, comb. nov. [syn. G. anguilliformis Taylor; G. serpens Fée], G. subcontorta (Müll. Arg.) Lücking \& Chaves, comb. nov., G. subhiascens (Müll. Arg.) Lücking comb. nov., G. xylophaga (R. C. Harris) Lücking, comb. nov., and Hemithecium plicosum (Meissn.) Lücking \& Aptroot, comb. nov. [syn. Graphina malmei Redinger].

The new name Pallidogramme Staiger, Kalb \& Lücking, nom. nov. is introduced for Leucogramma A. Massal. [nom. illeg.; = Hemithecium subgen. Leucogramma Staiger], comprising a group of three species formerly included in Hemithecium: Pallidogramme
\end{abstract}


chapadana (Redinger) Staiger, Kalb \& Lücking, comb. nov., P. chlorocarpoides (Nyl.) Staiger, Kalb \& Lücking, comb. nov., and $P$. chrysenteron (Mont.) Staiger, Kalb \& Lücking, comb. nov.

More than 600 types of Graphidaceae suspected to represent species of Graphis s.str. were examined for this study, and notes on type material are given when appropriate. Also, the names previously reported for Costa Rica by the Swiss lichenologist Müller Argoviensis in 1891 and 1893 were checked when possible, and 175 unpublished collections from Costa Rica housed at the Farlow Herbarium (FH) of Harvard University and collected and identified by Carroll William Dodge and colleagues and students were revised.

A key is presented to all species, including an image-based identification guide, and diagnostic characters in the genus Graphis are briefly discussed and illustrated. Diagnoses and remarks are given for all species treated here, as are more detailed descriptions for the taxa new to science. Data from 803 collections were analyzed using the ordination technique of principal component analysis to display habitat and microhabitat preferences for species groups.

\section{Introduction}

Costa Rica is a neotropical realm of extraordinary biotic diversity (Groombridge, 1994; Obando, 2002) and has been the focus of the first author's lichenological studies ever since he set foot on Costa Rican soil 20 years ago in 1987. Although this tiny country covers only $0.5 \%$ of the area of the United States, the number of plant species (possibly 12,000) amounts to more than half of what is known from the United States $(20,000)$. A similar situation is found in lichens: while about 5000 species are estimated for the United States, at least about 2500 occur in Costa Rica (Umaña et al., 2002). Species density in Costa Rica is thus more than 100 times higher than in the United States and makes this country a primary area to study biodiversity and the mechanisms that maintain high species richness in tropical ecosystems.

Unfortunately, the taxonomy of tropical lichens is very incompletely known, which prevents more detailed studies on their biodiversity. The TICOLICHEN project seeks to close this gap and for the first time provides the opportunity to undertake a large-scale tropical lichen inventory in the framework of an international collaboration between more than 10 institutions in the United States, Costa Rica, Germany, The Netherlands, Austria, and Mexico. TICOLICHEN is a large-scale tropical lichen biodiversity inventory (Lücking et al., 2004), forming part of the Costa Rican Sustainable Biodiversity Development Initiative (Gámez et al., 1997), a collaborative effort to unravel Costa Rica's organismic diversity. TICOLI-
CHEN is a collaborative project between The Field Museum (Chicago), the Instituto Nacional de Biodiversidad (Costa Rica), and the Botanical Museum in Berlin (Germany), with collaboration of colleagues at the University of Wisconsin-Madison, the New York Botanical Garden, the University of Graz in Austria, and the ABL Herbarium in the Netherlands, and completes the surveys of Costa Rican macrofungi by Greg Mueller and Roy Halling (The Field Museum, New York Botanical Garden) and wood-inhabiting pyrenomycetes by Sabine Huhndorf and Fernando Fernández (The Field Museum), together compiling one of the world's largest inventories of tropical fungi. So far, no comprehensive tropical lichen inventory exists, let alone one that would meet the standards of treatments for Europe and North America (Purvis et al., 1992; Santesson, 1993; Wirth, 1995; Goward, 1999; Brodo et al., 2001; Nash et al., 2002, 2004). The available data are scattered throughout often hardly accessible literature, and local herbaria lack representative collections. Yet such an inventory is urgently needed to properly address tropical lichen diversity and its implications. The project also serves as model for survey work on lichens in other tropical countries and facilitates studies beyond taxonomy and biodiversity, including phylogeny, ecogeography, role in ecosystem function, use as bioindicators in conservation efforts, and potential medical and industrial applications based on secondary chemistry.

While a comprehensive treatment of all taxa is planned to be published in the near future, 
selected groups are being treated in advance in order to communicate new taxonomic findings and provide update identification tools. So far, the following treatments have been published or are under way: Arthonia (Grube et al., 2004), Coccocarpia (Lücking et al., 2007a), Coenogonium (Rivas Plata et al., 2006), Dictyonema (Chaves et al., 2004), Gyalideopsis (Lücking et al., 2006), Haematomma (Nelsen et al., 2006), Leptogium (Aptroot et al., in prep.), Lobaria (Chaves et al., in prep.), Phyllopsora (Trest et al., in prep.), Sarcographa (Lücking et al., in prep.), Sticta (Lücking et al., in prep.), the new genus Aptrootia (Lücking et al., 2007b), a new species of Multiclavula (Nelsen et al., 2007), the foliose Physciaceae (Will-Wolf et al., in prep.), Porinaceae (Lücking et al., in prep.), bitunicate pyrenocarpous taxa (Aptroot et al., 2008), Thelotremataceae (Sipman et al., in prep.), molecular phylogeny of the Heterodermia japonica group (Lücking et al., 2008a), and more than 400 foliicolous taxa (Lücking, 2008a).

The genus Graphis, which is treated in the present work, is symptomatic for many aspects and objectives of the TICOLICHEN project. With more than 300 species, Graphis is by far the largest genus of tropical crustose microlichens, a group that has been neglected but accounts for most of the diversity in tropical lichen biota. The present treatment also shows that the taxonomy of tropical microlichens is not as difficult as generally believed, provided that the necessary tools are at hand, and the generation of such tools during this project complies with one of the major objectives of TICOLICHEN. The number of 115 species recognized for Costa Rica is mindboggling, more so when considering that a wider species concept was applied here than that suggested in the recent revision of Staiger (2002) in that forms with entire and striate labia were not recognized as distinct species. This number exceeds our initial estimations by more than $100 \%$ and suggests that the overall lichen diversity of the country might be significantly higher than 2500 species.

While Graphis is only one out of more than 400 lichen genera occurring in the Neotropics and the present treatment is only a small part of our ongoing taxonomic revisions of selected groups, we hope that this work will particularly stimulate the study of tropical microlichens, especially since species of Graphis and Graphidaceae are very attractive because of their showy fruit bodies and are frequently collected even by nonspecialists.

\section{Study Area}

\section{Location}

Costa Rica is located on the southern part of the Central American land bridge, between $8^{\circ} 01^{\prime}$ and $11^{\circ} 13^{\prime} \mathrm{N}$ and $82^{\circ} 33^{\prime}$ and $85^{\circ} 58^{\prime} \mathrm{W}$ (Fig. 1). The country covers an area of $51,100 \mathrm{~km}^{2}$, bordering with Nicaragua to the north and Panama to the southeast. Costa Rica also possesses Cocos Island, the only wet oceanic island in the eastern Pacific, situated about $500 \mathrm{~km}$ southwest of Costa Rica.

\section{Topography}

Four major mountain ranges - the Cordilleras of Guanacaste, Tilarán, Volcánica Central, and Talamanca - cross the country from northwest to southeast, reaching $3819 \mathrm{~m}$ at the highest peak, Cerro Chirripó in the Cordillera de Talamanca. The mountain ranges divide the country in an Atlantic and a Pacific side, with extensive plains in the northeast on the Atlantic side and in the northwest and in the south on the Pacific side (Fig. 1). The Cordilleras of Guanacaste and Tilarán and the Cordillera Volcánica Central are composed mostly of ancient and partly active volcanoes, while volcanic activity ceased in the Cordillera de Talamanca (Pichler \& Weyl, 1975; Abratis \& Wörner, 2001; Marshall et al., 2003).

\section{Climate}

The climate is oceanic (Herrera, 1985; Coen, 1991). The northeastern Atlantic and the southern Pacific lowlands receive between 3000 and $6000 \mathrm{~mm}$ annual precipitation, with a marked dry season on the Pacific side between January and March. The northwestern Pacific lowlands are comparatively dry, with 1300 to $2000 \mathrm{~mm}$ annual precipitation and a marked dry season from December to April. The premontane and lower montane ranges of the Atlantic slopes of the Cordilleras receive extremely high annual precipitation with 5000 to $7000 \mathrm{~mm}$, while the Pacific slopes receive 3000 to $4500 \mathrm{~mm}$, accompanied by a distinct dry season. Above 2500-m altitude, annual precipitation is reduced to 2000 to $2500 \mathrm{~mm}$, but extended cloud cover is typical of many areas. Mean annual temperature is $26^{\circ} \mathrm{C}$ to $27.5^{\circ} \mathrm{C}$ at sea 


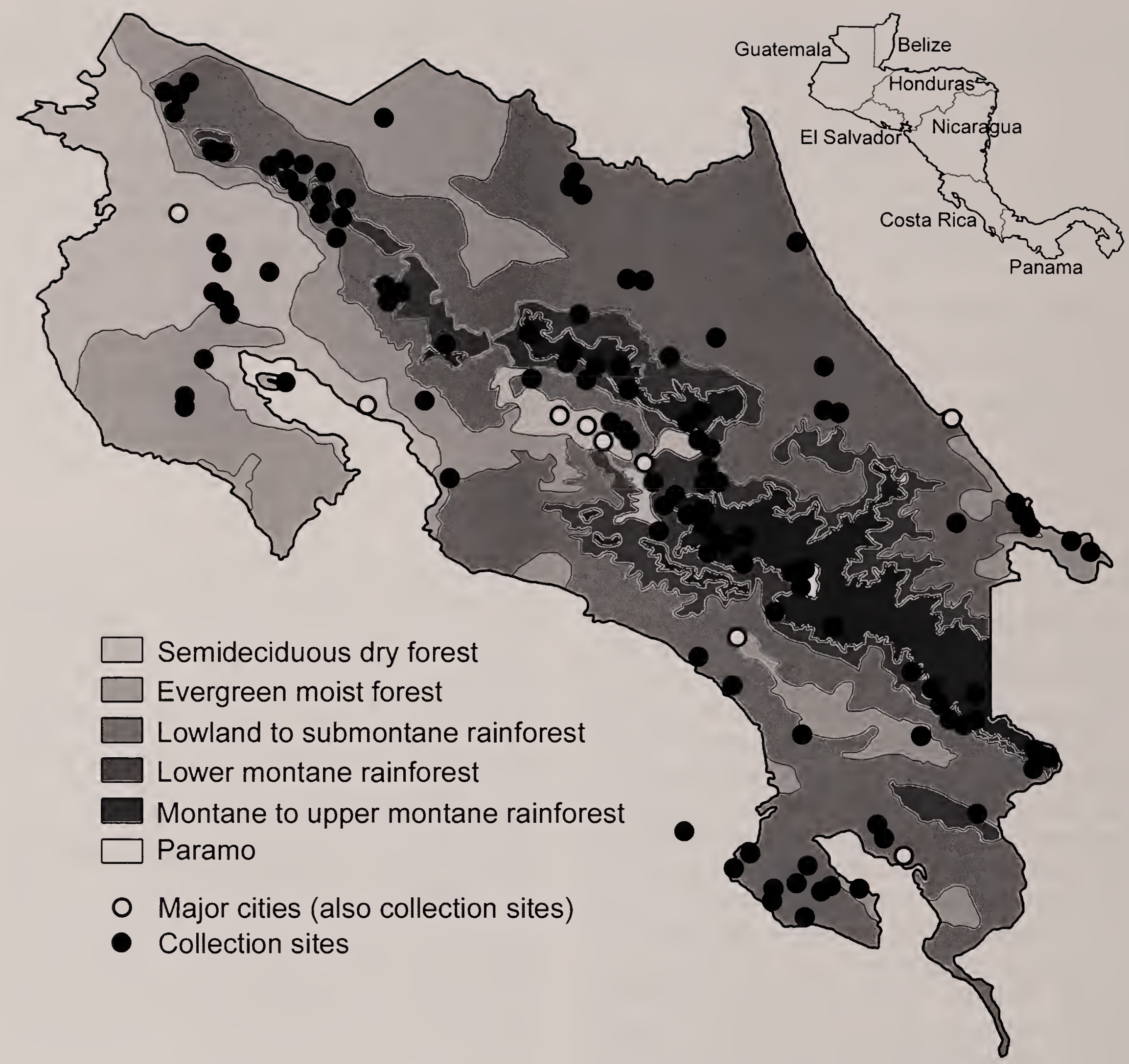

FIG. 1. Geographic situation of the study area and location of the collecting sites of the TICOLICHEN inventory.

level (Atlantic versus Pacific side) and decreases by about $0.5^{\circ} \mathrm{C}$ to $0.6^{\circ} \mathrm{C}$ per $100-\mathrm{m}$ altitude.

\section{Vegetation}

According to Holdridge et al. (1971) and Hartshorn (1991), Costa Rica shares 12 of the 38 world life zones defined by Holdridge (1947, 1967, 1982). These are delimited primarily by the amount of annual precipitation and by their temperature regime. The 12 life zones in Costa Rica comprise tropical rain, wet, moist, and dry forest, with the corresponding altitudinal subdivisions (lowland, premontane, lower montane, montane), as well as the subalpine rain paramo.
The life zones change approximately each 500 or $1000 \mathrm{~m}$ along the altitudinal gradient. The 12 life zones can be merged into six simplified life zone/ vegetation types that differ significantly in their lichen diversity and species composition, also with respect to Graphidaceae (Fig. 2): (1) semideciduous dry forest, (2) evergreen moist forest, (3) lowland to submontane rain forest, (4) lower montane rain forest, (5) montane to upper montane rain and cloud forest, and (6) paramo (Fig. 1).

Gómez (1986) provides a finer division of the vegetation occurring in Costa Rica, taking into consideration also the physiognomy and species composition and distinguishing 53 macrovegetation types. Among these are different types of 

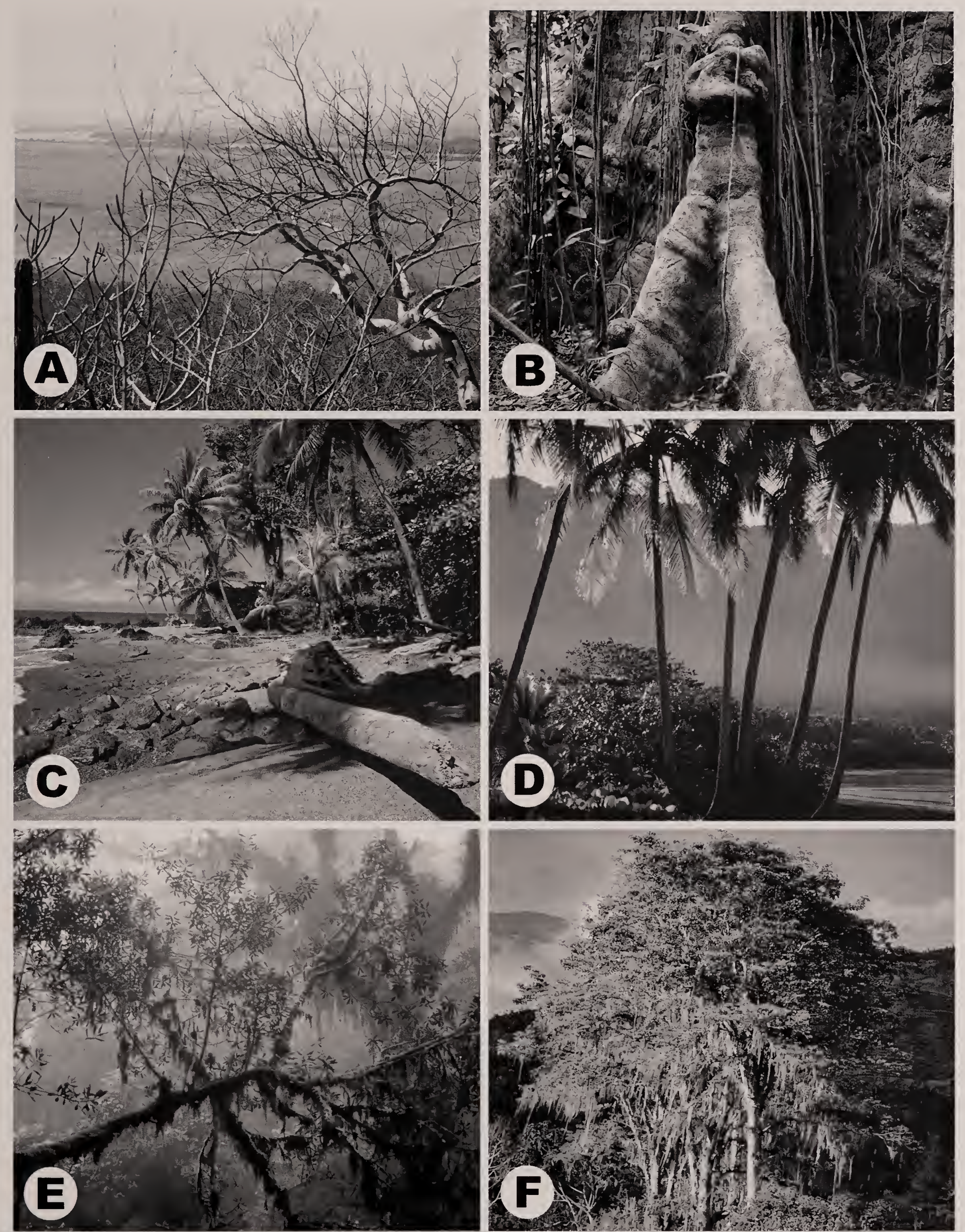

FIG. 2. Typical habitats and microhabitats of Graphidaceae. (A) Semideciduous dry forest (Palo Verde National Park); typical habitat for Glyphis cicatricosa, G. scyplulifera, G. substriatula, Graplis farinulenta, and G. seminuda. (B) Lowland rain forest (La Selva Biological Station); typical habitat for Graphis rhizocola. (C) Coastal rain forest (Marenco Biological Station); typical habitat for Sarcographa diffornis, S. heteroclita, S. labyrintlica, and S. ramificans. (D) Coastal vegetation (Ballena National Park); typical habitat for Graphis dendrogramma. (E) Cloud forest (Genesis II Cloud Forest Reserve); typical habitat for species of the Graphis cinerea and G. muda groups and for Leiorreunla spp. (F) Coffee plantation at midelevation $(1500 \mathrm{~m}$ ) with exposed Erythrina tree (Orosi Valley); typical habitat for Graphidaceae in general. 
savannas, which during the present study turned out to support a high diversity of Graphidaceae and several species new to science.

\section{Biodiversity}

Costa Rica is considered one of the 20 countries representing biodiversity hot spots in the world (Groombridge, 1994; Obando, 2002). The total number of species in all organismic groups is roughly estimated at 500,000, of which 360,000 are supposed to be insects (Obando, 2002). Besides Animalia, with a total of 380,000 species expected, Fungi are the second-largest kingdom, with about 65,000 expected species, followed by Monera $(26,000)$ and Viridiplantae $(13,000)$. Because of the country's small size, just $0.5 \%$ of that of the United States, Costa Rica exhibits by far the highest species density of any country in the world, by an order of magnitude higher than any other megadiverse country, such as Mexico, Colombia, Brazil, Indonesia, and Australia (García, 1997; Obando, 2002).

Costa Rica's organismic diversity began to be explored scientifically in the middle of the nineteenth century by the German physicians Karl Hoffmann and Alexander von Frantzius (Hilje, 2006). The first systematic flora of Costa Rica, Primitiae Florae Costaricensis, was initiated by the Swiss mining engineer Henry François Pittier at the end of the nineteenth century, and this work included a substantial treatment of lichens (Müller Argoviensis, 1891, 1893a). A detailed summary of the scientific activities following these endeavors during most of the twentieth century is given by Janzen (1974) in his Costa Rican Natural History. Several national and international organizations are mentioned therein that shaped the development of scientific expertise in Costa Rica from the 1950s on, including the National Museum (Museo Nacional), the Tropical Agricultural Center for Research and Teaching or Centro Agronómico Tropical de Investigación y Enseñanza (CATIE), the Tropical Science Center or Centro Científico Tropical (CCT), the National Park Service or Servicio de Parques Nacionales (predecessor of SINAC; see below), and especially the Organization for Tropical Studies (OTS), with their well-known field stations La Selva, Palo Verde, Santa Rosa, and Las Cruces. More recently, the Missouri Botanical Garden (MOBOT; www. mobot.org) became the driving force behind the systematic inventory of Costa Rican plants. Since 1989, the National Biodiversity Institute or Instituto Nacional de Biodiversidad (INBio; www.inbio.ac.cr) is cataloging Costa Rica's biodiversity, with emphasis on vascular plants and mosses (in collaboration with the Missouri Botanical Garden), insects and other invertebrates, and fungi and lichens (the latter in collaboration with The Field Museum, the New York Botanical Garden, and the Botanical Garden and Botanical Museum in Berlin-Dahlem, Germany). INBio has also been the driving force behind several large-scale projects to screen plants, fungi, and lichens for pharmaceutically active drugs (Joyce, 1992; Dalton, 2006). For the first time, tropical lichens were included in such a screening program, based on the TICOLICHEN project, through a collaborative endeavor between the National Institute of Biodiversity in Costa Rica (INBio), the Harvard Medical School, the University of Michigan, the Broad Institute, the Novartis Institutes for Biomedical Research, and The Field Museum (Dalton, 2006).

Because of the efforts of INBio, the National Museum, the University of Costa Rica, and their collaborating institutions, several organismic groups are now well known in Costa Rica in comparison with other tropical countries. A staggering 66,000 insect species, nearly $20 \%$ of the estimated total number, have been identified and/or described. More than 10,000 vascular plant species have been recorded for Costa Rica (Obando, 2002). The number of bryophytes amounts to 1275 (Bowers, 1974; Gradstein et al., 1994; Dauphin et al., 1998; Holz et al., 2001; Holz \& Gradstein, 2005; Gradstein \& Holz, 2005). In contrast, Fungi are the least known group besides bacteria and viruses, and of the 65,000 Fungi expected to occur in the country, only about 3500 are known to date (Obando, 2002; Lücking et al., 2004; Halling \& Mueller, 2005). This number is expected to raise dramatically because of the concerted effort of INBio, the Botanical Garden and Botanical Museum Berlin-Dahlem (Germany), the New York Botanical Garden, and The Field Museum to systematically explore the fungal and lichen biota of Costa Rica (Kappelle \& Sipman, 1992; Lücking 1992, 1995, 1999, 2003; Mueller \& Halling, 1995; Carranza \& Mueller, 1996; Gómez, 1996; Halling, 1996; Mata, 1999; Umaña \& Sipman, 2002; Huhndorf et al., 2003; Mata et al., 2003; Chaves et al., 2004; Fernández et al., 2004; Rogers et al., 2004; Halling \& Mueller, 
2005; Aptroot et al., 2006; Lücking et al., 2006, 2007a; Nelsen et al., 2006, 2007; Rivas Plata et al., 2006). Apart from INBio's specimen (http:// www.inbio.ac.cr/en/inbio/basicos.htm) and taxon databases (http://darnis.inbio.ac.cr/default. htm), several other searchable online databases on fungal and lichen collections and species from Costa Rica are now available, such as LICHCOL (http://www.bgbm.org/scripts/ASP/lichcol), the Catalog of Costa Rican Fungi (http://sciweb. nybg.org/science $2 / \mathrm{hcol} / \mathrm{cric} / \mathrm{crfungichecklist.asp)}$ at the New York Botanical Garden website, and The Field Museum's Costa Rican Fungi (http:// emuweb.fieldmuseum.org/botany/search_crf.php), all together with a total of more than 50,000 specimen records. Continuously growing species lists for macrofungi are available at the Macrofungi of Costa Rica project website (http://www. nybg.org/bsci/res/hall), and The Field Museum hosts the Preliminary Checklist of Lichens from Costa Rica (http://www.fieldmuseum.org/ticolichen/ checklist.html).

Even if the fungal and lichen biota of Costa Rica are insufficiently known, preliminary results indicate a high diversity that even exceeds the expectations in various groups. For example, in the lichen families and genera studied so far, the number of species is roughly twice as high as expected: foliose Physciaceae with about 100 species (Will-Wolf et al., in prep.), the genus Sticta with possibly 50 species (Lücking et al., in prep.), and the genus Graphis s.str., treated in the present work, with 115 species.

\section{Conservation}

Costa Rica has a long-standing tradition of protecting its natural resources as national parks and other types of protected areas. In recent years, the administration of these areas has undergone repeated changes. Since 1994, the protected areas are arranged in 11 conservation areas, which are individually administered under the National System of Conservation Areas or Sistema Nacional de Áreas de Conservación (SINAC; www.sinaccr.net), which forms part of the Ministry of Environment and Energy or Ministerio del Ambiente y Energía (MINAE; Www.minae.go.cr). SINAC oversees more than 160 protected areas, which together cover about $25 \%$ of the country's surface, including national parks (Parques Nacionales), biological reserves (Reservas Biológicas), wildlife refuges (Refugios de Fauna Silvestre), forest reserves (Reservas Forestales), protected zones (Zonas Protectoras), national wetlands (Humedales), and national monuments (Monumentos Nacionales).

Until the late 1980s, Costa Rica was considered one of the countries in the world with the highest deforestation rate, with only about $25 \%$ of forest left in 1987 (Fournier, 1985; Porras \& Villareal, 1985; García, 1997). Conservation efforts significantly increased during the 1980s, and the deforestation rate dramatically decreased from 60,000 ha per year in 1980 to presently less than 5000 ha per year (García, 1997; Obando, 2002). As a result, forest cover increased to presently almost $45 \%$, although most of the recovered areas were planted with fast-growing exotic trees, such as Eucalyptus, and only in part is the recovery due to natural forest regrowth.

Field observations and studies have shown that lichens can be used as bioindicators of ecological continuity of tropical forests (Wolseley \& Aguirre-Hudson, 1991; Wolseley et al., 1994; Rivas Plata et al., 2008). A study currently undertaken by Daniela Lizano from the University of Costa Rica, in the frame of the TICOLICHEN project, shows that lowland tree monocultures dramatically reduce beta diversity of epiphytic lichens when compared to undisturbed primary forest but are able to support a relatively high gamma diversity depending on the tree species used (Lizano et al., in prep.). Based on these findings, The Nature Conservancy and INBio are now studying the feasibility of using lichens as bioindicators to establish large-scale biological corridors between currently isolated, protected areas in the southern part of Costa Rica.

\section{Material and Methods}

The collections treated here were chiefly made in the frame of three TICOLICHEN field campaigns in the summer of 2002 , the spring of 2003, and the spring of 2004 but also during previous trips by the second author and from 2002 continuously by the third author. Identification work was done at the Adviesbureau voor Bryologie en Lichenologie in the Netherlands, at the Botanical Museum Berlin-Dahlem, at The Field Museum, and at the Fungal Laboratory of the National Biodiversity Institute in Costa Rica. At The Field Museum, specimens were examined using a LEICA MS 5 stereomicroscope and a 
TABLE 1. Definition and coding of four environmental parameters used for the multivariate analysis.

\begin{tabular}{ll}
\hline Category & Code \\
\hline Altitude & \\
Sea level & 1 \\
$0-200$ m (lowland) & 2 \\
$200-500$ m (submontane) & 3 \\
$500-1000$ m (lower montane) & 4 \\
$1000-1500$ m (montane) & 5 \\
$1500-2000$ m (montane) & 6 \\
$2000-2500$ m (upper montane) & 7 \\
$2500-3000$ m (upper montane) & 8 \\
$3000-3500$ m (subparamo) & 9 \\
Seasonality & 1 \\
No dry season & 2 \\
Slight dry season (<1 month) & 3 \\
Distinct dry season (1-3 months) & 4 \\
Strong dry season (3-5 months) & 5 \\
Extended dry season ( $>5$ months) & \\
Disturbance & 1 \\
Undisturbed forest & \\
Partly disturbed forest (selective & 2 \\
$\quad$ logging) & \\
Old growth secondary forest $(>25$ & 3 \\
$\quad$ years) & \\
Young secondary forest (<25 years) & 4 \\
Anthropogenic vegetation (plantations, & 5 \\
$\quad$ gardens) & \\
Exposure & \\
Fully shaded (0-2\% diffuse site factor) & 1 \\
Shaded (2-5\% diffuse site factor) & \\
Semiexposed (5-13\% diffuse site factor) & 3 \\
Exposed (13-35\% diffuse site factor) & \\
Fully exposed (35-100\% diffuse site & \\
$\quad$ factor) & \\
\hline & \\
& \\
\hline
\end{tabular}

ZEISS Axioscop 2 compound microscope connected to a DAGE MTI DC-330 3CCD color camera. Images were also made with a NIKON F301 SLR camera and a NIKON Coolpix 5400 digital camera.

For the ecological analysis, 803 samples of Graphis from the TICOLICHEN database were selected, representing 90 species; species reported here but based on previous or historic collections were not included in the analysis because of the lack of detailed ecological data. For each sample, four environmental parameters were scored: altitude, seasonality, exposure, and disturbance (Table 1). For each species, samples were then combined to compute weighted average scores by species, and species were subsequently assigned to taxonomic groups: scripta gr., farinulenta aggr., glaucescens aggr., insulana gr., duplicata gr., proserpens aggr., caribica aggr., rhizocola gr., nuda gr., acharii gr., and cinerea aggr.
The data matrix (90 species by four environmental variables) was subjected to principal component analysis (PCA) using the software PC-ORD 5.03 (McCune \& Mefford, 1999) and to analysis of variance (ANOVA) using the software Statistica 6.0. PCA is an ordination method that projects multivariate relationships between species or sample scores into a two-dimensional plane. When ordinating species or samples based on species abundances within samples, this method performs poorly since the requirement of linear correlation between species scores and sample scores is usually not fulfilled (McCune et al., 2002). However, the use of environmental scores per species computed as weighted average scores circumvents this problem and makes PCA the best method to ordinate such data.

\section{The Lichen Family Graphidaceae and the Genus Graphis}

\section{General Remarks}

Both in terms of diversity and abundance, the family Graphidaceae is the dominant element among lichen communities in tropical ecosystems (Wirth \& Hale, 1963, 1978; Patwardhan \& Kulkarni, 1976, 1977, 1979a,b; Patwardhan \& Nagarkar, 1979; Sipman \& Harris, 1989; Archer, 1999, 2000, 2001a-e, 2003a,b, 2005, 2006; Staiger, 2002; Makhija \& Adawadkar, 2005a,b; Makhija et al., 2005; Lücking et al., 2008b). In our ongoing TICOLICHEN biodiversity survey, we have assembled and databased some 30,000 new collections, and of these, roughly $15 \%$ are Graphidaceae. Excluding upper montane and paramo regions, the proportion of Graphidaceae approaches almost 30\%. Our preliminary taxonomic assessment indicates that Graphidaceae make up some $7 \%$ of all lichen species expected to occur in Costa Rica, surpassed only by macrolichens in the Parmeliaceae.

Until most recently, the bulk of Graphidaceae was divided into the genera Graphis, Graphina, Phaeographis, and Phaeographina, depending on whether the ascospores are transversely septate or muriform, colorless or grayish brown. Most workers considered this concept as highly artificial (Wirth \& Hale, 1963, 1978; Harris, 1990, 1995); for example, variation of ascospore septation in the Graphis chrysocarpa complex justified its alternative placement in either 
Graphis, Graphina, or Phaeographina (Wirth \& Hale, 1963). Recent revisions of Acanthothecis and Dyplolabia (Staiger \& Kalb, 1999; Kalb \& Staiger, 2000) set the stage for a more natural approach, but it was not until recently that Staiger's seminal thesis on generic delimitation in Graphidaceae (Staiger, 2002) cut the gordian knot. Instead of ascospore septation, a set of characters, such as excipulum and hamathecium structure, ascospore color and iodine reaction, and chemistry, is now used to achieve a much more satisfying genus concept. Molecular phylogenetic approaches largely support this concept (Kalb et al., 2004; Staiger \& Grube, 2004; Staiger et al., 2006; Mangold et al., 2008), which was widely accepted (Nakanishi et al., 2003; Archer, 2006). Including the recent revision of Diorygma (Kalb et al., 2004), which synonymizes Cyclographina, Glaucinaria, and Solenographa with the latter, 24 graphidoid genera are now being distinguished (Table 2; Aptroot \& Sipman, 2007; Lücking \& Rivas Plata, 2008). Most of these seem to be natural, well-distinguished groups, but more molecular data are necessary to confirm or further modify this concept.

Hemithecium falls into two entities, Hemithecium s.str. and subgen. Leucogramma, the first closely related to (or nested within?) Graplis and the second related to Phaeographis and allied genera (Staiger, 2002; Staiger et al., 2006). Hemithecium subgen. Leucogramma was newly established by Staiger (2002), but also the generic name Leucogramma A. Massal. exists and is based on the same species as Staiger's subgenus, Hemithecium chrysenteron. Unfortunately, both names are unavailable at the genus level since they are homonymous with Leucogramma G. Mey., a name of unknown taxonomic affinity (Staiger, 2006). As a consequence, if Hemithecium subgen. Leucogramma Staiger is recognized at genus level, a replacement name must be introduced for Leucogramma A. Massal., comprising three species:

Pallidogramme Staiger, Kalb \& Lücking, nom. nov. Bas. Leucogramma A. Massal. Holotype. Pallidogramme chrysenteron (Mont.) Staiger, Kalb \& Lücking. = Hemithecium subgen. Leucogramma Staiger.

Pallidogramme chapadana (Redinger) Staiger, Kalb \& Lücking, comb. nov. Bas. Phaeographina claapadana Redinger, Ark. Bot. 26A(1): 100. 1933; Hemithlecium chapadanum (Redinger) Staiger, Bibl. Lichenol. 85: 281. 2002.
Lectotype (fide Staiger, 2002: 281). Brazil, Malme 3507 (s!).

Pallidogramme chlorocarpoides (Nyl.) Staiger, Kalb \& Lücking, comb. nov. Bas. Graphis chlorocarpoides Nyl., Flora 49: 133. 1866; Phaeographina chlorocarpoides (Nyl.) Zahlbr., Cat. Lich. Univ. 2: 435. 1923; Hemithecium chlorocarpoides (Nyl.) Staiger, Bibl. Lichenol. 85: 283. 2002. Holotype. Indonesia (Java), Kurz s.n. (H-Nyl 6898!).

Pallidogramme chrysenteron (Mont.) Staiger, Kalb \& Lücking, comb. nov. Bas. Graphis chrysenteron Mont., Ann. Sci. Nat. Bot. 18: 270. 1842; Leucogranma chrysenteron (Mont.) A. Massal., Atti Reale Ist. Veneto Sci. Lett. Arti, Ser. 3, 5: 320. 1860; Phaeographina chrysentera (Mont.) Müll. Arg., Hedwigia 30: 52. 1891; Hemithecium chrysenteron (Mont.) Trevis., Spighe e Paglie 1: 13. 1853. Holotype. Guyana, Leprieur 23 (PC, not seen).

\section{Taxonomy of the Genus Graphis}

Since species of Graphis were traditionally characterized by transversely septate, hyaline ascospores, the delimitation of species concentrated on features of the excipulum, ascospore size and number of septa, and secondary chemistry (Wirth \& Hale, 1963, 1978; Patwardhan \& Kularni, 1976, 1977, 1979a,b; Patwardhan \& Nagarkar, 1979; Archer, 1999, 2000, 2001a-e, 2003a,b). The revised circumscription of the genus as defined by Staiger (2002) requires a new approach toward species delimitations and reevaluation of a whole set of characters for taxonomic purposes. Since a separate paper (Lücking 2008b) deals with these issues in great detail, we present here only a short discussion on the characters used to distinguish species and species groups.

Thallus Morphology-Almost all species of Graphis have a corticate, white to pale gray thallus incrusted with calcium oxalate crystals. The thallus color is different from most other genera, especially Glyphis and those genera with gray-brown ascospores and inspersed hymenium (Phaeographis and relatives), which typically have a yellow-green to olive-brown thallus. Such a thallus color has only been found in two species of Graphis here, G. caribica and G. foumierii. A few species of Graphis have a cortex that flakes off or are completely ecorticate and then more or 


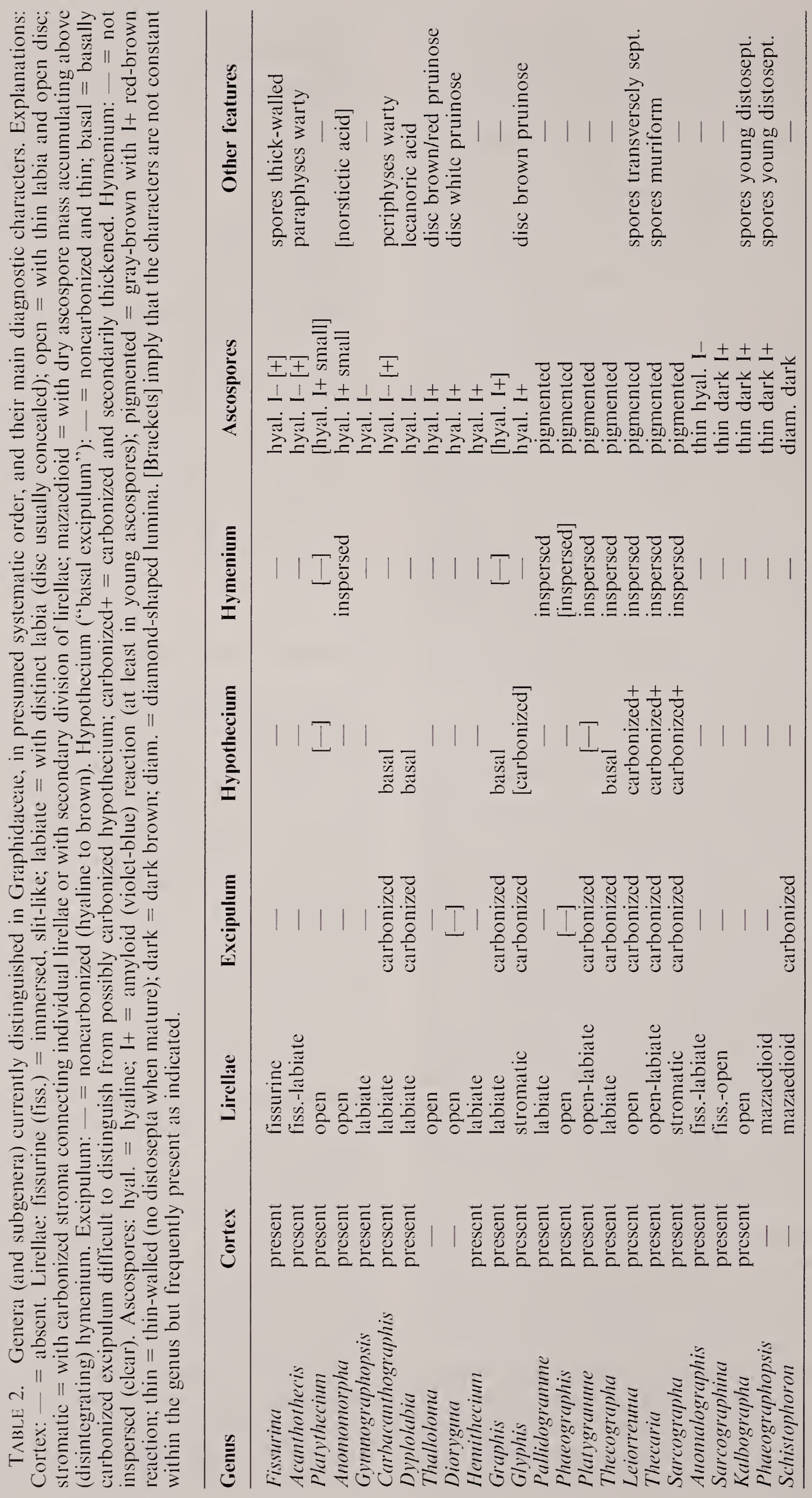


less farinose. This feature is species specific and even seems to characterize certain natural groups, such as the $G$. glaucescens and $G$. farinulenta aggregates. Species of Graphis almost exclusively grow on bark, but foliicolous specimens occasionally occur that are otherwise similar to corticolous collections. Saxicolous specimens are also rare, and in at least two instances, $G$. carassensis and G. myrtacea, they are conspecific with corticolous collections. Thus, substrate preference alone cannot be used as a taxonomic character.

LiRELlAE MORPHOLOGY-The morphology of the lirellae has only rarely been used as taxonomic feature, probably because previously a much larger variety of lirellae types was included in the genus which are now placed elsewhere (Anomomorpha, Diorygma, Hemithecium, Platythecium, Thalloloma), and so the morphological variation in Graphis s.str. was not taken that much into account. However, Staiger's (2002) monograph and a phenotypebased phylogenetic study of the genus (Lücking, 2008b) showed that lirellae morphology is the most important character complex for delimiting not only species but even natural groups within Graphis s.str. (Fig. 3). Although varying to a certain extent, the length of the lirellae and their branching pattern is usually species specific, as shown by correlation with other characters in our collections and also reported for other Graphidaceae (e.g., Ernst \& Hauck, 1994; Archer, 2006). Very short, unbranched lirellae are typical of the Graphis nuda group (Fig. 3G) and the G. plagiocarpa and $G$. triphora aggregates, and perfectly round lirellae are found in the G. globosa aggregate (Fig. $3 \mathrm{H}$ ). On the other hand, strongly elongate, radiately lirellae (Fig. 3D) are typical of species such as $G$. dendrogramma and $G$. dichotoma and relatives. Species in the G. scripta group typically have short, sparsely branched, boat-shaped lirellae (Fig. 3A). Another important, species-specific character is the degree of immersion of the lirellae and their thallus cover (Fig. 4). Most members of the G. scripta group have immersed to erumpent lirellae with a distinct lateral thalline margin that exposes the upper, black part of the labia. Species in the G. acharii and G. rhizocola group usually have prominent to sessile lirellae with (apically often thin) complete thalline cover, and the upper part of the labia then appears dark gray to almost white (Fig. 3E-F). Graphis nuda and its relatives resemble species of Melaspilea because of their short, sessile, black lirellae completely lacking a thalline margin (Fig. 3G). Graphis plagiocarpa and its relatives in the $G$. dussii aggregate are similar but feature a very thick lateral thalline margin. Correlation with anatomical features shows that these characters vary little within a given species and can usually be used to predict ascospore type and other anatomical features. A few species of Graphis, all in the G. scripta group, show an exposed disc (Fig. 3B), and this character has been used to separate species. In general, most species of Graphis have the disc more or less exposed when hydrated, but in the dry state the disc is usually concealed. The fact that open discs in the dry state occur only in the G. scripta group underlines the taxonomic importance of this feature.

LiREllae Pruina-Several species of Graphis exhibit pruinose labia (Fig. 3C) or discs (when exposed). Variation of this character is little understood, but most of the material available indicates that this feature is species specific. A thin pruina is usually composed of a layer of crystals and dead hyphal material, whereas the thick pruina characteristic of Carbacanthographis and Dyplolabia species and composed of a layer of hyphae inspersed with crystals or pigment (Staiger, 2002) is very rare in Graphis. Only in a few cases here, species were separated exclusively by the presence or absence of pruina on the labia or disc, and these cases have to be studied further. The most well known is $G$. scripta itself, which includes both pruinose and nonpruinose forms, but it is unclear whether $G$. scripta represents only a single species or a species complex.

LABIA STRIATION-This character has been used as an important taxonomic feature in the past (Wirth \& Hale, 1963, 1978) and was also taken up by Staiger (2002). However, since labia striation seems to be connected to the formation of new hymenia (Staiger, 2002), it could be suspected that entire versus striate labia represent developmental stages of the same species rather than a taxonomically important character. In the present material, we have indeed found several examples where the transition from entire to striate labia could be observed on a single thallus, and we have opted not to distinguish between species on the base of entire versus striate labia alone. However, there are many taxa in which a striate "labiomorph" (i.e., a form being identical in all characters except for entire 

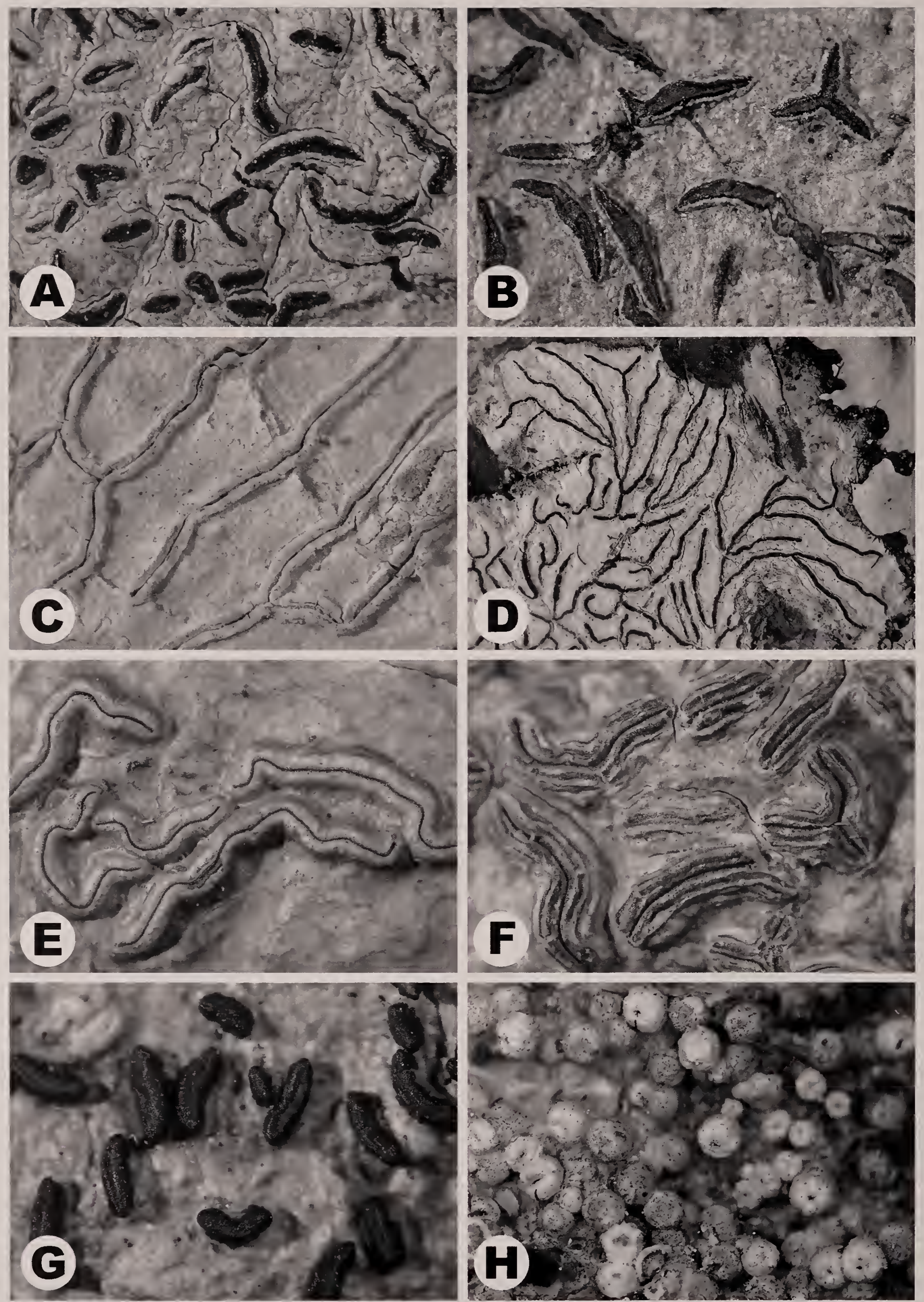

FIG. 3. Lirellae morphology in the genus Graphis. (A) Erumpent with lateral thalline margin (G. librata). (B) Erumpent with lateral thalline margin and exposed disc $(G$. chondroplaca). (C) Erumpent with pruinose labia $(G$. glaucescens). (D) Immersed with lateral thalline margin and radiate branching $(G$. dichotoma). (E) Prominent with complete thalline cover $(G$. rhizocola). (F) Prominent with complete thalline cover and striate labia $(G$. argentata). $(\mathbf{G})$ Sessile lacking thalline margin, Melaspilea-like (G. adpressa). (H) Sessile with complete thalline cover, round (G. mexicana). 


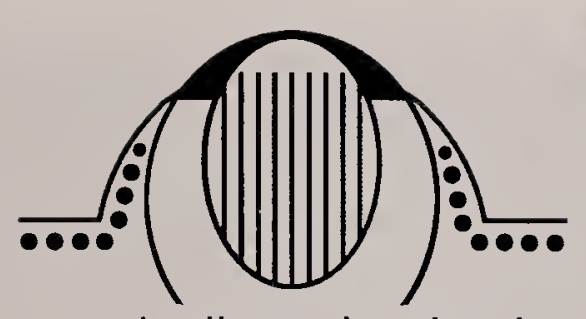

apically carbonized

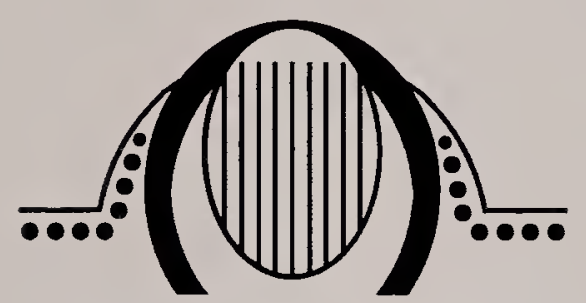

peripherically carbonized

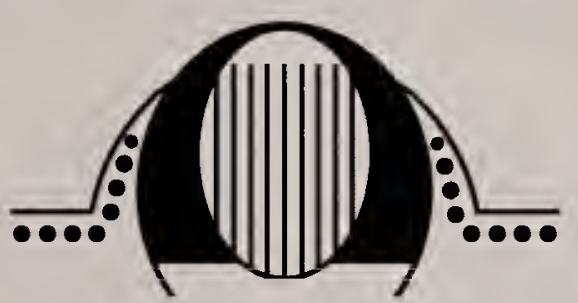

laterally carbonized

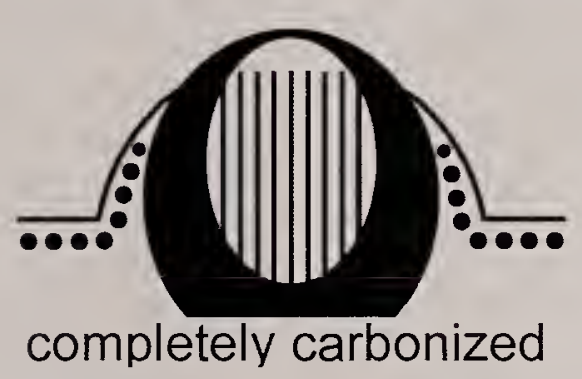

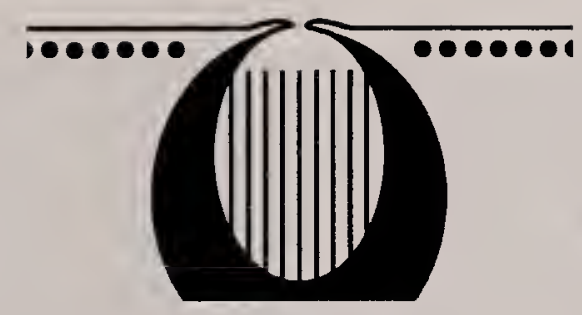

immersed

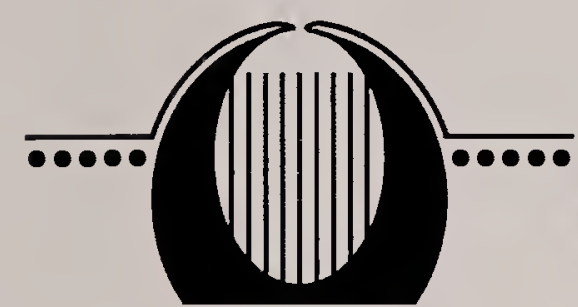

erumpent

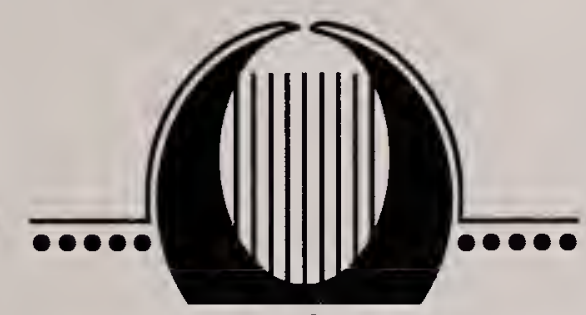

prominent

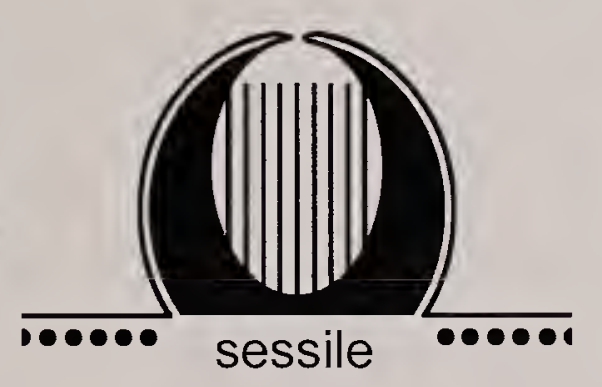

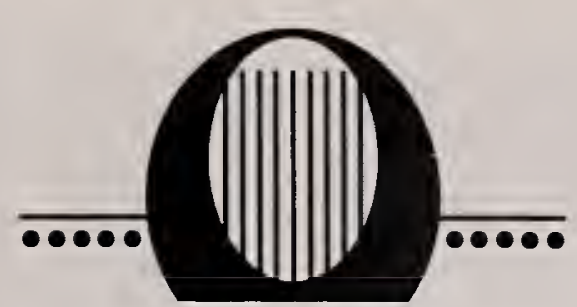

lacking thalline margin

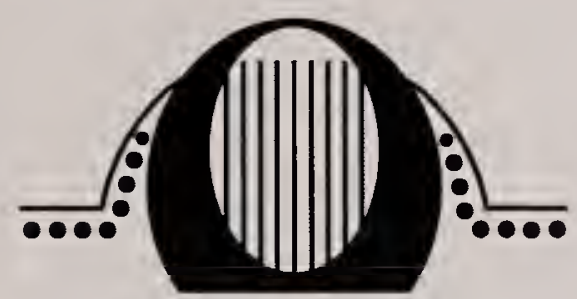

lateral thalline margin

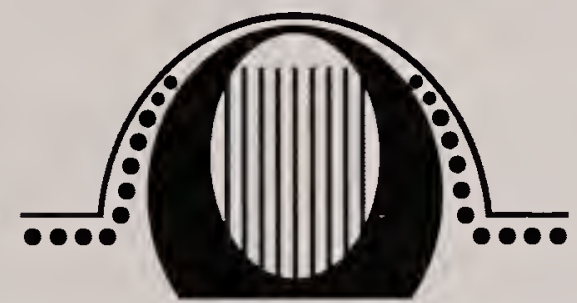

thin complete thalline cover

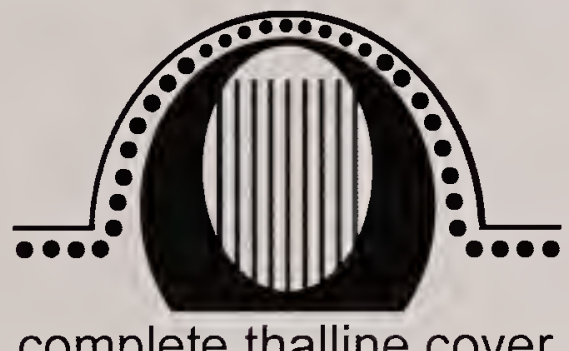

FIG. 4. Schematic representation of excipular carbonization and lirellae morphotypes in the genus Graphis.

versus striate labia) is unknown; that is, they either never form new hymenia or have other strategies to produce new ascospores each year. Also, there are many taxa in which nonstriate counterparts are unknown and in which even the young lirellae at the thallus margin are already striate. Thus, certain species groups, such as the G. duplicata group (elongate, mostly prominent lirellae mostly lacking thalline margin) and the $G$. acharii group (elongate, prominent to sessile lirellae with complete thalline cover), are characterized by species with mostly to exclusively striate labia (entire only in the first-generation lirellae). Others, such as the G. rhizocola group (rounded to elongate, prominent to sessile lirellae with complete thalline cover and thin paraphyses) and the G. nuda group (short, sessile lirellae lacking thalline cover), typically have entire labia. In conclusion, while labia striation alone cannot be used to distinguish species, this character is of taxonomic and systematic value, as already pointed out by Staiger (2002) and previous authors. It should also be pointed out that not all cases of striation are due to the formation of new hymenia. In some cases, such as in the G. rhizocola group, usually nonstriate species sometimes show finely or indistinctly striate labia, but when sectioned, this striation is restricted to the surface of the otherwise massive excipulum and clearly not associated with remnants of old hymenia. Such labia are here called pseudostriate.

EXCIPULUM CARBONIZATION-The genus Graphis is characterized by a partially to completely carbonized excipulum, and this feature varies according to species (Fig. 4). Following previous workers (Wirth \& Hale, 1963, 1978), Staiger (2002) distinguishes several groups within the genus that are characterized by their degree of excipulum carbonization and by the presence or absence of striation. Our experience with the present material and hundreds of types, as well as a phenotype-based cladistic analysis (Lücking, $2008 \mathrm{~b}$ ), shows that the degree of variation in excipulum carbonization and striation within natural groups is greater than previously assumed and that lirellae morphology is more important in delimiting these groups. Thus, in the $G$. scripta, $G$. insulana, and $G$. duplicata groups, closely related species can have either apically, laterally, or completely carbonized excipula, and in the $G$. duplicata group, many species have apically carbonized excipula only, while others have the excipulum completely carbonized. Especially within the $G$. duplicata group, this feature sometimes varies even within 

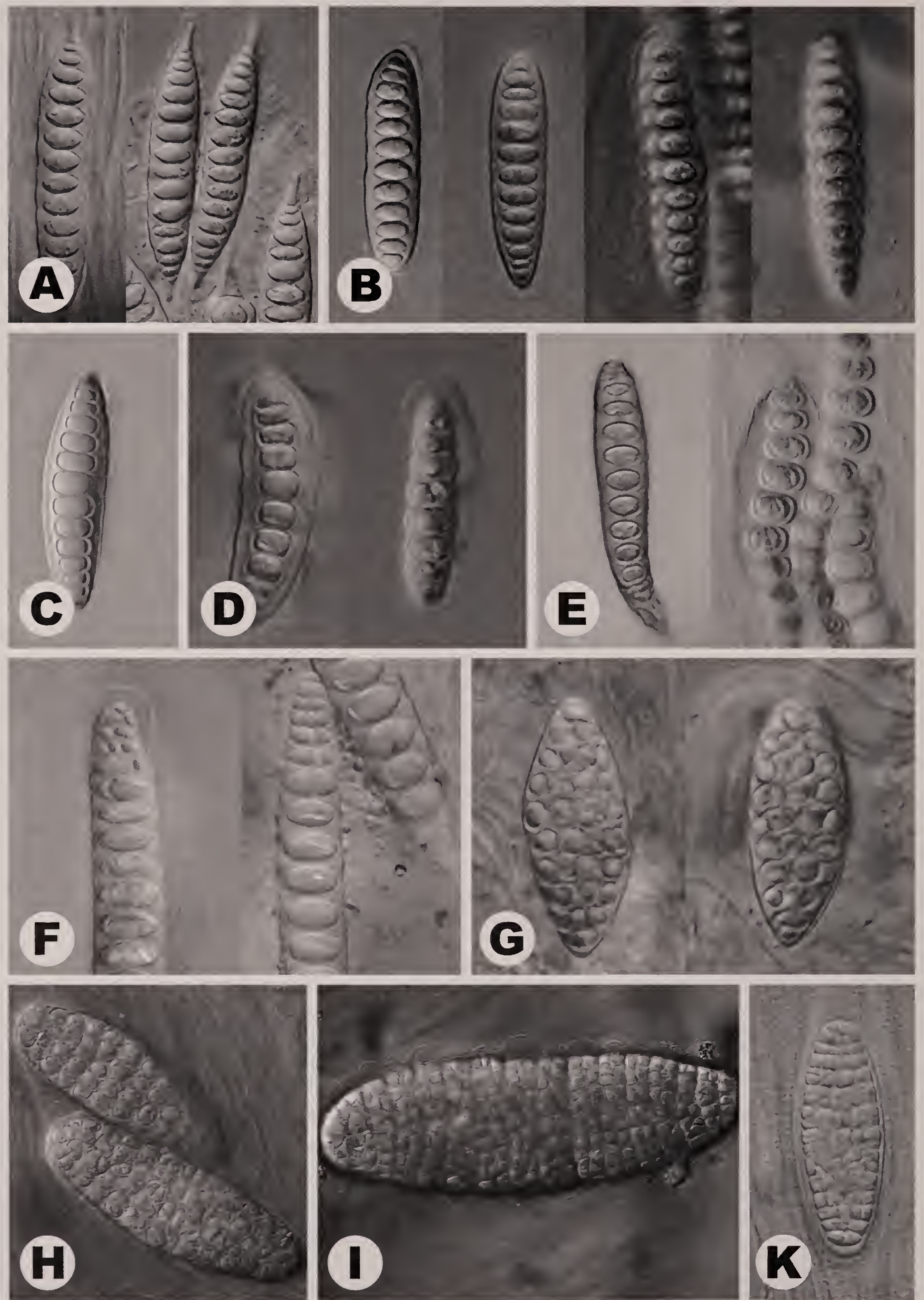

FIG. 5. Ascospore types in the genus Graphis. (A) Graphis rhizocola (note the shortly tailed ends). (B) Graphis ovata (ascospores to the right in $\mathrm{KOH}$, note the change in lumina and wall structure). (C) Graphis adpressa (note the thick outer wall and oval lumina). (D) Graphis elegans (note the thick outer wall and oval lumina; ascospores to the right in $\mathrm{KOH}$, note the change in lumina and wall structure). (E) Graphis pittieri (ascospores to the right in $\mathrm{KOH}$, note the change in lumina and wall structure). (F) Graphis vestitoides (note the terminally muriform 
a single taxon, and certain species complexes, such as G. striatula, G. rimulosa, and G. tenella, need further study as to whether forms with laterally versus apically or completely carbonized excipula ("excipulomorphs") really represent different species. Archer (2006) recently synonymized $G$. subtenella Müll. Arg. (= G. chlorotica A. Massal.) with $G$. tenella Ach., supposedly based on lack of difference in striation, but the main difference between the two species is the apically versus laterally carbonized excipulum, which in our material was constantly separating the two taxa. The $G$. acharii and G. rhizocola groups, on the other hand, are rather constant in having a basally thick and closed, completely carbonized excipulum. It is not yet well understood whether the basal, carbonized excipulum in Graphis is homologous with the excipulum in other genera or, at least in part, represents a carbonized hypothecium, as in Leiorreuma, Sarcographa, and Thecaria (Staiger, 2002). Also, the taxonomic importance of the presence of a basal excipulum, whether carbonized or not, needs further study.

HYMENIUM INSPERSION-Hymenium inspersion is another character that was rarely used in the taxonomy of Graphis species but turned out to be relevant at the species level (Staiger, 2002). The importance of this character is underlined by the fact that two different types of inspersion occur within the genus and that these types are largely restricted to three species groups. Several species in the G. scripta group and the related $G$. insulana group have their hymenia inspersed with regularly scattered oil droplets that more or less persist in $\mathrm{KOH}$ but do not obstruct the view of asci and ascospores (type A). The G. acharii group, on the other hand, contains a number of species, here delimited as $G$. cinerea aggregate, that have a very strong and dense hymenial inspersion completely obstructing the view of asci and ascospores but easily dissolving in $\mathrm{KOH}$ (type B). In both cases, forms that are otherwise identical but differ in the presence or absence of hymenial inspersion ("inspersomorphs") are here regarded as distinct species.

PARAPHYSES-Species of Graphis feature two paraphysis types: (1) rather thick $(1.5-2 \mu \mathrm{m})$, often slightly articulate, apically brownish paraphyses in most species versus (2) thinner (1$1.5 \mu \mathrm{m})$, filiform, apically unpigmented paraphyses in many species of the $G$. carassensis group, here named G. rhizocola group (Staiger, 2002). Whether this character is sufficient to separate the latter at the genus level remains to be studied, but in our experience, the differences are slim, and intermediate forms are not uncommon in the genus, as also admitted by Staiger (2002). Molecular evidence does not support this differentiation: species of the $G$. acharii group ( $G$. chrysocarpa, G. cinerea), which have paraphyses of type (1), and species of the G. carassensis group sensu Staiger (G. ruiziana), with paraphyses of type (2), fall onto the same clade (Staiger et al., 2006).

ASCOSPORE TYPE-Species of Graphis typically have hyaline, I+ violet-blue, distoseptate ascospores with lens-shaped lumina (Fig. 5). The iodine reaction is concentrated in the endospore and usually very strong, giving a violet-blue to violet-brown color that often obscures the septa in mature ascospores (Staiger, 2002), except at the tips, where the lumina tend to be smaller with less endospore (looking juvenile). In a few species, especially in the $G$. acharii group ( $G$. chrysocarpa, $G$. vestitoides), the ascospores become slightly gray-brown but not as dark as in Phaeographis and related species. The only exception is $G$. pittieri, which has distinctly gray-brown ascospores when mature (Fig. 5E) but otherwise fits well into the G. nuda group. Many species feature a gelatinous sheath or caps (Fig. 5F), but this character has been little explored and might also depend on the age of the specimen and how it was preserved. Unusually thick, finally pale gray-brown ascospore walls combined with oval rather than lensshaped lumina are found in G. elegans (Fig. 5D) and, to a lesser degree, in G. lumbricina, and one might be inclined to accept this species in a separate genus (the name Aulacographa being available). However, similar ascospores are also found in a few other, seemingly unrelated species, such as G. adpressa (Fig. 5C). Application of $\mathrm{KOH}$ indicates that there are actually two ascospore walls with different consistence in all

septation and apical gelatinous cap). (G) Graphis ruiziana (note the rounded lumina). (H) Graphis subruiziana (note the rounded lumina). (I) Graphis myrtacea (note the reduced endospore and almost angular lumina). (K) Graphis insulana (note the lack of endospore and angular lumina, as well as the inspersed hymenium). 
species of Graphis, and the development of the outer wall is variable. This can be seen when comparing the ascospores of $G$. ovata (lensshaped lumina), G. pittieri (lens-shaped lumina, gray-brown) and $G$. elegans (thick-walled with oval lumina): after application of $\mathrm{KOH}$, they all look similar, with thin inner walls, oval lumina, and strong constrictions at the septa (Fig. 5B, D, E). Other variation is found in the degree of the endospore thickenings, especially in taxa with muriform ascospores. While in many species with muriform ascospores, such as $G$. ruiziana and $G$. subruiziana (Fig. $5 \mathrm{G}-\mathrm{H}$ ), the endospore thickenings are well developed and the lumina rounded, in others, such as G. myrtacea and $G$. insulana (Fig. 5I-K), they are reduced to completely absent, and the lumina appear angular. A particular type of ascospores is found in $G$. vestitoides (Fig. 5F) and a few other species, mostly in the G. acharii group (e.g., G. subchrysocarpa): the ascospores are transversely septate in the middle but muriform at both ends (sometimes called "biocellate" in the literature; Wirth \& Hale, 1978). Correlation with other characters, as well as examination of ascospore ontogeny in species with muriform ascospores (which do not feature a terminally muriform stage), show that these terminally muriform ascospores do not represent an ontogenetic stage but are a species-specific feature.

For proper interpretation of ascospore characters, care should be taken to exclude taxonomically uninformative, infraspecific and ontogenetic variation. In correlation with the final number of ascospores per ascus, ascospore size is variable and the entire size range of ascospores should be observed. In species with usually eightspored asci, two- to six-spored asci sometimes occur in the same hymenium, and then the ascospores will be larger than the usual size range. In specimens with few ascospores, these may represent atypical, even deformed leftovers. Relevant characters change during ascospore development, and it is at times difficult to decide which is the proper stage for observation. The endospore development is a good indicator. Mature ascospores 'usually have a thick layer along the septa, causing a heavy iodine staining. In young ascospores, the endospore is thinner and the iodine reaction weak to zero. Also, mature ascospores are often (slightly) constricted at the septa, while young ascospores are not. In old, postmature ascospores, the endospore disintegrates, the iodine reaction disappears, and often the ascospores shrivel. An exception is the characteristic pale gray-brown color of the $G$. elegans-type ascospores, which seems to develop in mature ascospores with well-developed endospore.

Ascospore size and its taxonomic relevance is a particularly difficult character in Graphis and other genera of Graphidaceae. Based on the study of individual thalli, as well as size variation in well-delimited species, such as $G$. chrysocarpa s.str., we have generally accepted a size range of about $100 \%$, that is, the upper limit being about twice as large as the lower limit (e.g., 25-50 $\mu \mathrm{m}$, 50-100 $\mu \mathrm{m}, 100-200 \mu \mathrm{m}$, and so on). Even so, delimitation of species based on this range might be too narrow since recent studies suggest that intraspecific ascospore size variation might be even greater, with the upper limit up to three times as large (Pentecost, 2003). However, without independent evidence, such as molecular data, it is rather difficult to prove whether ascospore size variation is indeed intraspecific or indicates separate microspecies.

Species with otherwise identical characters but different ascospores occur frequently in Graphis, and we have adopted the term "sporomorph," coined by Wirth and Hale (1978), for such taxa. In analogy, we use here the terms "labiomorph," "excipulomorph," "inspersomorph," and "chemomorph" for species pairs or aggregates, or forms, that differ in a single character complex.

SECONDARY CHEMISTRY-Most species of Graphis s.str. lack secondary substances (Staiger, 2002; Archer, 2006). Species with a simple chemistry with norstictic or stictic satellite acids are particularly common in the G. scripta and the related $G$. insulana group. Salazinic and protocetraric acids do occur as well but are relatively rare. A few species have a combination of up to three of these acids, such as the newly described $G$. litoralis. Lichexanthone is found in less than a handful of taxa ( $G$. haleana, $G$. lucifica, $G$. sauroidea). Yellow to orange anthraquinones are restricted to a few species in the G. rhizocola and $G$. acharii groups and usually occur as pruina on the surface of the labia. Isohypocrellin, a dark red, $\mathrm{K}+$ green anthraquinone widespread within the family, is so far found in only two species of Graphis, with one being here described from Costa Rica, G. hypocrellina ( $G$. duplicata group). Several workers have discussed the usefulness of secondary chemistry to distinguish species (Harris, 1995; Staiger, 2002), often assuming infraspecific variation with respect to 
absence or presence of substances such as norstictic acid, stictic acid, or lichexanthone. However, there is a clear correlation between certain species groups and the presence and abundance of certain substances, emphasizing their taxonomic value. Many species that are well characterized by morphological and anatomical characters, such as G. chrysocarpa, $G$. elegans, and $G$. lumbricina, show a uniform secondary chemistry.

INFRAGENERIC SUBDIVISION-Even with the revised definition provided by Staiger (2002), Graphis continues to be the largest genus in the family, with probably more than 300 species, and it is tempting to split this genus into smaller entities. However, although certain natural groups can be distinguished within Graphis, these groups strongly intergrade, and placement of certain species within one of these groups would be arbitrary at this point. Interestingly, in molecular analyses, species of Graphis fall onto two different clades, a phenomenon difficult to explain at this point since the two clades do not correlate well with morphoanatomical characters (Staiger et al., 2006; Mangold et al., 2008): one clade correlates largely with the G. scripta group but also includes one species of the $G$. dussii aggregate in the G. rhizocola group, whereas the other clade comprises two species of the $G$. acharii group, one of the $G$. nuda group, and one of the $G$. farinulenta aggregate in the G. scripta group. Here we distinguish several groups and aggregates nested within these groups, expanding from Staiger's (2002) treatment and judging from a phenotype-based cladistic analysis (Lücking, 2008b):

Graphis scripta Group-Species of this group typically have delicate lirellae that are immersed to erumpent and often feature a lateral thalline margin (Fig. 3A). The excipulum is mostly laterally carbonized and basally open, but species with apically or completely carbonized excipulum do occur. Species with exposed disc are not rare (Fig. 3B). Hymenial inspersion of type $\mathrm{A}$ is common, as is the presence of secondary substances (norstictic and stictic acids and relatives). Ascospores are transversely septate to muriform and small to medium sized (usually less than $60 \mu \mathrm{m}$ long). Several species have strongly elongate, slender, radiating lirellae (Fig. 3D).

Graphis farinulenta Aggregate-This aggregate is characterized by more prominent lirellae with thin white pruina and often (partially) ecorticate thallus. Ascospores are transversely septate and small to medium sized. This is probably a monophyletic aggregate of sporomorphs nested within the G. scripta group, although molecular analysis (Staiger et al., 2006) suggests a closer relationship with the $G$. acharii group. One species in this aggregate, G. seminuda, is very similar to species in the G. rhizocola group.

Graphis glaucescens Aggregate-This is also part of the Graphis scripta group but differs in the strongly pruinose labia (Fig. 3C), ecorticate, farinose thallus, and often apically carbonized excipulum. Superficially the species resemble those of Diorygma, but that genus differs in anatomical and chemical characters.

Graphis insulana Group-This group agrees with the Graphis scripta group in many characters (lirellae morphology and anatomy, type A inspersion common, chemistry) but differs in the large, often muriform ascospores and the large, robust lirellae, often completely covered by a thalline layer. Intermediate forms are rare.

Graphis oxyclada Group-This group is somewhat intermediate between the Graphis scripta group and the G. rhizocola group. It is characterized by a completely carbonized excipulum, small to medium-sized ascospores, and black lirellae as in the G. scripta group, but the lirellae are prominent and often very long like those in the G. rhizocola group.

Graphis rhizocola Group-Species of this group are characterized by robust, prominent to sessile lirellae that often are completely covered by a thalline layer (Fig. 3E). The excipulum is typically completely carbonized and massive, compressing the hymenium to a narrow space. Striation is rare and if present, often indistinct. Inspersion is extremely rare (so far only one species known), and secondary substances are absent in many species. Ascospores are transversely septate to muriform and large to very large, usually more than $80 \mu \mathrm{m}$ and up to $300 \mu \mathrm{m}$ long. Staiger (2002) reported relatively narrow paraphyses for this group, but this feature does not seem to be consistent, and the differences with other groups are slim and not supported by molecular data (see above). Graphis rhizocola and related species often have a shiny, smooth, gray-green thallus differing from the white, uneven thallus typical of other Graphis species. Lirellae morphology varies from strongly elongate (Fig. 3E) to round (Fig. 3H). The $G$. rhizocola group includes some smaller aggregates with remarkably uniform lirellae morphology: the G. globosa aggregate (lirellae round, perithe- 
TABLE 3. List of species of Graphis reported and accepted from Costa Rica.

1. Graphis acharii Fée

$=$ Graphis curta Fée

= Graphina tuberculifera Müll. Arg.

= Graphina pachypleura Müll. Arg.

2. Graphis adpressa Vain.

3. Graphis altamirensis Sipman \& Lücking, sp. nov.

4. Graphis anfractuosa (Eschw.) Eschw.

5. Graphis angustata Eschw.

= ?Graphis subcurva Zenk.

$=$ Graphis flexibilis Kremp.

= Graphis subanglistata Vain.

6. Graphis antillarum Vain.

= Graphis platycarpoides Vain.

7. Graphis aquilonia (Archer) Staiger

8. Graphis argentata Lücking \& Umaña, sp. nov. $=$ Graphis cinereoides Lücking \& Chaves [nom. inval.]

9. Graphis bettinae Lücking, Umaña, Chaves \& Sipman, sp. nov.

10. Graphis bipartita (Müll. Arg.) Lücking, comb. nov. = Graphis peralbida Nyl.

11. Graphis caesiella Vain.

12. Graphis caesiocarpa Redinger

13. Graphis carassensis Vain.

14. Graphis caribica Lücking

15. Graphis chlorotica A. Massal. $=$ Graphis subtenella Müll. Arg.

= Graphis duplicata var. australasiatica Vain.

16. Graphis chondroplaca (Redinger) Lücking, comb. et stat. nov.

$=$ Schistostoma dehiscens Stirt.

$=$ ? Graphis guimarana Vain.

17. Graphis chrysocarpa (Raddi) Spreng.

= Graphis ignea Kremp.

$=$ ? Graphis kermesina Fée

$=$ ? Graphis rubricosa Fée

18. Graphis cinerea Fée

19. Graphis cleistoblephara Nyl.

= Graphis subpulicaris Zahlbr.

20. Graphis consanguinea (Müll. Arg.) Lücking, comb. nov.

= Graphis includens Vain.

= Graphis pseudosophistica Vain.

= Graphina heteroplacoides Redinger

= Graphina nylanderiana Zahlbr.

21. Graphis dendrogranma Nyl.

= Graphis irradians Nyl.

= Graphis ceylandica Zahlbr.

= Graphis bougainvillei Zahlbr.

= Graphis batanensis Vain.

= Graphis subvirginea var. streblicola Vain.

= Graphis subvirginea var. rhizophorearum Vain.

22. Graphis dimidiata Vain.

23. Graphis disserpens Nyl.

24. Graphis dracenae Vain.

= Graphis leptocarpa var. invita Vain.

= Graphis immersicans A. W. Archer

25. Graphis dupaxana Vain.

= Graphis moultonii Vain.

26. Graphis duplicata Ach.

= Graphis schizograpta Müll. Arg.

= Graphis lopingensis Zahlbr.

= Graphis hussuensis Zahlbr.
= Graphis bicrenulata Redinger

27. Graphis duplicatoinspersa Lücking, sp. nov.

28. Graphis elegans (Sm.) Ach.

29. Graphis dichotoma (Müll. Arg.) Lücking, comb. nov. $=$ Graphina elongatoradians Fink

30. Graphis emersa Müll. Arg.

31. Graphis farinulenta Müll. Arg.

32. Graphis firferi Lücking, sp. nov.

33. Graphis flavens Müll. Arg.

= Graphis angustata var. denudata Vain.

= Graphis subintegra Redinger

= Graphis atrolabiata Chaves \& Lücking, nom. inval.

34. Graphis flavoaltamivensis Sipman \& Lücking, sp. nov.

35. Graphis flavominiata Moncada \& Lücking, sp. nov.

36. Graphis fournierii Lizano \& Lücking, sp. nov.

37. Graphis furcata Fée

= Graphis albissima Müll. Arg.

= Graphis foliicola Vain.

38. Graphis geraensis Redinger

39. G'aphis glaucescens Fée

= Graphis caesia Müll. Arg. (三Graphis angolensis

C. W. Dodge)

= Graphis glaucocaesia Müll. Arg.

= Graphis bulacana Vain.

= Graphis caesioglauca Redinger

40. Graphis gomezii Lücking, Will-Wolf \& Umaña, sp. nov.

41. Graphis gracilis (Fr.) Leight.

= Graphis analoga Nyl.

= Graphina renschiana Müll. Arg.

= Graphis antillarum var. manilensis Vain.

= Graphina symplocorum Zahlbr.

42. Graphis granulosa (Müll. Arg.) Lücking, comb. nov.

43. Graphis gregmuelleri Sipman \& Lücking, sp. nov.

44. Graphis haleana R. C. Harris

= Graphis cuiabensis Staiger [nom. inval.]

45. Graphis hyphosa Staiger

$=$ Graphis intricata f. meizospora Redinger

46. Graphis hypocrellina Lücking \& Chaves, sp. nov.

47. Graphis illinata Eschw.

48. Graphis inspersostictica Sipman \& Lücking, sp. nov.

49. Graphis insulana (Müll. Arg.) Lücking \& Sipman, comb. nov.

= Graphina subtartarea Müll. Arg.

= Graphis rudescens Nyl.

= Graphina robusta Müll. Arg.

= Graphis orientalis Vain.

= Graphis macgregorii Vain.

= Graphina sierraleonensis C. W. Dodge

50. Graphis inturgescens Kremp.

= Graphina acharii var. subintegra Zahlbr.

51. Graphis leprographa Nyl.

52. Graphis leptocarpa Fée

53. Graphis leptoclada Müll. Arg. = Graphis rigidula Müll. Arg.

54. Graphis librata C. Knight

$=$ Graphis diaphoroides Müll. Arg.

= Graphis celtidis Müll. Arg.

= Graphis filiformis Adaw. \& Makhija

55. Graphis lineola Ach.

$=$ Graphis handelii Zahlbr.

56. Graphis litoralis Lücking, Sipman \& Chaves, sp. nov.

57. Graphis longula Kremp. 
58. Graphis lucifica R. C. Harris

= Graphis rimulosa var. tetraspora Redinger

59. Graphis lumbricina Vain.

60. Graphis macella Kremp.

= Graphis subvestita Vain.

= Graphina carbocarpa Redinger

61. Graphis marginata Raddi

= Graphis leucoparypha Kremp.

= Graphis turgidula var. norstictica A. W. Archer

62. Graphis mexicana (Hale) Lücking, Lumbsch \&

Kalb

$=$ Graphis muscicola (Kalb) Staiger

= Topeliopsis globosa Aptroot

63. Graphis miniata Redinger

64. Graphis mirabilis Lücking, Sipman, Umaña \& Chaves, sp. nov.

65. Graphis multisulcata (Müll. Arg.) Lücking \& Chaves, comb. nov.

= Graphis analoga var. subradiata Nyl.

66. Graphis myrtacea (Müll. Arg.) Lücking, comb. nov. = Graphis crystallifera (Redinger) Staiger

67. Graphis nuda (H. Magn.) Staiger \& Lücking, comb. nov.

68. Graphis nudaeformis Lücking, sp. nov.

69. Graphis oryzaecarpa Lücking, sp. nov.

70. Graphis ovata (Fée) A. Massal. = Graphis nuda Staiger [nom. inval.]

71. Graphis oxyclada Müll. Arg.

72. Graphis paradisserpens Sipman \& Lücking, sp. nov.

73. Graphis paraserpens Lizano \& Lücking, sp. nov.

74. Graphis parilis Kremp.

= Graphis annulata Kremp.

= Graphina acromelaena Müll. Arg.

= Graphis acrophaea Müll. Arg.

75. Graphis pavoniana Fée

76. Graphis perstriatula Nyl.

= Graphis acuminata Vain.

= Graphis gracilescens Vain.

= Graphis polyschizans Vain.

= Graphina sulcata Fink

77. Graphis phaeospora Vain.

= Graphis subcinerea Staiger [nom. inval.]

78. Graphis pittieri Lücking, Umaña, Sipman \&

Chaves, sp. nov.

79. Graphis plagiocarpa Fée

= Graphina lumbschii var. deficiens A. W. Archer

80. Graphis platycarpa Eschw.

= Graphis sophistica Nyl.

81. Graphis plurispora (Redinger) Lücking \& Chaves, comb. nov.

82. Graphis proserpens Vain.

$=$ Graphis disserpens Vain. [nom. illeg., non $G$. disserpens Nyl.]

= Graphis sikkimensis Nagarkar \& Patw.

83. Graphis pseudocinerea Lücking \& Umaña, sp. nov.

84. Graphis pseudoserpens Chaves \& Lücking, sp. nov.

85. Graphis puiggarii (Müll. Arg.) Lücking, comb. nov. = Graphina endoschiza Müll. Arg.

86. Graphis rhizocola (Fée) Lücking \& Chaves, comb. nov.
$=$ Graphis cooperta Zenker

$=$ Graphis anguilliformis Taylor

= Graphis serpens Fée

= Graphis anguillaeformis var. infecunda Vain.

= Graphis illota var. leopoldensis Redinger

87. Graphis rimulosa (Mont.) Trevis.

= Graphis rimulosa var. brachycarpa Müll. Arg.

88. Graphis rockii Redinger

89. Graphis ruiziana (Fée) A. Massal

90. Graphis rustica Kremp.

= Graphis turgidula Müll. Arg.

= Graphis marginifera Vain.

$=$ Graplis tongloensis Vain

$=$ Graphis kjellbergii Redinger

91. Graphis sauroidea Leight.

92. Graphis schiffneri Zahlbr.

93. Graphis scripta (L.) Ach.

94. Graphis seminuda Müll. Arg.

= Graphis seminuda var. sublaevis Müll. Arg.

= Graphis catherinae A. W. Archer

95. Graphis sitiana Vain.

96. Graphis stenotera Vain. = Graphis flabellans Zahlbr.

97. Graphis striatula (Ach.) Spreng.

$=$ Graphis striatula var. substellaris Redinger

98. Graphis subchrysocarpa Lücking, nom. nov. $\equiv$ Phaeographis ochracea C. W. Dodge

99. Graphis subcontorta (Müll. Arg.) Lücking \& Chaves, comb. nov. = Graphis pseudoserpentina [nom. inval.]

100. Graphis subflexibilis Lücking \& Chaves, sp. nov.

101. Graphis sabhiascens (Müll. Ärg.) Lücking, comb. nov.

102. Graphis submarginata Lücking, nom. nor. $\equiv$ Graphis marginata G. Mey. \& Flot.

103. Graphis subruiziana Sipman, Chaves \& Lücking, sp. nov.

104. Graphis subturgidula Lücking \& Sipman, sp. nov.

105. Graphis subvirginea Nyl.

106. Graphis supertecta Müll. Arg.

107. Graphis symplecta Nyl.

108. Graphis tenella Ach.

= Phaeographis sulcata Müll. Arg.

= Graphis subglauconigra Nagarkar \& Patw.

109. Graphis tenellula Vain.

= Graphis tenella var. jatrophae Vain.

= Graphis spodoplaca Zahlbr.

$=$ Graphis inspersa Redinger

= Graphis tenellula var. eutypodes Vain.

110. Graphis tenoriensis Chaves \& Lücking, sp. nov.

111. Graphis tumidula (Fée) Spreng.

112. Graphis vestitoides (Fink) Staiger

$=$ Phaeographis cerviculata Redinger

113. Graphis virescens Müll. Arg.

= Graphis conferta Zenk.

114. Graphis vittata Müll. Arg.

$=$ Graphis treubii Zahlbr.

= Graphis theae Zahlbr.

115. Graphis xylophaga (R. C. Harris) Lücking, comb. nov. 
cioid), the G. dussii aggregate (lirellae short, sessile, with thick lateral thalline margin), and the G. triphora aggregate (lirellae sessile, with pruinose cover, Carbacanthographis-like).

Graphis nuda Group-This is the most distinctive group in the genus, strongly supported in the cladistic analysis (Lücking, 2008b) and easily distinguished by the short, prominent to sessile, jet-black labia resembling those of Melaspilea (Fig. 3G). The excipulum is completely carbonized, and striation is absent. Ascospores range from transversely septate to muriform and from small to large. Hymenial inspersion and secondary substances are mostly absent. The group is connected to the $G$. oxyclada group via species such as G. geraensis but also to the G. rhizocola group via $G$. mudaeformis and G. plagiocarpa, among other taxa. Molecular analysis (Staiger et al., 2006) suggests a closer relationship with the $G$. acharii group.

Graphis acharii Group-Species in this group are similar to those of the Graphis rhizocola group but eventually produce strongly striate labia (Fig. 3F). Ascospores are more commonly muriform, but large transversely septate ascospores are also found. Except for labia striation and the supposedly thicker paraphyses (see above), there are no distinct morphological differences between the two groups, although in the phenotype-based cladistic analysis they clearly separate (Lücking 2008b), and also Staiger (2002) regards them as different entities although closely related. Morphological data are inconclusive, as no member of the G. rhizocola group has been analyzed so far (Staiger et al., 2006). Ecologically, species of the G. rhizocola group are more confined to lowland rain forests, whereas those of the G. acharii group are more typical of montane rain forests.

Graphis cinerea Aggregate-This aggregate belongs in the Graphis acharii group and differs by the presence of type B hymenial inspersion. It is unclear whether the species of this aggregate form a natural taxon or are inspersomorphs of noninspersed species, but cladistic analysis suggests the former.

Graphis duplicata Group-The largest group within Graphis, characterized by delicate labia with distinct striation, usually the absence of a thalline cover, lack of inspersion and secondary substances in many species, and transversely septate to muriform, small to medium-sized ascospores. This group agrees in several aspects with the G. scripta group but differs consistently in the striate labia and the usually poorly developed or absent thalline margin. The carbonization of the excipulum varies in a similar way, being laterally or completely carbonized in closely related species.

Graphis proserpens Aggregate-This aggregate is nested within the preceeding group with which it agrees in all characters except that the excipulum is apically carbonized only.

Graphis caribica Aggregate-The two species belonging to this group agree with the Graphis duplicata group in all aspects except that the thallus is yellow-green, a color untypical for Graphis but commonly found in Phaeographis and allies.

The recognition of the groups delimited above is chiefly based on correlation of phenotypical characters analyzed by cladistic methods (Lücking, 2008b) but is also corroborated by ecological preferences (see also the section Multivariate Analysis of Habitat and Microhabitat Preferences). Except for the widespread Graphis duplicata group, the other groups have distinct habitat preferences: the $G$. nuda group and $G$. cinerea aggregate are restricted chiefly to montane zones, while the G. scripta and G. insulana groups are more commonly found at low to middle elevations. The G. farinulenta and G. caribica aggregate are typical of dry areas, where other groups of Graphis are rare or absent.

\section{The Genus Graphis in Costa Rica}

The present paper is a further TICOLICHEN contribution toward a lichen inventory of Costa Rica. It presents an assessment of the genus Graphis, based on study of literature data, more than 600 type specimens, and about 2000 new collections made during the three Ticolichen forays in 2002, 2003, and 2004 and further collection trips by the participants in 2005, 2006, and 2007. Keys are presented to all species, and all verified and new reports are listed as a table checklist (Table 3). Descriptions and illustrations are presented for newly described species and short diagnoses for all other taxa. No previous treatments of Graphis exist for Costa Rica; Müller Argoviensis (1891, 1893a) reported several species, but his accounts are largely unreliable, as shown by our studies of material in Müller Argoviensis's herbarium in Geneva (G). A large collection of Graphidaceae from Costa Rica, gathered by Dodge and his col- 
TABLE 4. List of names of Graphis and Graphina reported by Müller Argoviensis (1891, 1893a) and Breuss (2000, 2001, 2004), identified by Dodge et al. (FH) or listed in our previous Internet checklist (Umaña et al., 2002; http://www.fieldmuseum.org/ticolichen/checklist.html), which do not belong to Graphis or are to be excluded from Costa Rica because of misidentifications. For further data on previous misidentifications, see individual species entries. Authors of current names and identifications are given only for taxa and genera not treated in the present paper; names in boldface are species of Graphis accepted for Costa Rica and treated in this work.

Graphina acharii var. subducens (Nyl.) Zahlbr. (FH); material is Glyphis substriatula (Nyl.) Staiger.

Graphina acharii var. vestita Müll. Arg. (Müller Argoviensis, 1893a); material not checked.

Graphina acromelaena Müll. Arg. (Müller Argoviensis, 1893a); synonym of Graphis parilis.

Graphina agminalis (Nyl.) Zahlbr. (FH); material is Diorygma confluens (Fée) Kalb, Staiger \& Elix.

Graphina analoga var. monophora (Nyl.) Zahlbr. (FH); material is Graphis myrtacea.

Graphina anguina (Mont.) Müll. Arg. (Internet checklist); synonym of Thalloloma anguinum (Mont.) Trevis.

Graphina atrolabiata Redinger (FH); material is Platygramme caesiopruinosa (Fée) Fée.

Graphina bakeri Zahlbr. (FH); material is a mixture of Graphis rhizocola, G. acharii, and G. disserpens

Graphina balbisii (Fée) Müll. Arg. (Müller Argoviensis, 1891, 1893a); synonym of Hentithecium balbisii (Fée) Trevis

Graphina balbisii var. monospora Redinger (FH); material is Diorygma poitaei (Fée) Kalb, Staiger \& Elix.

Graphina chlorocarpa (Fée) Müll. Arg. (Breuss, 2004; FH); synonym of Hemithecium chlorocarpum (Fée) Trevis.;

material in FH is Diorygma confluens (Fée) Kalb, Staiger \& Elix p.p.

Graphina cleistostomna (Nyl.) Müll. Arg. (FH); material is Graphis sp. (no ascospores).

Graphina collatinensis Redinger (Umaña et al., 2002); synonym of Diorygma confluens (Fée) Kalb, Staiger \& Elix

Graphina confluens (Fée) Müll. Arg. (Breuss, 2001; FH); synonym of Diorygma confluens (Fée) Kalb, Staiger \& Elix.

Graphina dichotoma Müll. Arg. (FH); material is Graphis pseudoserpens.

Graphina dividens (Nyl.) Müll. Arg. (FH); material is Hemithecium rufopallidum (Vain.) Staiger.

Graphina epiglauca Müll. Arg. (Müller Argoviensis, 1893a); synonym of Diorygma epiglaucum (Müll. Arg.) Kalb,

Staiger \& Elix.

Graphina ertescens Redinger (FH); material is Graphis dichotoma.

Graplina glaucoleucoides (Nyl.) Zahlbr. (FH); material is Diorygma sp.

Graphina gracilis (Fée) Müll. Arg. (FH); material is Graphis sp.

Graphina haemographa Nyl. (Breuss, 2000); synonym of Thalloloma haemographum (Nyl.) Staiger.

Graphina heteroplaca Müll. Arg. (FH); material is Graphis illinata.

Graphina hologlanca Nyl. (FH); material is Hemithecium sp.

Graphina homograplia (Nyl.) Zahlbr. (FH); material is Acanthothecis subclavulifera Staiger \& Kalb.

Graphina ignea Kremp. (FH); material is Graphis chrysocarpa.

Graphina innata Redinger (FH); material is Graphis caesiella.

Graphina interstes Müll. Arg. (Müller Argoviensis, 1893; FH); synonym of Diorygma jungluhlmii (Mont. \& Bosch)

Kalb, Staiger \& Elix; material in FH is a mixture of Helminthocarpon leprevostii Fée and Platygramme

caesiopruinosa (Fée) Fée.

Graplina marcescens (Fée) Müll. Arg. (Umaña et al., 2002); synonym of Carbacanthographis marcescens (Fée) Staiger \& Kalb.

Graphina mendax (Nyl.) Müll. Arg. (Umaña et al., 2002); synonym of Diorygma junghulınii (Mont. \& Bosch) Kalb, Staiger \& Elix.

Graphina obtectula Müll. Arg. (Müller Argoviensis, 1893; FH); synonym of Diorygnta poitaei (Fée) Kalb, Staiger \& Elix; material in FH is Hemithecium sp.

Graplinna poitaei (Fée) Müll. Arg. (Müller Argoviensis, 1891; FH); synonym of Diorygna poitaei (Fée) Kalb, Staiger \& Elix; material in FH is Diorygma sp.

Graphina pseudanaloga (Vain.) Zahlbr. (FH); material is Graphis acharii.

Graplina reniformis (Fée) Müll. Arg. (Müller Argoviensis, 1893a); synonym of Diorygma reniforme (Fée) Kalb,

Staiger \& Elix.

Graphina robusta Müll. Arg. (Müller Argoviensis, 1891, 1893a); synonym of Graphis insulana.

Graphina rufopallens (Vain.) Zahlbr. (FH); material is Hemitlecium spec. nov.

Graphina rugulosa (Fée) Müll. Arg. (Breuss, 2004; FH); synonym of Graphis tumidula; material in FH is Graphis insulana; material cited by Breuss (2004) not checked.

Graphina sopliisticella Müll. Arg. (Müller Argoviensis, 1991; FH); holotype lacks carbonized excipulum and is not a Graphis; the other material is Graphis sp.

Graphina sulcatula Müll. Arg. (FH); material is Graplits sp.

Graphina vermicula (Fée) Müll. Arg. (Müller Argoviensis, 1891, 1893a); material not checked.

Graphina virginea (Eschw.) Müll. Arg. (Weber, 1993); synonym of Diorygma poitaei (Fée) Kalb, Staiger \& Elix.

Graplinia sp. nov. (FH); material is Graphis chrysocarpa.

Graphis afzelii Ach. (Müller Argoviensis, 1893; FH); synonym of Dyplolabia afzelii.

Graphis albida Fink (FH); material is Graphis rimulosa p.p. and Thecaria quassiicola Fée p.p.

Graplis albinula Müll. Arg. (FH); material is Hentitheciun chrysenteron (Mont.) Staiger, Kalb \& Lücking.

Graphis albinula var. clausa Vain. (FH); material is Platythecinum sp.

Graphis alborosella Nyl. (FH); material is Diorygma sp.

Graphis assimilis Nyl. (Müller Argoviensis, 1891, 1893; FH); material is Graphis dracenae. 
Graphis candidata Nyl. (FH); material is Graphis rhizocola.

Graphis colliculosa (Mont.) Nyl. (FH); material is Graphis sp.

Graphis conferta Zenker (FH); material is a mixture of Graphis rhizocola and G. puiggarii.

Graphis crebra Vain. (FH); material is Diorygma hieroglyphicum (Pers.) Staiger \& Kalb.

Graphis duplicata Ach. (FH); material is a mixture of Graphis duplicata and G. puiggarii.

Graphis duplicata var. nana (Fée) Müll. Arg. (Müller Argoviensis, 1891; FH); material reported by Müller

Argoviensis (1891) not checked; material in FH is a mixture of Graphis geraensis and G. tenella.

Graphis duplicata var. sublaevis Müll. Arg. (Müller Argoviensis, 1891, 1893a); material not checked.

Graphis durandi Müll. Arg. (Müller Argoviensis, 1891; FH); according to the description a species of Fissurina;

material in FH is a mixture of Hemithecium chlorocarpum (Fée) Trevis. and H. chrysenteron (Mont.) Staiger,

Kalb \& Lücking.

Graphis glaucella Müll. Arg. (FH); material is Diorygma confluens (Fée) Kalb, Staiger \& Elix.

Graphis glaucocaesia Müll. Arg. (Müller Argoviensis, 1893a); synonym of Graphis glaucescens.

Graphis grammitica Nyl. (FH); material is Diorygma hieroglyphicum p.p. and Graphis dichotoma p.p.

Graphis illinata Eschw. (FH); material is Graphis rhizocola.

Graphis immersa Fink (FH); material is Phaeographis sp.

Graphis intricata Fée (FH); material is Graphis tenella p.p., Melaspilea sp. p.p., and Opegrapha sp. p.p.

Graphis leuconephala Nyl. (Müller Argoviensis, 1893a); material is Fissurina sp.

Graphis platycarpella Müll. Arg. (Müller Argoviensis, 1891; FH); according to the description a species of Fissurina; material in FH is Graphis acharii.

Graphis rimulosa var. pulverulenta (Nyl.) Müll. Arg. (Müller Argoviensis, 1891, 1893a); material not checked.

Graphis rimulosa var. subduplicata Vain. (FH); material is Graphis sp.

Graphis rufula Mont, (FH); material is Graphis rhizocola.

Graphis scripta var. commatiformis Müll. Arg. (Müller Argoviensis, 1891); material not checked.

Graphis striatula var. sublaevis Müll. Arg. (Müller Argoviensis, 1893a); material not checked.

Graphis subcinerea Staiger [nom. inval., ICBN Art. 32, 35-37] (Staiger, 2002); synonym of Graphis phaeospora.

Graphis subrufula Müll. Arg. (Müller Argoviensis, 1893; FH); according to the description a species of

Hemithecium; material in $\mathrm{FH}$ is Graphis chrysocarpa.

Graphis tenella var. abbreviata Müll. Arg. (Müller Argoviensis, 1891; FH); material reported by Müller Argoviensis

(1891) not checked; material in FH is Graphis anfractnosa.

Graphis tenella var. flavicans Müll. Arg. (Müller Argoviensis, 1891); material not checked.

Graphis tenuescens Nyl. (FH); material is Graphis acharii.

Graphis triticea Nyl. (FH); material is Hemithecium chlorocarpum (Fée) Trevis.

Graphis tumidulella Fink (FH); material is Graphis argentata.

leagues and students, is housed at the Farlow Herbarium (FH). It is unknown whether Dodge, following his account on Costa Rican macrolichens (Dodge, 1933), planned to publish further treatments, including Graphidaceae. The FH material does not state who identified the collections, but from the sometimes widely disparate identifications of quite homogeneous material (Table 4), it is obvious that several persons were involved. The only recent and reliable contributions to Graphidaceae and Graphis in Costa Rica were made by Breuss $(2000,2001,2004)$. The present work is thus the first comprehensive and modern treatment of the genus in the country.

Species of Graphis are the predominant element among corticolous microlichen communities at low to medium elevations in Costa Rican ecosystems. About $7 \%$ of the collections made during the TICOLICHEN forays are representatives of Graphis, and 115 species could be identified, which makes Graphis the most diverse and abundant lichen genus in the country. It is generally believed that species of Graphis are most common in rain forests at low elevations. However, our data, based on collections from over 100 localities (Fig. 1), show that other members of Graphidaceae, such as Diorygma, Glyphis, Phaeographis, and Sarcographa, are more abundant in the lowland rain forest. Graphis itself has been found more abundantly and with greater number of species in the lowland dry forest and in montane rain forest at medium elevations (Fig. 6). A detailed ecological analysis based on more than 800 collections is given below, following the taxonomic treatment.

\section{Key to Costa Rican Species of Graphis}

The following keys use three different approaches to identify species of Graphis found in 


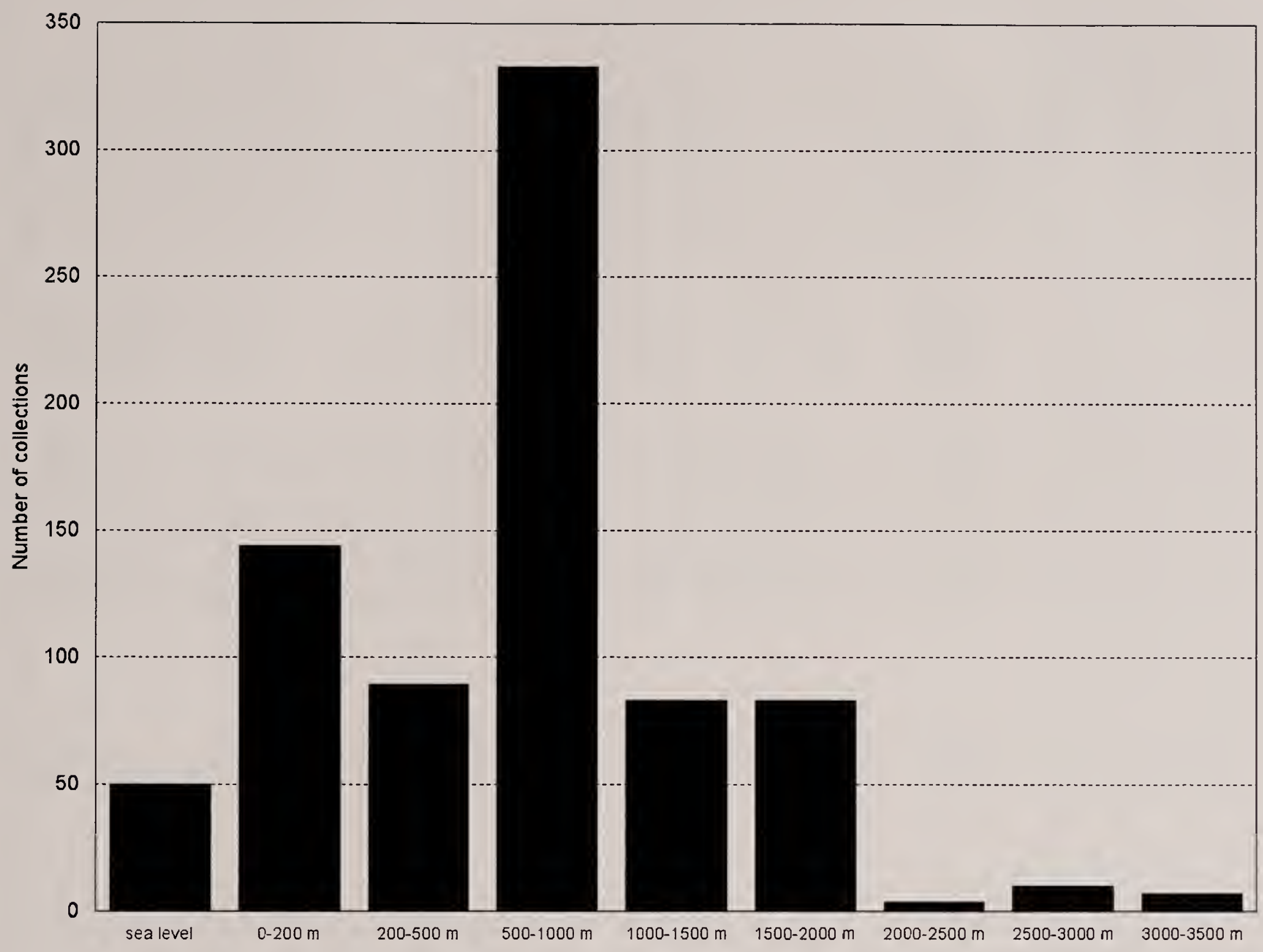

FIG. 6. Number of collections of Graphis per altitudinal zone in Costa Rica.

Costa Rica. The principal key is a traditional dichotomous key that uses main characters (labia striation and excipulum carbonization) to separate major key groups; these groups are artificial and used for practical purposes only and do not correspond to the presumedly natural groups and aggregates outlined above. Within each key group, ascospore type, hymenial inspersion, secondary chemistry, and lirellae morphology are used to identify species. A second key uses anatomical and chemical characters (ascospore type, excipulum structure, hymenial inspersion, secondary chemistry) leading to image plates with species sharing similar character states; the image plates are then used to identify species on the basis of lirellae morphol- ogy. A third approach is a table arrangement of species into six groups according to excipular structure and ascospore type (Table 5), where species are then identified using ascospore size, hymenial inspersion, lirellae morphology, and secondary chemistry as sorting characters. For difficult samples it is recommended to use all three keys and test whether the results coincide.

In rare cases, first-generation thalli of a species with usually striate labia might produce entire labia only. Therefore, if selecting entire labia as the key option does not lead to a satisfying identification, it is recommended to try also the key sections covering specimens with striate labia. 


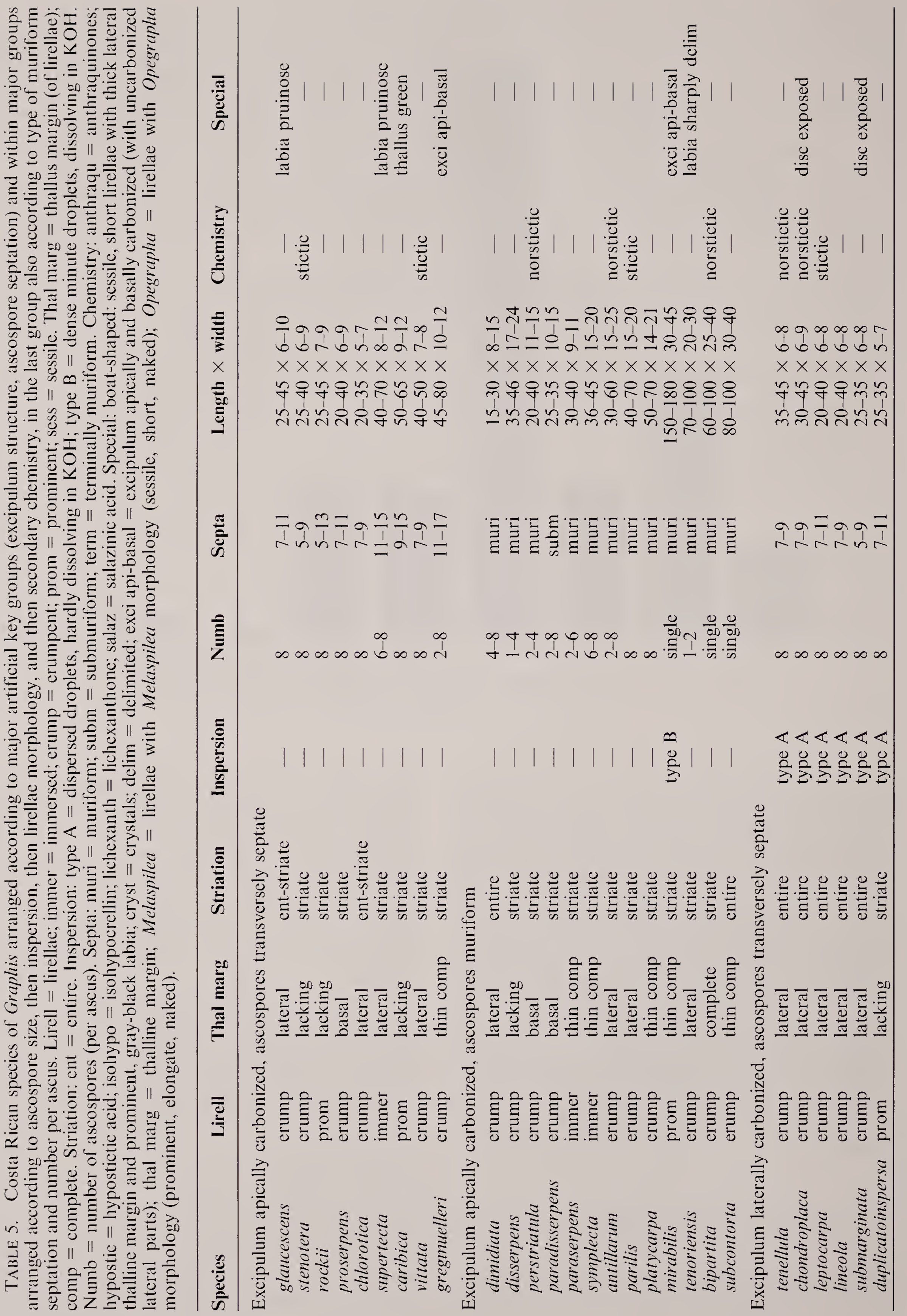




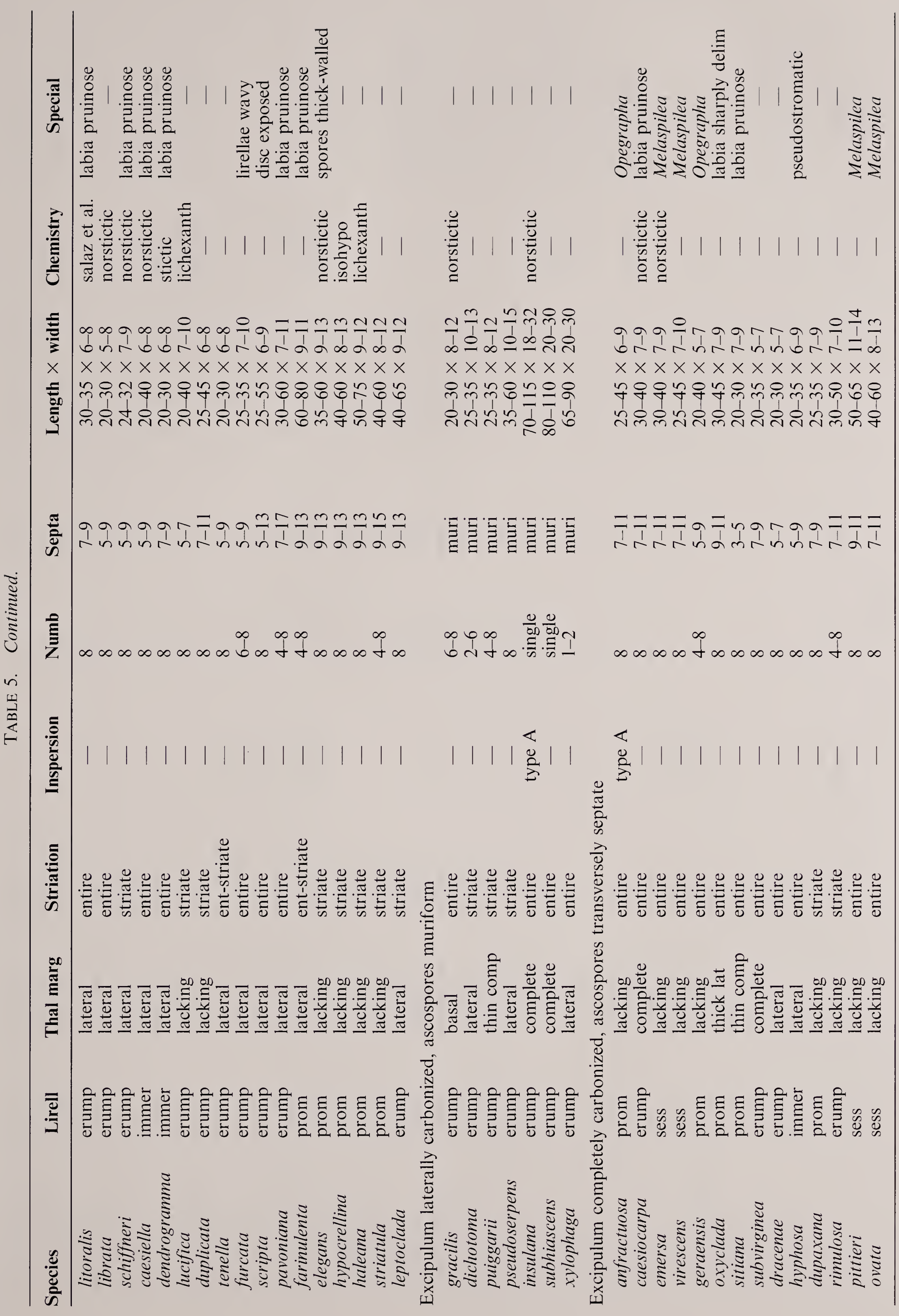




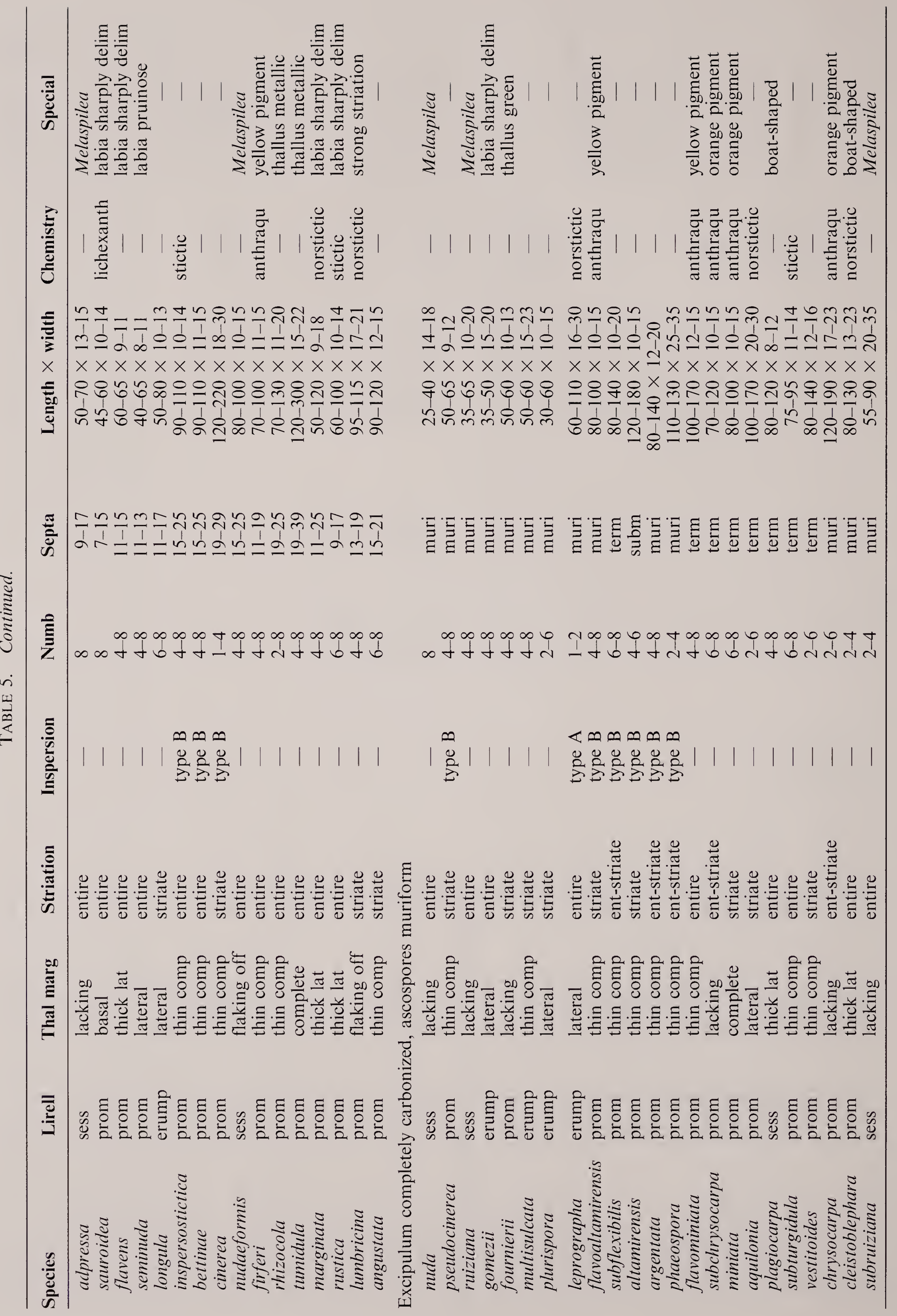




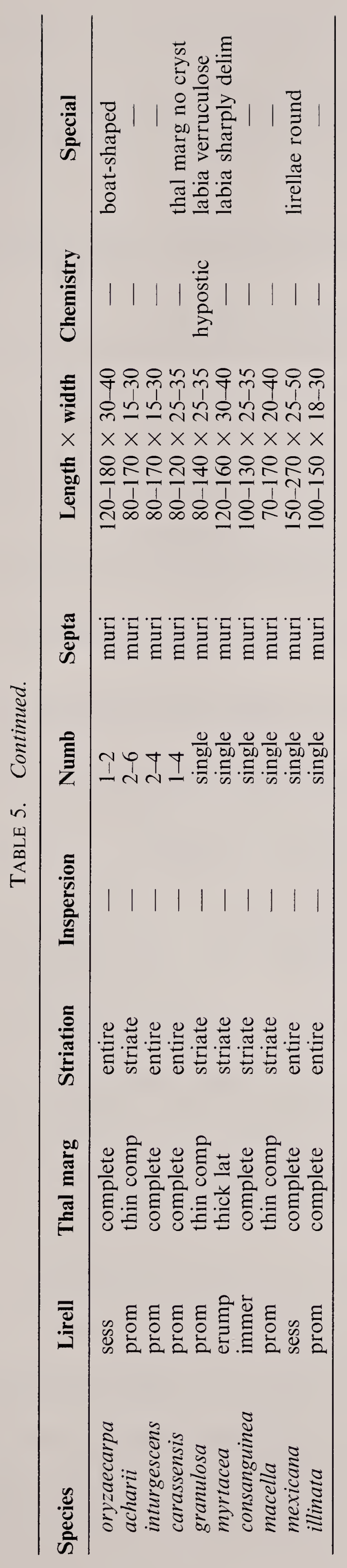




\section{Main Key}

1. Lirellae externally or internally with yellow, orange or dark red pigments (anthraquinones), reacting $\mathrm{K}+$ yellow to salmon, purple or green (best seen on sections under the microscope) . . Group I

1. Lirellae black or covered with white to gray thallus margin, or white to gray or brown pruinose,

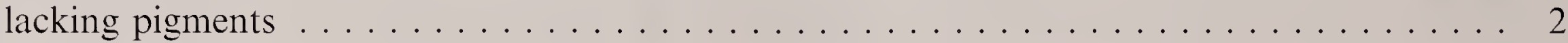

2. Labia entire ............................... 3

3. Excipulum apically to peripherally carbonized, internal lateral and basal parts hyaline or yellowish to orange brown, or rarely both apically and basally carbonized but laterally

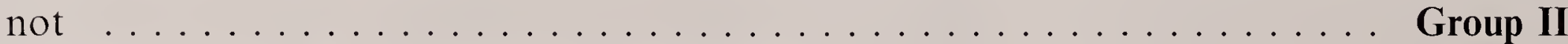

3. Excipulum laterally to completely carbonized . . . . . . . . . . . . . 4

4. Excipulum laterally carbonized down to substrate, basally below hymenium absent or uncarbonized ........................ Group III

4. Excipulum completely carbonized below hymenium . . . . . . . . . Group IV

2. Labia at least in part shallowly to deeply striate (in section crenulate), striae often filled with thallus remnants, crystals or degenerated remnants of old hymenia . . . . . . . . . 5

5. Excipulum apically to peripherally carbonized, internal lateral and basal parts hyaline or yellowish to orange brown . . . . . . . . . . . . . . . . . . Group $\mathbf{V}$

5. Excipulum laterally to completely carbonized $\ldots \ldots \ldots \ldots \ldots \ldots \ldots \ldots$

6. Excipulum laterally carbonized down to substrate, basally below hymenium absent or uncarbonized ......................... Group VI

6. Excipulum completely carbonized below hymenium . . . . . . . . G Group VII

\section{Group I: Lirellae with External or Internal, Yellow to Red Pigments}

1. Lirellae internally (and penetrating into substrate) with dark red pigment (isohypocrelline), $\mathrm{K}+$ green; excipulum laterally or rarely completely carbonized . . . . . . . G G. hypocrellina

1. Lirellae externally or between striae with yellow or orange pigments (anthraquinones), K+ yellow to salmon or purple; excipulum completely carbonized $\ldots \ldots \ldots \ldots \ldots \ldots \ldots \ldots$

2. Labia with orange, $\mathrm{K}+$ immediately pink-purple pigment $\ldots \ldots \ldots \ldots \ldots$

3. Ascospores regularly muriform, $120-200 \times 15-25 \mu \mathrm{m} \ldots \ldots \ldots \ldots$ G. chrysocarpa

3. Ascospores terminally muriform, $70-120 \times 10-15 \mu \mathrm{m} \ldots \ldots \ldots \ldots \ldots \ldots \ldots$

4. Lirellae with complete thalline cover, with pigment between striae only visible when thalline cover flakes off . . . . . . . . . . . . . . . . G. miniata

4. Lirellae lacking thalline cover, with pigment covering otherwise exposed labia

5. Labia striate; hymenium inspersed; ascospores regularly muriform . . G. flavoaltamirensis

5. Labia entire; hymenium clear; ascospores transversely septate or terminally muriform . . 6

6. Ascospores transversely multiseptate . . . . . . . . . . . . . G. firferi

6. Ascospores terminally muriform ............... G. flavominiata

\section{Group II: Labia Entire, Excipulum Apically to Peripherally Carbonized}

1. Ascospores transversely septate; thallus ecorticate; labia pruinose . . . . . . G. glaucescens

1. Ascospores muriform; thallus corticate; labia nonpruinose . . . . . . . . . . . . 2

2. Ascospores $15-30 \times 8-15 \mu \mathrm{m}, 4-8$ per ascus; lirellae with lateral thalline margin

G. dimidiata

2. Ascospores $60-110 \times 15-35 \mu \mathrm{m}$, single; lirellae with complete thalline margin

G. subcontorta 


\section{Group III: Labia Entire, Excipulum Laterally Carbonized}

1. Hymenium inspersed

2. Ascospores muriform, 50-115 $\times 15-30 \mu \mathrm{m}, 1(-2)$ per ascus.-Lirellae immersed-erumpent, with lateral to complete thalline cover; norstictic acid . . . . . . . . G. insulana

2. Ascospores transversely $5-11$-septate, $20-45 \times 6-10 \mu \mathrm{m}, 8$ per ascus . . . . . . . 3

3. Disc exposed ............................. 4

4. Disc nonpruinose, dark brown; norstictic acid . . . . . . . . G. chondroplaca

4. Disc white pruinose; no lichen substances ........... G. submarginata

3. Disc concealed ........................... 5

5. No lichen substances (if lirellae prominent lacking thalline margin, check $G$. anfractuosa with usually completely carbonized excipulum) . . . . . . G. lineola

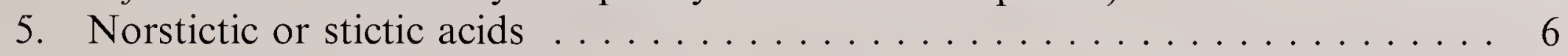

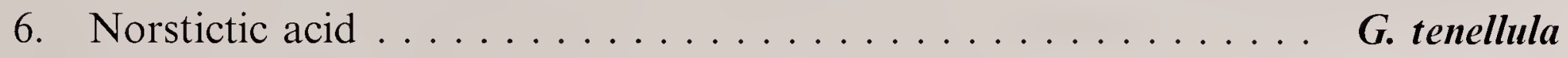

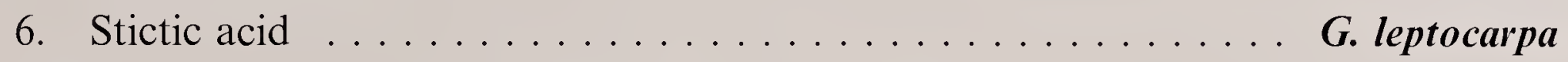

1. Hymenium clear . . . . . . . . . . . . . . . . . . . . . . 7

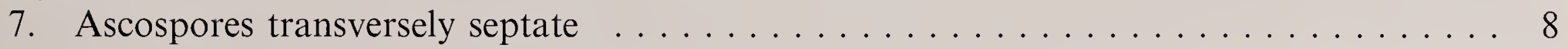

8. Ascospores (30-)40-80 × 8-11 $\mu \mathrm{m},(7-) 11-17$-septate.-Labia white pruinose along slit; thallus often partly or completely ecorticate and with bluish tinge . . . . . . . . 9

9. Lirellae prominent; thallus always ecorticate; ascospores $60-80 \mu \mathrm{m}$ long

G. farinulenta

9. Lirellae erumpent; thallus partly ecorticate; ascospores $40-60 \mu \mathrm{m}$ long

G. pavoniana

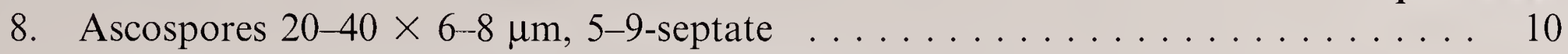

10. Disc exposed, white pruinose.-No lichen substances . . . . . . . G. scripta

10. Disc concealed ........................... 11

11. No lichen substances; lirellae usually wavy; thallus often partly ecorticate

G. furcata

11. Norstictic, stictic and/or salazinic acids . . . . . . . . . . . . 12

12. Stictic acid only.-Lirellae radiately branched; labia pruinose

12. Norstictic acid, with or without stictic and salazinic acid

G. dendrogramma

13. Norstictic, stictic and salazinic acids.-Lirellae immersed-erumpent; labia white pruinose $\ldots \ldots \ldots \ldots$. litoralis

13. Norstictic acid only ................... 14

14. Lirellae erumpent, partly branched; labia nonpruinose, black

G. librata

14. Lirellae immersed, radiately branched; labia white pruinose

G. caesiella

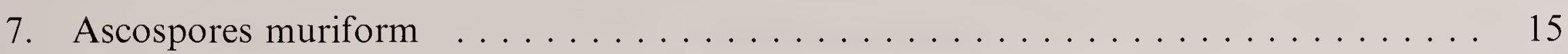

15. Ascospores $20-35 \times 8-13 \mu \mathrm{m}, 48$ per ascus; norstictic acid . . . . . . G. gracilis

15. Ascospores $60-90 \times 20-30 \mu \mathrm{m}, 1-2$ per ascus; no lichen substances . . . . . . 16

16. Lirellae with complete thalline margin (black labia hardly visible); ascospores single; thallus distinctly corticate .................G. subhiascens

16. Lirellae with lateral thalline margin (black labia distinct); ascospores 1-2 per ascus; thallus more or less ecorticate or with rough surface

G. xylophaga

\section{Group IV: Labia Entire, Excipulum Completely Carbonized}

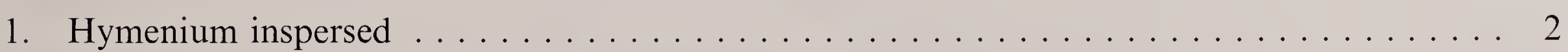

2. Ascospores transversely septate . . . . . . . . . . . . . . . 3

3. Ascospores $25-45 \times 6-9 \mu \mathrm{m}, 7-11$-septate; lirellae prominent with basal thalline margin,

Opegrapha-like

G. anfiactuosa 
3. Ascospores $90-110 \times 11-15 \mu \mathrm{m}, 15-25$-septate; lirellae prominent with lateral or thin

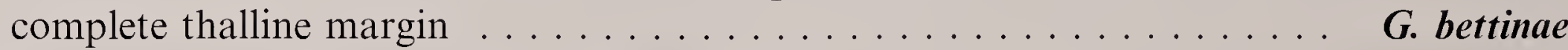

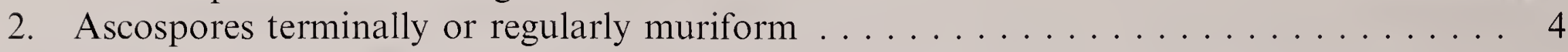

4. Ascospores terminally muriform.-Lirellae prominent with thin complete thalline margin;

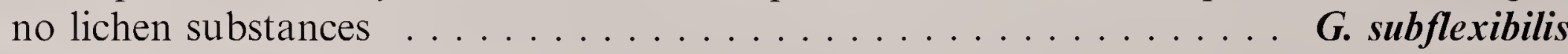

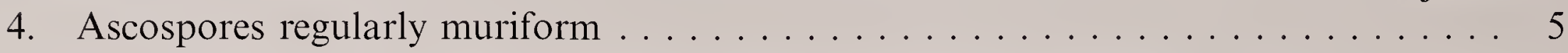

5. Norstictic acid; lirellae erumpent, short, with lateral thalline margin.-Ascospores

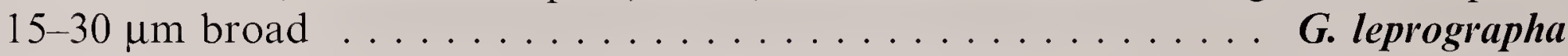

5. No lichen substances or stictic acid; lirellae prominent, distinctly elongate, with lateral

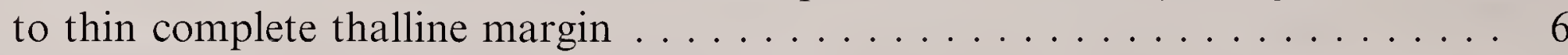

6. Stictic acid; ascospores $10-15 \mu \mathrm{m}$ broad .......... G. inspersostictica

6. No lichen substances; ascospores $12-20 \mu \mathrm{m}$ broad . . . . . . . G. argentata

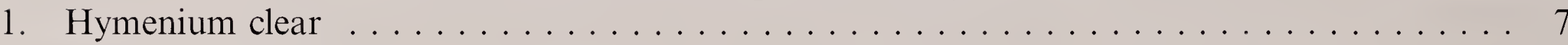

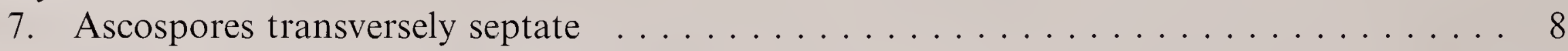

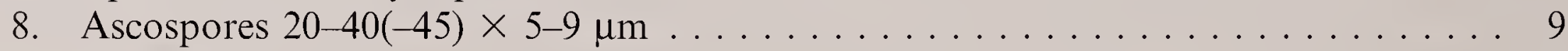

9. Norstictic acid ............................ 10

10. Lirellae sessile, lacking thalline margin, short, Melaspilea-like . . . G. emersa

10. Lirellae erumpent with lateral thalline margin; labia white pruinose

G. caesiocarpa

9. No lichen substances . . . . . . . . . . . . . . . . . . . . 11

11. Lirellae prominent to sessile, lacking thalline margin, short, Opegrapha- or Melaspilea-like ....................... 12

12. Lirellae sessile, Melaspilea-like; ascospores $25-45 \times 7-10 \mu \mathrm{m} \quad$ G. virescens

12. Lirellae prominent, Opegrapha-like; ascospores $20-40 \times 5-7 \mu \mathrm{m}$

G. geraensis

11. Lirellae erumpent to prominent, with lateral to complete thalline margin, distinctly elongate . . . . . . . . . . . . . . . 13

13. Lirellae with lateral thalline margin and jet-black, nonpruinose labia sharply delimited from thalline margin . . . . . . . . . . . . . . 14

14. Lirellae prominent, with thick lateral thalline margin, elongate and

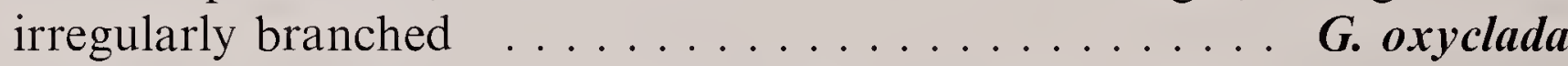

14. Lirellae erumpent, with lateral thalline margin, short and sparsely branched

G. dracenae

13. Lirellae with complete thalline margin or white pruinose labia . . . 15

15. Lirellae with thick complete thalline margin, labia invisible

G. subvirginea

15. Lirellae with lateral thalline margin, white-pruinose . . . . . . 16

16. Lirellae immersed, stellately branched and appearing pseudostromatic; ascospores 5-9-septate ............ G. hyphosa

16. Lirellae prominent, sparsely branched, not appearing pseudostromatic; ascospores $3-5$-septate . . . . . . . . . G. sitiana

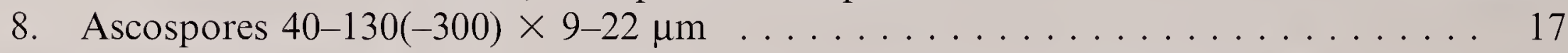

17. Lirellae sessile, short, lacking thalline margin and Melaspilea-like, rarely with complete thalline cover and then gray but cover often flaking off and exposing black labia.-No lichen substances . . . . . . . . . . . . . . . . . 18

18. Lirellae with thin complete thalline margin often flaking off; ascospores $70-130 \times$

$10-20 \mu \mathrm{m}$

G. nudaeformis

18. Lirellae lacking thalline margin, black, Melaspilea-like; ascospores $40-70 \times 7$ $15 \mu \mathrm{m}$

19. Ascospores grayish brown $\ldots \ldots \ldots \ldots \ldots \ldots \ldots$ G. pittieri

19. Ascospores colorless . . . . . . . . . . . . . . . . 20

20. Ascospores $40-50 \times 8-13 \mu \mathrm{m}$, with terminal gelatinous caps G. ovata

20. Ascospores 50-70 $\times 13-15 \mu \mathrm{m}$, lacking gelatinous caps ... G. adpressa 
17. Lirellae prominent, distinctly elongate, with lateral to complete, persistent thalline margin . . . . . . . . . . . . . . . . . . . . . . . . 21

21. Norstictic or stictic acids.-Ascospores $60-120 \times 10-18 \mu \mathrm{m} \ldots \ldots \ldots 22$

22. Stictic acid

G. rustica

22. Norstictic acid

23. Lirellae with thick lateral thalline margin

G. marginata

23. Lirellae with thin complete thalline cover that usually flakes off and exposes the jet-black excipular surface ........... G. lumbricina

21. No lichen substances .......................... 24

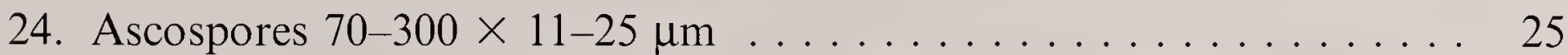

25. Ascospores $130-300 \times 15-25 \mu \mathrm{m}$; lirellae with thick complete thalline

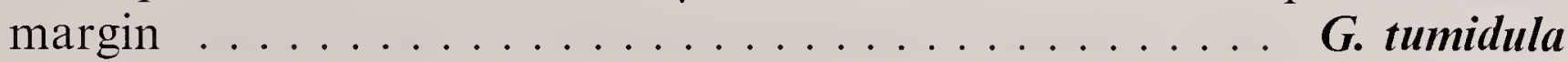

25. Ascospores $70-130 \times 11-17 \mu \mathrm{m}$; lirellae with thin complete thalline margin that leaves upper portion of labia exposed .... G. rhizocola

24. Ascospores $40-70 \times 9-11 \mu \mathrm{m} \ldots \ldots \ldots \ldots . \ldots \ldots . \ldots . \ldots . \ldots 26$

26. Lirellae lacking thalline margin (or developed basally); lichexanthone . . . . . . . . . . . . . . . . . . . . . . . G. sauroidea

26. Lirellae with lateral thalline margin; no lichen substances . . . . 27

27. Lirellae with thin lateral thalline margin; labia white pruinose along slit . . . . . . . . . . . . . . . . . . G. seminuda

27. Lirellae with thick lateral thalline margin; labia nonpruinose, jetblack and sharply delimited from thalline margin . . . G. flavens

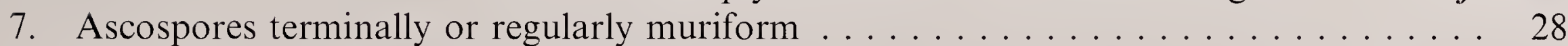

28. Ascospores terminally muriform . . . . . . . . . . . . . . . . . . . . . . 29

29. Hymenium inspersed; lirellae with thin complete thalline margin

G. subflexibilis

29. Hymenium clear; lirellae with thick lateral or complete thalline margin . . . . 30

30. Lirellae prominent, distinctly elongate, with complete thalline margin; stictic acid ....................... G. subturgidula

30. Lirellae sessile, short, robust, with thick lateral thalline margin; no lichen substances

G. plagiocarpa

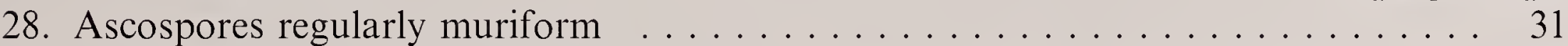

31. Lirellae rounded to shortly ellipsoid or Melaspilea-like, prominent to sessile . . 32

32. Norstictic acid; lirellae with thick lateral thalline margin . . G. cleistoblephara

32. No lichen substances; lirellae lacking or with complete thalline margin or thick

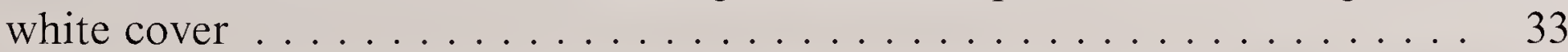

33. Lirellae with complete thalline margin or labia with white cover, rounded to very shortly ellipsoid; ascospores $120-270 \times 25-50 \mu \mathrm{m} \ldots \ldots \ldots 34$

34. Lirellae very shortly ellipsoid; labia with white cover different from lateral thalline margin; inner part of excipulum with clusters of

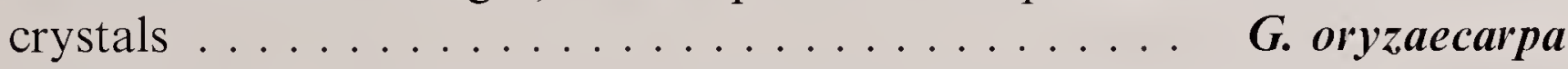

34. Lirellae mostly rounded; labia with complete thalline margin but often black along slit; clusters of crystals between excipulum and thalline margin ........................ G. mexicana

33. Lirellae lacking thalline cover, short, Melaspilea-like; ascospores $25-80 \times 10$

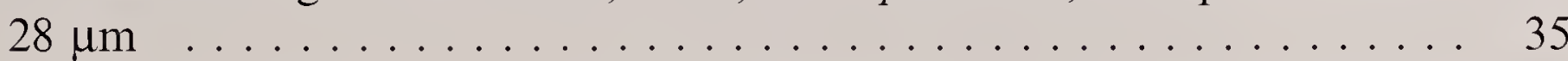

35. Ascospores 55-90 $\times 20-35 \mu \mathrm{m}, 2-4$ per ascus.-Labia nonpruinose

G. subruiziana

35. Ascospores $25-65 \times 6-20 \mu \mathrm{m}, 4-8$ per ascus . . . . . . . . 36

36. Ascospores $35-65 \times 10-20 \mu \mathrm{m}$; labia thinly white pruinose along

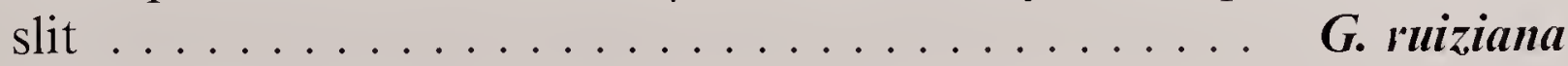

36. Ascospores $25-40 \times 6-10 \mu \mathrm{m}$; labia nonpruinose . . . G G. nuda

31. Lirellae distinctly elongate, erumpent to prominent . . . . . . . . . . . . 37

37. Thallus and lirellae verruculose; hypostictic acid ....... G. granulosa 
37. Thallus and lirellae smooth to slightly uneven; no lichen substances .... 38 38. Lirellae erumpent, with basal to lateral thalline cover and sharply delimited, jetblack labia; ascospores $35-50 \mu \mathrm{m}$ long, $4-8$ per ascus . . . . . . G. gomezii

38. Lirellae prominent, with complete thalline margin, white-gray (if apically dark gray, with thin thalline cover, compare G. acharii: first-generation lirellae); ascospores $80-170 \mu \mathrm{m}$ long, $1-4$ per ascus . . . . . . . . . . . . 39

39. Ascospores single .................. G. illinata

39. Ascospores $2-4$ per ascus . . . . . . . . . . . . . 40

40. Thalline margin with clusters of crystals .... G. inturgescens

40. Thalline margin lacking crystals ......... G. carassensis

\section{Group V: Labia Striate, Excipulum Apically to Peripherally Carbonized}

1. Ascospores transversely septate

2. Excipulum apically and basally carbonized; lirellae with complete thalline margin, whitegray

G. gregmuelleri

2. Excipulum apically (to peripherally) carbonized only; lirellae white pruinose or lacking complete thalline margin and then black in upper parts $\ldots \ldots \ldots \ldots \ldots \ldots \ldots \ldots$

3. Lirellae immersed; labia white pruinose . . . . . . . . . . . . . . 4

4. Thallus ecorticate; ascospores $25-35 \times 6-8 \mu \mathrm{m}, 7-9$-septate $\ldots$. G. glaucescens

4. Thallus corticate; ascospores 40-70 $\times 8-12 \mu \mathrm{m}, 11-15$-septate . . . G. supertecta

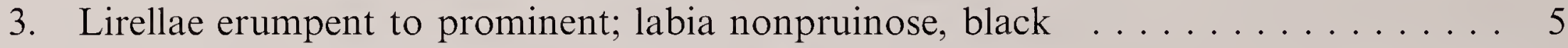

5. Thallus yellowish green; ascospores $50-65 \times 9-12 \mu \mathrm{m} \ldots \ldots \ldots$ G. caribica

5. Thallus white to pale yellowish gray; ascospores $20-50 \times 5-10 \mu \mathrm{m} \ldots \ldots \ldots 6$

6. Stictic acid .......................... 7

7. Lirellae immersed-erumpent, with lateral thalline margin; ascospores 40

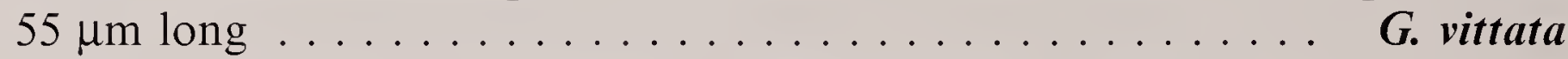

7. Lirellae erumpent to prominent, lacking thalline margin; ascospores 25-

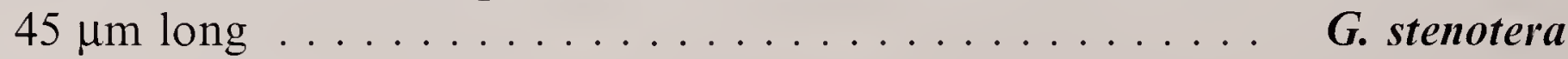

6. No lichen substances $\ldots \ldots \ldots \ldots \ldots \ldots \ldots \ldots \ldots \ldots$

8. Lirellae prominent, lacking thalline margin $\ldots \ldots \ldots \ldots \ldots$. rockii

8. Lirellae immersed to erumpent, with basal to lateral thalline margin . . 8

9. Lirellae immersed-erumpent, with lateral thalline margin G. chlorotica

9. Lirellae erumpent, with basal thalline margin ....... G. proserpens

1. Ascospores muriform . . . . . . . . . . . . . . . . . . . . . . 10

10. Excipulum apically and basally carbonized; ascospores $150-180 \mu \mathrm{m}$ long; hymenium

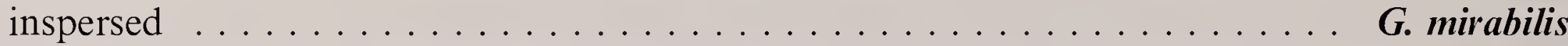

10. Excipulum basally uncarbonized (very rarely dark brown); ascospores 20-100 $\mu \mathrm{m}$ long;

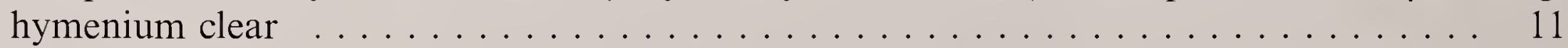

11. Ascospores $(60-) 70-100 \times(20-) 25-40 \mu \mathrm{m}, 1-2$ per ascus $\ldots \ldots \ldots \ldots \ldots \ldots$

12. Norstictic acid; lirellae immersed ................ G. bipartita

12. No lichen substances; lirellae erumpent with jet-black, sharply delimited labia with conspicuous, sharply delimited white lines between striae (filled with clusters of calcium oxalate crystals) $\ldots \ldots \ldots \ldots \ldots \ldots \ldots \ldots \ldots$ tenoriensis

11. Ascospores $20-60(-70) \times 10-20(-25) \mu \mathrm{m},(1-) 2-8$ per ascus $\ldots \ldots \ldots \ldots \ldots . \ldots 13$

13. Norstictic or stictic acids . . . . . . . . . . . . . . . . . . 14

14. Stictic acid; lirellae with thick lateral thalline margin.-Ascospores 40-60(-70) $\times$ $15-20 \mu \mathrm{m} \ldots \ldots \ldots \ldots \ldots \ldots \ldots \ldots \ldots \ldots \ldots \ldots \ldots \ldots$. parilis

14. Norstictic acid; lirellae with basal to lateral thalline margin . . . . . . . 15

15. Ascospores $30-60 \times 15-25 \mu \mathrm{m} \ldots \ldots \ldots \ldots \ldots$ G. antillarum

15. Ascospores $20-40 \times 10-15 \mu \mathrm{m} \ldots \ldots \ldots \ldots \ldots$ G. perstriatula

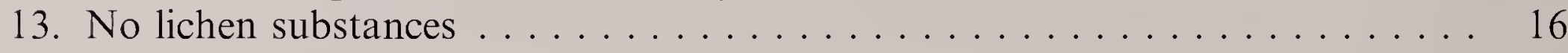


16. Ascospores $50-70 \mu \mathrm{m}$ long; lirellae with lateral to thin complete thalline margin ........................ G. platycarpa

16. Ascospores $25-45 \mu \mathrm{m}$ long; lirellae lacking or with lateral thalline margin 17

17. Ascospores $15-25 \mu \mathrm{m}$ broad . . . . . . . . . . . . . . 18

18. Lirellae erumpent, with lateral thalline margin; ascospores $1-4$ per

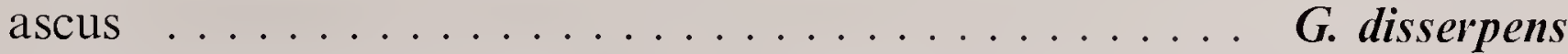

18. Lirellae immersed-erumpent, with complete thalline cover; ascospores 4 8 per ascus

G. symplecta

17. Ascospores $9-15 \mu \mathrm{m}$ broad ... . . . . . . . . . . . . . 19

19. Lirellae with lateral thalline margin; ascospores $9-11 \mu \mathrm{m}$ broad, more than 3 times as long as broad ............ G. paraserpens

19. Lirellae lacking thalline margin; ascospores $10-15 \mu \mathrm{m}$ broad, less than 3 times as long as broad ............... . paradisserpens

\section{Group VI: Labia Striate, Excipulum Laterally Carbonized}

1. Ascospores transversely septate; lichen substances absent or present $\ldots \ldots \ldots \ldots \ldots \ldots$

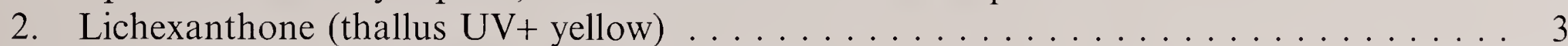

3. Ascospores $50-85 \mu \mathrm{m}$ long, 9-19-septate ................ G. haleana

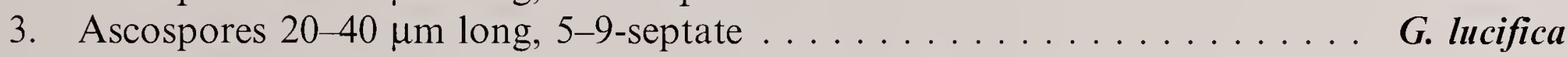

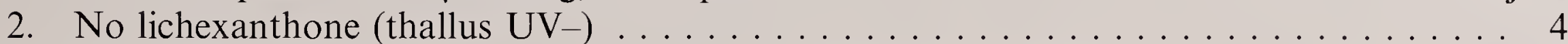

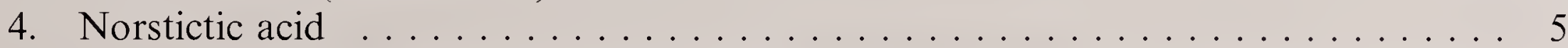

5. Lirellae erumpent-prominent, lacking thalline margin; labia nonpruinose; ascospores

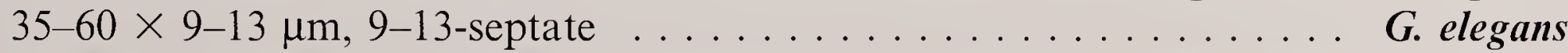

5. Lirellae immersed-erumpent, with lateral thalline margin; labia white pruinose;

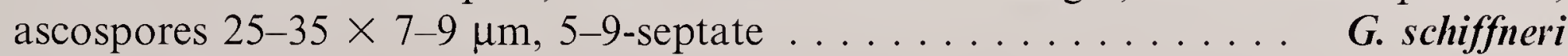

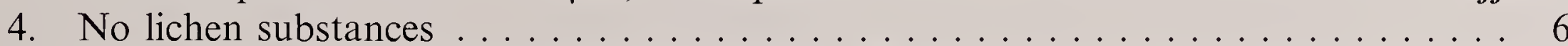

6. Lirellae with complete thalline margin or white pruinose; labia gray; ascospores 60 $80 \mu \mathrm{m}$ long . . . . . . . . . . . . . . . . . . farinulenta

6. Lirellae with basal to lateral thalline margin, nonpruinose; labia black; ascospores 20 $65 \mu \mathrm{m}$ long . . . . . . . . . . . . . . . . . . . . . . 7

7. Ascospores $40-65 \times 8-12 \mu \mathrm{m} \ldots \ldots \ldots \ldots \ldots \ldots \ldots \ldots$

8. Lirellae prominent, lacking thalline margin $\ldots \ldots \ldots \ldots$. . striatula

8. Lirellae erumpent, with lateral thalline margin ......... G. leptoclada

7. Ascospores $20-45 \times 6-9 \mu \mathrm{m} \ldots \ldots \ldots \ldots \ldots \ldots \ldots \ldots$

9. Hymenium inspersed ............... G. duplicatoinspersa

9. Hymenium clear . . . . . . . . . . . . . . . . . . . . 10

10. Lirellae erumpent to prominent, lacking thalline margin . . G. duplicata

10. Lirellae immersed to erumpent, with lateral thalline margin . . G. tenella

1. Ascospores muriform; no lichen substances . . . . . . . . . . . . . . . . . . 11

11. Ascospores 35-60 $\mu \mathrm{m}$ long; lirellae partly and irregularly branched ... G. . pseudoserpens

11. Ascospores $25-35 \mu \mathrm{m}$ long; lirellae either short and mostly unbranched or radiately branched

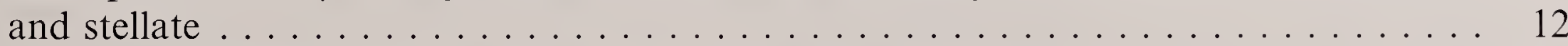

12. Lirellae short, mostly unbranched, with thin complete thalline cover .... G. puiggarii

12. Lirellae radiately branched to stellate, with basal to lateral thalline margin

G. dichotoma

\section{Group VII: Labia Striate, Excipulum Completely Carbonized}

1. Hymenium inspersed.-No lichen substances; lirellae prominent to sessile, with lateral to thin

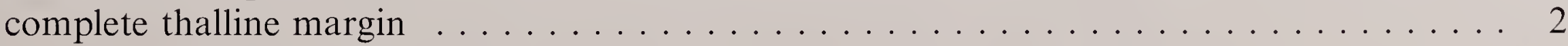

2. Ascospores transversely septate.-Ascospores $120-220 \times 15-30 \mu \mathrm{m} \ldots \ldots$. . G. cinerea

2. Ascospores terminally or regularly (sub)muriform $\ldots \ldots \ldots \ldots \ldots \ldots \ldots$ 
3. Ascospores terminally muriform; lirellae rather short and broad.-Ascospores $60-150 \times$ $12-20 \mu \mathrm{m} \ldots \ldots \ldots \ldots \ldots \ldots \ldots \ldots \ldots \ldots \ldots \ldots \ldots \ldots \ldots \ldots \ldots$ sublexibilis

3. Ascospores regularly (sub)muriform; lirellae distinctly elongate . . . . . . . . . 4

4. Ascospores $50-70 \times 9-12 \mu \mathrm{m} \ldots \ldots \ldots \ldots \ldots \ldots$ G. pseudocinerea

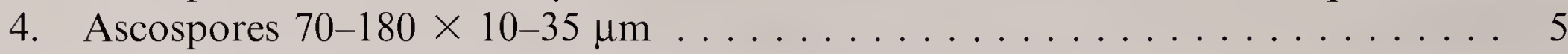

5. Ascospores $1-4$ per ascus, $25-35 \mu \mathrm{m}$ broad . . . . . . . . G. phaeospora

5. Ascospores $4-8$ per ascus, $10-25 \mu \mathrm{m}$ broad . . . . . . . . . . . . 6

6. Ascospores submuriform, $120-180 \times 10-15 \mu \mathrm{m}, 10-14$ times as long as

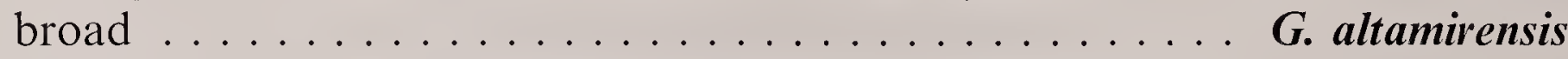

6. Ascospores muriform, $80-140 \times 12-20 \mu \mathrm{m}, 5-7$ times as long as broad .

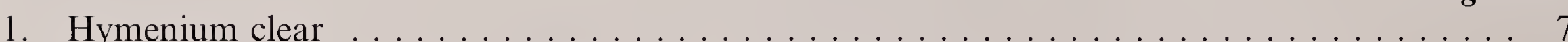

7. Ascospores transversely septate ...................... 8

8. Ascospores $80-120 \times 12-15 \mu \mathrm{m}$; lirellae prominent to sessile . . . . . . . . . . 9

9. Norstictic acid; thalline cover often flaking off and exposing jet-black labia; lirellae distinctly elongate . . . . . . . . . . . . . . . . . Iumbricina

9. No lichen substances; thalline cover persistent; lirellae rather short and broad

G. angustata

8. Ascospores $25-80 \times 7-13 \mu \mathrm{m}$; lirellae erumpent to prominent $\ldots \ldots \ldots \ldots \ldots$

10. Ascospores $50-80 \times 10-13 \mu \mathrm{m}$; lirellae with lateral thalline margin . . . G. longula

10. Ascospores small, $25-50 \times 7-10 \mu \mathrm{m}$; lirellae lacking or with basal thalline margin

11. Ascospores $30-50 \mu \mathrm{m}$ long, $4-8$ per ascus, $7-13$-septate; lirellae erumpent . .

11. Ascospores $25-35 \mu \mathrm{m}$ long, 8 per ascus, $5-9$-septate; lirellae prominent $G$. dupaxana

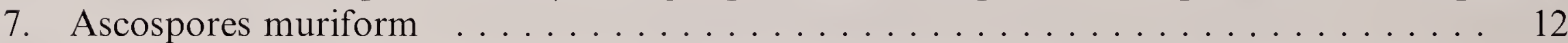

12. Ascospores terminally muriform.-Lirellae prominent, with complete thalline margin 13

13. Norstictic acid; ascospores $100-170 \times 14-20 \mu \mathrm{m} \ldots \ldots \ldots$. . . G. aquilonia

13. No lichen substances; ascospores $80-140 \times 12-16 \mu \mathrm{m} \ldots \ldots \ldots$. . . vestitoides

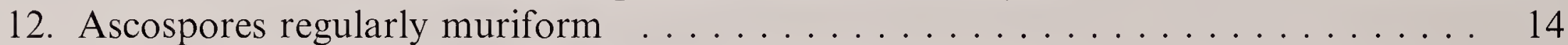

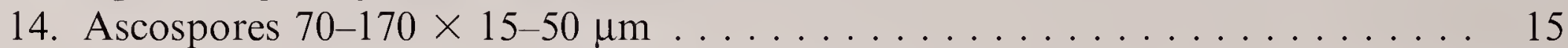

15. Thallus and lirellae verruculose; hypostictic acid ....... G. granulosa

15. Thallus and lirellae smooth to slightly uneven; no lichen substances . . . 16

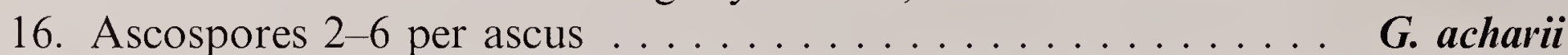

16. Ascospores single; lirellae immersed to prominent, with lateral to thin complete thalline margin ................... 17

17. Upper part of labia jet-black and nitidous, sharply delimited from white lateral thalline margin; striae filled with large clusters of calcium oxalate crystals . . . . . . . . . . . . . . . . . G. myrtacea

17. Labia covered by thalline layer, dark gray; striae lacking large clusters of crystals ......................... 18

18. Lirellae prominent, with thin thalline cover . . . . . G. macella

18. Lirellae immersed, with thick thalline cover ... G. Gonsanguinea

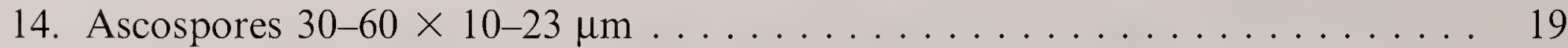

19. Lirellae erumpent, with lateral to thin complete thalline margin; thallus white to pale gray . . . . . . . . . . . . . . . . . . . . 20

20. Ascospores $10-15 \mu \mathrm{m}$ broad ............... G. plurispora

20. Ascospores $15-23 \mu \mathrm{m}$ broad .............. G. multisulcata

19. Lirellae prominent to sessile, lacking thalline margin; thallus yellowish green to olive brown ......................... 21

21. Labia with dark brown pruina along slit; paraphyses with thick, gelatinous walls, partly anastomosing . . . . . . . . . . . [Glyphis substriatula]

21. Labia nonpruinose; paraphyses with thin walls, unbranched ... G. fournierii 


\section{Key to Image Plates}

1. Yellow, orange or red, $\mathrm{K}+$ salmon to pink or green pigments present on or within lirellae . Fig. 7

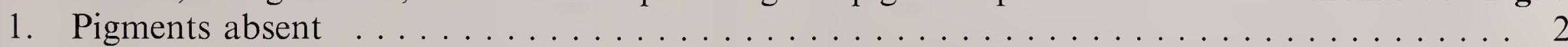

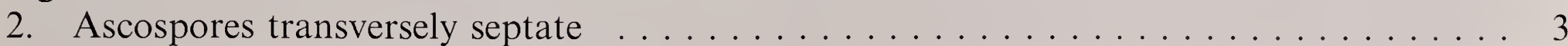

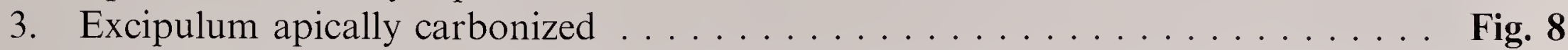

3. Excipulum laterally or completely carbonized (or apically and basally carbonized) . 4

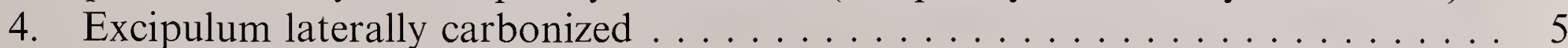

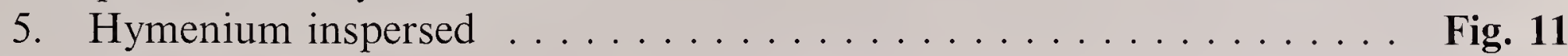

5. Hymenium clear . . . . . . . . . . . . . . . . . . . . . 6

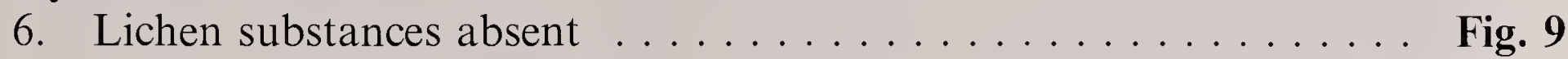

6. Lichen substances present . . . . . . . . . . . . . . . . Fig. 10

4. Excipulum completely carbonized (or apically and basally carbonized) $\ldots \ldots 7$

7. Ascospores small to medium sized $(20-70 \mu \mathrm{m}$ long) . . . . . . . . . . . . 8

8. Lichen substances absent; hymenium clear . . . . . . . . . . . . . . . 9

9. Ascospores small $(20-50 \mu \mathrm{m}$ long $) \ldots \ldots \ldots \ldots$ Fig. 12, 13A-B

9. Ascospores medium sized $(50-70 \mu \mathrm{m}$ long $) \ldots \ldots \ldots$. . . . Fig. 13C-H

8. Lichen substances present or hymenium inspersed . . . . . . . . . 10

10. Hymenium inspersed; lichen substances absent . . . . . . Fig. 14A-B

10. Hymenium clear; lichen substances present . . . . . . . Fig. 14C-H

7. Ascospores large to very large $(70-220 \mu \mathrm{m}$ long $) \ldots \ldots \ldots \ldots \ldots$

11. Lichen substances absent; hymenium clear . . . . . . . . . . Fig. 15

11. Lichen substances present or hymenium inspersed . . . . . . F Fig. 16

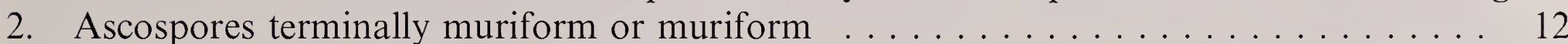

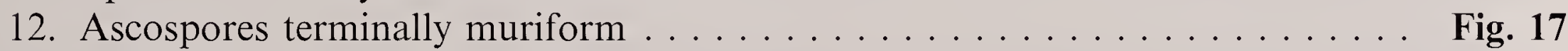

12. Ascospores regularly muriform $\ldots \ldots \ldots \ldots \ldots \ldots \ldots \ldots \ldots \ldots \ldots$

13. Excipulum apically carbonized (or apically and basally carbonized) . . . . . . 14

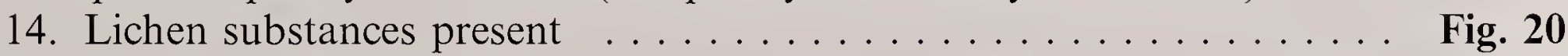

14. Lichen substances absent . . . . . . . . . . . . . . . . . . . 15

15. Ascospores small $(20-50 \mu \mathrm{m}$ long $) \ldots \ldots \ldots \ldots \ldots$ Fig. 18

15. Ascospores medium sized to large $(50-220 \mu \mathrm{m}$ long $) \ldots \ldots$. . . Fig. 19

13. Excipulum laterally to completely carbonized . . . . . . . . . . . . . 16

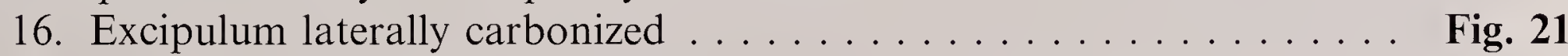

16. Excipulum completely carbonized . . . . . . . . . . . . . . . . . . 17

17. Lichen substances absent; hymenium clear . . . . . . . . . . . . . . 18

18. Ascospores small to medium sized $(20-70 \mu \mathrm{m}$ long $) \ldots$ Fig. $22 \mathrm{~A}-\mathrm{G}$

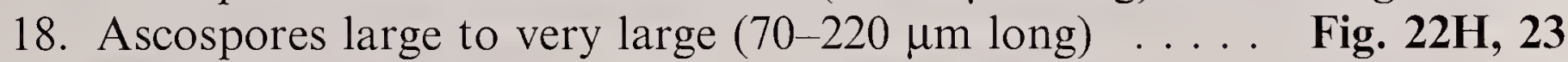

17. Lichen substances present or hymenium inspersed . . . . . . . . . . . 19

19. Hymenium inspersed; lichen substances absent . . . . . . . Fig. 24

19. Hymenium clear; lichen substances present . . . . . . . F Fig. 25

\section{Systematic Account}

\section{Notes on Format}

In the following account, species are listed in alphabetical order to facilitate searching for individual taxa. New species feature a detailed description and discussion, while other species are briefly diagnosed and discussed in terms of their taxonomy. Nomenclatural references, synonymy, and type collections are cited when deviating from the recent revision by Staiger (2002) or when the species was not included in that work.

With a few exceptions, all species are illustrated by habitus photographs that are arranged in the following way: all species that share the same ascospore type, chemistry, and excipulum type are grouped together on the same plate to facilitate their distinction on the basis of morphological features and to serve as an image guide to identify taxa with similar anatomical 

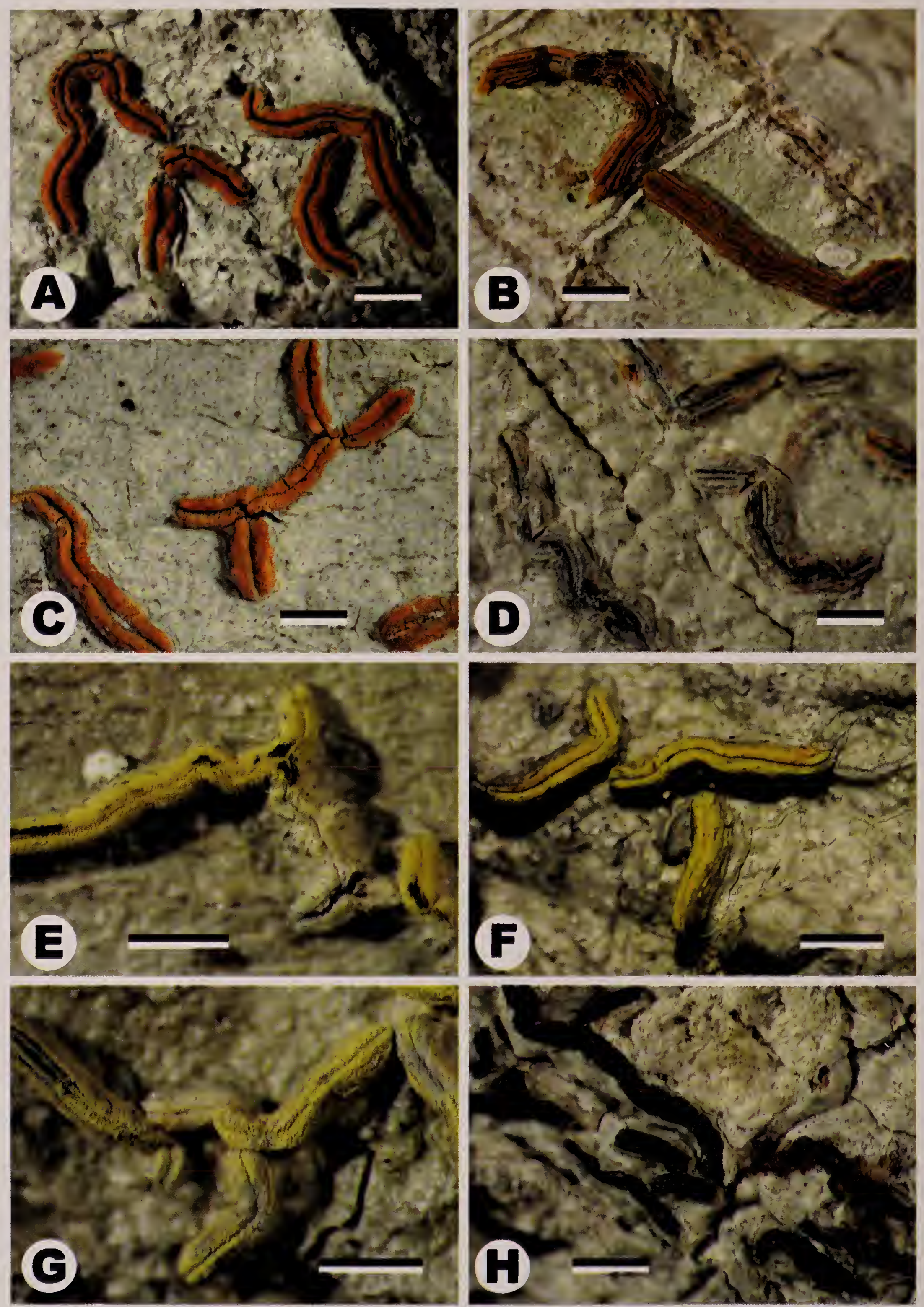

FIG. 7. Species with pigments. (A-B) Graphis chrysocarpa (muriform, morphs with entire and striate labia). (C) Graphis subchrysocarpa (terminally muriform; type). (D) Graphis miniata (terminally muriform). (E) Graphis firferi (transverse; type). (F) Graphis flavominiata (terminally muriform; type). (G) Graphis flavoaltamirensis (inspersed, muriform; type). (H) Graphis hypocrellina (type). Scale $=1 \mathrm{~mm}$. 

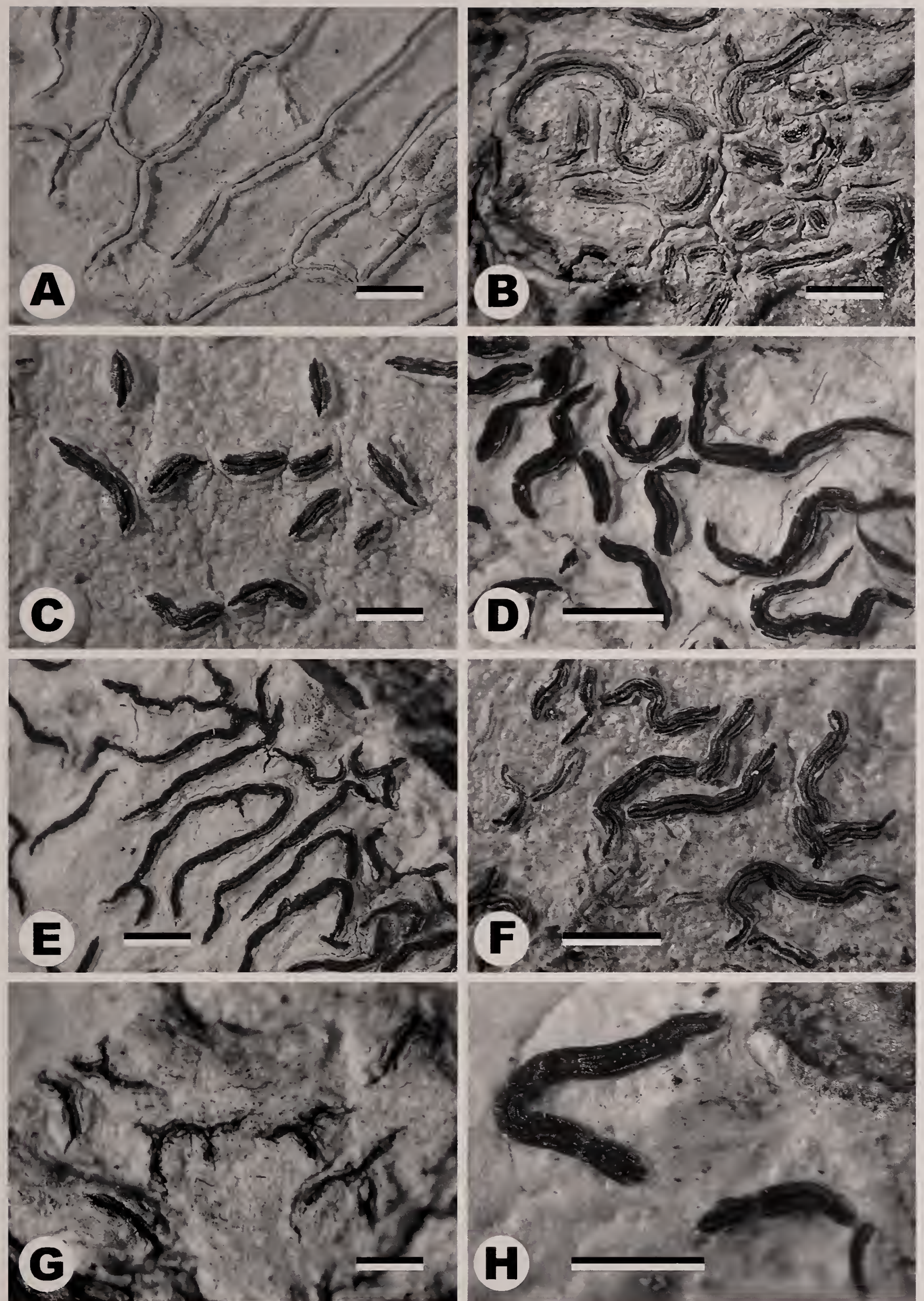

FIG. 8. Species with transversely septate ascospores and apically carbonized excipulum. (A) Graphis glaucescens. (B) Graphis supertecta. (C) Graphis caribica (ascospores medium sized). (D) Graphis chlorotica. (E) Graphis proserpens. (F) Graphis rockii. (G) Graphis vittata (stictic). (H) Graphis stenotera (stictic). Scale $=1 \mathrm{~mm}$. 

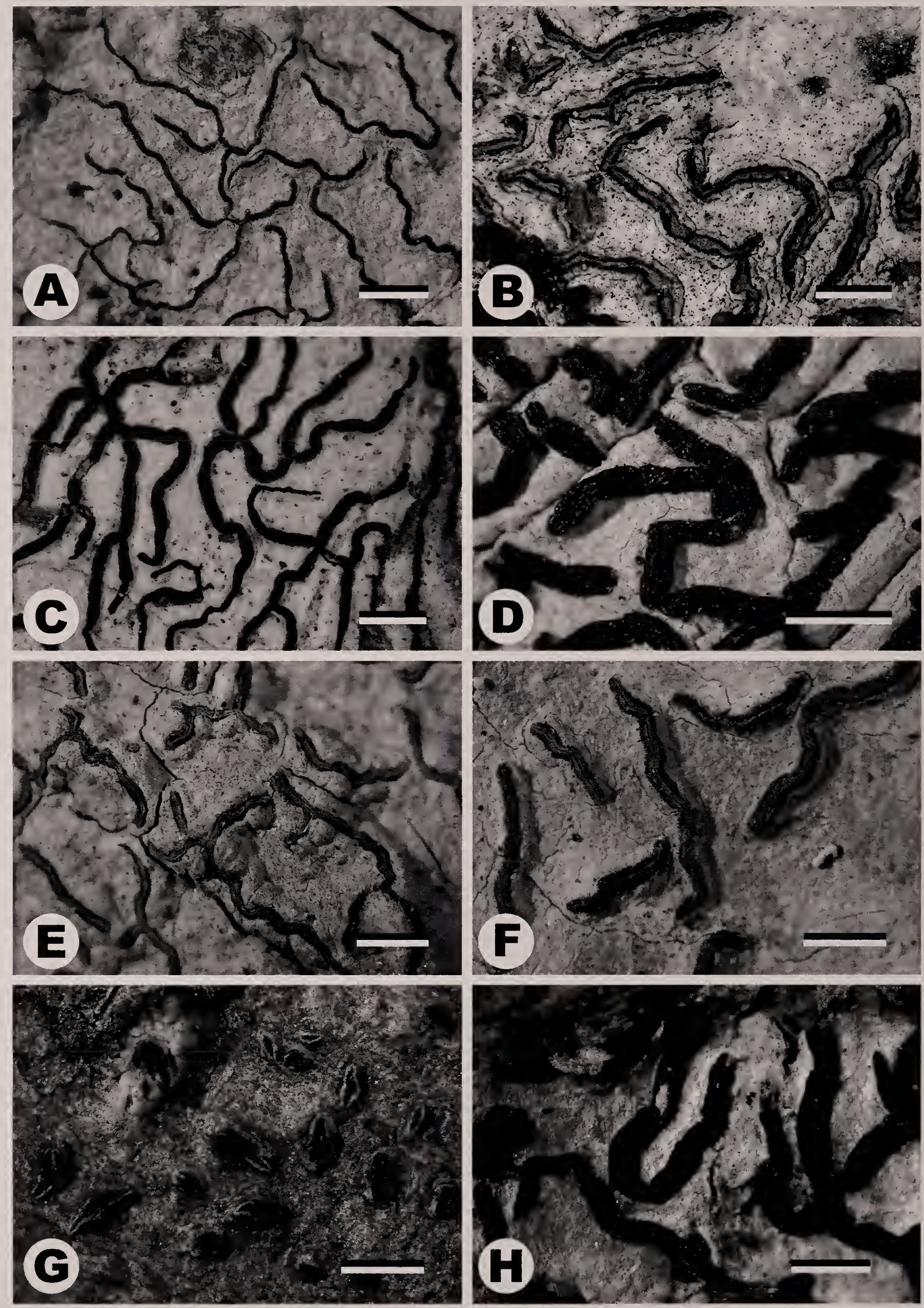

FIG. 9. Species with transversely septate ascospores (small in $\mathbf{A}-\mathbf{D}$, medium sized in $\mathbf{E}-\mathbf{H}$ ) and laterally carbonized excipulum, substances absent. (A) Graphis furcata. (B) Graphis scripta. (C) Graphis tenella. (D) Graphis duplicata. (E) Graphis pavoniana. (F) Graphis farinulenta. (G) Graphis leptoclada. (H) Graphis striatula. Scale = $1 \mathrm{~mm}$. 

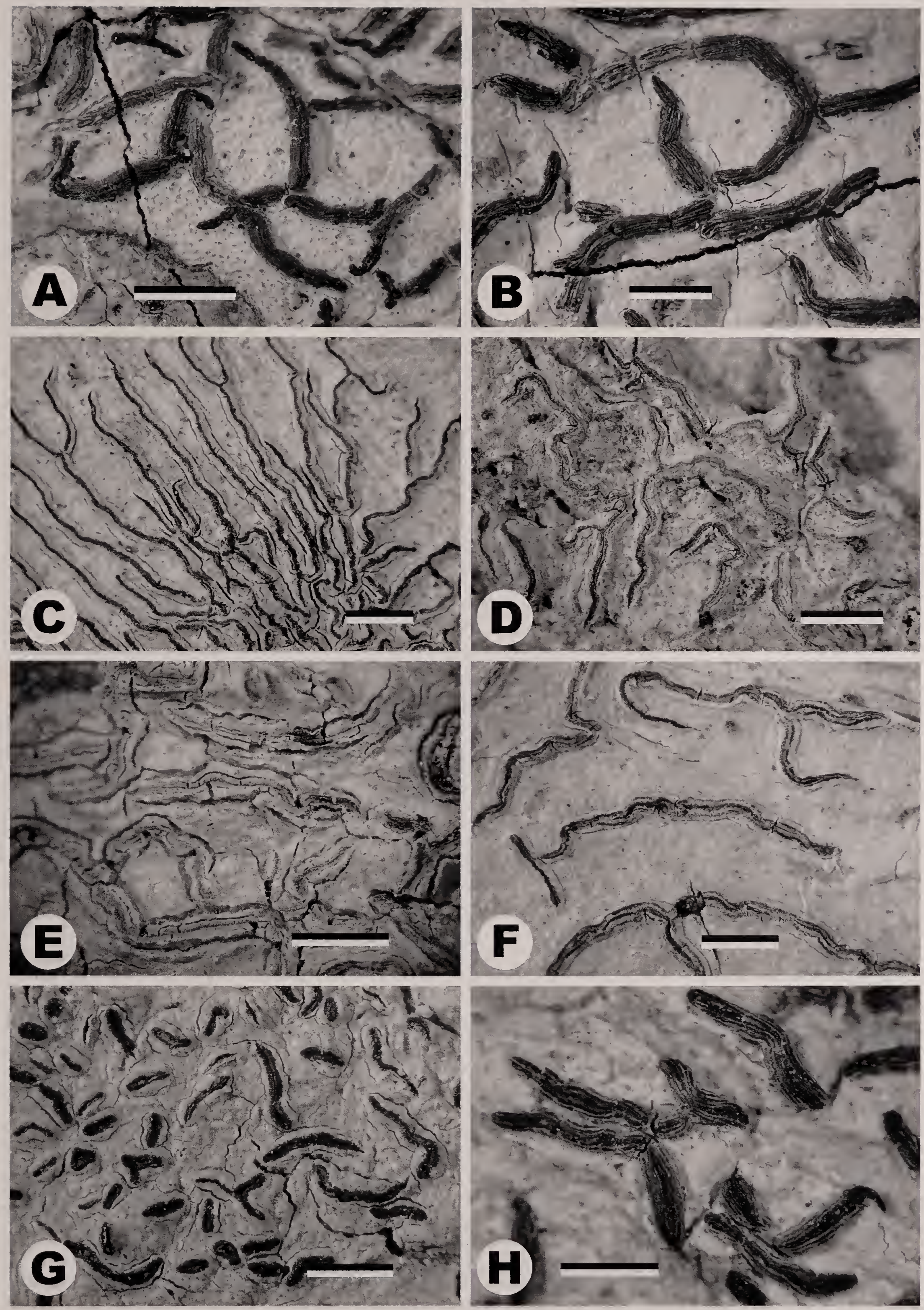

Fig. 10. Species with transversely septate ascospores (small in $\mathbf{A}$ and $\mathbf{C}-\mathbf{G}$, medium sized in $\mathbf{B}$ and $\mathbf{H}$ ) and laterally carbonized excipulum, substances present. (A) Graphis lucifica (lichexanthone). (B) Graphis haleana (lichexanthone). (C) Graphis dendrogramma (stictic). (D) Graphis litoralis (norstictic, salazinic, protocetraric; type). (E) Graphis caesiella (norstictic). (F) Graphis schiffneri (norstictic). (G) Graphis librata (norstictic). (H) Graphis elegans (norstictic). Scale $=1 \mathrm{~mm}$. 

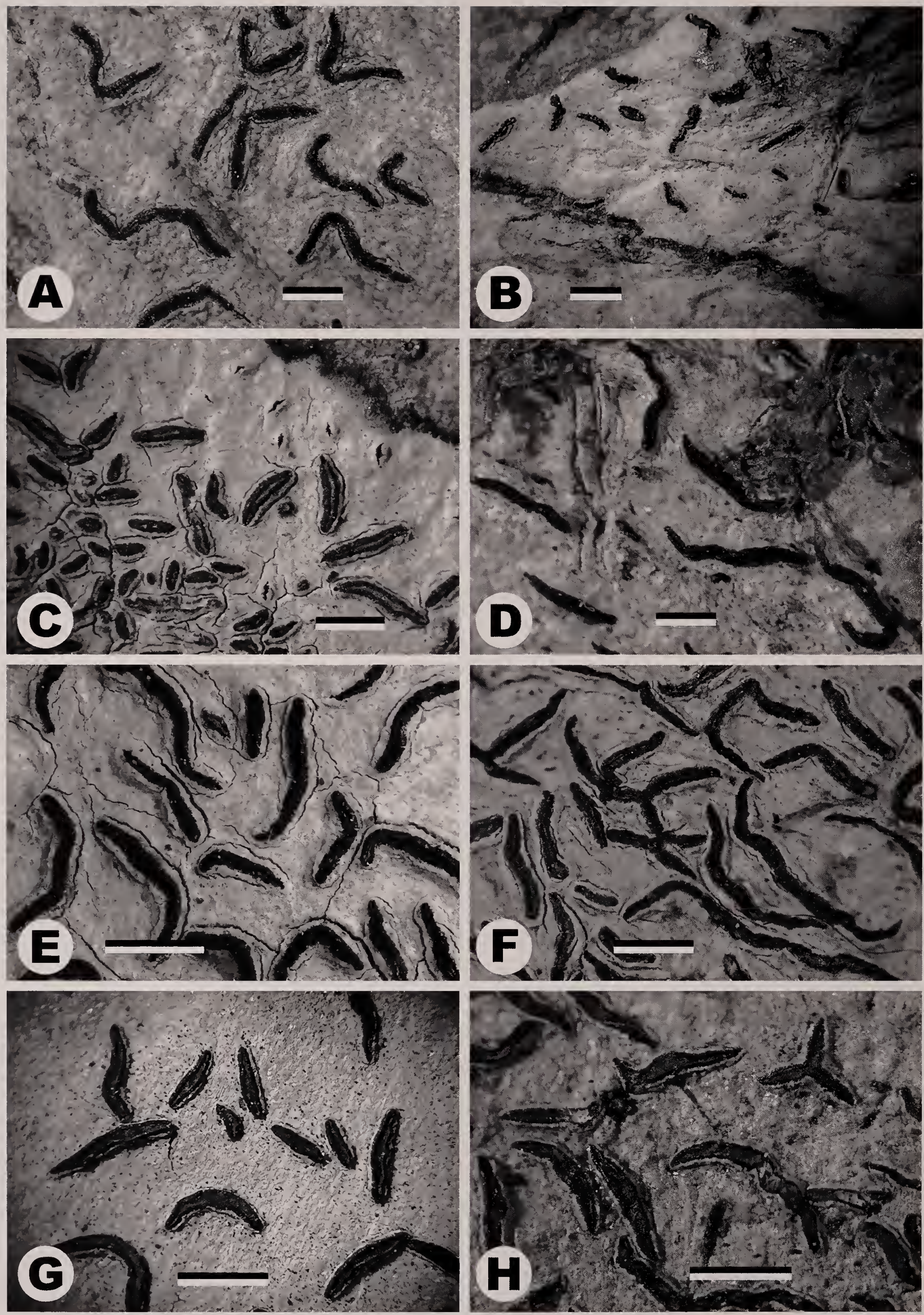

FIG. 11. Species with transversely septate ascospores (small) and laterally carbonized excipulum, hymenium inspersed. (A-B) Graphis lineola (type in B). (C) Graphis submarginata. (D) Graphis duplicatoinspersa (type). (E) Graphis leptocarpa (stictic). (F) Graphis tenellula (norstictic). (G-H) Graphis chondroplaca (norstictic). Scale = $1 \mathrm{~mm}$. 

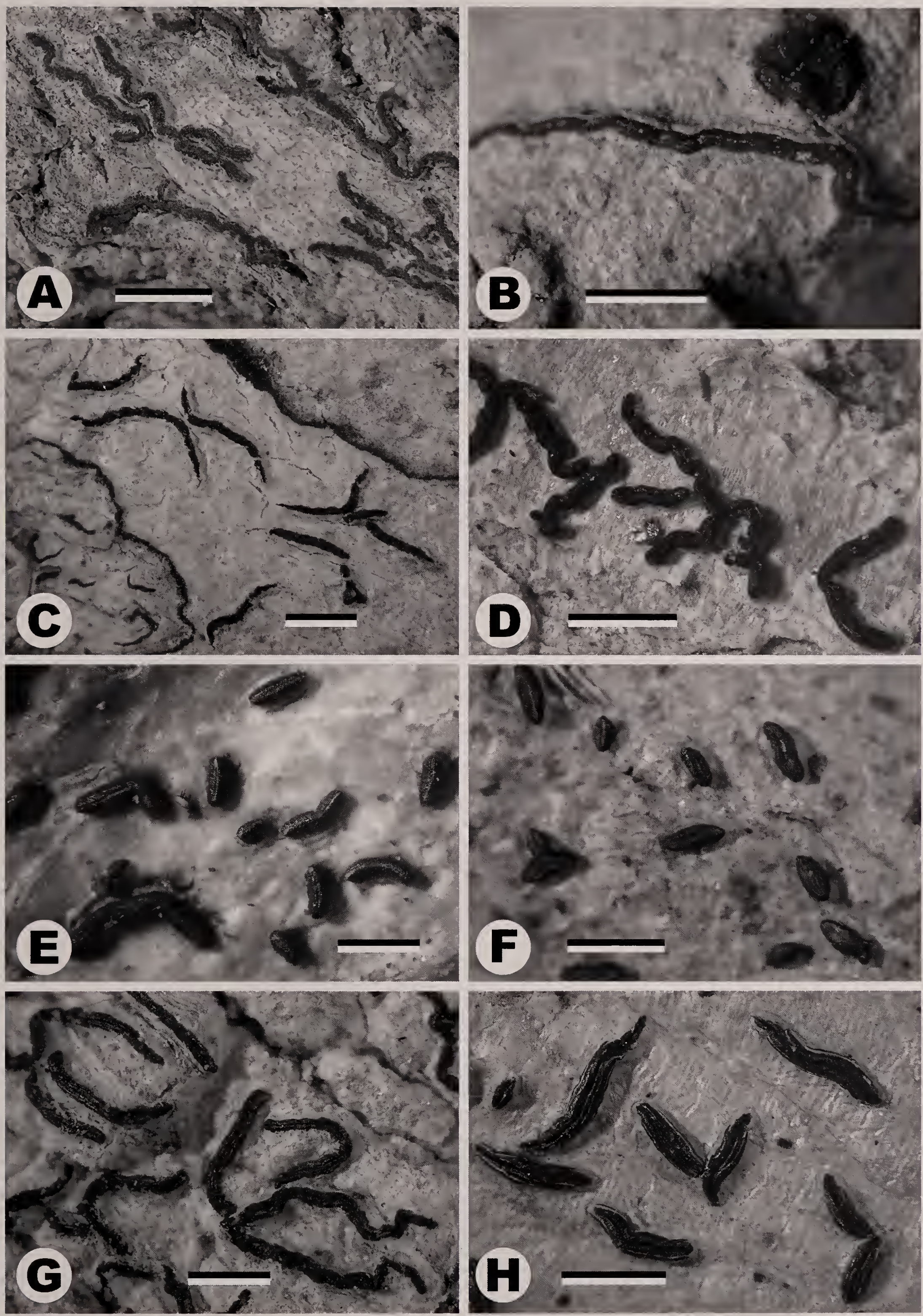

FIG. 12. Species with transversely septate ascospores (small) and completely carbonized excipulum, substances absent. (A) Graphis sitiana. (B) Graphis oxyclada. (C) Graphis dracenae. (D) Graphis geraensis. (E) Graphis virescens. (F) Graphis ovata. (G) Graphis dupaxana. (H) Graphis rimulosa. Scale $=1 \mathrm{~mm}$. 

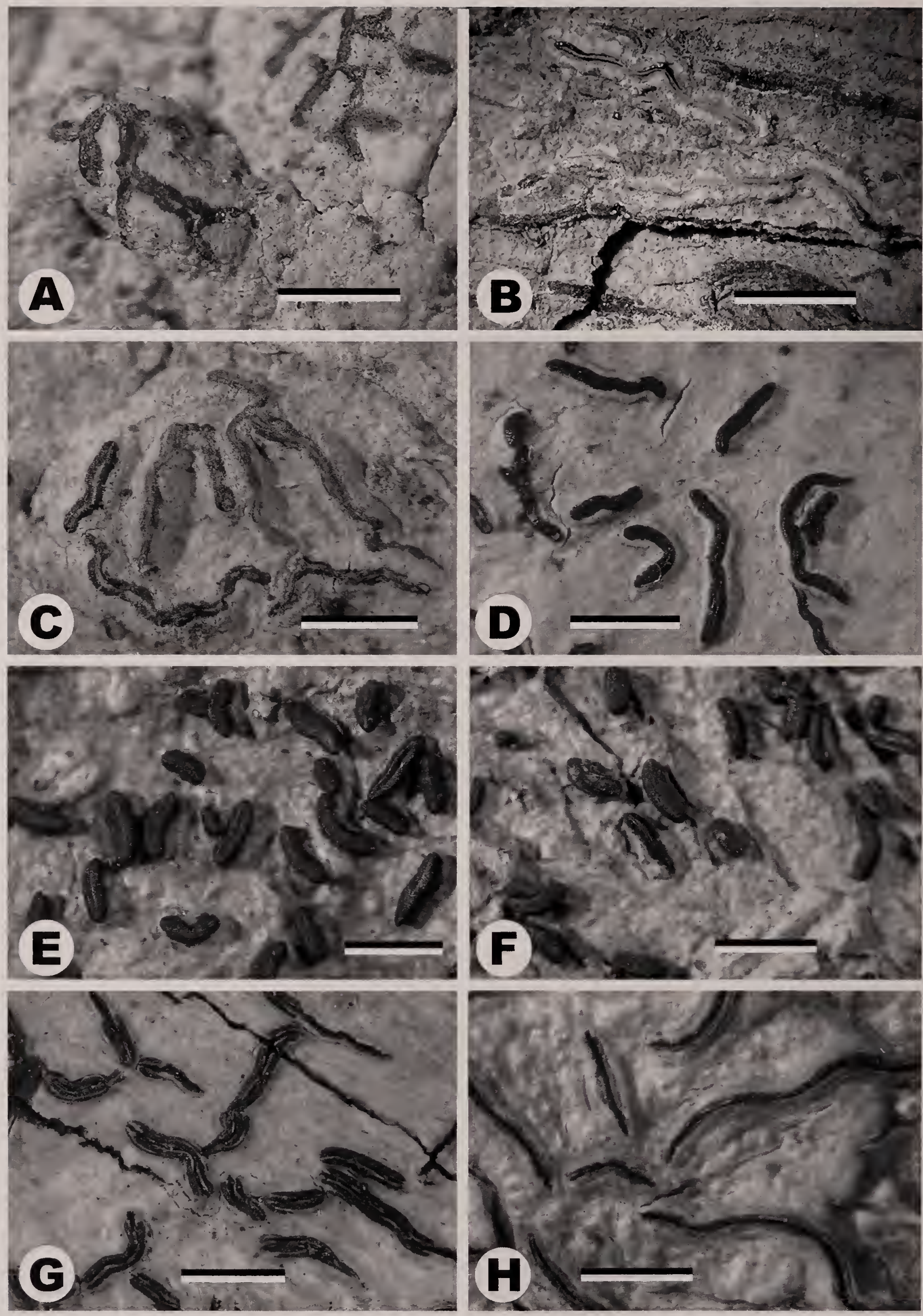

Fig. 13. Species with transversely septate ascospores (small in $\mathbf{A}-\mathbf{B}$, medium sized in $\mathbf{C}-\mathbf{H}$ ) and completely carbonized excipulum (apically and basally carbonized in H), substances absent. (A) Graphis hyphosa (type of $G$. intricata f. meizospora). (B) Graphis subvirginea (syntype). (C) Graphis seminuda. (D) Graphis flavens. (E) Graphis adpressa. (F) Graphis pittieri (ascospores gray-brown; type). (G) Graphis longula. (H) Graphis gregmuelleri (excipulum apically and basally carbonized; type). Scale $=1 \mathrm{~mm}$. 

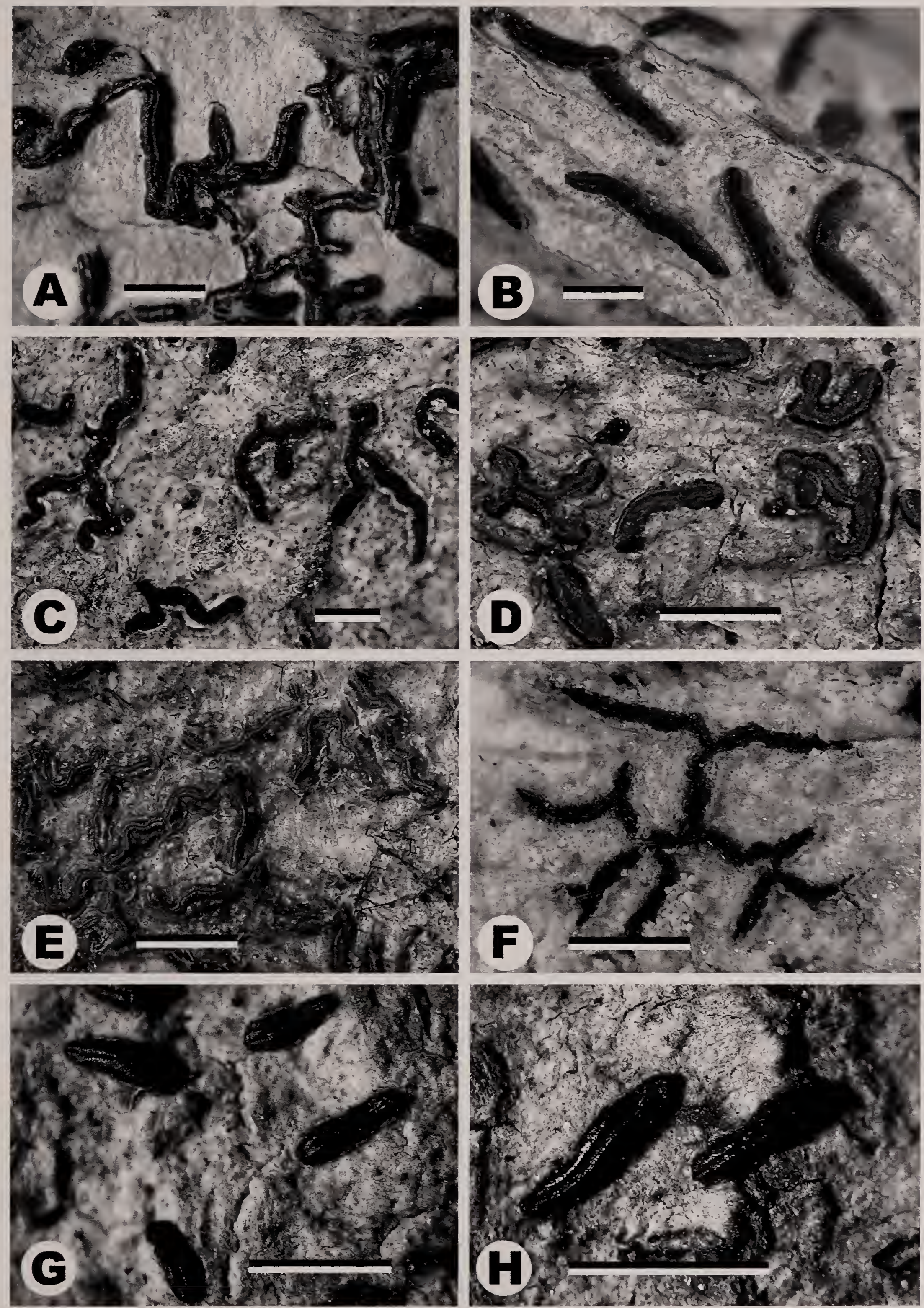

FIG. 14. Species with transversely septate ascospores and completely carbonized excipulum, hymenium inspersed (A-B) or substances present $(\mathbf{C}-\mathbf{H})$. (A-B) Graphis anfractuosa (inspersed; type in A). (C-D) Graphis sauroidea (lichexanthone). (E-F) Graphis caesiocarpa (norstictic; type in E). (G-H) Graphis emersa (norstictic; type). Scale $=1 \mathrm{~mm}$. 

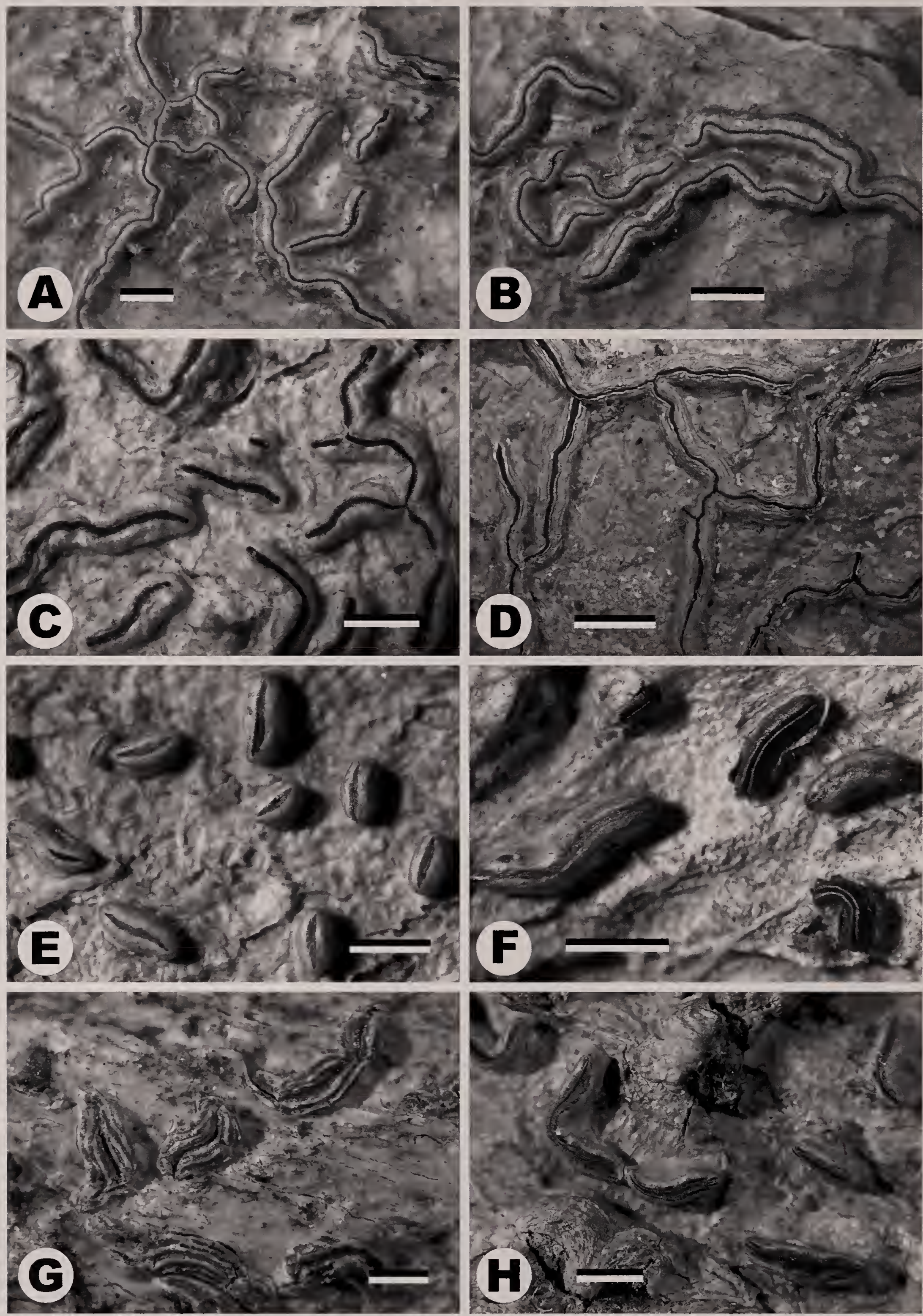

FIG. 15. Species with transversely septate ascospores (large in $\mathbf{A}-\mathbf{G}$, very large in $\mathbf{H}$ ) and completely carbonized excipulum, substances absent. (A-D) Graphis rhizocola (striate morph in D). (E-F) Graphis nudaeformis (detaching thallus cover in F; type). (G) Graphis angustata. $(\mathbf{H})$ Graphis tumidula. Scale $=1 \mathrm{~mm}$. 

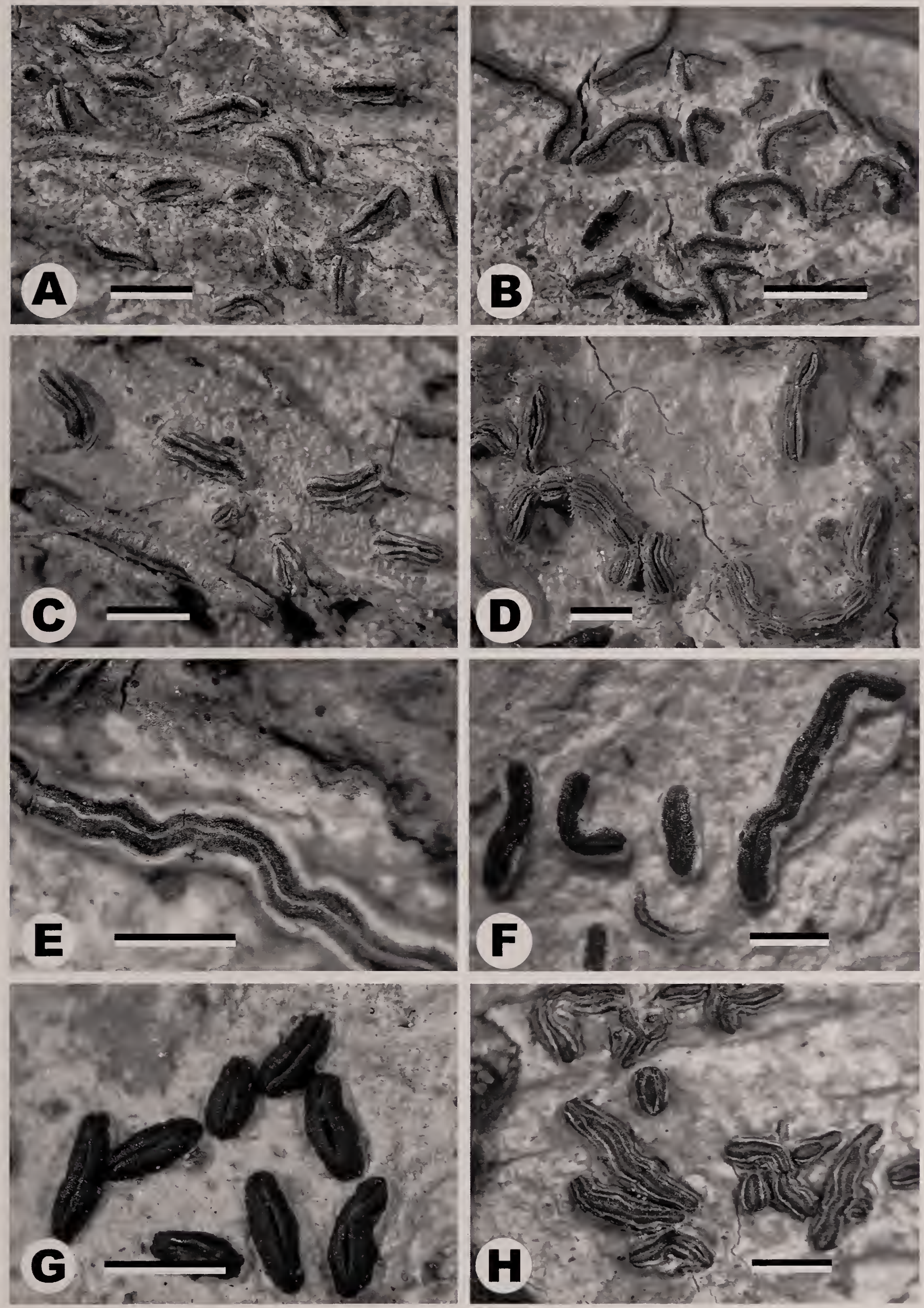

Fig. 16. Species with transversely septate ascospores (large in $\mathbf{A}-\mathbf{B}$ and $\mathbf{E}-\mathbf{H}$, very large in $\mathbf{C}-\mathbf{D}$ ) and completely carbonized excipulum, hymenium inspersed or substances present. (A-B) Graphis bettinae (inspersed; type). (C-D) Graphis cinerea (inspersed). (E) Graphlis marginata (stictic). (F) Graplis rustica (norstictic). (G-H) Graphis lumbricina (norstictic; morphs with entire and striate labia). Scale $=1 \mathrm{~mm}$. 

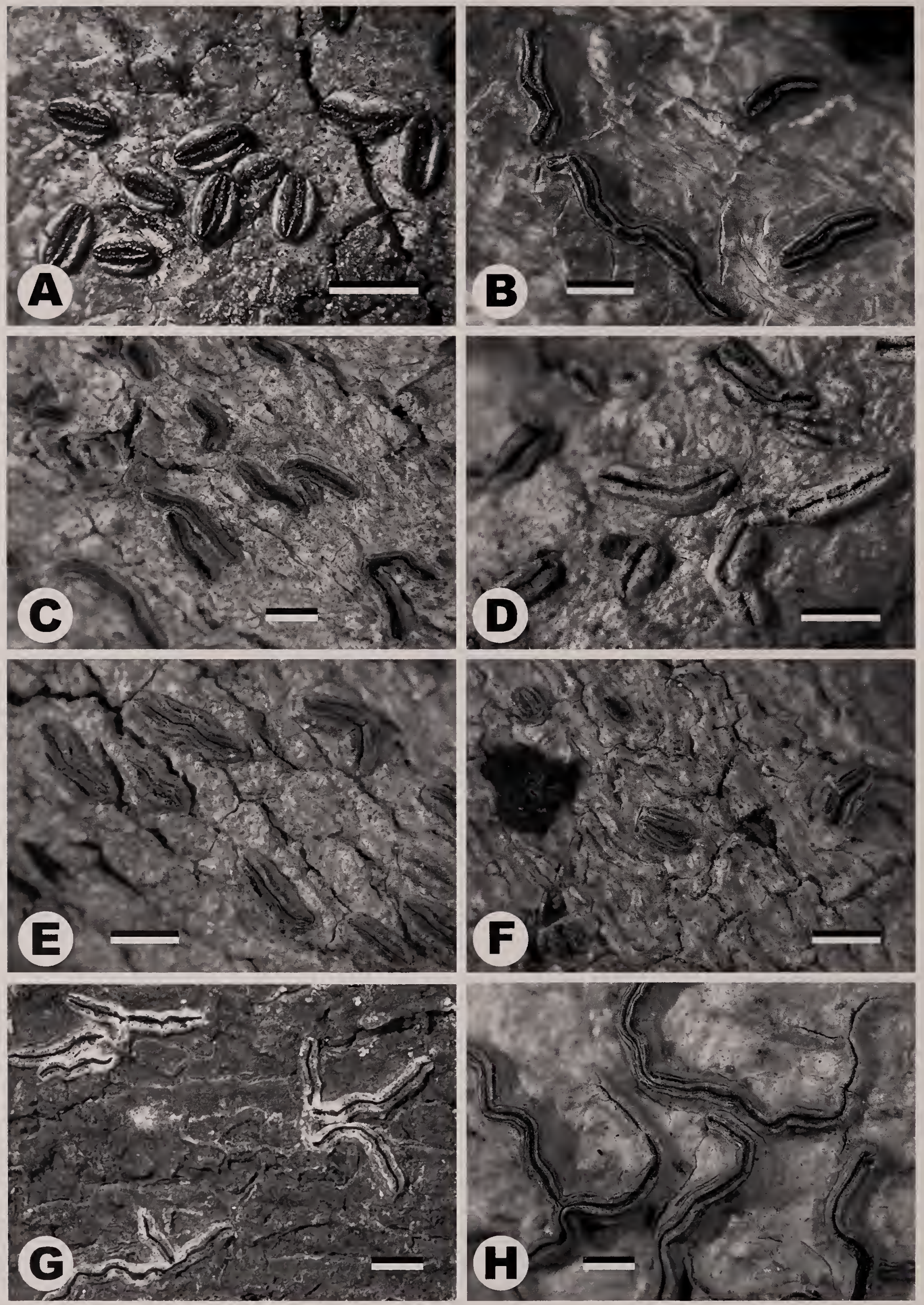

FIG. 17. Species with terminally muriform ascospores (large) and completely carbonized excipulum. (A) Graphis plagiocarpa. (B) Graphis vestitoides. (C-F) Graphis subflexibilis (inspersed; morphs with entire and striate labia). (G) Graphis subturgidula (stictic). (H) Graphis aquilonia (norstictic). Scale $=1 \mathrm{~mm}$. 

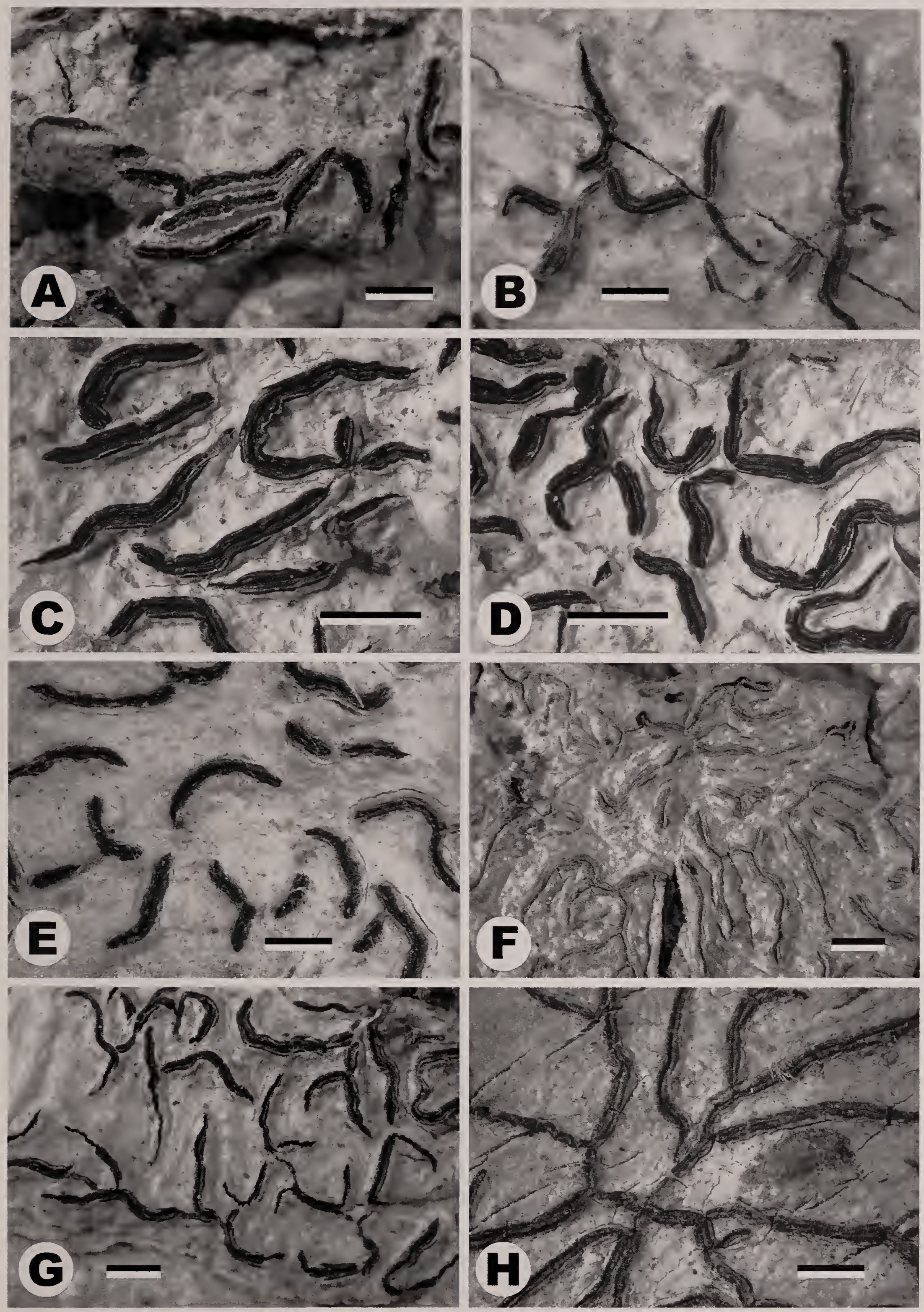

FIG. 18. Species with muriform ascospores (small) and apically carbonized excipulum, substances absent. (A) Graphis dimidiata. (B) Graphis paradisserpens. (C-D) Graphis pseudoserpens (type). (E-F) Graphis syntecta (type in $\mathbf{F})$. $(\mathbf{G}-\mathbf{H})$ Graphis disserpens. Scale $=1 \mathrm{~mm}$. 

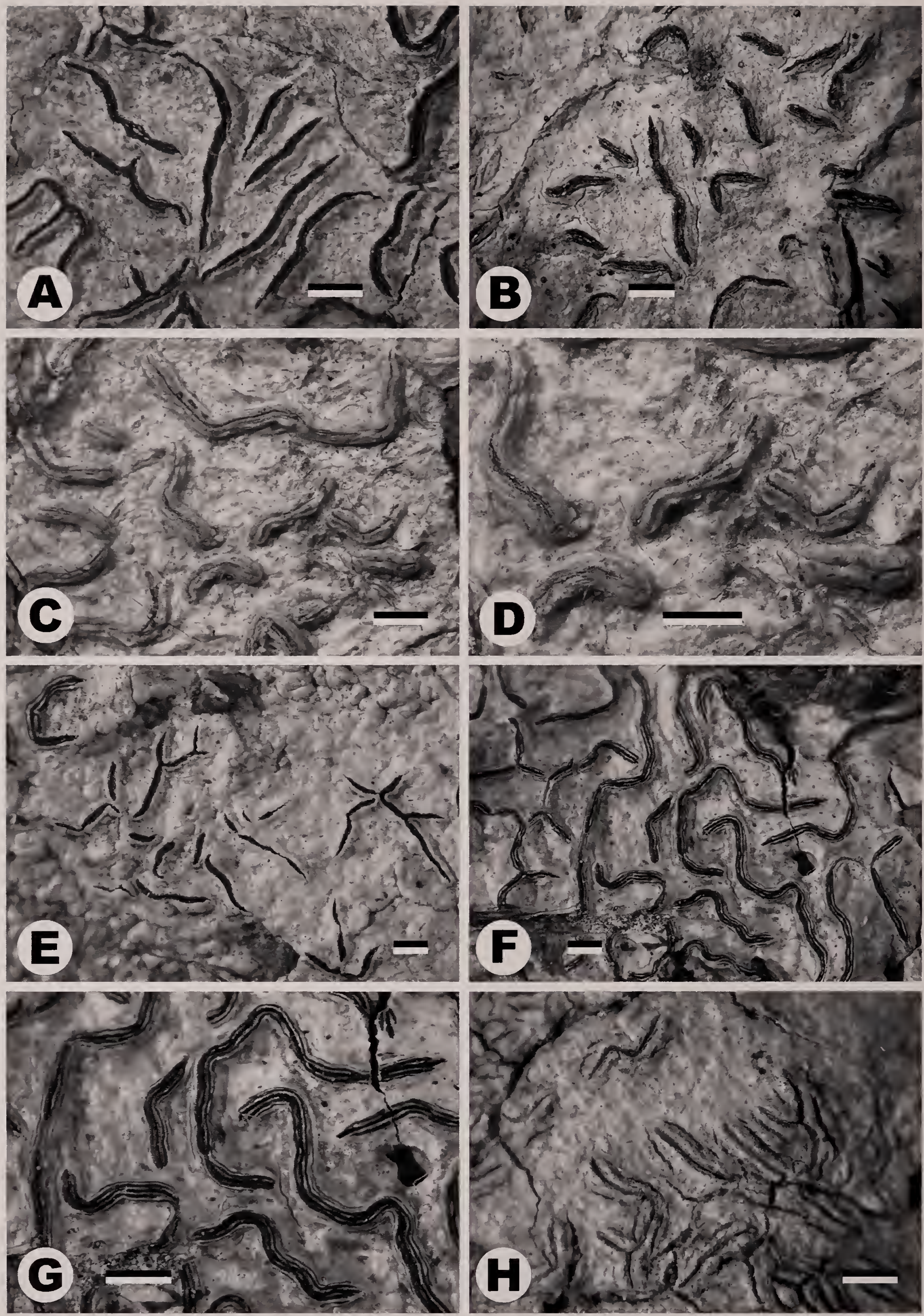

FIG. 19. Species with muriform ascospores (medium sized in $\mathbf{A}-\mathbf{B}$, large in $\mathbf{C}-\mathbf{H}$ ) and apically carbonized excipulum (apically and basally carbonized in $\mathrm{H}$ ), substances absent. (A-B) Graphis platycarpa. (C-D) Graphis mirabilis. (E-G) Graphis tenoriensis (type). (H) Graphis subcontorta. Scale $=1 \mathrm{~mm}$. 

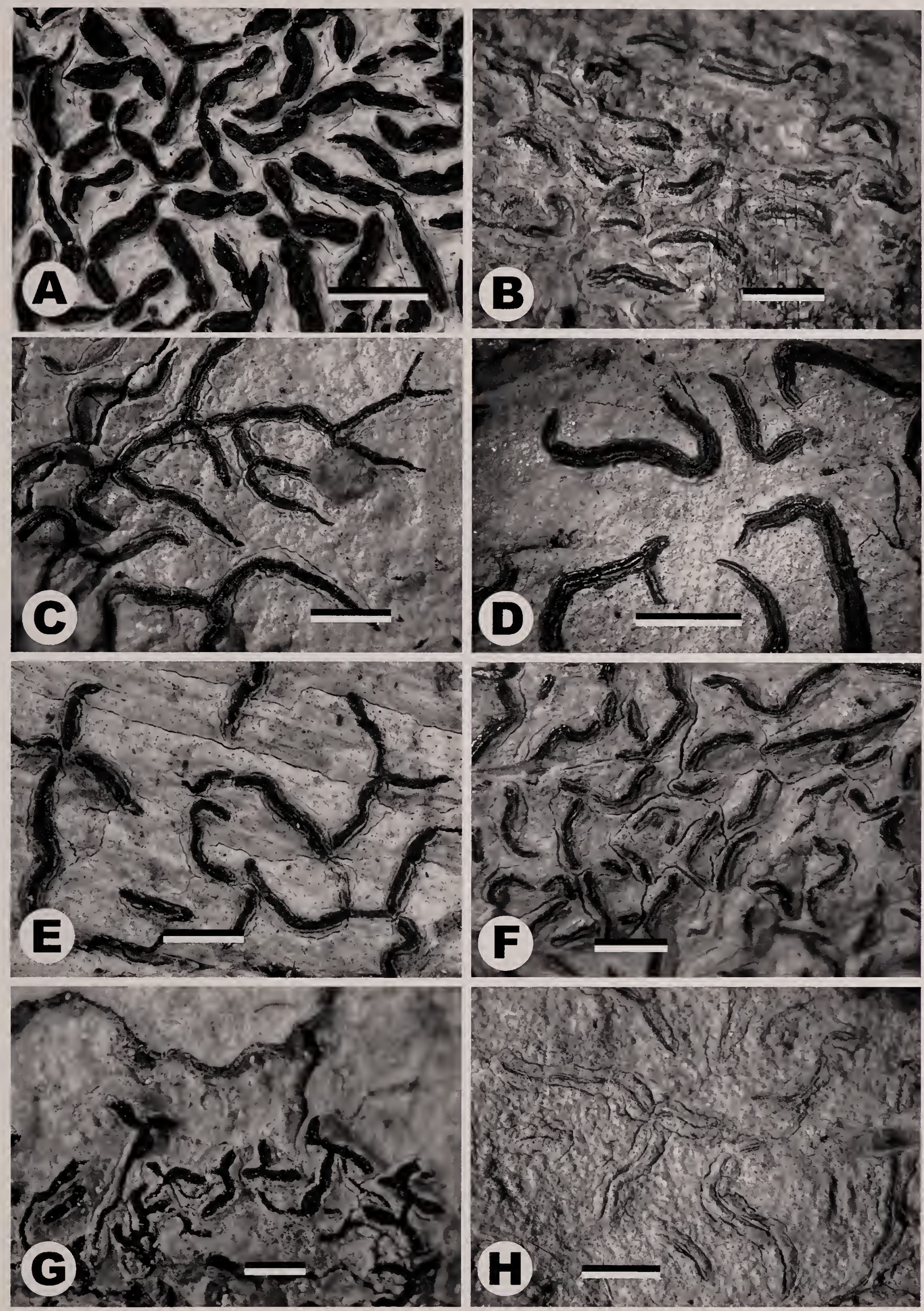

FIG. 20. Species with muriform ascospores (medium sized in $\mathbf{A}-\mathbf{B}$ and $\mathbf{E}-\mathbf{F}$, small in $\mathbf{C}-\mathbf{D}$, large in $\mathbf{G}-\mathbf{H}$ ) and apically carbonized excipulum, substances present. (A-B) Graphis parilis (stictic). (C-D) Graphis perstriatula (norstictic). (E-F) Graphis antillarum (norstictic). (G-H) Graphis bipartita (norstictic; type in $\mathbf{H})$. Scale $=1 \mathrm{~mm}$. 

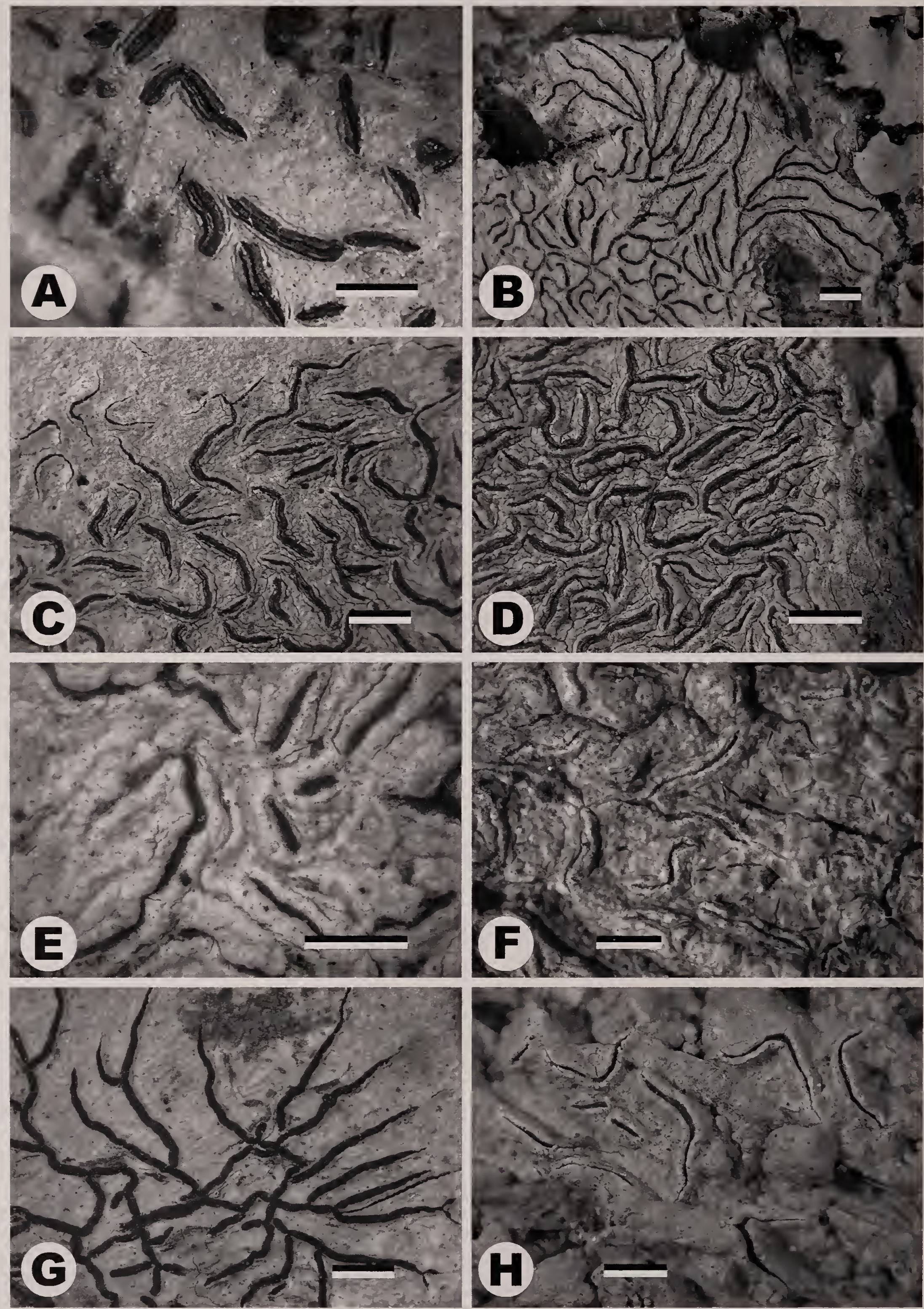

FIG. 21. Species with muriform ascospores (small in $\mathbf{A}-\mathbf{B}$ and $\mathbf{G}$, medium sized in $\mathbf{C}-\mathbf{D}$, large in $\mathbf{E}-\mathbf{F}$ and $\mathbf{H}$ ) and laterally carbonized excipulum, substances absent or present. (A) Graphis puiggarii. (B) Graphis dichotoma. (CD) Graphis paraserpens (type). (E) Graphis xylophaga. (F) Graphis subhiascens. (G) Graphis gracilis (norstictic). (H) Graphis insulana (inspersed, norstictic). Scale $=1 \mathrm{~mm}$. 

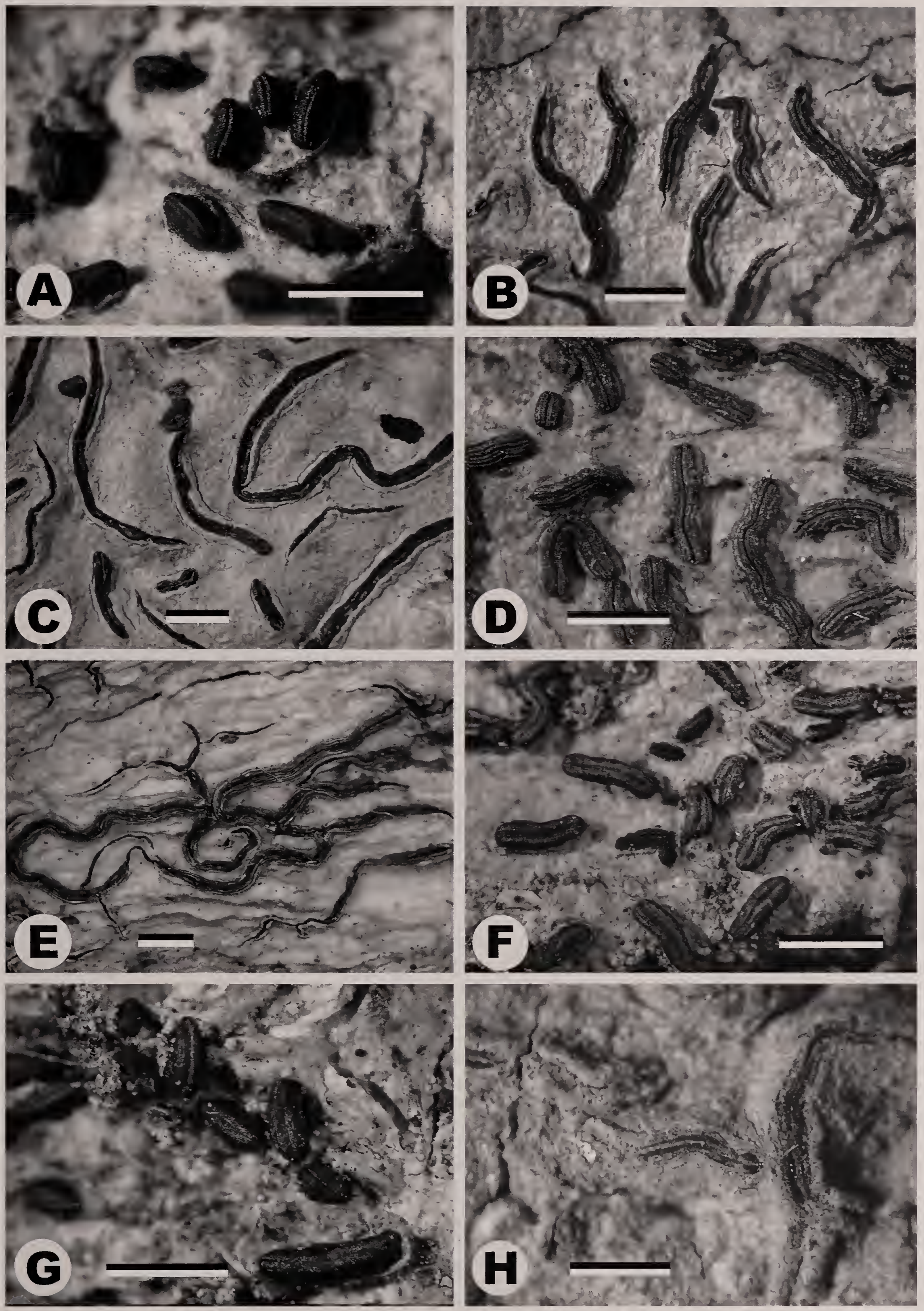

FIG. 22. Species with muriform ascospores (small in $\mathbf{A}$, medium sized in $\mathbf{B} \mathbf{G}$, large in $\mathbf{H}$ ) and completely carbonized excipulum, substances absent. (A) Graphis nuda. (B) Graphis plurispora (ascospores narrow). (C) Graphis gomezii (type). (D) Graphis fournierii (thallus yellow-green; type). (E) Graphis multisulcata (ascospores broad). (F) Graphis ruiziana. (G) Graphis subruiziana (type). (H) Graphis inturgescens (type). Scale $=1 \mathrm{~mm}$. 

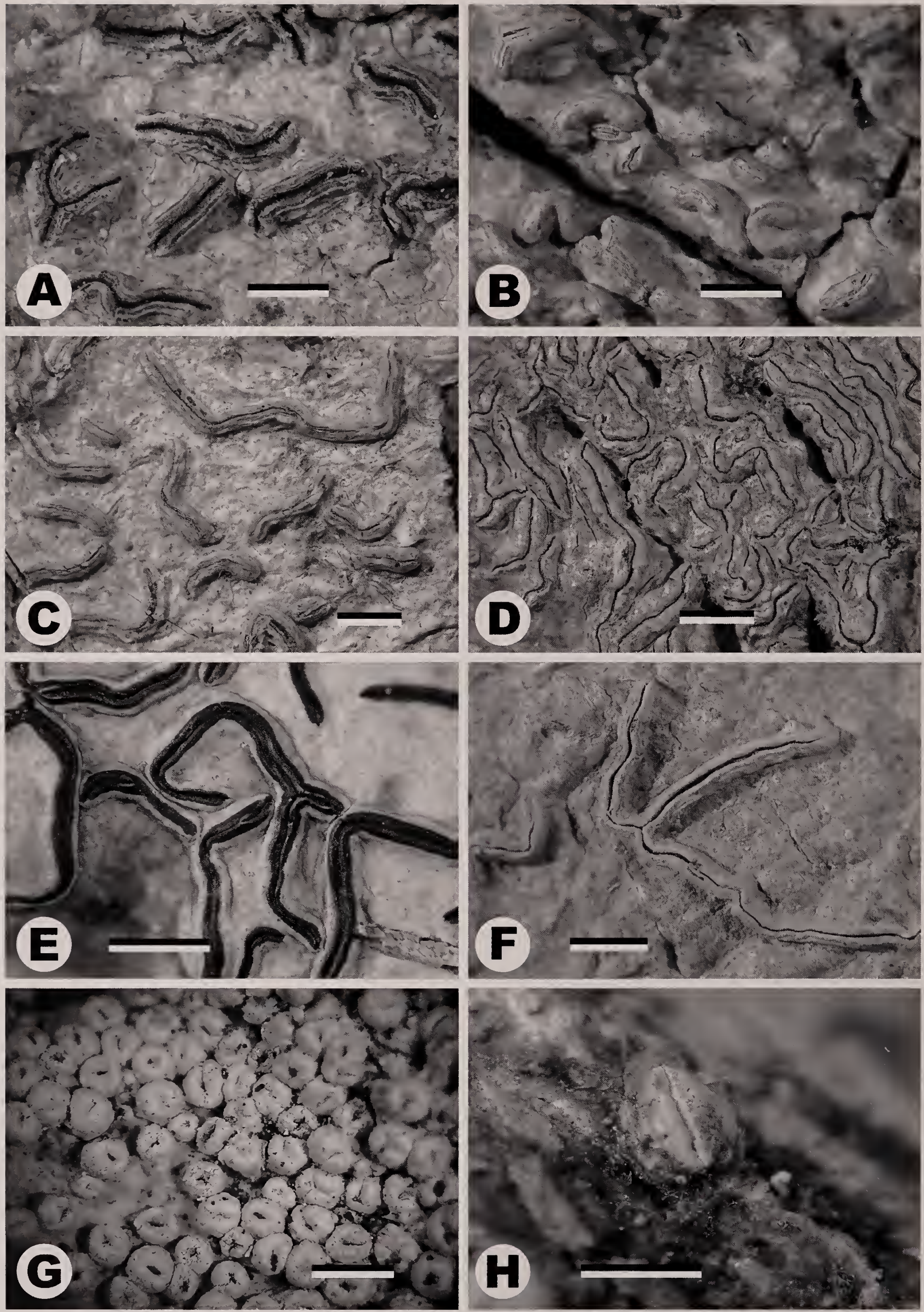

FIG. 23. Species with muriform ascospores (large) and completely carbonized excipulum, substances absent (A) Graphis acharii (2-6/ascus). (B) Graphis carassensis (1-3/ascus). (C) Graphis macella (1/ascus). (D) Graphis consanguinea (1/ascus). (E) Graphis myrtacea (1/ascus). (F) Graphis illinata (1/ascus). (G) Graphis mexicana (1-2/ ascus). (H) Graphis oryzaecarpa (1-2/ascus). Scale $=1 \mathrm{~mm}$. 

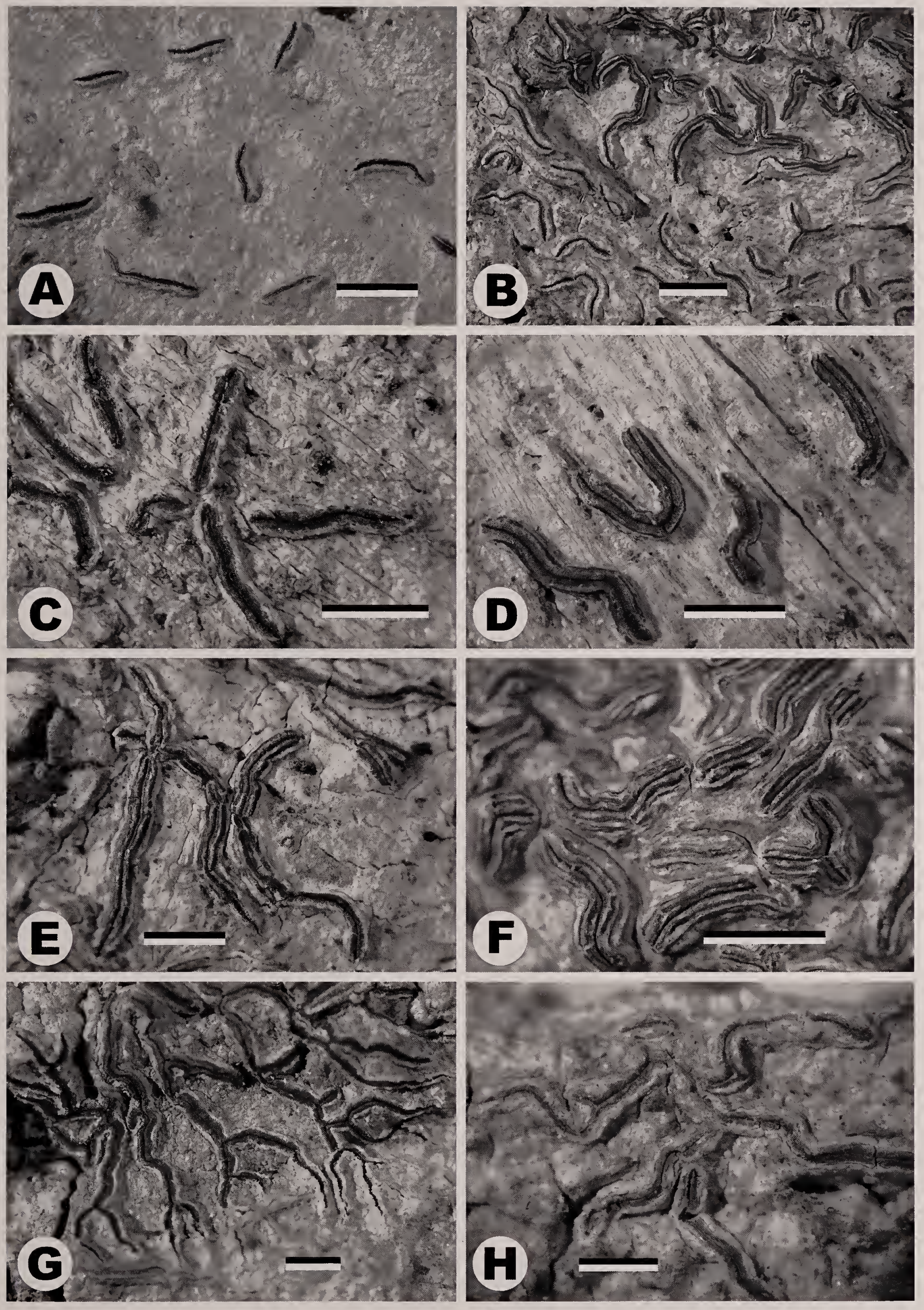

Fig. 24. Species with muriform ascospores (medium sized in $\mathbf{A}$, large in $\mathbf{B}-\mathbf{F}$ and $\mathbf{H}$, very large in $\mathbf{G}$ ) and completely carbonized excipulum, hymenium inspersed, substances absent. (A) Graphis pseudocinerea (type). (B-F) Graphis argentata (ascospores narrow; morphs with entire and striate labia). (G) Graphis altamirensis (ascospores narrow). (H) Graphis plaeospora (ascospores broad). Scale $=1 \mathrm{~mm}$. 

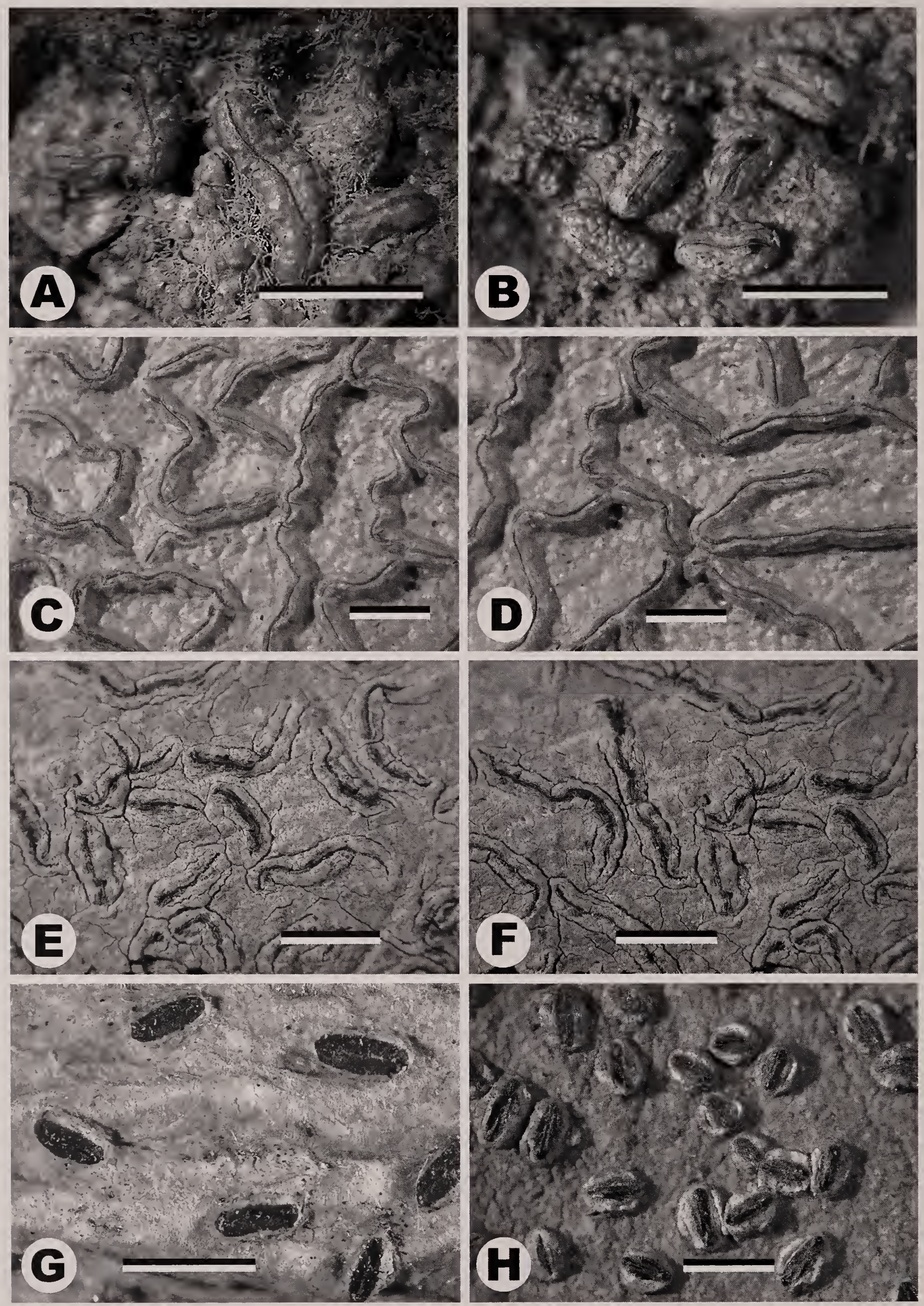

FIG. 25. Species with muriform ascospores (large) and completely carbonized excipulum, substances present. (A-B) Graphis granulosa (hypostictic). (C-D) Graphis inspersostictica (stictic). (E-F) Graphis leprographa (norstictic). (G-H) Graphis cleistoblephara (norstictic). Scale $=1 \mathrm{~mm}$. 
and chemical features (see the section Key to Image Plates above). Therefore, the sequence of taxa in the illustrations does not follow the sequence of taxa in the text.

\section{Graphis Adans.}

Graphis Adans., Fam. Pl. II: 11. 1763. Type. Graphis scripta (L.) Ach.

Opegrapha Humb., Fl. Fribergensis: 57. 1793 [nom. rej., non Opegrapha Ach.]. Type. Opegrapha vulgaris Humb. [nom. illeg., ICBN Art. 52.1] = Graphis scripta (L.) Ach.

Scaphis Eschw., Syst. Lich.: 14. 1824. Lectotype (fide Staiger, 2002: 181). Scaphis anfractuosa Eschw. $\equiv$ Graphis anfractuosa (Eschw.) Eschw.

Allographa Chevall., Histoire des Graphidées: XVI, fig. 3d, e. 1824. Lectotype (fide Staiger, 2002: 181). Allographa lutea Chevall. = Graphis lutea (Chevall.) Aptroot.

Ctesium Pers. in Gaudichaud-Beaupré, Botanique du Voyage Autour du Monde: 185. 1827. Lectotype (fide Staiger, 2002: 181). Ctesium croceum Pers. [nom. illeg., ICBN Art. 52.2(e)]. = Graphis chrysocarpa (Raddi) Spreng.

Aulacographa Leight., Ann. Mag. Nat. Hist., Ser. 2, 13: 389. 1854. Type. Aulacographa elegans (Sm.) Leight. $\equiv$ Graphis elegans (Sm.) Ach.

Schistostoma Stirt., Proc. Roy. Philos. Soc. Glasgow 11: 312. 1879. Type. Schistostoma dehiscens Stirt. = Graphis chondroplaca (Redinger) Lücking.

Graphina Müll. Arg., Flora 63: 22. 1880. Lectotype (fide Lücking et al., 2007c: 1297): Graphina puiggarii Müll. Arg. $\equiv$ Graphis puiggarii (Müll. Arg.) Lücking.

Graphidomyces Cif. \& Tomas., Atti Ist. Bot. Lab. Crittog. Univ. Pavia, Ser. 5, 10: 50, 75. 1953; nom. illeg. ICBN Art. 10, 52.1, 52.2 (see Lücking \& Hawksworth, 2007). Type. Graphidomyces elegantis Cif. \& Tomas. [nom. illeg., ICBN Art. 52.1, 52.2]. $\equiv$ Graphis elegans (Sm.) Ach.

REMARKS-Graphina is here listed as a new synonym of Graphis and not of Thalloloma as given by Staiger (2002) since the lectotypification with Ustalia anguina Mont. [ $\equiv$ Thalloloma anguinum (Mont.) Trevis.] performed by Hawksworth and Sherwood (1981) was incorrect (Lücking et al., 2007c). Both of Müller Argoviensis's (1880a,b) "Lichenologische Beiträge" X include the description of Graphina (no. 143) and list 13 species as belonging to the new genus, including G. montagnei, the type of the previously established genus Pliariona A. Massal. In the Cramer reprint (Müller Argoviensis, 1967), this work appears as a single publication, based on which Graphina would be illegitimate according to ICBN Art. 52.1 and 52.2 since it definitely includes the type of a previously established genus. However, in the original publication in Flora 63, the work was split after no. 146, and thus, the second part (nos. 147-165), which included G. montagnei, is formally a separate publication appearing 10 days later and hence not part of the protologue. This also means that a lectotype can be selected only from the three species mentioned in the first part (the effective protologue). Müller Argoviensis (1880a) did not cite $G$. anguina when he originally established Graphina; instead, he made the combination in a subsequent paper. In conclusion, Graphina is a legitimate name, with originally three species that all belong in Graphis sensu Staiger (2002). It was lectotypified with $G$. puiggarii and thus is a heterotypic synonym of Graphis (Lücking et al., 2007c).

Even after the generic revision of Graphidaceae by Staiger (2002), Graphis remains by far the largest genus within the family, with possibly $300+$ species worldwide. The large number of species is due to the combination of a few character complexes, such as lirellae morphology (emergence: four types; thalline margin: four types), excipulum structure (carbonization: three types; striation: two types), hymenial inspersion (clear versus inspersed), ascospore type (three size classes by two septation types: transverse versus muriform, plus terminally muriform), and secondary chemistry (nil and four major compounds). Assuming a schematic categorization of these seven character complexes into their main states, the total number of free combinations is $4 \times 4 \times 3 \times 2 \times 2 \times 7 \times 5=6720$. This does not include character complexes such as thallus cortex, labia pruinosity, concealed versus exposed discs, or pigments, suggesting that the total number of free combinations is well beyond 10,000 . The fact that "only" $300+$ combinations exist suggests a high level of correlation between certain character states, underlying their importance for distinguishing species and species groups. Phenotype-based phylogenetic analysis indeed shows that most groups have "preferred" character states (Lücking 2008b), but the relatively large number of intermediate taxa and the small number of characters separating the different groups indicate that further division of Graphis into several smaller genera might not be feasible.

\section{Graphis acharii Fée. Figure 23A.}

Graphis acharii Fée, Essai Crypt. Écorc.: 39. 1824; Graphina acharii (Fée) Müll. Arg., Mém. Soc. Phys. Genève 29(8): 38. 1887. Holotype. South America, unknown locality, s.dat., s.col. (G, not seen). 
Graphis curta Fée, Bull. Soc. Bot. Fr. 21: 27. 1874. Holotype. Brazil, Glaziou 5486 (G!).

Graphina tuberculifera Müll. Arg., J. Linn. Soc. Bot. 30: 458. 1895. Holotype. Brazil, Glaziou 11777 (G!).

Graphina pachypleura Müll. Arg., J. Linn. Soc. Bot. 30: 459. 1895. Holotype. Brazil, Glaziou 16671 (G!).

DiagnOSIS-Thallus corticate, smooth to uneven, white-gray. Lirellae prominent, partly branched, with (apically thin) complete thalline margin, 1-10 $\mathrm{mm}$ long, 0.5-1 $\mathrm{mm}$ broad; labia striate (entire in first-generation lirellae). Excipulum completely carbonized. Hymenium clear. Ascospores 2-6 per ascus, muriform, 80-170 $\times$ 15-30 $\mu \mathrm{m}$, hyaline. Secondary chemistry: no substances detected by TLC.

REMARKS - One of the most common and widespread species in the genus, recognized by its prominent, soon striate lirellae with complete thallus cover and completely carbonized excipulum, 2-6-spored asci and large muriform ascospores. Based on Wirth and Hale (1978), Staiger (2002) listed Graphis inturgescens Kremp. as synonym, and Wirth and Hale (1978) also indicated $G$. acharii var. subintegra as conspecific. The two differ from $G$. acharii chiefly in the entire labia; however, there are also differences in morphological and anatomical details that suggest a close relationship of $G$. inturgenscens with G. illinata, a member of the G. rhizocola group (see below). Graphis phaeospora Vain. was also listed as synonym of $G$. acharii by Staiger (2002); however, it has a strongly inspersed hymenium and represents a distinct species (see below). The type materials of G. curta, Graphina tuberculifera, and $G$. pachypleura have striate labia and also otherwise agree well with $G$. acharii. Graphina tuberculifera has a strongly uneven thallus but does not produce real verrucae; $G$. pachypleura was described as having singlespored asci and hence would be conspecific with Graphis macella, but examination of the type material revealed (1-)2-6-spored asci. Most closely related to Graphis acharii is G. vestitoides, which differs only in its terminally instead of regularly muriform ascospores. Graphis macella has single-spored asci.

Graphis acharii was reported from Costa Rica by Breuss (2004). Dodge identified a typical specimen at FH as Graphina pseudanaloga (Vain.) Zahlbr., another as Graphis platycarpella Müll. Arg (a taxon which belongs in Fissurina), and a further one as G. tenuescens Nyl.

SpeCimens SeEN-COSTA RICA. Alajuela: Between Desamparados and Alajuela, $920-980 \mathrm{~m}$, road- side, 6 Oct 1929, Dodge \& Valerio 4888 (FH). Colinas de San Pedro de San Ramón, 30 Jul 1933, Brenes 9 $(\mathrm{FH})$. Miravalles Protection Zone, Altamira Section (Arenal Conservation Area), $600-700 \mathrm{~m}, 10^{\circ} 44^{\prime} \mathrm{N}$, $85^{\circ} 05^{\prime} \mathrm{W}, 8$ Aug 2003, Chaves 1055 (INB). San Pedro de San Ramón, 800 m, 26 Feb 1930, Brenes 26 (FH). San Ramón, Feb 1931, Brenes 14477 (FH). Santiago de San Ramón, 1000 m, 24 Dec 1929, Brenes 248 (FH). Volcán Tenorio National Park, Pilón Biological Station (Arenal-Tempisque Conservation Area), Tilarán Ridge, $84^{\circ} 59^{\prime} \mathrm{W}, 10^{\circ} 43^{\prime} \mathrm{N}, 700 \mathrm{~m}$, lower montane cloud forest zone, exposed trees and fence posts along pasture, on bark (lower stem), 15 Mar 2004, Lücking 17208 e (CR, INB, USJ); on bark (lower trunk), 15 Mar 2004, Aptroot 60442 (ABL, INB). Cartago: Cerro Carpintera, 1320-1700 m, 1 Nov 1929, Dodge \& Thomas $4776(\mathrm{FH})$. Lower slopes of La Carpintera, 14 Aug 1925, Dodge 4064 (FH). Río Pacuare Forest Reserve, Barbilla Station (La Amistad Caribe Conservation Area), $500-600 \mathrm{~m}, 9^{\circ} 58^{\prime} \mathrm{N}, 83^{\circ} 27^{\prime} \mathrm{W}, 13 \mathrm{Feb}$ 2003, Chaves 339 (INB). SW slope of Volcán Turrialba, $\mathrm{N}$ of Santa Cruz, slope with forest relics $\mathrm{N}$ of Bonilla Arriba, $83^{\circ} 42^{\prime} \mathrm{W}, 10^{\circ} 01^{\prime} \mathrm{N}, 1500 \mathrm{~m}$, epiphyte in forest, 14 Mar 1985, Sipman 20441 (B, CR). Tapantí National Park (La Amistad Pacífico Conservation Area), trail to waterfall, $1400-1500 \mathrm{~m}, 9^{\circ} 44^{\prime} \mathrm{N}, 83^{\circ} 47^{\prime} \mathrm{W}, 2 \mathrm{Apr}$ 2003, Chaves 500 (INB). Tapantí National Park, Tapantí Section, Tapantí Station (La Amistad Pacífico Conservation Area), Talamanca Ridge, $83^{\circ} 47^{\prime} \mathrm{W}$, $9^{\circ} 45^{\prime} \mathrm{N}, 1300-1400 \mathrm{~m}$, montane rain forest zone, closed primary forest and roadside, on bark (lower stem), 2 Apr 2003, Lücking 16594 (F, INB); $83^{\circ} 48^{\prime} \mathrm{W}$, $9^{\circ} 46^{\prime} \mathrm{N}, 1150 \mathrm{~m}$, montane rain forest zone, living fence trees along roadside pasture, on bark (lower stem), 2 Apr 2003, Lücking 16600 (F), Lücking 16602 (F). Puntarenas: La Amistad International Park, Altamira Station (La Amistad Pacífico Conservation Area), Talamanca Ridge, $83^{\circ} 00^{\prime} \mathrm{W}, 9^{\circ} 02^{\prime} \mathrm{N}, 1500-1600 \mathrm{~m}$, montane rain forest zone, disturbed primary forest and secondary vegetation dominated by Cecropia, on bark (lower trunk), 30 Jun 2002, Sipman 48018a (B, INB), $48022 d$ (B, INB), $48028 a$ (B, INB). Las Cruces Biological Station and Wilson Botanical Garden near San Vito, 900-1000 m, montane rain forest zone, planted vegetation and disturbed forest, 10-24 Oct 2004, Lücking 18046 (F); 16 Oct 2004, Mercado 9 (INB, PR), 11 (INB, PR), Pérez Pérez CR-2000 (INB). Las Tablas Protection Zone, Cedro Ridge, Las Alturas Station (Lä Amistad Pacífico Conservation Area), Talamanca Ridge, $82^{\circ} 50^{\prime} \mathrm{W}, 8^{\circ} 57^{\prime} \mathrm{N}, 1500 \mathrm{~m}$, lower montane rain forest zone, reforestation plot (Cedrela odorata) bordering pasture, on bark (lower trunk), 26 Jun 2002, Lücking 15091 a (F, INB). San José: Sabanilla de Montes de Oca, San José, close to river that divides Sabanilla, 24 Aug 1986, Monge-Nájera s.n. (B, UsJ).

Graphis adpressa Vain. Figures 5C, 13E.

Graphis adpressa Vain., Acta Soc. Fauna Fl. Fenn. 7: 119. 1890. Lectotype (fide Wirth \& Hale, 1978: 10). Brazil, Vainio s.n. (TUR-Vainio 27851! Vainio, Lich. Bras. Exs. 1289).

Diagnosis--Thallus corticate, smooth to uneven, white-gray. Lirellae sessile, unbranched, lacking thalline margin, jet-black, Melaspilea- 
like, $0.5-2 \mathrm{~mm}$ long, $0.25-0.35 \mathrm{~mm}$ broad; labia entire. Excipulum completely carbonized. Hymenium clear. Ascospores 8 per ascus, transversely 9-17-septate, 50-70 × 13-15 $\mu \mathrm{m}$, hyaline (similar to $G$. elegans type). Secondary chemistry: no substances detected by TLC.

REMARKS-A typical representative of the Graphis nuda group, characterized by its medium-sized, transversely septate ascospores. Graphis ovata has smaller ascospores with terminal gelatinous caps.

SpeCIMENS SEen-COSTA RICA. Alajuela: San Ramón Forest Reserve, near house at Río Lorencito, $5 \mathrm{~km} \mathrm{NE}$ of Cerro Jabonal, $84^{\circ} 37^{\prime} \mathrm{W}, 10^{\circ} 13^{\prime} \mathrm{N}$, $1000 \mathrm{~m}$, humid, mossy forest with many ferns on mountain ridge, on canopy branches of fallen tree, 15 Nov 1988, Sipman et al. 41938 (CR, B). Guanacaste: Volcán Tenorio National Park, Alto Masis Section (Arenal-Tilarán Conservation Area), Tilarán Ridge, $85^{\circ} 00^{\prime} \mathrm{W}, 10^{\circ} 37^{\prime} \mathrm{N}, 950-1000 \mathrm{~m}$, lower montane elfin cloud forest zone, disturbed low elfin forest and secondary vegetation, on bark (lower stem), 17 Mar 2004, Lücking 17323d (F). San José: Los Santos Forest Reserve, Tres de Junio (Pacífico Central Conservation Area), Talamanca Ridge, $83^{\circ} 51^{\prime} \mathrm{W}, 9^{\circ} 39^{\prime} \mathrm{N}, 2750 \mathrm{~m}$, upper montane cloud forest zone, margin of disturbed oak forest, on wood (fence post), 25 Mar 2004, Lücking 17751 (F, INB).

Graphis altamirensis Sipman \& Lücking, sp. nov. Figure 24G.

Sicut Graphis cinerea sed ascosporis submuriformibus angustioribusque differt. Holotype. Costa Rica: Puntarenas: La Amistad International Park, Altamira Station (La Amistad Pacífico Conservation Area), Talamanca Ridge, $83^{\circ} 00^{\prime} \mathrm{W}$, $9^{\circ} 02^{\prime} \mathrm{N}, 1500-1600 \mathrm{~m}$, montane rain forest zone, disturbed primary forest and secondary vegetation dominated by Cecropia, on bark (lower trunk), 30 Jun 2002, Sipman 48019a (INB3927543, holotype).

Paratypes. COSTA RICA. Alajuela: Volcán Tenorio National Park, Pilón Biological Station (ArenalTempisque Conservation Area), Tilarán Ridge, $84^{\circ} 59^{\prime} \mathrm{W}, 10^{\circ} 43^{\prime} \mathrm{N}, 700 \mathrm{~m}$, lower montane cloud forest zone, grazed, abandoned Syzygium jambos plantation surrounded by Gmelina arborea trees and pasture fields, 15 Mar 2004, Sipman 51875 (B, INB-4055179). Guanacaste: Volcán Tenorio National Park, Alto Masis Section (Arenal-Tilarán Conservation Area), Tilarán Ridge, $85^{\circ} 00^{\prime} \mathrm{W}$, $10^{\circ} 36^{\prime} \mathrm{N}, 850-900 \mathrm{~m}$, lower montane moist forest zone, exposed trees and fence posts and forest regrowth along savanna-like pasture, on bark (lower trunk), 17 Mar 2004, Lücking 17307h (F). San José: Along road from San Jerónimo to Alto La Palma, N of San José, $84^{\circ} 01^{\prime} \mathrm{W}, 10^{\circ} 00^{\prime} \mathrm{N}$, $1500 \mathrm{~m}$, on fence poles and scattered trees among pasture fields and gardens, 8 Nov 1988, Sipman et al. 41552 (B, CR). Perez Zeledón, Cordillera de Talamanca, Cerro de la Muerte, $83^{\circ} 46^{\prime} \mathrm{W}$, $9^{\circ} 31^{\prime} \mathrm{N}, 3000 \mathrm{~m}$, Escalonia vegetation, $21 \mathrm{Feb}$ 1996, Inberg 1240a (B, INB).

DESCRIPTION-Thallus corticolous, $2-5 \mathrm{~cm}$ diam., $50-150 \mu \mathrm{m}$ thick, continuous; surface uneven to weakly verrucose, pale greenish gray to white; prothallus absent. Thallus in section with cartilaginous upper cortex, irregular algal layer, and clusters of crystals. Apothecia lirelliform, flexuose, branched, prominent, with thin complete thalline margin, $1-8 \mathrm{~mm}$ long, 0.4 $0.6 \mathrm{~mm}$ wide, $0.3-0.5 \mathrm{~mm}$ high; disc concealed; proper margin very thick, labia striate, dark gray to grayish black with white lines; thalline margin laterally thick, pale gray to white, apically thin (cortex), gray. Excipulum crenulate, completely carbonized, 120-170 $\mu \mathrm{m}$ wide, black; laterally covered by corticate algiferous thallus including clusters of crystals in basal parts; hypothecium prosoplectenchymatous, 15-25 $\mu \mathrm{m}$ high, colorless; hymenium 150-250 $\mu \mathrm{m}$ high, colorless, strongly inspersed (paraphyses and asci hardly visible), inspersion rapidly disappearing in $\mathrm{KOH}$ (type B); epithecium granulose, 5-15 $\mu \mathrm{m}$ high, olive brown. Asci fusiform, 150-220 $\times 25$ $35 \mu \mathrm{m}$. Ascospores 4-6 per ascus, oblong to cylindrical, submuriform with 21-29 transverse and $0-1$ longitudinal septa per segment (sometimes only at one end), $120-180 \times 10-15 \mu \mathrm{m}, 10$ 14 times as long as wide, colorless. Secondary chemistry: no substances detected by TLC.

REMARKS - Graphis altamirensis belongs in the $G$. cinerea aggregate within the $G$. acharii group (Staiger, 2002). The latter is characterized by prominent, robust lirellae covered with a thalline layer, usually striate labia, and completely carbonized excipulum. The $G$. cinerea aggregate includes several, in part newly described species with strongly inspersed hymenium, which vary in ascospore size and septation. Graphis altamirensis is the only species within this aggregate with truly submuriform ascospores; that is, part of the cells along the ascospores have a longitudinal septum. Most closely related is G. subflexibilis, which has slightly shorter, terminally muriform ascospores (i.e., only the terminal cells have longitudinal septa). Other related species include G. pseudocinerea (ascospores muriform, 50-70 $\mu \mathrm{m}$ long), G. phaeospora (ascospores muriform, 25-35 $\mu \mathrm{m}$ broad), and $G$. argentata (ascospores muriform, $80-140 \times 12-20 \mu \mathrm{m})$.

ECOLOGY-Like the other species of this aggregate, Graphis altamirensis seems to be 
restricted to partly exposed microsites in montane rain forests with high amount of precipitation.

\section{Graphis anfractuosa (Eschw.) Eschw. Fig- ure $14 \mathrm{~A}-\mathrm{B}$.}

Graphis anfractuosa (Eschw.) Eschw. in Martius, Fl. Bras. 1(1): 86. 1833; Scaphis anfractuosa Eschw., Syst. Lich.: 25. 1824. Lectotype (fide Nakanishi, annotation label in 1973; Wirth \& Hale, 1978). Brazil, Martius s.n. (M, not seen; G!, isolectotype).

DiAgNosis - Thallus corticate, smooth to uneven, white-gray. Lirellae prominent, partly branched, lacking thalline margin, jet-black, Melaspilea-like, 1-3 mm long, $0.1-0.2 \mathrm{~mm}$ broad; labia entire. Excipulum completely carbonized. Hymenium inspersed (type A). Ascospores 8 per ascus, transversely 7-11-septate, 25$45 \times 6-9 \mu \mathrm{m}$, hyaline. Secondary chemistry: no substances detected by TLC.

REMARKS-The morphology of the lirellae places this species in the Graphis nuda group, within which it can be easily distinguished by its insperse hymenium and relatively small, transversely septate ascospores. Most similar is Graphis virescens, which differs chiefly by the clear hymenium. Staiger (2002) indicates the specimen in $\mathrm{M}$ as holotype, whereas Nakanishi in 1973 on an annotation label states the material in $\mathrm{G}$ to represent the isolectotype of the lectotype in $\mathrm{M}$. We have not seen the material in $\mathrm{M}$, but both Wirth and Hale (1978) and Archer (2006) indicate it as lectotype as well.

Also reported from Costa Rica by Breuss (2004).

Specimens SeEn-COSTA RICA. Cartago: Tres de Junio, $15 \mathrm{~km} \mathrm{~S}$ of El Empalme on road to San Isidro del General, $83^{\circ} 53^{\prime} \mathrm{W}, 9^{\circ} 40^{\prime} \mathrm{N}, 2600 \mathrm{~m}$, grazed forest relics on mountain ridge, 11 Nov 1988, Sipman et al. 41836 (B, CR). Guanacaste: Volcán Tenorio National Park, Alto Masis Section (Arenal-Tilarán Conservation Area), Tilarán Ridge, $85^{\circ} 00^{\prime} \mathrm{W}, 10^{\circ} 37^{\prime} \mathrm{N}, 950-$ $1000 \mathrm{~m}$, lower montane elfin cloud forest zone, disturbed low elfin forest and secondary vegetation, on bark (twig), 17 Mar 2004, Lücking 17345 (F, USJ). Limón: Braulio Carrillo National Park, Quebrada Gonzales Section (Cordillera Volcánica Central Conservation Area), Volcánica Central Ridge, 8356'W, $10^{\circ} 10^{\prime} \mathrm{N}, 500 \mathrm{~m}$, lower montane rain forest zone, primary forest, on bark (lower trunk), 30 Mar 2003, Grube 11216 (GZU). Puntarenas: La Amistad International Park, Altamira Station (La Amistad Pacífico Conservation Area), Talamanca Ridge, $83^{\circ} 00^{\prime} \mathrm{W}$, $9^{\circ} 02^{\prime} \mathrm{N}, 1600-1800 \mathrm{~m}$, montane rain forest zone, secondary forest dominated by Cecropia, on bark (lower trunk), 1 Jul 2002, Sipman 48043j (B). Las Cruces Biological Station and Wilson Botanical
Garden near San Vito, 900-1000 m, montane rain forest zone, planted vegetation and disturbed forest, 10-24 Oct 2004, Sipman 53407 (B, INB); 16 Oct 2004 Bárcenas Peña $126 b$ (INB), Pérez Pérez CR-2020 (INB). San José: Vicinity of Santa Maria de Dota, 1500 $1800 \mathrm{~m}, 26$ Dec 1925 to 3 Jan 1926, Standley \& Valerio 44128. (FH).

\section{Graphis angustata Eschw. Figure 15G.}

Graphis angustata Esch. in Martius, Fl. Bras. 1(1): 73. 1833. Brazil, Martius s.n. (M, not seen).

?Graphis subcurva Zenk. in Goebel \& Kunze, Pharmazeut. Waarenkunde 1: 141 (1829). Type. Unknown locality (not seen).

Graphis flexibilis Kremp., Flora 59: 414. 1876. Lectotype (fide Wirth \& Hale, 1978: 13). Brazil, Glaziou 5106 (M, not seen).

Graphis subanglustata Vain., Ann. Acad. Sci. Fenn., Ser. A, 15(6): 243. 1921. Lectotype (here selected) Philippines, Elmer 14443 (TUR-Vainio 27866!).

Diagnosis--Thallus corticate, smooth to uneven, white-gray. Lirellae prominent, partly branched, with thin complete thalline margin, $1-$ $4 \mathrm{~mm}$ long, $0.4-0.8 \mathrm{~mm}$ broad; labia striate. Excipulum completely carbonized. Hymenium clear. Ascospores $6-8$ per ascus, transversely 15 21 -septate, $90-120 \times 12-15 \mu \mathrm{m}$, hyaline. Secondary chemistry: no substances detected by TLC.

REMARKS-This species is usually characterized by its robust, usually rather short and broad lirellae and internally by its long, transversely septate ascospores (similar to those of Graphis rhizocola). The type material of the synonyms listed here varies in this respect, ranging from short and broad (G. flexibilis) to rather long and narrow lirellae ( $G$. angustata). We have not been able to assess whether these differences have any taxonomic value, but experience with most species suggests that lirellae morphology is usually less variable (see below G. librata). Thus, while Staiger (2002) used the name G. flexibilis for this taxon, we adopt the older name $G$. angustata. Possibly the oldest name is $G$. subcurva Zenk., according to the description given by Müller Argoviensis (1887), but we have not been able to examine type material of this taxon. Graphis vestita Fr. is very closely related to $G$. angustata but, according to Müller Argoviensis (1887), has larger ascospores (120$160 \times 15-25 \mu \mathrm{m})$.

Previously reported from the country by Breuss (2000).

SPECIMENS SEEN-COSTA RICA. Alajuela: Volcán Tenorio National Park, Pilón Biological Station (Arenal-Tempisque Conservation Area), Tilarán Ridge, $84^{\circ} 59^{\prime} \mathrm{W}, 10^{\circ} 43^{\prime} \mathrm{N}, 700 \mathrm{~m}$, lower montane 
cloud forest zone, exposed trees and fence posts along pasture, on wood (fence post), 16 Mar 2004, Lücking 17250 c (CR, F, INB, USJ). Heredia: La Selva Protection Zone, La Selva Biological Station (Cordillera Volcánica Central Conservation Area), Volcánica Central Ridge, $84^{\circ} 03^{\prime} \mathrm{W}, 10^{\circ} 26^{\prime} \mathrm{N}, 50 \mathrm{~m}$, lowland rain forest zone, trees along main road, on bark (lower trunk), 15 Jun 2002, Lücking $15030 b$ (F, INB). Puntarenas: Las Tablas, foot of Cerro Quijada del Diablo (La Amistad Pacífico Conservation Area), 1600-1700 m, 8 $53^{\prime} \mathrm{N}$, $82^{\circ} 45^{\prime} \mathrm{W}, 14$ Jun 2003, Navarro 6591 (INB).

\section{Graphis antillarum Vain. Figure 20E-F.}

Graphis antillarum Vain., Hedwigia 38: 255. 1899; Graphina antillarum (Vain.) Zahlbr., Cat. Lich. Univ. 2: 398. 1923. Holotype. Guadeloupe, Duss 540 (TUR-Vainio 27182!, FH, isotype!).

Graphis platycarpoides Vain., Ann. Acad. Sci. Fenn., Ser. A, 6: 147. 1915. Holotype. Guadeloupe, Duss 1198 (TUR-Vainio 27178!).

DiAGNOSIS-Thallus corticate, smooth to uneven, yellowish gray. Lirellae erumpent, partly branched, with lateral thalline margin, 3-10 mm long, 0.15-0.25 mm broad; labia striate. Excipulum apically (to peripherally) carbonized. Hymenium clear. Ascospores 2-8 per ascus, muriform, 30-60 × 15-25 $\mu \mathrm{m}$, hyaline. Secondary chemistry: norstictic and connorstictic acids.

REMARKS-Most similar are Graphis parilis (stictic acid) and $G$. perstriatula (ascospores smaller). Graphis bipartita differs by its much larger ascospores, among other details. A syntype of G. sophistica (H-Nyl 7394) from Sri Lanka also represents $G$. antillarum.

Reported from Costa Rica by Breuss (2001); not found by us in the present collections.

\section{Graphis aquilonia (A. W. Archer) Staiger. Fig-} ure $17 \mathrm{H}$.

Graphis aquilonia (A. W. Archer) Staiger, Bibl. Lichenol. 85: 209. 2002; Graphina aquilonia A. W. Archer, Mycotaxon 77: 160. 2001. Holotype. Australia, Streimann 56768 (CANB!).

DiAGNOSIS-Thallus corticate, smooth to uneven, white-gray. Lirellae prominent, partly branched, with complete thalline margin, 1$7 \mathrm{~mm}$ long, $0.5-0.7 \mathrm{~mm}$ broad; labia striate. Excipulum completely carbonized. Hymenium clear. Ascospores 2-6 per ascus, terminally muriform with 15-21 transverse septa and 1-2 longitudinal septa in the terminal segments, 100 $170 \times 20-30 \mu \mathrm{m}$, hyaline. Secondary chemistry: norstictic acid.

REMARKS-Graphis aquilonia is somewhat intermediate between G. rhizocola and G. vestitoides. The typically striate lirellae develop relatively late, and the terminal longitudinal septa in the ascospores are easily overlooked. Even the spot test for norstictic acid can be misleading since in one collection the thallus was $\mathrm{K}$-negative, but TLC revealed presence of norstictic acid. The specimens cited below have lirellae with an apically thin thalline cover; hence, the upper part of the labia appears dark gray as in $G$. acharii and $G$. vestitoides. In the Australian material, the lirellae have a thick white thalline cover, resembling a species of Hemithecium rather than Graphis (Archer 2006). The neotropical material might represent a separate taxon, but because of the few specimens available, we have adopted the name $G$. aquilonia for these collections.

Specimens SeEn-COSTA RICA. Heredia: La Selva Protection Zone, La Selva Biological Station (Cordillera Volcánica Central Conservation Area), 50$100 \mathrm{~m}, 10^{\circ} 25^{\prime} \mathrm{N}, 84^{\circ} 00^{\prime} \mathrm{W}$, Mar 2004, Lücking $17076 a$ (F, INB). Limón: Gandoca-Manzanillo Wildlife Refuge, Manzanillo Section (La Amistad Caribe Conservation Area), Manzanillo, $82^{\circ} 53^{\prime} \mathrm{W}, 9^{\circ} 38^{\prime} \mathrm{N}$, sea level, lowland coastal moist forest zone, disturbed coastal vegetation with Cocos nucifera, Coccoloba uvifera, on bark (lower stem), 11 Mar 2004, Lücking 17098 a (F, USJ).

Graphis argentata Lücking \& Umaña, sp. nov. Figure 24B-F.

Sicut Graphis phaeospora sed ascosporis angustioribus differt. Holotype. COSTA RICA. Puntarenas: La Amistad International Park, Altamira Station (La Amistad Pacífico Conservation Area), Talamanca Ridge, $83^{\circ} 00^{\prime} \mathrm{W}, 9^{\circ} 02^{\prime} \mathrm{N}, 1600$ $1800 \mathrm{~m}$, montane rain forest zone, secondary forest and open secondary vegetation dominated by Cecropia, on bark (branch, fallen), 1 Jul 2002, Lücking 15269d (INB-3976268, holotype).

Paratypes. COSTA RICA. Alajuela: La Palma de San Ramón, 1100 m, 8 Oct 1929, Brenes 47 (FH). Volcán Tenorio National Park, Pilón Biological Station (Arenal-Tempisque Conservation Area), Tilarán Ridge, $84^{\circ} 59^{\prime} \mathrm{W}, 10^{\circ} 43^{\prime} \mathrm{N}, 700 \mathrm{~m}$, lower montane cloud forest zone, exposed trees and fence posts along pasture, on wood (fence post), 16 Mar 2004, Lücking 17250ea (F), 17250eb (F), $17250 m$ (F). Guanacaste: Monte Alto Forest Reserve, Cerro Romo (Tempisque Conservation Area), Nicoya Peninsula, $85^{\circ} 24^{\prime} \mathrm{W}, 10^{\circ} 00^{\prime} \mathrm{N}, 750$ $900 \mathrm{~m}$, lowland to lower montane moist forest zone, forest regrowth along pasture, on bark (lower trunk), 22 Mar 2004, Sipman 52066 (B, INB). Volcán Tenorio National Park, Alto Masis Section (Arenal-Tilarán Conservation Area), Tilarán Ridge, $85^{\circ} 00^{\prime} \mathrm{W}, 10^{\circ} 36^{\prime} \mathrm{N}, 850-900 \mathrm{~m}$, lower montane moist forest zone, exposed trees and fence posts and forest regrowth along savanna-like pasture, on bark (lower trunk), 17 Mar 2004, Lïcking 17303d (F), $17304 c$ (F, INB- 
4004932); on bark (twig), 17 Mar 2004, Lücking $17340 a$ (F). Puntarenas: Las Cruces Biological Station and Wilson Botanical Garden near San Vito, 900-1000 m, montane rain forest zone, planted vegetation and disturbed forest, Feb 2000, Lücking 00-8 (F); 10-24 Oct 2004, Lücking $18038 b$ (F), Sipman 53284 (B, INB-3993691). San José: Los Santos Forest Reserve, Cerro de la Muerte Biological Station (Pacífico Central Conservation Area), Talamanca Ridge, $83^{\circ} 45^{\prime} \mathrm{W}$, $9^{\circ} 34^{\prime} \mathrm{N}, 3100-3400 \mathrm{~m}$, upper montane cloud forest zone, partly disturbed subparamo shrub and low forest, on bark (lower stem), 3 Jul 2002, Lïcking 15361 (CR).

Graphis cinereoides Lücking \& Chaves [nom. inval., ICBN Art. 32, 35-37]

DESCRIPTION-Thallus corticolous, $2-5 \mathrm{~cm}$ diam., 50-100 $\mu \mathrm{m}$ thick, continuous; surface uneven, pale greenish gray; prothallus absent. Thallus in section with thick cartilaginous upper cortex, irregular algal layer and clusters of crystals. Apothecia lirelliform, flexuose, partly branched, prominent, with thin complete thalline margin, 1-7 $\mathrm{mm}$ long, $0.3-0.6 \mathrm{~mm}$ wide, 0.25 $0.35 \mathrm{~mm}$ high; disc concealed; proper margin very thick, labia entire (in first-generation lirellae) to striate, grayish black; thalline margin laterally thick, pale gray (in first-generation lirellae with irregular inner edges), apically thin (cortex), gray. Excipulum entire (in first generation of lirellae) to crenulate, completely carbonized, 80-200 $\mu \mathrm{m}$ wide, black, basal internal parts brown; laterally covered by corticate algiferous thallus including clusters of crystals; hypothecium prosoplectenchymatous, 10-20 $\mu \mathrm{m}$ high, colorless to pale yellowish; hymenium 150 $220 \mu \mathrm{m}$ high, colorless, strongly inspersed (paraphyses and asci hardly visible), inspersion rapidly disappearing in $\mathrm{KOH}$ (type $\mathrm{B}$ ); epithecium granulose, $10-20 \mu \mathrm{m}$ high, olive brown. Paraphyses unbranched; asci fusiform, 140-200 $\times 30-50 \mu \mathrm{m}$. Ascospores 4-8 per ascus, oblong, muriform, $80-140 \times 12-20 \mu \mathrm{m}, 5-7$ times as long as wide, colorless. Secondary chemistry: no substances detected by TLC.

REMARKS-Graphis argentata is one example showing that the distinction of striate versus nonstriate forms does not necessarily denote separate taxa. At first, we recognized two different species: one with entire (G. argentata) and one with striate labia ( $G$. cinereoides; the latter name having been used in our Internet keys (http://www.fieldmuseum.org/ticolichen/keys_ graphis.html). However, the two are identical in all other characters, and in one collection (Lücking 17250e), we found a thallus where the entire labia can clearly be recognized as the first generation of the striate form. A similar behavior is known from the common G. chrysocarpa and was also detected in the newly described $G$. subflexibilis, which differs from $G$. argentata by its terminally muriform ascospores. Several other cases can be made, such as G. bulacana versus $G$. glaucescens (see below), although in most instances, taxa with entire or striate labia do not have a corresponding "labiomorph." We also assume here that G. subcinerea Staiger ad interim (Staiger, 2002), with striate labia, is identical with $G$. phaeospora Vain., with entire labia; both have otherwise exactly the same lirellae morphology, hymenium inspersion, and broad, muriform ascospores. However, G. subserpens Staiger ad interim, which closely resembles $G$. cinerea except for the entire versus striate labia, is not a "labiomorph" of the latter since its ascospores are distinctly shorter; hence, the species are well separated. Most closely related to Graplis argentata are G. bettinae (ascospores transversely septate), G. subflexibilis (ascospores terminally muriform), G. altamirensis (ascospores submuriform, $120-180 \times 10-15 \mu \mathrm{m}), G$. pseudocinerea (ascospores 50-70 $\mu \mathrm{m}$ long), and G. phaeospora (ascospores $25-35 \mu \mathrm{m}$ broad).

A specimen of Graphis argentata at $\mathrm{FH}$ was identified as G. tumidulella Fink by Dodge.

ECOLOGY - A chiefly montane species, being also widespread in the Caribbean (Lücking et al., 2008b).

Graphis bettinae Lücking, Umaña, Chaves \& Sipman, sp. nov. Figure 16A-B.

Sicut Graphis argentata sed ascosporis transversaliter septatis differt. Holotype. COSTA RICA. Cartago: Tapantí National Park, Macizo de la Muerte Section, Tres de Junio (La Amistad Pacífico Conservation Area), Talamanca Ridge, $83^{\circ} 51^{\prime} \mathrm{W}, 9^{\circ} 40^{\prime} \mathrm{N}, 2700 \mathrm{~m}$, upper montane rain forest zone, disturbed upland peat bog with scattered shrubs and Blechnum, on bark (twig), 5 Jul 2002, Lücking 15449a (INB-3979520, holotype).

Paratypes. COSTA RICA. San José: Los Santos Forest Reserve, Tres de Junio (Pacífico Central Conservation Area), Talamanca Ridge, $83^{\circ} 51^{\prime} \mathrm{W}$, $9^{\circ} 40^{\prime} \mathrm{N}, 2700 \mathrm{~m}$, upper montane cloud forest zone, margin of disturbed oak forest, on bark (branch), 25 Mar 2004, Lücking 17734 (CR, F, INB-4006023, USJ).

DESCRIPTION-Thallus corticolous, $1-3 \mathrm{~cm}$ diam., $30-80 \mu \mathrm{m}$ thick, continuous; surface uneven, pale greenish gray; prothallus absent. Thallus in section with thick cartilaginous upper 
cortex, irregular algal layer and clusters of crystals. Apothecia lirelliform, flexuose, rarely branched, prominent, with thin complete thalline margin, $1-3 \mathrm{~mm}$ long, $0.2-0.3 \mathrm{~mm}$ wide, 0.2 $0.3 \mathrm{~mm}$ high; disc concealed; proper margin thick, labia entire (probably first-generation lirellae; but see comments below), dark gray to grayish black; thalline margin laterally thick, pale gray (in first-generation lirellae with irregular inner edges), apically thin (cortex), gray. Excipulum entire, completely carbonized, 40$100 \mu \mathrm{m}$ wide, black, basal internal parts brown; laterally covered by corticate algiferous thallus including clusters of crystals; hypothecium prosoplectenchymatous, $10-20 \mu \mathrm{m}$ high, colorless to pale yellowish; hymenium 150-200 $\mu \mathrm{m}$ high, colorless, strongly inspersed (paraphyses and asci hardly visible), inspersion rapidly disappearing in $\mathrm{KOH}$ (type B); epithecium granulose, 5$15 \mu \mathrm{m}$ high, olive brown. Paraphyses unbranched; asci fusiform, 140-180 × 30-40 $\mu \mathrm{m}$. Ascospores 4-8 per ascus, oblong, transversely 15-25-septate, $90-110 \times 11-15 \mu \mathrm{m}, 7-9$ times as long as wide, colorless. Secondary chemistry: no substances detected by TLC.

ETYMOLOGY - We dedicate this new species to Bettina Staiger, who, with her outstanding thesis (Staiger, 2002), has laid the foundation for a very much needed reassessment of the taxonomy of the family Graphidaceae.

REMARKS-Graphis bettinae is another new species in the $G$. cinerea aggregate, that is, with inspersed hymenium. It resembles $G$. subserpens Staiger ad interim (Staiger, 2002), but that taxon has much broader ascospores $(20-30 \mu \mathrm{m})$. Both are here considered to belong to the $G$. cinerea aggregate in the $G$. acharii group, although their lirellae are entire and $G$. subserpens was given as a member of the $G$. carassensis group $(=G$. rhizocola group here) by Staiger (2002). The examples of the newly described $G$. argentata and G. subflexibilis indicate that in this aggregate, thalli with entire labia possibly represent the first-generation lirellae of usually striate species, although striate labia have so far not been found in $G$. bettinae or G. subserpens. Graphis bettinae otherwise resembles $G$. rhizocola, which has similar ascospores and entire labia with completely carbonized excipulum but a noninspersed hymenium and a usually green thallus and slightly different morphology of the thalline margin of the lirellae.

ECOLOGY-Apparently restricted to the upper montane rain and cloud forest zone.
Graphis bipartita (Müll. Arg.) Lücking, comb. nov. Figure $20 \mathrm{G}-\mathrm{H}$.

Graphina bipartita Müll. Arg., Rev. Mycol 10: 19. 1888. Lectotype (fide Wirth \& Hale, 1963: 74). Paraguay, Balansa 1878 (G!).

Graphis peralbida Nyl., Lich. Trop. Labuan et Singapore: 42. 1891; Graphina peralbida (Nyl.) Zahlbr., Cat. Lich. Univ. 2: 418. 1923. Holotype. Mexico, Pringle 222 (H!; $\mathrm{FH}$, isotype!).

DiAgNosis-Thallus corticate, smooth to uneven, yellowish gray. Lirellae erumpent, rarely branched, with complete thalline cover, 3-6 mm long, $0.2-0.4 \mathrm{~mm}$ broad; labia striate. Excipulum apically carbonized. Hymenium clear. Ascospores single, muriform, $60-100 \times 25-40 \mu \mathrm{m}$, hyaline. Secondary chemistry: norstictic acid.

REMARKS - The present material fits the type in most characters (immersed-erumpent lirellae, striate labia, apically carbonized excipulum, clear hymenium, large muriform ascospores, norstictic acid), except that the labia have a lateral instead of complete thalline margin. The identification is therefore preliminary. The taxon that otherwise comes closest to this material is Graphis antillarum, but that species has much smaller ascospores. The type material of $G$. peralbida agrees well with that of G. bipartita.

SPECIMENS SEEN-COSTA RICA. Guanacaste: Monte Alto Forest Reserve, Cerro Romo (Tempisque Conservation Area), Nicoya Peninsula, $85^{\circ} 24^{\prime} \mathrm{W}$, $10^{\circ} 00^{\prime} \mathrm{N}, 750-900 \mathrm{~m}$, lowland to lower montane moist forest zone, forest regrowth along pasture, on bark (lower stem), 22 Mar 2004, Lücking 17579 (F, INB4017492).

\section{Graphis caesiella Vain. Figure 10E.}

Graphis caesiella Vain., Acta Soc. Fauna Fl. Fenn. 7: 122. 1890. Holotype. Brazil, Vainio s.n. (TURVainio 27730!; Vainio, Lich. Brasil Exs. 45).

DiAgNosis - Thallus corticate, smooth to uneven, yellowish gray. Lirellae immersed-erumpent, partly branched, with lateral thalline margin, 1-3 mm long, 0.1-0.2 mm broad; labia entire, white pruinose. Excipulum laterally carbonized. Hymenium clear. Ascospores 8 per ascus, transversely 5-9-septate, $20-40 \times 6-8 \mu \mathrm{m}$, hyaline. Secondary chemistry: norstictic acid.

REMARKS-This species is well characterized by its immersed-erumpent lirellae; entire, white pruinose labia; laterally carbonized excipulum; clear hymenium; small transversely septate ascospores; and norstictic acid. Wirth and Hale (1963) and Harris $(1990,1995)$ mention several, presumedly unnamed "chemomorphs" of Gra- 
phis caesiella, but, as a matter of fact, all have names available. The stictic acid chemomorph is $G$. dendrogramma (with several synonyms), while the salazinic acid chemomorph is identical with G. bakeri Vain. The protocetraric chemomorph reported by Harris (1995) might be G. supracola A. W. Archer. Unless proven otherwise, we assume here that these chemomorphs represent distinct species.

Graphis kakaduensis A. W. Archer (2001d) is identical with $G$. caesiella, except that its lirellae are erumpent rather than immersed and have a smooth thalline cover rather than a pruina. Specimens that partly fit G. kakaduensis but also intergrade with typical $G$. caesiella have been found in the present material, and since Archer (2001d) does not compare its new taxon with $G$. caesiella, we cannot exclude that both are conspecific. In material from Brazil, on the other hand, the two morphs are relatively well separated.

A specimen from Costa Rica housed in FH was identified by Dodge as Graphina innata Redinger. We have not seen original material of that taxon, but the FH specimen is a typical Graphis caesiella.

Specimens SeEn-COSTA RICA. Guanacaste: Monte Alto Forest Reserve, Monte Alto Biological Station (Tempisque Conservation Area), Nicoya Peninsula, $85^{\circ} 24^{\prime} \mathrm{W}, 10^{\circ} 02^{\prime} \mathrm{N}, 450-550 \mathrm{~m}$, lowland to lower montane moist forest zone, disturbed primary and old-growth secondary forest, on bark (lower trunk), 21 Mar 2004, Aptroot 60727 (ABL, INB), Sipman 51988 (B, INB). Limón: Hitoy Cerere Biological Reserve, Hitoy Cerere Biological Station (La Amistad Caribe Conservation Area), Talamanca Ridge, $83^{\circ} 02^{\prime} \mathrm{W}, 9^{\circ} 40^{\prime} \mathrm{N}, 100-150 \mathrm{~m}$, lowland to lower montane rain forest zone, exposed trees and fence posts along pasture, on wood (fence post), 10 Mar 2004, Sipman 51669 (B, INB). Puntarenas: Floodplain and seashore at mouth of Rio Agujas, Peninsula of Osa, 1-5 m, 26 Aug 1936, Dodge \& Goerger 10216 (FH). Las Cruces Biological Station and Wilson Botanical Garden near San Vito, 900-1000 m, montane rain forest zone, planted vegetation and disturbed forest, 10-24 Oct 2004, Sipman 53406 (B, INB).

\section{Graphis caesiocarpa Redinger. Figure 14E-F.}

Graphis caesiocarpa Redinger, Ark. Bot. 27A(3): 23. 1935. Lectotype (here selected). Brazil, Malme 3602 (s 6507!). Syntype. Brazil, Malme 3610 (s 6506!).

DiAgNOSIS-Thallus corticate, smooth to uneven, yellowish gray. Lirellae erumpent, richly branched, with complete thalline cover, 1-3 mm long, $0.1-0.2 \mathrm{~mm}$ broad; labia entire, white pruinose. Excipulum completely carbonized. Hymenium clear. Ascospores 8 per ascus, trans- versely 7-11-septate, $30-40 \times 7-9 \mu \mathrm{m}$, hyaline. Secondary chemistry: norstictic acid.

REMARKS-This taxon is close to Graphis caesiella and G. kakaduensis A. W. Archer and differs chiefly in its completely carbonized excipulum. The two syntypes in S are identical, and the specimen annotated by Archer in 1999 is here selected as lectotype. The Costa Rican material agrees with the type in lirellae anatomy, ascospores, and chemistry, but the thallus cortex is only weakly developed, and the lirellae lack the thin white pruina characteristic of the type material.

SPECIMENS SeEN-COSTA RICA. Cartago: Genesis II Cloud Forest Reserve (La Amistad Pacífico Conservation Area), Talamanca Ridge, 2200-2500 m, montane rain forest to upper montane cloud forest zone, Feb 1997, Lücking 97-66 (F).

\section{Graphis carassensis Vain. Figure 23B.}

Graphis carassensis Vain., Acta Soc. Fauna Fl. Fenn. 7: 105. 1890. Holotype. Brazil, Vainio s.n. (TURVainio 27171!; Vainio, Lich. Bras. Exs. 1467).

DiAGNOSIS-Thallus corticate, smooth to uneven, white-gray. Lirellae prominent, rarely branched, with complete thalline cover lacking crystals, 1-7 mm long, $0.5-0.8 \mathrm{~mm}$ broad; labia entire. Excipulum completely carbonized. Hymenium clear. Ascospores 1-4 per ascus, muriform, 80-120 × 25-35 $\mu \mathrm{m}$, hyaline. Secondary chemistry: no substances detected by TLC.

REMARKS-The present specimens fit the type and other material from Brazil perfectly, although they grow corticolous instead of saxicolous. Graphis carassensis is characterized by rather large, prominent lirellae that are completely covered by a thallus layer. Contrary to other species in this group, such as $G$. illinata, there are no crystals in the thallus layer covering the lirellae, a fact also illustrated by Staiger (2002: 214) although not recognized as taxonomically relevant.

Specimens Seen-COSTA RICA. Cartago: Tapantí National Park, Tapantí Section, Tapantí Station (La Amistad Pacífico Conservation Area), Talamanca Ridge, $83^{\circ} 48^{\prime} \mathrm{W}, 9^{\circ} 46^{\prime} \mathrm{N}, 1150 \mathrm{~m}$, montane rain forest zone, living fence trees along roadside pasture, on bark (lower stem), 2 Apr 2003, Lücking 16605b (F, INB). Puntarenas: La Amistad International Park, Altamira Station (La Amistad Pacífico Conservation Area), Talamanca Ridge, $83^{\circ} 00^{\prime} \mathrm{W}, 9^{\circ} 02^{\prime} \mathrm{N}, 1600-1800 \mathrm{~m}$, montane rain forest zone, secondary forest and open secondary vegetation dominated by Cecropia, on bark (lower trunk), 1 Jul 2002, Lücking $15273 b$ (F, INB) Cerro Biolley Section, Sabanas Esperanza (La Amistad Pacífico Conservation Area), Terraba Valley, $83^{\circ} 03^{\prime} \mathrm{W}, 9^{\circ} 04^{\prime} \mathrm{N}, \quad 1300-1400 \mathrm{~m}$, lowland to lower 
montane moist forest savanna zone, disturbed savanna vegetation with abundant shrubs and trees, on bark (lower trunk), 2 Jul 2002, Lïcking $15309 b$ (ESS, F).

Graphis caribica Lücking. Figure 8C.

Graphis caribica Lücking in Lücking et al., Fieldiana (in press). Holotype. Dominica, Imshaug \& Imshaug 32777-A2 (MSC-0006670!).

DiAGNOSIS-Thallus corticate, uneven, yellow-green. Lirellae prominent, partly branched, lacking thalline margin, 1-5 $\mathrm{mm}$ long, 0.3$0.4 \mathrm{~mm}$ broad; labia striate. Excipulum apically (to peripherally) carbonized. Hymenium clear. Ascospores 8 per ascus, transversely 9-15-septate, 50-65 × 9-12 $\mu \mathrm{m}$, hyaline. Secondary chemistry: no substances detected by TLC.

REMARKS-This new species was first discovered in material from Costa Rica but subsequently also found in several collections from the Caribbean made by Imshaug and housed in MSC and at least one specimen from Florida. Since most of the Costa Rican collections lack ascospores, the Imshaug collections provided a more appropriate type material (Lücking et al., 2008b). Graphis caribica is a very characteristic species, differing from other representatives of the genus by its yellowish green, uneven-verrucose instead of grayish white thallus. The thallus resembles that of Phaeographis and related taxa, but hymenium and ascospores are Graphis-like. Graphis caribica is morphologically very similar to the newly described G. fournierii; both are externally indistinguishable and even have similar ecological preferences, but the latter has a more or less completely carbonized excipulum and muriform ascospores. Both species also resemble Glyphis substriatula, which was also often found at the same localities, and Graphis fournierii has the same ascospore type as the Glyphis, but the latter can be distinguished by its narrower, much branched lirellae with dark brown pruina along the slit and its Glyphis-type, apically anastomosing paraphyses. Apart from the different thallus morphology, G. caribica is most similar to $G$. rockii, which in addition to its white-gray thallus also differs in having smaller ascospores $(25-50 \times$ $7-10 \mu \mathrm{m}$ versus $50-65 \times 9-12 \mu \mathrm{m})$. The common $G$. proserpens also differs by its white thallus and much smaller ascospores $(20-40 \times 6-9 \mu \mathrm{m})$ in addition to its very long, slender lirellae.

The species was also found among the material collected by Dodge in Costa Rica and housed in FH, identified as Graphis leptocarpa.

Specimens SeEn-COSTA RICA. Alajuela: La Palma de San Ramón, 1100 m, 22 Oct 1929, Brenes
84 (FH). Volcán Tenorio National Park, Pilón Biological Station (Arenal-Tempisque Conservation Area), Tilarán Ridge, $84^{\circ} 59^{\prime} \mathrm{W}, 10^{\circ} 43^{\prime} \mathrm{N}, 700-900 \mathrm{~m}$, lower montane cloud forest zone, partly disturbed primary forest, on bark (branch), 16 Mar 2004, Lücking $17265 a b$ (F). Guanacaste: Barra Honda National Park, Barra Honda Biological Station (Tempisque Conservation Area), Barra Honda Mountains, $85^{\circ} 21^{\prime} \mathrm{W}$, $10^{\circ} 10^{\prime} \mathrm{N}, 400-500 \mathrm{~m}$, lowland to lower montane moist forest zone, disturbed primary and old-growth secondary forest with calcareous rock outcrops, on bark (lower stem), 22 Mar 2004, Lücking 17550 e (F), 17557 a (F). Monte Alto Forest Reserve, Monte Alto Biological Station (Tempisque Conservation Area), Nicoya Peninsula, $85^{\circ} 24^{\prime} \mathrm{W}, 10^{\circ} 02^{\prime} \mathrm{N}, 450-550 \mathrm{~m}$, lowland to lower montane moist forest zone, disturbed primary and old-growth secondary forest, on bark (lower trunk), 21 Mar 2004, Lücking 17511e (F, INB-4017320).

USA. Florida: Manatee, s.dat., Reasoner s.n. (F1204901)

\section{Graphis chlorotica A. Massal. Figure 8D.}

Graphis chlorotica A. Massal. in Kremp., Verh. K. K. Zool.-Bot. Gesellsch. Wien, 21: 865. 1871. Type. Indonesia (Java), s.col. (W, not seen).

Graphis subtenella Müll. Arg., Flora 70: 400. 1887. Holotype. Australia, Sayer s.n. (G!).

Graphis duplicata var. australasiatica Vain., Ann. Acad. Sci. Fenn., Ser. A, 15(6): 245. 1921. Holotype. Philippines, McGregor 8545 (TURVainio 27628!)

DiAGNOSIS - Thallus corticate, smooth to uneven, white-gray. Lirellae erumpent, partly branched, with lateral thalline margin, $1-4 \mathrm{~mm}$ long, 0.1-0.15 mm broad; labia (entire to) striate. Excipulum apically (to peripherally) carbonized. Hymenium clear. Ascospores 8 per ascus, transversely 7-9-septate, 20-35 $\times 5-7 \mu \mathrm{m}$, hyaline. Secondary chemistry: no substances detected by TLC.

REMARKS - This species agrees in most aspects with Graphis proserpens and would be an earlier name if both are considered synonymous. However, the two seem to differ constantly in having immersed-erumpent, relatively robust and sparsely branched lirellae with lateral thalline margin $(G$. chlorotica) versus erumpent to prominent, rather delicate and richly branched lirellae lacking or with basal thalline margin ( $G$. proserpens). For some time we used the name G. subtenella Müll. Arg. for this taxon, considering $G$. chlorotica a separate species, but examination of Hale's note cards revealed that both are conspecific. Graphis subtenella was considered a synonym of $G$. tenella by Archer (2006), supposedly because Müller Argoviensis (1887) had separated them on the basis of striate versus nonstriate lirellae (although striate lirellae are also present in the type of $G$. tenella). 
However, the difference between the two taxa is not striation but the apically (subtenella) versus laterally (tenella) carbonized excipulum (see below).

Specimens SEen-COSTA RICA. Alajuela: Volcán Tenorio National Park, Pilón Biological Station (Arenal-Tempisque Conservation Area), Tilarán Ridge. $84^{\circ} 59^{\prime} \mathrm{W}, 10^{\circ} 43^{\prime} \mathrm{N} .700 \mathrm{~m}$, lower montane cloud forest zone, exposed trees and fence posts along pasture, on bark (lower trunk, living fence), 16 Mar 2004. Lïcking $17251 i$ (F, INB). Same locality, grazed, abandoned Syzyginum jambos plantation surrounded by Gmelina arborea trees and pasture fields, 15 Mar 2004. Sipman 51764 (B. INB). Puntarenas: Las Cruces Biological Station and Wilson Botanical Garden near San Vito, 900-1000 m, montane rain forest zone, planted vegetation and disturbed forest, 10-24 Oct 2004, Lücking 18020 (F), 18043 (F), 18048 (CR), 18051 (USJ).

Graphis chondroplaca (Redinger) Lücking, comb. et stat. nov. Figure $11 \mathrm{G}-\mathrm{H}$.

Graphis lineola var. chondroplaca Redinger, Ark Bot. 27A(3): 46. 1935. Lectotype (here selected!). Brazil. Malme 1167 (s 6495!). Syntypes. Brazil, Malme 220 (s 6494!), Malme 1900 (s 6496!).

Schistostoma dehiscens Stirt., Proc. Roy. Philos. Soc. Glasgow 11: 312. 1879. Holotype. India, Watt s.n. (BM, not seen).

?Graphis guimarana Vain., Ann. Acad. Sci. Fenn. Ser. A, 15(6): 248. 1921. Lectoype (fide Nakanishi. annot. 1973). Philippines, Merrill 6716 (TUR-Vainio 27811!).

DIAGNOSIS-Thallus corticate, smooth to uneven, yellowish gray. Lirellae erumpent, rarely branched, with lateral thalline margin, $1-3 \mathrm{~mm}$ long, $0.1-0.2 \mathrm{~mm}$ broad; labia entire; disc exposed. Excipulum laterally (to thinly completely) carbonized. Hymenium inspersed (type A). Ascospores 8 per ascus, transversely 7-9septate, $30-45 \times 6-9 \mu \mathrm{m}$, hyaline. Secondary chemistry: norstictic acid.

REMARKS-Staiger (2002) used the name Graphis apertella A. W. Archer for this widespread neotropical taxon with erumpent lirellae, lateral thalline margin, entire labia, exposed nonpruinose dark brown disc, laterally carbonized excipulum, inspersed hymenium, small transversely septate ascospores, and norstictic acid. Several other names have been described in this complex of taxa with exposed discs and inspersed hymenia (see Table 6): Schistostoma dehiscens Stirt. (a name that cannot be used in Graphis; disc nonpruinose, norstictic acid), Graphis lineola var. chondroplaca Redinger (disc nonpruinose, norstictic acid), G. crebra Vain. (disc white pruinose, norstictic acid), G. marginata G. Mey. \& Flot., nom. illeg. (here replaced by $G$. sub- marginata Lücking, see below; disc white pruinose, no substances), G. aperiens Müll. Arg. (disc white pruinose, norstictic acid, excipulum completely carbonized), G. semiaperta Müll. Arg. (disc white pruinose, norstictic acid, excipulum completely carbonized), and $G$. chromothecia R. C. Harris (disc orange pruinose, anthraquinones, excipulum completely carbonized). While the latter four are separated by either their chemistry or completely carbonized excipulum, the application of the names $G$. apertella, G. crebra, and $G$. lineola var. chondroplaca remains somewhat unclear since they differ chiefly by absence or presence of a pruina on the disc, a variation that is widely accepted as infraspecific variation in the closely related $G$. scripta (see below). Archer (2001d, 2006) does not mention pruinose discs in his description of $G$. apertella, but in the photograph of the holotype (Archer 2001d: 260), the discs appear pruinose. Hence, we consider it likely for this taxon to represent a synonym of $G$. crebra, whereas for the mostly neotropical populations lacking a pruina, the name $G$. chondroplaca is installed. Archer did study the type material of $G$. lineola var. chondroplaca (as evident from an annotation slip on Malme 220) but did not mention this taxon in the discussion of $G$. apertella. He apparently also was unaware of $G$. crebra, which agrees rather well with the description of $G$. apertella. The three syntypes of Graphis lineola var. chondroplaca all belong to the same taxon, and we selected the most richly developed specimen as lectotype.

SPecimens Seen - COSTA RICA. Cartago: Cerro Carpintera, 1320-1700 m, 1 Nov 1929, Dodge \& Thomas 8314 (FH). San José: Leonel Oviedo Ecological Reserve (Cordillera Volcánica Central Conservation Area), Central Valley, San José, $84^{\circ} 03^{\prime} \mathrm{W}, 9^{\circ} 56^{\prime} \mathrm{N}$, $1200 \mathrm{~m}$, lower montane moist forest zone, old-growth secondary forest, on bark (lower trunk), 22 Apr 2003, Lücking 16276 (F); 4 Nov 2002, Lücking 15668 (F, USJ). Roadsides between Desamparados and Alajuela, 900$1000 \mathrm{~m}, 31$ Oct 1929, Dodge \& Thomas 4775 (FH). Universidad de Costa Rica Campus (Cordillera Volcánica Central Conservation Area), Central Valley, San José, $84^{\circ} 03^{\prime} \mathrm{W}, 9^{\circ} 56^{\prime} \mathrm{N}, 1200 \mathrm{~m}$, lower montane moist forest zone, planted trees on campus, on bark (lower trunk), 20 Jun 2002, Lücking 15049c (F).

Graphis chrysocarpa (Raddi) Spreng. Figure 7A-B.

Graphis chrysocarpa (Raddi) Spreng., Syst. Veg. Lich. 4(1): 253. 1827; Opegrapha chrysocarpa Raddi, Mem. Mat. Fis. Soc. Ital. Sci. 18: 344. 1820; Ctesium croceum Pers. in GaudichaudBeaupré, Bot. Voy. Uranie: 185. 1827 [nom. illeg., ICBN Art. 52.1, 52.2]; Graphina chrysocarpa (Raddi) Müll. Arg., Flora 63: 41. 1880; 
Phaeographina chrysocarpa (Raddi) Redinger, Ark. Bot. 26A(1): 83. 1934. Holotype. Brazil, s.col. (FI, probably lost). Neotype (fide Staiger 2002: 217). Ecuador, Frisch 96/Eq325 (M, not seen).

Graphis ignea Kremp., Flora 44: 131. 1861. Holotype. Panama, Wagner s.n. (M, not seen).

?Graphis kermesina Fée, Bull. Soc. Bot. France 21: 29. 1874. Holotype. Brazil, Glaziou 1895 (G, not seen).

?Graphis rubricosa Fée, Bull. Soc. Bot. France 21: 29. 1874. Syntypes. Brazil, Glaziou 2159, 2173 (G, not seen).

DiAGNOSIS-Thallus corticate, smooth to uneven, white-gray. Lirellae prominent, partly branched, lacking thalline margin, $1-8 \mathrm{~mm}$ long, $0.5-0.8 \mathrm{~mm}$ broad; labia (entire to) striate, orange pruinose, $\mathrm{K}+$ pink-purple. Excipulum completely carbonized. Hymenium clear. Ascospores 2-6 per ascus, muriform, 120-190 × 17$23 \mu \mathrm{m}$, hyaline. Secondary chemistry: anthraquinones.

REMARKS-Because of its bright orange lirellae, Graphis chrysocarpa is one of the most commonly collected species of the genus in the Neotropics. The abundant material available and studied from Costa Rica and the West Indies (Lücking et al., 2008b) allowed for a detailed study of variation in lirellae morphology and ascospore size and septation. First of all, it soon became obvious that $G$. chrysocarpa is one of the species where entire and striate labia occur in the same taxon, often on different thalli but not rarely also mixed on the same thallus. The entire, first-generation lirellae look different from older, strongly striate lirellae, but the material available leaves absolutely no doubt that it deals with the same taxon.

The fact that Graphis chrysocarpa s.lat. has been placed into three different ascospore genera (Graphis, Graphina, Phaeographina) is partly due to ascospore variation. The species in a strict sense has very large $(120-200 \times 15-25 \mu \mathrm{m})$, richly muriform ascospores that sometimes have a pale grayish brown pigmentation and thus fit the previous definition of both Graphina and Phaeographina, respectively. However, there are at least three further taxa previously confused with Graphis chrysocarpa, but with smaller (70$120 \times 10-15 \mu \mathrm{m})$, terminally muriform or transversely septate and always hyaline ascospores: Graphis miniata, G. subchrysocarpa (see below), and Graphis lutea (Chevall.) Aptroot, comb. nov. [Bas. Allographa lutea Chevall., Histoire des Graphidées: XVI, fig. 3d, e. 1824.
Lectotype (here selected). Unknown locality, s.col.. (L!)]. The first two differ from Graphis chrysocarpa s.str. by their smaller, terminally murifom ascospores, and $G$. miniata also deviates by its lirellae, covered by a grayish white thallus cover and with the orange pigment hidden beneath and between the stria and visible only when the thallus cover flakes off. Allographa lutea was neotypified by Staiger (2002) with a specimen belonging to Graphis chrysocarpa s.str. However, an isotype detected by the last author in $\mathrm{L}$ superseeds the neotype; it closely resembles $G$. chrysocarpa but has transversely septate ascospores and an apically carbonized excipulum only. We have not found type material of $G$. kermesina and G. rubricosa, neither in G nor in L, and hence the names listed as synonyms of $G$. chrysocarpa by Staiger (2002) are listed here with question marks. The descriptions given by Fée (1874) are not conclusive as to whether it deals with G. chrysocarpa s.str. or any of the other taxa now distinguished in this aggregate, that is, $G$. lutea, G. miniata, G. subchrysocarpa, or Hemithecium plicosum (see next paragraph).

Graphina malmei Redinger (Staiger 2002) represents a noncarbonized equivalent of Graphis chrysocarpa. Its generic placement was regarded uncertain by Staiger (2002: 452). However, the pale excipulum, together with the olive-green rather than white-gray thallus, suggests placement in Hemithecium s.str. The type material of Opegrapha plicosa Meissn. is conspecific with Graphina malmei and represents an earlier epithet, and we propose the new combination Hemithecium plicosum (Meissn.) Lücking \& Aptroot, comb. nov. [Bas.: Opegrapha plicosa Meissn., Bot. Zeitung 13: 422. 1855. Lectotype (here selected). Surinam, Kegel 1419 (L!); = Graphina malmei Redinger, Ark. Bot. 26A(1): 49. 1933].

Specimens SeEN_COSTA RICA. Alajuela: Arenal National Park (Arenal Conservation Area), 500$600 \mathrm{~m}, 10^{\circ} 28^{\prime} \mathrm{N}, 84^{\circ} 44^{\prime} \mathrm{W}, 9$ Jan 2004 , Chaves 1135 (INB); Tucanes trail, 600-700 m, $10^{\circ} 26^{\prime} \mathrm{N}, 84^{\circ} 43^{\prime} \mathrm{W}$, primary and secondary forest, 10 Jan 2004, Chaves 1150 (INB); Peninsula section (Arenal Conservation Area), $500-600 \mathrm{~m}, 10^{\circ} 27^{\prime} \mathrm{N}, 84^{\circ} 45^{\prime} \mathrm{W}, 11$ Jan 2004 , Chaves 1158 (INB). Bijagua, Zapote, La Tigra (Arenal Conservation Area), 450-550 m, $10^{\circ} 44^{\prime} \mathrm{N}, 85^{\circ} 05^{\prime} \mathrm{W}$, 16 Jan 2005, López 6582 (INB). Colinas de San Pedro de San Ramón, 16 Jan 1934, Brenes 18971 (FH), 18972 (FH). Huetar Norte, Boca Tapada, Refugio Nacional de Vida Silvestre Mixto Maquenque, Río San Carlos, 0-100 m, $10^{\circ} 41^{\prime} \mathrm{N}, 84^{\circ} 11^{\prime} \mathrm{W}, 7$ Apr 2005, Chaves 2349 (INB), 2375 (INB). Miravalles Protection Zone, Altamira Section (Arenal Conservation Area), 600-700 m, $10^{\circ} 44^{\prime} \mathrm{N}, 85^{\circ} 05^{\prime} \mathrm{W}, 8$ Aug 2003, Chaves 1019 (INB), 990 
(INB); Zapote Section (Arenal Conservation Area), $800-900 \mathrm{~m}, 10^{\circ} 44^{\prime} \mathrm{N}, 85^{\circ} 06^{\prime} \mathrm{W}, 15$ Jan 2005, López 6547 (INB), 6550 (INB). Tenorio Protection Zone, Sector Quebradón (Arenal Conservation Area), 500$600 \mathrm{~m}, 10^{\circ} 37^{\prime} \mathrm{N}, 84^{\circ} 54^{\prime} \mathrm{W}, 25$ Jan 2005, Chaves 2060 (INB), López 6656 (INB), 6665 (INB). Volcán Tenorio National Park, El Pilón Section (Arenal Conservation Area), $700-800 \mathrm{~m}, 10^{\circ} 42^{\prime} \mathrm{N}, 84^{\circ} 59^{\prime} \mathrm{W}$, secondary forest, 15 Jul 2004, López 5596 (INB); Pilón Biological Station (Arenal-Tempisque Conservation Area), Tilarán Ridge, $84^{\circ} 59^{\prime} \mathrm{W}, 10^{\circ} 43^{\prime} \mathrm{N}, 700 \mathrm{~m}$, lower montane cloud forest zone, exposed trees and fence posts along pasture, on bark (lower stem), 15 Mar 2004, Lücking 17208 a (CR, USJ); on bark (lower trunk), 15 Mar 2004, Aptroot 60456 (ABL, INB); 16 Mar 2004, Will-Wolf 12765 (CR, F, INB, WIS); on bark (lower trunk, living fence), 16 Mar 2004, Lücking $17251 f$ (F). Cartago: Barbilla National Park (La Amistad Caribe Conservation Area), main trail to Río Danta. 400-500 m, $9^{\circ} 59^{\prime} \mathrm{N}, 83^{\circ} 29^{\prime} \mathrm{W}, 16$ Feb 2003, Chaves 367 (INB). Orosi village (Cordillera Volcánica Central Conservation Area), Orosi Valley, $83^{\circ} 50^{\prime} \mathrm{W}, 9^{\circ} 50^{\prime} \mathrm{N}, 1100 \mathrm{~m}$, montane rain forest zone, planted trees at gas station, on bark (lower trunk), 2 Apr 2003, Grube 11424 (GZU). Santiago, 1140-1180 m, 8 Oct 1929, Dodge 4588 (FH). Tapanti National Park, Tapantí Section, Tapantí Station (La Amistad Pacífico Conservation Area), Talamanca Ridge, $83^{\circ} 47^{\prime} \mathrm{W}, 9^{\circ} 45^{\prime} \mathrm{N}, 1300-1400 \mathrm{~m}$, montane rain forest zone, closed primary forest and roadside, on bark (lower stem), 2 Apr 2003, Will-Wolf $12533 a$ (CR, WIS); $83^{\circ} 48^{\prime} \mathrm{W}, 9^{\circ} 46^{\prime} \mathrm{N}, 1150 \mathrm{~m}$, montane rain forest zone, living fence trees along roadside pasture, on bark (lower stem), 2 Apr 2003, Lücking $16605 a$ (F, INB). Guanacaste: Arenal Lake, near Río Piedras (Arenal Conservation Area), 500-600 m, $10^{\circ} 33^{\prime} \mathrm{N}, 84^{\circ} 58^{\prime} \mathrm{W}, 13 \mathrm{Jul} 2004$, Chaves 1835 (INB). Arenal-Monteverde Protection Zone, San Gerardo Biological Station (Arenal Conservation Area), 1100 $1200 \mathrm{~m}, 10^{\circ} 22^{\prime} \mathrm{N}, 84^{\circ} 48^{\prime} \mathrm{W}, 16$ Jan 2003, Chaves 138 (INB), 172 (INB). Quebrada Azul, Tilarán (Arenal Conservation Area), $700-800 \mathrm{~m}, 10^{\circ} 31^{\prime} \mathrm{N}, 84^{\circ} 59^{\prime} \mathrm{W}$, 1 Mar 2003, Chaves 1207 (INB), 1219 (INB). Heredia: La Selva Protection Zone, La Selva Biological Station (Cordillera Volcánica Central Conservation Area), 0 $100 \mathrm{~m}, 10^{\circ} 25^{\prime} \mathrm{N}, 84^{\circ} 00^{\prime} \mathrm{W}, 17$ Oct 2005 , Chaves 2470 (INB). La Selva Protection Zone, La Selva Biological Station (Cordillera Volcánica Central Conservation Area), Volcánica Central Ridge, $84^{\circ} 03^{\prime} \mathrm{W}, 10^{\circ} 26^{\prime} \mathrm{N}$, $50 \mathrm{~m}$, lowland rain forest zone, trees along main road, on bark (lower stem), 15 Jun 2002, Lücking 15023 b (F), $15025 h$ (F, INB), $15026 k$ (INB); s.dat., Lücking 526 (F); 15 Jun 2002, Lïcking 15024d (F), 15030a (CR, F, INB, USJ). Limón: Finca Castilla, $30 \mathrm{~m}$, forest, 23-29 Jul 1936, Dodge \& Goerger 9384 (FH). Hitoy Cerere Biological Reserve (La Amistad Caribe Conservation Area), El Espavel trail, 200-300 m, $9^{\circ} 40^{\prime} \mathrm{N}, 83^{\circ} 01^{\prime} \mathrm{W}$, 2 Sep 2003, Chaves 1082 (INB). Hitoy Cerere Biological Reserve, Hitoy Cerere Biological Station (La Amistad Caribe Conservation Area), Talamanca Ridge, $83^{\circ} 02^{\prime} \mathrm{W}, 9^{\circ} 40^{\prime} \mathrm{N}, 100-150 \mathrm{~m}$, lowland to lower montane rain forest zone, exposed trees and fence posts along pasture, on bark (lower trunk), 10 Mar 2004, Trest 1511 (INB), $1516 k$ (CR), Lücking $17026 \mathrm{~g}$ (F). Puntarenas: Las Cruces Biological Station and Wilson Botanical Garden near San Vito, 900-1000 m, montane rain forest zone, planted vegetation and disturbed forest, 16-21 Oct 2004, Bates 1012 (ASU). Corcovado National Park, Los Patos Section, Los Patos Station (Osa Conservation Area), Osa Peninsula, $83^{\circ} 29^{\prime} \mathrm{W}$, $8^{\circ} 34^{\prime} \mathrm{N}, 100-300 \mathrm{~m}$, lowland rain forest zone, closed primary forest, on bark (branch, fallen), $6 \mathrm{Apr} 2003$, Trest 1381 a (CR, WIS); on bark (trunk, fallen), 6 Apr 2003, Nelsen 3562 (WIS); Sirena Section, Sirena Biological Station (Osa Conservation Area), Osa Peninsula, $83^{\circ} 35^{\prime} \mathrm{W}, 8^{\circ} 29^{\prime} \mathrm{N}$, sea level, lowland and coastal rain forest zone, old-growth coastal secondary forest and primary forest remnants on sandy soil, on bark (upper trunk), 7 Apr 2003, Will-Wolf 12568a (F, IVIS); lowland coastal rain forest zone, disturbed coastal forest and exposed trees along beach, on bark (lower stem), 7 Apr 2003, Sipman 51135f (B, INB), $51146 b$ (B, CR). La Amistad International Park, Altamira Station (LaAmistad Pacífico Conservation Area), Talamanca Ridge, $83^{\circ} 00^{\prime} \mathrm{W}, 9^{\circ} 02^{\prime} \mathrm{N}, 1450 \mathrm{~m}$, lower montane rain forest zone, planted trees on and adjacent to campground, on bark (lower stem), 30 Jun 2002, Lücking 15239b (INB), Nelsen 2097g (WIS) $83^{\circ} 00^{\prime} \mathrm{W}, 9^{\circ} 02^{\prime} \mathrm{N}, 1500-1600 \mathrm{~m}$, montane rain forest zone, disturbed primary forest and secondary vegetation dominated by Cecropia, on bark (lower trunk), 30 Jun 2002, Nelsen 2078d (WIS). Las Cruces Biological Station and Wilson Botanical Garden near San Vito, 900-1000 m, montane rain forest zone, planted vegetation and disturbed forest, 10-24 Oct 2004, Amtoft 3004 (INB, NY), 3005 (INB, NY), 3006 (INB, NY); 10-24 Oct 2004, Lücking 18002 (F), 18005 (CR), 18012 (USJ), 18054 (F), Sipman 53281 (B, INB), 53358 (B, INB); 16 Oct 2004, Bárcenas Peña 110 (INB), Carballo 26 (INB), Mata García S.n. (INB), Mercado 2 (INB), Moncada 3002 (INB), 3028 (INB), Murillo \& Castillo B-003I (INB), $B-0035$ (Inb, UnA), Pérez Pérez CR-2008 (INB); 16-21 Oct 2004, Bates 1012 (INB), 1026 (ASU, INB); 18 Oct 2004, Paredes et al. 1073 (INB). Las Tablas Protection Zone, Cedro Ridge, Las Alturas Station (La Amistad Pacífico Conservation Area), Talamanca Ridge, $82^{\circ} 50^{\prime} \mathrm{W}, 8^{\circ} 57^{\prime} \mathrm{N}, 1600 \mathrm{~m}$, montane rain forest zone, pasture with group of trees bordering forest, on bark (lower trunk), 26 Jun 2002, Sipman 47819d (B, INB). Potrero Grande savannas (La Amistad Pacífico Conservation Area), Terraba Valley, Clavera, $83^{\circ} 11^{\prime} \mathrm{W}, 8^{\circ} 59^{\prime} \mathrm{N}, 250 \mathrm{~m}$, lowland moist forest savanna zone, disturbed roadside savanna and pasture, on bark (branch), 3 Jul 2002, Nelsen 2162c (INB). San Vito, Las Cruces Biological Station arid Wilson Botanical Garden (La Amistad Pacífico Conservation Area), $1200-1300 \mathrm{~m}, 8^{\circ} 47^{\prime} \mathrm{N}, 82^{\circ} 57^{\prime} \mathrm{W}, 13$ Oct 2004 , Chaves 1963 (INB). San José: San Pedro de Montes de Oca, 4 Oct 1929, Thomas s.n. (FH).

\section{Graphis cinerea Fée. Figure 16C-D.}

Graphis cinerea Fée, Essai Crypt. Écorc.: 31. 1824 Holotype. South America, unknown locality, s.dat., s.col. (G!).

Diagnosis - Thallus corticate, smooth to uneven, white-gray. Lirellae prominent, rarely branched, with thin complete thalline margin, 1-4 mm long, $0.6-1.2 \mathrm{~mm}$ broad; labia striate. Excipulum completely carbonized. Hymenium inspersed (type B). Ascospores 1-4 per ascus, 
transversely 19-29-septate, $120-220 \times 18-$ $30 \mu \mathrm{m}$, hyaline. Secondary chemistry: no substances detected by TLC.

REMARKS-Graphis cinerea forms the center of an aggregate of several species with lirellae similar to those of $G$. acharii but differing in their strongly inspersed hymenium. The inspersion is of a different nature than that found in G. lineola and related species; it is much denser and often makes if difficult to see asci and ascospores even in thin sections (type B inspersion). The species within the $G$. cinerea aggregate differ chiefly by ascospore size and septation, those of $G$. cinerea being very large and broad but only transversely septate.

SPECIMENS SEen-COSTA RICA. Alajuela: Volcán Tenorio National Park, Pilón Biological Station (Arenal-Tempisque Conservation Area), Tilarán Ridge, $84^{\circ} 59^{\prime} \mathrm{W}, 10^{\circ} 43^{\prime} \mathrm{N}, 700 \mathrm{~m}$, lower montane cloud forest zone, exposed trees and fence posts along pasture, on bark (lower trunk), 15 Mar 2004, Lücking 17210 (CR, F, USJ). Puntarenas: La Amistad International Park, Altamira Station (La Amistad Pacífico Conservation Area), Talamanca Ridge, $83^{\circ} 00^{\prime} \mathrm{W}, 9^{\circ} 02^{\prime} \mathrm{N}, 1500$ $1600 \mathrm{~m}$, montane rain forest zone, disturbed primary forest and secondary vegetation dominated by Cecropia, on bark (lower trunk), 30 Jun 2002, Lücking 15222 b (CR, ESS, F, INB, USJ); $83^{\circ} 00^{\prime} \mathrm{W}, 9^{\circ} 02^{\prime} \mathrm{N}, 1600-1800 \mathrm{~m}$, montane rain forest zone, secondary forest and open secondary vegetation dominated by Cecropia, on bark (branch), 1 Jul 2002, Lücking 15247c (F). Mellizas, border to Panama (La Amistad Pacífico Conservation Area), $1400-1500 \mathrm{~m}, 8^{\circ} 53^{\prime} \mathrm{N}, 82^{\circ} 46^{\prime} \mathrm{W}, 28$ Aug 2002 , Navarro $5278 h$ (INB).

\section{Graphis cleistoblephara Nyl. Figure 25G-H.}

Graphis cleistoblephara Nyl. in Triana \& Planchon, Ann. Sci. Nat. Bot., Sér. 4, 20: 265. 1863. Holotype. China (Hong Kong), s.dat., s.col. (HNyl 7589!).

?Opegrapha hiascens Fée, Suppl. Essai Crypt. Écorc.: 25. 1837; Graphina hiascens (Fée) Müll. Arg., Mém. Soc. Phys. Nat. Hist. Genève 29: 42. 1887; Graphis hiascens (Fée) Nyl., Ann. Sci. Nat. Bot., Sér. 4, 11. 226. 1859; Graphina hiascens (Fée) A. W. Archer, Telopea 11: 73. 2005. Holotype. South America, unknown locality, s.col. (G, not seen).

Graphina subpulicaris Zahlbr., Feddes Repert. 31: 212. 1933. Holotype. Taiwan [Formosa], Asahina s.n. (w!).

DiAGNOSIS-Thallus corticate, smooth to uneven, yellowish gray. Lirellae prominent, unbranched, with lateral thalline margin, $0.5-1 \mathrm{~mm}$ long, $0.4-0.5 \mathrm{~mm}$ broad; labia entire. Excipulum completely carbonized. Hymenium clear. Ascospores 2-4 per ascus, muriform, 80-130 × 13$23 \mu \mathrm{m}$, hyaline. Secondary chemistry: norstictic acid.
REMARKS-Graphis cleistoblephara belongs to a small group of species ( $G$. dussii aggregate) with very short lirellae being laterally covered by a thick thalline margin but exposing the black, somewhat prominent, upper part of the labia. Graphis dussii Vain. is identical in morphology and chemistry but has transversely septate ascospores ("sporomorph"), while G. scaphella Ach. lacks secondary substances and its ascospores are much shorter. Graphis plagiocarpa is another species of this group, also lacking secondary substances and producing terminally muriform ascospores. Graphis hiascens (Fée) Nyl. is given as synonym of $G$. cleistoblephara by Archer (2007), but G. hiascens supposedly has a laterally carbonized excipulum only. This feature is considered variable by Staiger (2002), but more material is needed to clarify whether one or two taxa are involved. The Australian Graphis lumbschii (A. W. Archer) A. W. Archer) agrees with $G$. cleistoblephara in all features except that, in addition to norstictic acid, protocetraric acid is produced as major secondary substance.

Specimens Seen-COSTA RICA. San José: San Pedro de Montes de Oca, 4 Oct 1929, Thomas 8317 (FH).

\section{Graphis consanguinea (Müll. Arg.) Lücking, comb. nov. Figure 23D.}

Graphina consanguinea Müll. Arg., Nuov. Giorn. Bot. Ital. 21: 362. 1889. Holotype. Brazil, Glaziou s.n. (G!).

Graphis includens Vain., Acta Soc. Fauna Fl. Fenn. 7: 98. 1890; Phaeographina includens (Vain.) Zahlbr., Cat. Lich. Univ. 2: 439. 1923. Holotype. Brazil, Vainio S.n. (TUR-Vainio 27902!; M, isotype; Vainio, Lich. Bras. Exs. 765).

Graphis pseudosophistica Vain., Acta Soc. Fauna F1. Fenn. 7: 104. 1890. Lectotype (fide Staiger 2002: 248). Brazil, Vainio s.n. (M, not seen; TUR-Vainio 27244!, isolectotype; Vainio, Lich, Bras. Exs. 1003).

Graphina heteroplacoides Redinger, Ark. Bot. 26A(1): 38. 1933. Holotype. Brazil, Malme $1227 B$ (s, not seen).

Graphina nylanderiana Zahlbr., Denkschr. Math.Naturw. Klasse K. Akad. Wiss. Wien 83: 111. 1909. Holotype. Brazil., Glaziou $5017 b$ (w!).

Diagnosis-Thallus corticate, smooth to uneven, white-gray. Lirellae immersed-erumpent, partly branched, with complete thalline cover, 1$5 \mathrm{~mm}$ long, 0.4-0.6 mm broad; labia striate (often indistinctly so). Excipulum completely carbonized. Hymenium clear. Ascospores single, muriform, 100-130 × 25-35 $\mu \mathrm{m}$, hyaline. Secondary chemistry: no substances detected by TLC. 
REMARKS-Graphis consanguinea is anatomically similar to $G$. macella and $G$. myrtacea but differs in the morphology of the lirellae: inmersed-erumpent and with complete thalline cover in $G$. consanguinea, prominent and with apically thin thalline layer in G. macella, and erumpent with apically exposed, jet-black labia in $G$. myrtacea. The four names listed here as synonyms of $G$. consanguinea agree well with the type material of the latter: the type of Graphina heteroplacoides was not checked by us but is included as synonym of $G$. consanguinea based on an annotation by M. Wirth in 1961 on the type of G. pseudosophistica. The striation of the labia is often indistinct. but striate labia were found in at least some lirellae of all the specimens studied.

Spectuens Seen-COSTA RICA. Guanacaste: Volcán Tenorio National Park. Alto Masis Section (Arenal-Tilarán Conservation Area). Tilarán Ridge, $85^{\circ} 00^{\prime} \mathrm{W} .10^{\circ} 36^{\prime} \mathrm{N} .850-900 \mathrm{~m}$. lower montane moist forest zone. exposed trees and fence posts and forest regrowth along savanna-like pasture. on bark (lower trunk). 17 Mar 2004. Lücking 17307i (F). Volcán Tenorio National Park. Alto Masis Section (ArenalTilarán Conservation Area), Tilarán Ridge, $85^{\circ} 00^{\prime} \mathrm{W}$ $10^{\circ} 36^{\prime}$ N. 850-900 m. lower montane elfin cloud forest zone, on tree in disturbed forest near Tierras Morenas. 17 Mar 2004. Aptroot 60654 (ABL. INB).

\section{Graphis dendrogramma Nyl. Figure 10C.}

Graphis irradians Nyl.. Acta Soc. Sci. Fenn. 26(10): 21. 1900 [nom. illeg.. ICBN Art. 53.1, non Graphis irradians Fée]: Graphis cevlandica Zahlbr., Cat. Lich. Univ. 2: 297. 1923. Holotype. Sri Lanka [Ceylon], Almquist s.n. (H-Nyl 7900!).

Graphis bougainvillei Zahlbr. in Rechinger. Denkschr. K. Akad. Wiss. Wien Math.-Naturwiss. K1. 88: 18 (1911). Solomon Isls. (Papua New Guinea), Bougainville Isl., 5176 (w!)

Graphis batanensis Vain., Ann. Acad. Sci. Fenn., Ser. A. 15(6): 249. 1921. Holotype. Philippines, McGregor 10209 (TUR-Vainio 27812!).

Graphis subvirginea var. streblicola Vain., Ann. Acad. Sci. Fenn., Ser. A, 15(6): 253. 1921 Holotype. Philippines. Merrill 8529 (TUR-Vainio 27840!).

Graphis subvirginea var. rhi-ophorearum Vain.. Ann. Acad. Sci. Fenn., Ser. A, 15(6): 254. 1921 Holotype. Philippines, McGregor 18421 (TURVainio 27841!).

DiAGNOSIS-Thallus corticate, smooth to uneven, yellowish gray. Lirellae immersed, radiately branched, with lateral thalline margin, 1$5 \mathrm{~mm}$ long, $0.15-0.25 \mathrm{~mm}$ broad; labia entire, white pruinose. Excipulum laterally carbonized. Hymenium clear. Ascospores 8 per ascus, transversely 7-9-septate, $20-30 \times 6-8 \mu \mathrm{m}$, hyaline. Secondary chemistry: stictic and constictic acids.
REMARKS-Graphis dendrogramma is the stictic acid chemomorph of G. caesiella (see comments under that species) and also differs in the usually longer, more radiately branched lirellae. The synonyms listed here all represent exactly the same morphological stage of this taxon, with strongly branched to radiate, immersed, more or less pruinose lirellae. On the type material of $G$. batanensis, an annotation label by Nakanishi indicates this taxon to be identical with $G$. modesta Zahlbr., which then would represent a further synonym of $G$. dendrogramma, but according to Awasthi (1991), the latter has an exposed disc and a completely carbonized excipulum.

Specimens SeEn-COSTA RICA. Guanacaste: Monte Alto, Mirador Section (Tempisque Conservation Area). $700-750 \mathrm{~m}, 10^{\circ} 00^{\prime} \mathrm{N}, 85^{\circ} 23^{\prime} \mathrm{W}, 6$ Jun 2003 , Chaves 613 (INB). Quebrada Azul, Tilarán (Arenal Conservation Area), 700-800 m, 10 $31^{\prime} \mathrm{N}, 84^{\circ} 59^{\prime} \mathrm{W}, 1$ Mar 2003. Chaves 414e (INB). Limón: Cahuita National Park, Puerto Vargas Section (La Amistad Caribe Conservation Area), $82^{\circ} 46^{\prime} \mathrm{W}, 9^{\circ} 40^{\prime} \mathrm{N}$, sea level, lowland coastal moist forest zone, coastal forest remnants and old-growth secondary forest, 24 Mar 2003, Lïcking s.n. (F). Gandoca-Manzanillo Wildlife Refuge. Manzanillo Section (La Amistad Caribe Conservation Area), Manzanillo, $82^{\circ} 53^{\prime} \mathrm{W}, 9^{\circ} 38^{\prime} \mathrm{N}$, sea level. lowland coastal moist forest zone, disturbed coastal vegetation with Cocos mucifera, Coccoloba wifera, on bark (lower trunk), 11 Mar 2004, Lïcking $17102 a(\mathrm{CR}, \mathrm{F})$.

\section{Graphis dimidiata Vain. Figure 18A.}

Graphis dimidiata Vain., Acta Soc. Fauna Fl. Fenn. 7: 108. 1890; Graphina dimidiata (Vain.) Zahlbr., Cat. Lich. Univ. 2: 404. 1923. Lectotype (fide Wirth \& Hale, 1978: 36). Brazil, Vainio 322 (TURVainio 27241!).

DiagNOSIS-Thallus corticate, smooth to uneven, white-gray. Lirellae erumpent, branched, with lateral thalline margin, $1-3 \mathrm{~mm}$ long, $0.2-$ $0.3 \mathrm{~mm}$ broad; labia entire. Excipulum apically (to peripherally) carbonized. Hymenium clear. Ascospores 4-8 per ascus, muriform, 15-30 $\times 8$ $15 \mu \mathrm{m}$, hyaline. Secondary chemistry: no substances detected by TLC.

REMARKS-This species was reported from Costa Rica by Breuss (2000). We found it twice in the present material. The material identified as Graphina dimidiata (Vain.) Zahlbr. in $\mathrm{FH}$ is Graphis cleistoblephara.

Specimens SeEn_COSTA RICA. Alajuela: Volcán Tenorio National Park, Pilón Biological Station (Arenal-Tempisque Conservation Area), Tilarán Ridge, $84^{\circ} 59^{\prime} \mathrm{W}, 10^{\circ} 43^{\prime} \mathrm{N}, 700 \mathrm{~m}$, lower montane 
cloud forest zone, exposed trees and fence posts along pasture, on bark (lower trunk), 15 Mar 2004 Sipman 51856 (B, INB-4054068). Puntarenas: Las Tablas Protection Zone (AC Amistad Pacifico), Los Portones, $25 \mathrm{~km}$ ENE of San Vito, $5 \mathrm{~km}$ on gravel road from Progreso to Las Tablas, roadside, $1600 \mathrm{~m}$, montane rain forest zone; abandoned pasture with dense shrubs and treelets, on bark, 28 June 2002, Sipman 47949b (B, INB).

\section{Graphis disserpens Nyl. Figure 18G-H.}

Graphis disserpens Nyl., Bull. Soc. Linn. Normandie, Sér. 2, 7: 175. 1874 [non Graphis disserpens Vain., nom. illeg.]; Graphina disserpens (Nyl.) Müll. Arg., Flora 63: 23. 1880. Holotype. Colombia [Nova Granata], Lindig 93 (H-Nyl 7415 !).

DiAgNosis - Thallus corticate, smooth to uneven, white-gray. Lirellae erumpent, radiately branched, lacking thalline margin, 3-10 mm long, $0.15-0.25 \mathrm{~mm}$ broad; labia striate. Excipulum apically (to peripherally) carbonized. Hymenium clear. Ascospores $1-4$ per ascus, muriform, 35-46 × 17-24 um, hyaline. Secondary chemistry: no substances detected by TLC.

REMARKS-Graphis disserpens belongs in a difficult group of species requiring further study, all characterized by apically carbonized, striate excipulum and small, muriform ascospores; no lichen substances are produced. Graphis symplecta is most similar but has immersed lirellae with thin thalline cover and presumedly 4-8 ascospore per ascus, this latter character alone not being very reliable. The newly described $G$. paraserpens is morphologically most similar to the latter, but its ascospores are only 8-12 $\mu \mathrm{m}$ broad. Another newly described species, $G$. paradisserpens, has lirellae similar to those of $G$. disserpens but also much narrower ascospores $(10-15 \mu \mathrm{m})$. The material identified as Graphina disserpens (Nyl.) Müll. Arg. in FH is Graphis perstriatula.

SPECIMENS SEEN-COSTA RICA. Alajuela: Santiago y Picacho, 23 Jan 1933, Brenes 16981 (FH). Guanacaste: Palo Verde National Park, Palo Verde Station (Tempisque Conservation Area), Río Tempisque Bassin, $85^{\circ} 21^{\prime} \mathrm{W}, 10^{\circ} 21^{\prime} \mathrm{N}, 10-50 \mathrm{~m}$, lowland to lower montane moist forest zone, disturbed primary forest remnants and open secondary forest, on bark (lower stem), 27 Mar 2003, Sipman 50974b (B, INB). Limón: Gandoca-Manzanillo Wildlife Refuge, Manzanillo Section (La Amistad Caribe Conservation Area), Manzanillo, $82^{\circ} 53^{\prime} \mathrm{W}, 9^{\circ} 38^{\prime} \mathrm{N}$, sea level, lowland coastal moist forest zone, disturbed coastal vegetation with Cocos nucifera, Coccoloba uvifera, on bark (lower trunk), 11 Mar 2004, Lücking $17086 f$ (F), $17105 e(\mathrm{~F})$.
Graphis dracenae Vain. Figure 12C.

Graphis dracenae Vain., Cat. Welwitsch Afr. P1. 2: 439. 1901. Holotype. Africa, Welwitsch 397 (TURVainio 27561!).

Graphis leptocarpa var. invita Vain., Ann. Acad. Sci. Fenn., Ser. A, 15(6): 205. 1921. Holotype. Philippines, Elmer 14926 (TUR-Vainio 27678!)

Graphis immersicans A. W. Archer, Austr. Sist. Bot. 14: 262. 2001. Holotype. Australia. Streimann 31317 (CANB; B, H, US, isotypes!).

DiAGNOSIS--Thallus corticate, smooth to uneven, white-gray. Lirellae erumpent, rarely branched, with lateral thalline margin, 1-3 mm long, 0.1-0.2 mm broad; labia entire. Excipulum (laterally to) completely carbonized. Hymenium clear. Ascospores 8 per ascus, transversely 5-7septate, $20-30 \times 5-7 \mu \mathrm{m}$, hyaline. Secondary chemistry: no substances detected by TLC.

REMARKS-Based on Awashti (1991), we first identified our collections with Graphis assimilis, until detailed study of the available type material suggested otherwise. There are four collections with the name G. assimilis in Nylander's herbarium in Helsinki, none of them marked as type and all belonging to different species. The collection from Singapore ( $\mathrm{H}-\mathrm{Nyl}$ 7122) has prominent. black lirellae lacking or with basal thalline margin and striate labia, completely carbonized excipulum, ascospores 35-50 × 10-12 $\mu \mathrm{m}$, and lacks lichen substances; it is identical with $G$. rimulosa in the $G$. duplicata group. The specimen from New Caledonia ( $\mathrm{H}-\mathrm{Nyl} 7125$ ) features erumpent lirellae with lateral thalline margin and entire labia: ascospores are $30-45 \mu \mathrm{m}$ long. and it contains norstictic acid. This material has been designated as lectotype of $G$. assimilis by Staiger (pers. comm., 2006). The specimen from Sri Lanka (HNyl 7129) has erumpent lirellae with lateral thalline margin and entire labia, completely carbonized excipulum, ascospores $25-45 \times 6$ $9 \mu \mathrm{m}$, and lacks lichen substances. It is identical with the type material of $G$. dracenae Vain. from Africa (TUR-Vainio 27561) and that of $G$. leptocarpa var. invita Vain. from the Philippines (TUR-Vainio 27678) and possibly also with G. immersicans A. W. Archer from Australia (Archer, 2001d). Finally. the material from Colombia (H-Nyl 7134) has erumpent lirellae with lateral thalline margin and entire labia, laterally carbonized excipulum, ascospores $3040 \times 7-9 \mu \mathrm{m}$. and norstictic acid; it is identical with G. pyrrhocheiloides Zahlbr. in the G. scripta group.

Awasthi's (1991) concept of Graphis assimilis agrees with the collection from Sri Lanka ( $\mathrm{H}-\mathrm{Ny}$ 
7129) and the Costa Rican material (lacking norstictic acid), while in the Checklist of Japanese Lichens (Kurokawa, 2003), G. assimilis is considered a synonym of $G$. intricata Fée, which does produce norstictic acid. Nylander's (1868) description of $G$. assimilis circumscribes three of the listed syntypes, but the selection of the New Caledonian material (with norstictic acid) as lectotype agrees with the fact that Nylander's paper refers primarily to New Caledonia as a geographical area. We thus agree with Staiger in selecting the norstictic acid containing specimen from New Caledonia as lectotype. However, contrary to Kurokawa (2003), we do not consider $G$. assimilis a synonym of $G$. intricata since the latter has smaller ascospores with less numerous septa and usually longer, more branched lirellae. Thus, the Costa Rican material, which lacks norstictic acid, must be identified with $G$. dracenae. Archer (2001d, 2006) apparently did not study the collections mentioned above when describing $G$. immersicans, which agrees perfectly with both the type of $G$. dracenae and the Costa Rican material of that species. Müller Argoviensis (1891, 1893a) reported $G$. assimilis from Costa Rica, and also this material represents $G$. dracenae.

Graphis dracenae is morphologically similar to species in the $G$. scripta group, such as $G$. leptocarpa, G. librata, and G. lineola, but differs by its completely carbonized excipulum. Since in other presumedly natural entities, such as the $G$. duplicata and $G$. insulana groups, closely related taxa can have either laterally or completely carbonized excipula and some species vary regarding this feature, it might be necessary to include $G$. dracenae and related species in the $G$. scripta group.

Specimens SeEn-COSTA RICA. Guanacaste: Las Delicias below Hacienda Santamaria, 380-400 m, 18 Jan 1930, Dodge \& Thomas 6889 (FH). Limón: Gandoca-Manzanillo Wildlife Refuge, Manzanillo Section (La Amistad Caribe Conservation Area), Manzanillo, $82^{\circ} 53^{\prime} \mathrm{W}, 9^{\circ} 38^{\prime} \mathrm{N}$, sea level, lowland coastal moist forest zone, disturbed coastal vegetation with Cocos nucifera, Coccoloba uvifera, on bark (lower trunk), 11 Mar 2004, Lücking $17102 b$ (F).

\section{Graphis dupaxana Vain. Figure 12G.}

Graphis dupaxana Vain., Ann. Acad. Sci. Fenn., Ser. A. 15(6): 241. 1921. Lectoype (fide Nakanishi, annotation label in 1973). Philippines, McGregor 14313 (TUR-Vainio 27869!).

Graphis moultonii Vain., Ann. Acad. Sci. Fenn., Ser. A, 15(6): 243. 1921. Holotype. Indonesia (Borneo: Sarawak), Moulton s.n. (TUR-Vainio 27859!).
DiAGNOSIS-Thallus corticate, smooth to uneven, white-gray. Lirellae prominent, unbranched, lacking thalline margin, $1-4 \mathrm{~mm}$ long, $0.15-0.25 \mathrm{~mm}$ broad; labia striate. Excipulum completely carbonized. Hymenium clear. Ascospores 8 per ascus, transversely 7-9-septate, 25$35 \times 7-9 \mu \mathrm{m}$, hyaline. Secondary chemistry: no substances detected by TLC.

REMARKS-Graphis dupaxana is very similar and closely related to $G$. duplicata, the two differing mainly in the completely versus laterally carbonized excipulum. In the G. duplicata group, this feature is somewhat variable, and there are species with mostly completely but sometimes laterally carbonized excipulum only (e.g., $G$. longula) and vice versa (e.g., G. leptoclada) in the same specimen. In the case of $G$. duplicata versus $G$. dupaxana, the two seem to be rather well distinguished based on the collections known so far and are therefore kept separate. Nakanishi (on label) annotated the type of Graphis dupaxana to be a synonym of $G$. schizograpta Müll. Arg. We have studied the latter, and it has a laterally carbonized excipulum only; it therefore is different from $G$. dupaxana but a synonym of $G$. duplicata.

Specimens SeEN-COSTA RICA. Limón: GandocaManzanillo Wildlife Refuge, Manzanillo Section (La Amistad Caribe Conservation Area), Manzanillo, $82^{\circ} 53^{\prime} \mathrm{W}, 9^{\circ} 38^{\prime} \mathrm{N}$, sea level, lowland coastal moist forest zone, disturbed coastal vegetation with Cocos nucifera, Coccoloba uvifera, on bark (lower trunk), 11 Mar 2004, Lücking 17105n (CR, F, INB, USJ). Puntarenas: Corcovado National Park, Sirena Section, Sirena Biological Station (Osa Conservation Area), Osa Peninsula, $83^{\circ} 35^{\prime} \mathrm{W}, 8^{\circ} 29^{\prime} \mathrm{N}$, sea level, lowland coastal rain forest zone, coastal secondary forest and closed secondary vegetation on sandy soil, on bark (lower trunk), 7 Apr 2003, Buck 44123 (INB, NY).

\section{Graphis duplicata Ach. Figure 9D.}

Graphis duplicata Ach., Syn. Meth. Lich.: 81. 1814. Lectotype (fide Hale, annotation label in 1970; Staiger, 2002: 229). South America, unknown locality, s.col. (H-Ach 586!).

Graphis schizograpta Müll. Arg., Flora 65: 335. 1882. Syntypes. Indonesia (Java), s.col. (G!).

Graphis lopingensis Zahlbr. in Handel-Mazzetti, Symb. Sin. 3: 48. 1930. Holotype. China (Yunnan), Handel-Mazzetti 10213 (w!).

Graphis lussuensis Zahlbr. in Handel-Mazzetti, Symb. Sin. 3: 49. 1930. Holotype. China (Yunnan), Handel-Mazzetti 9103 (w!; Us, isotype!).

Graphis bicrenatula Redinger, Ark. Bot. 27(3): 37. 1935; Graphis bicrenulata Redinger in Spielmann, Caderno Pesquisa 18: 44. 2006 [orth. error]. Holotype. Brazil, Malme 640 (s 6508!). 
DiAGNOSIS-Thallus corticate, smooth to uneven, white-gray. Lirellae erumpent, partly branched, lacking thalline margin, 1-6 mm long, $0.2-0.3 \mathrm{~mm}$ broad; labia striate. Excipulum laterally carbonized. Hymenium clear. Ascospores 8 per ascus, transversely 7-11-septate, $25-45 \times 6-8 \mu \mathrm{m}$, hyaline. Secondary chemistry: no substances detected by TLC.

REMARKS-This common taxon forms the center of the Graphis duplicata group, characterized by usually prominent, striate lirellae lacking thalline cover and small to medium-sized ascospores. Contrary to the G. scripta and G. insulana groups, most of the species in the $G$. duplicata group lack secondary substances and hymenium inspersion. The type material of the synonyms listed here all fit $G$. duplicata rather well. Archer (2006) also gave $G$. leptoclada as a synonym (which is a replacement name for Opegrapha rimulosa Mont. \& Bosch, nom. illeg.; non Opegrapha rimulosa Mont.), but that taxon has a lateral thalline margin and slightly larger ascospores and is here accepted as distinct species, with $G$. ridigula as synonym (see below).

The specimens identified as $G$. duplicata in $\mathrm{FH}$ are a mixture of that species and G. puiggarii.

Specimens Seen-COSTA RICA. Alajuela: San Pedro de San Ramón, 9 Jan 1934, Brenes 18913 (FH). Cartago: Tapantí National Park (La Amistad Pacífico Conservation Area), trail to waterfall, $1400-1500 \mathrm{~m}$, $9^{\circ} 44^{\prime} \mathrm{N}, 83^{\circ} 47^{\prime} \mathrm{W}, 2$ Apr 2003, Chaves 510 (INB); Tapantí Section, Tapantí Station (La Amistad Pacífico Conservation Area), Talamanca Ridge, $83^{\circ} 47^{\prime} \mathrm{W}$, $9^{\circ} 45^{\prime} \mathrm{N}, 1300-1400 \mathrm{~m}$, montane rain forest zone, closed primary forest and roadside, on bark (lower trunk), 2 Apr 2003, Lücking 16593 (F, INB); on bark (branch), 2 Apr 2003, Lücking 16570 (F). Guanacaste: Along Rio Liberia NE of Liberia, 100 m, 13 Jan 1930, Dodge et al. s.n. (FH). Monte Alto Forest Reserve, Cerro Romo (Tempisque Conservation Area), Nicoya Peninsula, $85^{\circ} 24^{\prime} \mathrm{W}, 10^{\circ} 00^{\prime} \mathrm{N}, 750-900 \mathrm{~m}$, lowland to lower montane moist forest zone, forest regrowth along pasture, on bark (lower trunk), 22 Mar 2004, Sipman 52065 (B, INB). Volcán Tenorio National Park, Alto Masis Section (Arenal-Tilarán Conservation Area), Tilarán Ridge, $85^{\circ} 00^{\prime} \mathrm{W}, 10^{\circ} 37^{\prime} \mathrm{N}, 950-$ $1000 \mathrm{~m}$, lower montane elfin cloud forest zone, disturbed low elfin forest and secondary vegetation, on bark (lower stem), 17 Mar 2004, Lücking 17323b (CR, F, USJ); on bark (lower trunk), 17 Mar 2004, Lücking $17324 \mathrm{c}$ (F); on bark (twig), 17 Mar 2004, Lücking 17330 (F, USJ). Heredia: La Selva Protection Zone, La Selva Biological Station (Cordillera Volcánica Central Conservation Area), Volcánica Central Ridge, $84^{\circ} 03^{\prime} \mathrm{W}, 10^{\circ} 26^{\prime} \mathrm{N}, 50 \mathrm{~m}$, lowland rain forest zone, trees along main road, on bark (lower stem), 15 Jun 2002, Lücking 15026d (F, INB). Limón: GandocaManzanillo Wildlife Refuge, Manzanillo Section (La Amistad Caribe Conservation Area), Manzanillo, $82^{\circ} 53^{\prime} \mathrm{W}, 9^{\circ} 38^{\prime} \mathrm{N}$, sea level, lowland coastal moist forest zone, disturbed coastal vegetation with Cocos nucifera, Coccoloba uvifera, on bark (lower trunk), 11 Mar 2004, Lücking 17105 o (CR, F, USJ). Hitoy Cerere Biological Reserve, Hitoy Cerere Biological Station (La Amistad Caribe Conservation Area), Talamanca Ridge, $83^{\circ} 02^{\prime} \mathrm{W}, 9^{\circ} 40^{\prime} \mathrm{N}, 100-150 \mathrm{~m}$, lowland to lower montane rain forest zone, exposed trees and fence posts along pasture, on bark (branch), 10 Mar 2004, Aptroot 60288 (ABL, INB); on bark (branch, fallen), 10 Mar 2004, Sipman 51682 (B, INB); on wood (fence post), 10 Mar 2004, Aptroot 60239 (ABL, INB), Sipman 51672 (B, INB); $150 \mathrm{~m}$, lowland to lower montane rain forest zone, secondary vegetation and disturbed primary forest along river, on bark (lower trunk), 9 Mar 2004, Lücking 17000d (F, INB). Puntarenas: Las Tablas Protection Zone, Los Portones Section (La Amistad Pacífico Conservation Area), Talamanca Ridge, $82^{\circ} 48^{\prime} \mathrm{W}, 8^{\circ} 54^{\prime} \mathrm{N}, 1400 \mathrm{~m}$, lower montane rain forest zone, pasture with scattered, small trees, on bark (lower trunk), 28 Jun 2002, Sipman 47991g (B, INB); $82^{\circ} 48^{\prime} \mathrm{W}, 8^{\circ} 55^{\prime} \mathrm{N}, 1500 \mathrm{~m}$, lower montane rain forest zone, pasture and margin of disturbed remnants of primary forest, on bark (lower stem), 28 Jun 2002, Lücking 1515le (F, INB); $82^{\circ} 48^{\prime} \mathrm{W}, 8^{\circ} 55^{\prime} \mathrm{N}, 1600 \mathrm{~m}$, montane rain forest zone, abandoned roadside pasture with dense shrubs and treelets, on bark (lower stem), 28 Jun 2002, Sipman 47938 (B, INB). Monteverde Cloud Forest Reserve (Arenal Conservation Area), $1500-1600 \mathrm{~m}, 10^{\circ} 18^{\prime} \mathrm{N}, 84^{\circ} 47^{\prime} \mathrm{W}, 19 \mathrm{Jan} 2003$, Chaves 253 (INB). San José: Universidad de Costa Rica Campus (Cordillera Volcánica Central Conservation Area), Central Valley, San José, $84^{\circ} 03^{\prime} \mathrm{W}, 9^{\circ} 56^{\prime} \mathrm{N}$, $1200 \mathrm{~m}$, lower montane moist forest zone, planted trees on campus, on bark (lower trunk), 20 Jun 2002, Lücking 15035d (F, USJ).

Graphis duplicatoinspersa Lücking, sp. nov. Figure 11D.

Sicut Graphis duplicata sed hymenio insperso differt. Holotype. COSTA RICA. Alajuela: Volcán Tenorio National Park, Pilón Biological Station (Arenal-Tempisque Conservation Area), Tilarán Ridge, $84^{\circ} 59^{\prime} \mathrm{W}, 10^{\circ} 43^{\prime} \mathrm{N}, 700 \mathrm{~m}$, lower montane cloud forest zone, exposed trees and fence posts along pasture, on bark (lower stem), 15 Mar 2004, Lücking 17214d (F, holotype).

Paratype. Alajuela: Volcán Tenorio National Park, Pilón Biological Station (Arenal-Tempisque Conservation Area), Tilarán Ridge, $84^{\circ} 59^{\prime} \mathrm{W}$, $10^{\circ} 43^{\prime} \mathrm{N}, 700 \mathrm{~m}$, lower montane cloud forest zone, grazed, abandoned Syzygium jambos plantation surrounded by Gmelina arborea trees and pasture fields, 15 Mar 2004, Sipman 51803a (B).

DESCRIPTION-Thallus corticolous, $1-2 \mathrm{~cm}$ diam., $30-50 \mu \mathrm{m}$ thick, continuous; surface uneven, pale gray; prothallus absent. Thallus in section with cartilaginous upper cortex, irregular algal layer and clusters of crystals. Apothecia lirelliform, flexuose, partly branched, erumpent to prominent, lacking or with thin basal thalline margin, 1-3 mm long, $0.15-0.25 \mathrm{~mm}$ wide, 0.1 - 
$0.2 \mathrm{~mm}$ high; disc concealed; proper margin thick, labia striate, black; thalline margin absent or basally developed only. Excipulum crenulate, laterally (to almost completely) carbonized, 50$100 \mu \mathrm{m}$ wide, black; hypothecium prosoplectenchymatous, 5-10 $\mu \mathrm{m}$ high, colorless; hymenium 70-100 $\mu \mathrm{m}$ high, inspersed (type A); epithecium indistinct. Paraphyses unbranched; asci ellipsoid, $70-90 \times 20-30 \mu \mathrm{m}$. Ascospores 8 per ascus, ellipsoid to fusiform with rounded ends, transversely 7-11-septate, $25-35 \times 5-7 \mu \mathrm{m}, 4-6$ times as long as wide, colorless. Secondary chemistry: no substances detected by TLC.

REMARKS - Species with inspersed hymenium are comparatively rare in the genus Graphis and restricted chiefly to the G. scripta, G. insulana, and $G$. acharii groups. In spite of studying over 600 available names, we have not yet seen a species of the $G$. duplicata group with inspersed hymenium, and so the discovery of this apparently undescribed taxon comes as a surprise. Graphis duplicatoinspersa is very similar to $G$. duplicata, except for the inspersed hymenium and the sometimes almost completely carbonized excipulum. Having a taxon with inspersed hymenium in this rather large group of species with typically clear hymenium is somewhat comparable to the situation in the G. nuda group, which also contains a single species with inspersed hymenium, $G$. anfractuosa.

Redinger (1935) described Graphis inspersa as differing from $G$. duplicata only by the inspersed hymenium. We have examined the type, and the species is based on two misconceptions: the labia are entire and not striate as indicated by Redinger (1935), and the concept of $G$. duplicata as having immersed lirellae with lateral thalline margin is incorrect. In addition, $G$. inspersa produces norstictic acid. It is thus conspecific with $G$. tenellula (see below).

ECOLOGY - So far known from lower montane cloud forest in rather exposed situations.

\section{Graphis elegans (Sm.) Ach. Figure 5D, 10H.}

Graphis elegans (Sm.) Ach., Syn. Meth. Lich.: 85. 1814; Opegrapha elegans Sm. in Sowerby \& Smith, Engl. Bot.: 26. 1808; Aulacographa elegans (Sm.) Leight., Ann. Mag. Nat. Hist., Ser. 2, 13: 389. 1854. Holotype. Great Britain (England), Borrer s.n. (BM, not seen).

DiAGNOSIS-Thallus corticate, smooth to uneven, white-gray. Lirellae erumpent to prominent, partly branched, lacking thalline margin, $1-3 \mathrm{~mm}$ long, $0.5-0.7 \mathrm{~mm}$ broad; labia striate. Excipulum laterally carbonized. Hymenium clear. Ascospores 8 per ascus, transversely 9-13-septate, 35$60 \times 9-13 \mu \mathrm{m}$, thick-walled, hyaline to pale graybrown, I+ violet-blue. Secondary chemistry: norstictic and connorstictic acids.

REMARKS-This species features rather thickwalled, often slightly brownish ascospores somewhat deviating from the bulk of Graphis species, although similar ascospores were found in a few other, morphologically very different taxa (Fig. 5D). However, as a whole, G. elegans intergrades well with other species of the genus. Its lirellae are typical for a member of the $G$. duplicata group, and the morphologically similar G. lumbricina, with larger but otherwise similar ascospores, connects $G$. elegans with the $G$. acharii group. The specimen from Venezuela marked with an * listed under $G$. elegans in Staiger (2002: 233) might represent G. lumbricina; it is said to have larger ascospores of a size characteristic of that species, although the two taxa also differ in excipulum carbonization.

Graphis elegans was previously reported from Costa Rica by Breuss (2001).

Specimens SEen-COSTA RICA. Alajuela: Huetar Norte, Boca Tapada, Refugio Nacional de Vida Silvestre Mixto Maquenque, $0-100 \mathrm{~m}, 10^{\circ} 42^{\prime} \mathrm{N}$, $84^{\circ} 11^{\prime} \mathrm{W}, 8$ May 2005, Chaves 2317 (INB). Cartago: Genesis II Cloud Forest Reserve (La Amistad Pacífico Conservation Area), Talamanca Ridge, 2200-2500 m, montane rain forest to upper montane cloud forest zone, Feb 1997, Lücking 97-54 (F). San José: Universidad de Costa Rica Campus (Cordillera Volcánica Central Conservation Area), Central Valley, San José, $84^{\circ} 03^{\prime} \mathrm{W}, 9^{\circ} 56^{\prime} \mathrm{N}, 1200 \mathrm{~m}$, lower montane moist forest zone, planted trees on campus, on bark (lower trunk), 8 Mar 2004, Aptroot 60045 (ABL, USJ).

Graphis dichotoma (Müll. Arg.) Lücking, comb. nov. Figure 21B.

Graphina dichotoma Müll. Arg., Flora 63: 23. 1880. Holotype. Brazil, Puiggari 508 (G!).

Graphina elongatoradians Fink, Mycologia 19: 312. 1927. Holotype. Puerto Rico, Fink 2049 (MICH, not seen).

DiAGNOSIS - Thallus corticate, smooth to uneven, white-gray. Lirellae erumpent, stellately branched, with lateral thalline margin, $1-10 \mathrm{~mm}$ long, $0.1-0.2 \mathrm{~mm}$ broad; labia striate. Excipulum laterally carbonized. Hymenium clear. Ascospores 2-6 per ascus, muriform, 25-35 $\times 10$ $13 \mu \mathrm{m}$, hyaline. Secondary chemistry: no substances detected by TLC.

REMARKS-This taxon is often found on wood and, besides anatomical details, character- 
ized by its elongated, radiately branching, narrow lirellae, also seen in the type material of Graphina elongatoradians. The epithets of both synonyms are thus quite appropriate. The species is not a synonym of Graphis elongata Vain., as suggested by Wirth \& Hale (1963) since the latter produces norstictic acid. Graphina dichotoma is one of three original species in the protologue of Graphina (Lücking et al., 2007c).

Material from FH identified by Dodge as Graphina errescens Redinger and Graphis grammitica Nyl. represents typical G. dichotoma.

Specimens SeEn_COSTA RICA. Alajuela: San Ramón, Feb 1931, Brenes 14486a (FH). Volcán Tenorio National Park, Pilón Biological Station (Arenal-Tempisque Conservation Area), Tilarán Ridge, $84^{\circ} 59^{\prime} \mathrm{W}, 10^{\circ} 43^{\prime} \mathrm{N}, 700 \mathrm{~m}$, lower montane cloud forest zone, exposed trees and fence posts along pasture, on bark (lower trunk), 15 Mar 2004, Aptroot 60460 (ABL, INB-3964137); on wood (fence post), 16 Mar 2004, Lücking $17250 \mathrm{~g}$ (F, USJ). Cartago: Potrero and bananal below railroad, 920-1100 m, 9 Oct 1929 , Dodge 8321 (FH). Guanacaste: Novasa Wind Power Project (Arenal-Tilarán Conservation Area), Tilarán Ridge, Tierras Morenas, $85^{\circ} 01^{\prime} \mathrm{W}, 10^{\circ} 38^{\prime} \mathrm{N}, 750 \mathrm{~m}$, lower montane moist forest zone, exposed trees and fence posts along pasture, on wood (fence post), 23 Mar 2004, Lücking 17706 (F). Volcán Tenorio National Park, Alto Masis Section (Arenal-Tilarán Conservation Area), Tilarán Ridge, $85^{\circ} 00^{\prime} \mathrm{W}$, $10^{\circ} 37^{\prime} \mathrm{N}, 950-1000 \mathrm{~m}$, lower montane elfin cloud forest zone, disturbed low elfin forest and secondary vegetation, on bark (lower stem), 17 Mar 2004, Sipman 51916 (B, INB). Limón: Gandoca-Manzanillo Wildlife Refuge, Manzanillo Section (La Amistad Caribe Conservation Area), Manzanillo, $82^{\circ} 53^{\prime} \mathrm{W}, 9^{\circ} 38^{\prime} \mathrm{N}$, sea level, lowland coastal moist forest zone, disturbed coastal vegetation with Cocos nucifera, Coccoloba uvifera, on bark (trunk base), 11 Mar 2004, Lücking 17081 (F). Puntarenas: Las Cruces Biological Station and Wilson Botanical Garden near San Vito, 900$1000 \mathrm{~m}$, montane rain forest zone, planted vegetation and disturbed forest, 10-24 Oct 2004, Lücking 18011 (F), 18034 (CR, F, USJ), Sipman 53285 (B, INB-3993692), 53346 (B, INB-3997424), 53398 (B, INB-3993924). Las Tablas Protection Zone, Cedro Ridge, Las Alturas Station (La Amistad Pacífico Conservation Area), Talamanca Ridge, $82^{\circ} 50^{\prime} \mathrm{W}, 8^{\circ} 57^{\prime} \mathrm{N}, 1500 \mathrm{~m}$, lower montane rain forest zone, reforestation plot (Cedrela odorata) bordering pasture, on bark (lower trunk), 26 Jun 2002, Lücking 15091aa (F).

Graphis emersa Müll. Arg. Figure 14G-H.

Graphis emersa Müll. Arg., Hedwigia 32: 132. 1893. Holotype. Australia, Bailey 217 (G!).

DiAGNOSIS-Thallus corticate, smooth to uneven, white-gray. Lirellae sessile, unbranched, lacking thalline margin, jet-black, Melaspilealike, $0.5-2 \mathrm{~mm}$ long, $0.1-0.2 \mathrm{~mm}$ broad; labia entire. Excipulum completely carbonized. Hyme- nium clear. Ascospores 8 per ascus, transversely 7-11-septate, 30-40 × 7-9 $\mu \mathrm{m}$, hyaline. Secondary chemistry: norstictic acid.

REMARKS - This species was originally described by Müller Argoviensis (1893b) from Australia (Archer, 2006) but simultaneously reported from Costa Rica (Müller Argoviensis, 1893a). We have not seen the material and thus cannot confirm this report, but since the species is very characteristic and unlikely to be confused with other species represented in Costa Rica, we rely on Müller Argoviensis. Graphis emersa is a typical member of the G. nuda group, closely resembling $G$. virescens in morphology and ascospore size, but is the only species in this group that produces norstictic acid.

\section{Graphis farinulenta Müll. Arg. Figure 9F}

Graphis farinulenta Müll. Arg., Bull. Soc. Roy. Bot. Belg. 30: 80. 1891. Lectotype (here selected). Costa Rica, Pittier 5146 (G!). Paratype. Costa Rica, Pittier 5329 (G!).

DiAGNosis-Thallus ecorticate, farinose, bluish white-gray. Lirellae prominent, partly branched, with lateral thalline margin, $1-5 \mathrm{~mm}$ long, 0.2 $0.3 \mathrm{~mm}$ broad; labia entire (to striate), white pruinose. Excipulum laterally carbonized. Hymenium clear. Ascospores $4-8$ per ascus, transversely 9-13-septate, 60-80 × 9-11 $\mu \mathrm{m}$, hyaline. Secondary chemistry: no substances detected by TLC.

REMARKS - This species, originally described from Costa Rica, is very similar to Graphis pavoniana but differs by its prominent lirellae and longer ascospores (up to $80 \mu \mathrm{m}$ ). Graphis seminuda is another closely related taxon that differs chiefly in its completely carbonized excipulum. The original material consists of three syntypes (Pittier 5146 here selected as lectotype) that originate from two probably adjacent collections in the same place and are perfectly identical. We have also re-collected this taxon in the present inventory, rather close to the type locality, which indicates a distribution possibly restricted to the dry areas of Guanacaste. One specimen was found with shallowly striate labia but otherwise agrees perfectly with Graphis farinulenta in thallus and labia morphology and ascospore type. A section showed that the labia are pseudostriate; that is, the striation is not caused by the formation of new hymenia. We therefore include the material here in G. farinulenta, although this character is rather untypical for species of the G. scripta group. On the other hand, the $G$. farinulenta aggregate also shows 
affinities with the $G$. acharii group, as indicated by molecular data (Staiger et al., 2006), and the latter typically has striate labia.

The material from Costa Rica identified with this name by Dodge is a mixture of Carbacanthographis marcescens (Fée) Staiger \& Kalb and Graphis duplicata, two taxa that have little in common with $G$. farinulenta.

SpeCimens SeEn-COSTA RICA. Guanacaste: Barra Honda National Park, Barra Honda Biological Station (Tempisque Conservation Area), Barra Honda Mountains, $85^{\circ} 21^{\prime} \mathrm{W}, 10^{\circ} 10^{\prime} \mathrm{N}, 400-500 \mathrm{~m}$, lowland to lower montane moist forest zone, disturbed primary and old-growth secondary forest with calcareous rock outcrops, on bark (lower stem), 22 Mar 2004, Lücking $17550 a$ (CR, F), $17550 b$ (CR, F, INB, USJ), $17556 a$ (F, INB), $17557 b$ (CR, F, INB, USJ); on bark (lower trunk), 22 Mar 2004, Lücking 17554 (CR, F, INB, USJ), Sipman 52040 (B, INB). Lomas de Barbudal Biological Reserve, Lomas de Barbudal Station (Tempisque Conservation Area), Río Tempisque Bassin, $85^{\circ} 22^{\prime} \mathrm{W}, 10^{\circ} 30^{\prime} \mathrm{N}$, $100 \mathrm{~m}$, lowland to lower montane moist forest zone; disturbed gallery forest and forest remnants, on bark (lower stem), 29 Mar 2003, Sipman 51045c (B, USJ). Palo Verde National Park (Tempisque Conservation Area), Río Tempisque Bassin, $85^{\circ} 21^{\prime} \mathrm{W}, 10^{\circ} 21^{\prime} \mathrm{N}, 10-$ $50 \mathrm{~m}$, lowland to lower montane moist forest zone; disturbed primary forest remnants and open secondary forest, on bark (lower trunk), 28 Mar 2003, Sipman 50955 (B, INB), $50997 b$ (B, INB), 51001 (B, CR). Limón: Hitoy Cerere Biological Reserve, Hitoy Cerere Biological Station (La Amistad Caribe Conservation Area), Talamanca Ridge, $83^{\circ} 02^{\prime} \mathrm{W}, 9^{\circ} 40^{\prime} \mathrm{N}, 150 \mathrm{~m}$, lowland to lower montane rain forest zone, secondary vegetation and disturbed primary forest along river, on bark (lower trunk), 9 Mar 2004, Lücking 17001 (CR, F). Puntarenas: Carara National Park, Quebrada Bonita Section (Pacífico Central Conservation Area), $84^{\circ} 35^{\prime} \mathrm{W}, 9^{\circ} 47^{\prime} \mathrm{N}, 100 \mathrm{~m}$, lowland moist forest zone, partly disturbed dense primary forest with understory dominated by Erythrochiton gymnanthus, on bark (lower trunk), 18 Jul 2002, Sipman 48382e (B, INB).

\section{Graphis firferi Lücking, sp. nov. Figure 7E.}

Sicut Graphis rhizocola sed apotheciis pruina flava instructis differt. Holotype. COSTA RICA. Puntarenas: La Amistad International Park, Altamira Station (La Amistad Pacífico Conservation Area), Talamanca Ridge, $83^{\circ} 00^{\prime} \mathrm{W}, 9^{\circ} 02^{\prime} \mathrm{N}, 1500-$ $1600 \mathrm{~m}$, montane rain forest zone, disturbed primary forest and secondary vegetation dominated by Cecropia, on bark (lower trunk), 30 Jun 2002, Lücking 15216 (F, holotype).

Paratypes. COSTA RICA. Guanacaste: Tilarán, Parcelas, Quebrada Azul, (Arenal-Tempisque Conservation Area), $84^{\circ} 58^{\prime} \mathrm{W}, 10^{\circ} 30^{\prime} \mathrm{N}, 700 \mathrm{~m}$, borders of way and areas of pasturing, on bark (lower trunk), 1 March 2003, Chaves 414d (INB3773636). Puntarenas: La Amistad International Park, Altamira Station (La Amistad Pacífico Conservation Area), Talamanca Ridge, $83^{\circ} 00^{\prime} \mathrm{W}, 9^{\circ} 02^{\prime} \mathrm{N}, 1500-1600 \mathrm{~m}$, montane rain forest zone, disturbed primary forest and secondary vegetation dominated by Cecropia, on bark (lower trunk), 30 Jun 2002, Lücking 15212d (F, CR), $15273 c(\mathrm{~F})$.

DESCRIPTION-Thallus corticolous, $2-5 \mathrm{~cm}$ diam., $70-150 \mu \mathrm{m}$ thick, continuous; surface uneven, pale greenish gray; prothallus absent. Thallus in section with cartilaginous upper cortex, irregular algal layer and clusters of crystals. Apothecia lirelliform, flexuose, partly branched, prominent, lacking or with thin complete thalline margin, 3-10 $\mathrm{mm}$ long, 0.4$0.6 \mathrm{~mm}$ wide, $0.3-0.4 \mathrm{~mm}$ high; disc concealed; proper margin thick, labia entire, gray to black but with thin, pale yellow, $\mathrm{K}+$ yellow to salmon pruina (purple when dried); thalline margin absent or thin. Excipulum entire, completely carbonized, $80-150 \mu \mathrm{m}$ wide, black; hypothecium prosoplectenchymatous, $10-20 \mu \mathrm{m}$ high, colorless to pale yellowish; hymenium 150$200 \mu \mathrm{m}$ high, colorless, clear; epithecium indistinct. Paraphyses unbranched; asci clavate, 120 $170 \times 25-35 \mu \mathrm{m}$. Ascospores 4-8 per ascus, oblong, transversely 11-19-septate, 70-100 $\times$ 11-15 $\mu \mathrm{m}, 6-7$ times as long as wide, colorless to slightly grayish brown. Secondary chemistry: unknown anthraquinone.

ETYMOLOGY - This beautiful new species is dedicated to the Firfer family, Chicago, for their enthusiastic support of this monograph and The Field Museum and for giving us the possibility to publish the color plate, which includes a photograph of the new species.

REMARKS-Species of Graphis with anthraquinone pigments are relatively rare, and neotropical collections can usually be identified with the two common taxa $G$. chrysocarpa and $G$. subchrysocarpa. Both species have a bright orange pruina that reacts $\mathrm{K}+$ pink-purple. Graphis firferi agrees in most features with these two taxa, except that the labia are always entire, the pigment covering the labia is pale yellow and reacts $\mathrm{K}+$ yellow to salmon (eventually purplish after several minutes), and the ascospores are transversely septate only. The latter, together with the entire labia, suggest a close relationship with $G$. rhizocola. Two more species have been discovered with the same type of pigment: $G$. flavominiata has slightly longer, terminally muriform ascospores, while those of $G$. flavoaltamirensis are distinctly muriform, the latter also differs by its striate labia and inspersed hymenium. Interestingly, all three new species where collected in more or less the same region. 
ECOLOGY - Apparently a montane rain forest species.

\section{Graphis flavens Müll. Arg. Figure 13D.}

Graphis flavens Müll. Arg., Flora 65: 334. 1882. Holotype. Indonesia (Java), Junghuhn 446 (L, holotype; $\mathrm{G}$, isotype!).

Graphis angustata var. denudata Vain., Ann. Acad. Sci. Fenn., Ser. A, 6: 158. 1915. Holotype. Guadeloupe, Duss 530 (TUR-Vainio 27845!).

Graphis subintegra Redinger, Ann. Mycol. 31: 172. 1933. Holotype. Indonesia (Java), Kjellberg $101 \mathrm{~L}$ (s 2166!).

Graphis atrolabiata Chaves \& Lücking [nom inval., ICBN Art. 32, 35-37].

DIAGNOSIS - Thallus corticate, smooth to uneven, white-gray. Lirellae prominent, rarely branched, with thick lateral thalline margin, 1$5 \mathrm{~mm}$ long, $0.2-0.3 \mathrm{~mm}$ broad; labia entire, sharply delimited, jet-black. Excipulum completely carbonized. Hymenium clear. Ascospores 4-8 per ascus, transversely 11-15-septate, 60-65 $\times$ 9-11 $\mu \mathrm{m}$, hyaline. Secondary chemistry: no substances detected by TLC.

REMARKS-Graphis flavens recalls G. rustica because of its prominent lirellae with rather thick lateral thalline margin and sharply delimited, jetblack labia but differs from the latter in the smaller ascospores and lack of lichen substances. We first intended to describe the Costa Rican material as new species (and the name $G$. atrolabiata was included in our Internet keys; www.fieldmuseum.org/ticolichen/keys_graphis. html) but eventually could not find any convincing differences compared to the eastern paleotropical material. Graphis oxyclada is very similar in morphology and also lacks secondary substances but has narrower lirellae and small ascospores.

Specimens Seen_COSTA RICA. Alajuela: Volcán Tenorio National Park, Pilón Biological Station (Arenal-Tempisque Conservation Area), Tilarán Ridge, $84^{\circ} 59^{\prime} \mathrm{W}, 10^{\circ} 43^{\prime} \mathrm{N}, 700-900 \mathrm{~m}$, lower montane cloud forest zone, partly disturbed primary forest, on bark (root), 16 Mar 2004, Lücking 17266 (CR, F, INB). Cartago: Tapantí National Park (La Amistad Pacífico Conservation Area), trail to waterfall, 1400-1500 m, $9^{\circ} 44^{\prime} \mathrm{N}, 83^{\circ} 47^{\prime} \mathrm{W}, 2$ Apr 2003, Chaves 497 (INB); Tapantí Section, Tapantí Station (La Amistad Pacífico Conservation Area), Talamanca Ridge, $83^{\circ} 47^{\prime} \mathrm{W}$, $9^{\circ} 44^{\prime} \mathrm{N}, 1700 \mathrm{~m}$, montane cloud forest zone, primary forest margin along roadside, on bark (lower trunk), 11 Apr 2003, Buck 44148 (INB, NY); $83^{\circ} 47^{\prime} \mathrm{W}, 9^{\circ} 45^{\prime} \mathrm{N}$, 1400-1600 m, montane rain forest zone, closed primary forest and roadside, on bark (branch), 2 Apr 2003, Lücking 16573 (F); on bark (branch, fallen), 2 Apr 2003, Lücking 16580a (F, INB); on bark (lower trunk), 2 Apr 2003, Lücking 16567 (F). Guanacaste: Santa Elena Reserve (Arenal Conservation Area), 900-1000 m, $10^{\circ} 21^{\prime} \mathrm{N}, 84^{\circ} 46^{\prime} \mathrm{W}$, cloud forest, 14 Jan 2003, Chaves 111d (INB), $112 a$ (INB). Volcán Tenorio National Park, Alto Masis Section (Arenal-Tilarán Conservation Area), Tilarán Ridge, $85^{\circ} 00^{\prime} \mathrm{W}, 10^{\circ} 37^{\prime} \mathrm{N}, 950-$ $1000 \mathrm{~m}$, lower montane elfin cloud forest zone, disturbed low elfin forest and secondary vegetation, on bark (branch), 17 Mar 2004, Lücking 17325 (CR, F, INB, USJ). Puntarenas: Las Cruces Biological Station and Wilson Botanical Garden near San Vito, 900$1000 \mathrm{~m}$, montane rain forest zone, planted vegetation and disturbed forest, 10-24 Oct 2004, Lücking 18033 (F). San José: Universidad de Costa Rica Campus (Cordillera Volcánica Central Conservation Area), Central Valley, San José, $84^{\circ} 03^{\prime} \mathrm{W}, 9^{\circ} 56^{\prime} \mathrm{N}, 1200 \mathrm{~m}$, lower montane moist forest zone, planted trees on campus, on bark (lower stem), 20 Jun 2002, Lücking $15051 i$ (INB).

\section{Graphis flavoaltamirensis Sipman \& Lücking, sp.} nov. Figure $7 \mathrm{G}$.

Sicut Graphis chrysocarpa sed apotheciis pigmento flavo instructis et hymenio insperso differt. Holotype. COSTA RICA. Puntarenas: Las Tablas Protection Zone, Cedro Ridge, Las Alturas Station (La Amistad Pacífico Conservation Area), Talamanca Ridge, $82^{\circ} 50^{\prime} \mathrm{W}, 8^{\circ} 57^{\prime} \mathrm{N}, 1600 \mathrm{~m}$, montane rain forest zone, pasture with group of trees bordering forest, on bark (lower trunk), 26 Jun 2002, Sipman 47811 a (B, holotype; INB3908618 , isotype).

DESCRIPTION-Thallus corticolous, $2-5 \mathrm{~cm}$ diam., $50-150 \mu \mathrm{m}$ thick, continuous; surface uneven, pale greenish gray; prothallus absent. Thallus in section with cartilaginous upper cortex, irregular algal layer and clusters of crystals. Apothecia lirelliform, flexuose, partly branched, prominent, with lateral to thin complete thalline margin, 3-6 mm long, $0.5-0.8 \mathrm{~mm}$ wide, $0.3-0.5 \mathrm{~mm}$ high; disc concealed; proper margin very thick, labia striate, gray but with thin, pale yellow, $\mathrm{K}+$ yellow to salmon pruina (purple when dried); thalline margin laterally thick, pale gray, apically thin (cortex), gray, mostly covered or replaced by yellow pruina. Excipulum crenulate, completely carbonized, $100-150 \mu \mathrm{m}$ wide, black; laterally covered by corticate algiferous thallus including clusters of crystals in basal parts; hypothecium prosoplectenchymatous, $10-20 \mu \mathrm{m}$ high, colorless to pale yellowish; hymenium 150-200 $\mu \mathrm{m}$ high, colorless, strongly inspersed (paraphyses and asci hardly visible), inspersion rapidly disappearing in $\mathrm{KOH}$ (type B); epithecium indistinct. Paraphyses unbranched; asci clavate, 120-180 × 25$35 \mu \mathrm{m}$. Ascospores 48 per ascus, oblong, muriform with $19-25 \times 1-3$ septa, $80-100 \times 10$ $15 \mu \mathrm{m}, 6-8$ times as long as wide, colorless. Secondary chemistry: unknown anthraquinone. 
REMARKS-Graphis flavoaltamirensis combines features of three, distantly related species: the striate lirellae resemble those of $G$. chrysocarpa, but the yellow pigment is different from the latter species, which also deviates by its noninspersed hymenium. The yellow pigment is apparently identical with that of $G$. firferi, which has entire labia, a noninspersed hymenium, and transversely septate ascospores. The inspersed hymenium of $G$. flavoaltamirensis suggests a close relationship with species in the $G$. cinerea aggregate, in particular $G$. argentata, which has the same type of ascospores. Graphis flavoaltamirensis thus differs from $G$. cinerea in the same way as $G$. firferi from $G$. rhizocola.

ECOLOGY - So far only known from the type collection in the montane rain forest zone.

\section{Graphis flavominiata Moncada \& Lücking, sp. nov. Figure $7 \mathrm{~F}$.}

Sicut Graphis firferi sed ascosporis longioribus apicibus muriformibus differt. Holotype. COSTA RICA. Puntarenas: Las Cruces Biological Station and Wilson Botanical Garden near San Vito, 900-1000 m, montane rain forest zone, planted vegetation and disturbed forest, 16 Oct 2004, Moncada 3009 (INB-4056846, holotype).

Paratypes. COSTA RICA. Puntarenas: Las Cruces Biological Station and Wilson Botanical Garden near San Vito, $900-1000 \mathrm{~m}$, montane rain forest zone, planted vegetation and disturbed forest, 16 Oct 2004, Orozco 14 (F). Same locality, young planted trees in meadow on hilltop, on trunk of Cecropia at margin, 10-19 Oct 2004, Sipman $53361 a$ (в). La Amistad International Park, Altamira Station (La Amistad Pacífico Conservation Area), Sendero Gigantes, Talamanca Ridge, $83^{\circ} 01^{\prime} \mathrm{W}, 9^{\circ} 02^{\prime} \mathrm{N}, 1500-1600 \mathrm{~m}$, montane rain forest zone, secondary vegetation dominated by Cecropia, on bark (lower trunk) of Cecropia, 30 Jun 2002, Sipman 48024a (B, INB-3944352). Las Tablas Protection Zone, Cedro Ridge, Las Alturas Station (La Amistad Pacífico Conservation Area), Talamanca Ridge, $82^{\circ} 50^{\prime} \mathrm{W}, 8^{\circ} 57^{\prime} \mathrm{N}, 1600 \mathrm{~m}$, montane rain forest zone, pasture with group of trees bordering forest, on bark (lower trunk), 26 Jun 2002, Sipman 47813e (B, INB-3908632).

DESCRIPTION-Thallus corticolous, $1-3 \mathrm{~cm}$ diam., $50-150 \mu \mathrm{m}$ thick, continuous; surface uneven, pale greenish gray; prothallus absent. Thallus in section with cartilaginous upper cortex, irregular algal layer and clusters of crystals. Apothecia lirelliform, flexuose, partly branched, prominent, lacking or with thin complete thalline margin, 3-8 mm long, 0.4$0.6 \mathrm{~mm}$ wide, $0.3-0.4 \mathrm{~mm}$ high; disc concealed; proper margin thick, labia entire, gray to black but with thin, pale yellow, $\mathrm{K}+$ yellow to salmon pruina (purple when dried); thalline margin absent or thin. Excipulum entire, completely carbonized, 100-150 $\mu \mathrm{m}$ wide, black; hypothecium prosoplectenchymatous, 10-20 $\mu \mathrm{m}$ high, colorless to pale yellowish; hymenium 170 $250 \mu \mathrm{m}$ high, colorless, clear; epithecium indistinct. Paraphyses unbranched; asci clavate, 150 $180 \times 25-35 \mu \mathrm{m}$. Ascospores $4-8$ per ascus, oblong, terminally muriform with 15-21-transverse and 1-2 longitudinal septa in terminal segments, $100-170 \times 12-15 \mu \mathrm{m}, 7-12$ times as long as wide, colorless. Secondary chemistry: unknown anthraquinone.

REMARKS-This new species is closely related to Graphis firferi and differs only by its slightly longer, terminally muriform ascospores. We have studied quite a number of ascospores in the collections of $G$. firferi and never found longitudinal septa, even if the ascospores are fully mature. Therefore, the separation of these two taxa seems justified.

ECOLOGY-Known from several collections in the montane rain forest zone, all originating from the same area.

Graphis fournierii Lizano \& Lücking, sp. nov. Figure 22D.

Sicut Glyphis substriatula sed apotheciis sine pruina et paraphysibus simplicibus differt. Holotype. COSTA RICA. San José: Universidad de Costa Rica Campus (Cordillera Volcánica Central Conservation Area), Central Valley, San José, $84^{\circ} 03^{\prime} \mathrm{W}, 9^{\circ} 56^{\prime} \mathrm{N}, 1200 \mathrm{~m}$, lower montane moist forest zone, planted trees on campus, on bark (lower trunk), 15 Apr 2003, Lücking 16661 (USJ, holotype; F, isotype).

Paratypes. COSTA RICA. Guanacaste: Barra Honda National Park, Barra Honda Biological Station (Tempisque Conservation Area), Barra Honda Mountains, $85^{\circ} 21^{\prime} \mathrm{W}, 10^{\circ} 10^{\prime} \mathrm{N}, 400$ $500 \mathrm{~m}$, lowland to lower montane moist forest zone, disturbed primary and old-growth secondary forest with calcareous rock outcrops, on bark (lower stem), 22 Mar 2004, Lücking 17550c (F), $17553 h$ (F, INB-4006797), $17556 b$ (CR, F), 17558 e (CR, F, INB-4006810, USJ); on bark (lower trunk), 22 Mar 2004, Lücking 17559b (USJ), Nelsen 3817 c (INB-4056134, WIS). Monte Alto Forest Reserve, Monte Alto Biological Station (Tempisque Conservation Area), Nicoya Peninsula, $85^{\circ} 24^{\prime} \mathrm{W}$, $10^{\circ} 02^{\prime} \mathrm{N}, 450-550 \mathrm{~m}$, lowland to lower montane moist forest zone, disturbed primary and oldgrowth secondary forest, on bark (lower trunk), 21 Mar 2004, Lücking 17511i (INB-4017323). San José: Universidad de Costa Rica Campus (Cordillera Volcánica Central Conservation Area), Central Valley, San José, $84^{\circ} 03^{\prime} \mathrm{W}, 9^{\circ} 56^{\prime} \mathrm{N}$, $1200 \mathrm{~m}$, lower montane moist forest zone, planted trees on campus, on bark (lower trunk), $15 \mathrm{Apr}$ 2003, Lücking 16656 (F). 
DESCRIPTION--Thallus corticolous, $2-5 \mathrm{~cm}$ diam., $30-70 \mu \mathrm{m}$ thick, continuous; surface smooth to uneven, yellowish green to ochraceous yellow; prothallus absent. Thallus in section with cartilaginous upper cortex and irregular algal layer. Apothecia lirelliform, flexuose, partly branched, prominent, lacking or with basal thalline margin, $1-5 \mathrm{~mm}$ long, $0.3-0.4 \mathrm{~mm}$ wide, $0.2-0.3 \mathrm{~mm}$ high; disc concealed; proper margin thick, labia striate, black; thalline margin absent or developed only basally. Excipulum crenulate, more or less completely carbonized, $70-120 \mu \mathrm{m}$ wide, black; basally sometimes covered by corticate thallus; hypothecium prosoplectenchymatous, 5-15 $\mu \mathrm{m}$ high, colorless to pale yellowish; hymenium 90-120 $\mu \mathrm{m}$ high, colorless, clear; epithecium indistinct. Paraphyses unbranched; asci clavate, $80-110 \times 18-25 \mu \mathrm{m}$. Ascospores $4(-8)$ per ascus, ellipsoid, muriform, 50-60 × 10$13 \mu \mathrm{m}, 4-5$ times as long as wide, colorless. Secondary chemistry: no substances detected by TLC.

ETYMOLOGY - Graphis fournieri is dedicated to the late Luis Fournier, outstanding Costa Rican botanist and conservationist (Morales, 2002), who founded the Leonelo Oviedo Forest Reserve on the campus of the University of Costa Rica, now one of the few forest relicts left in the Central Valley (Di Stéfano et al., 1996).

REMARKS-At first glance, we identified this taxon with the common Glyphis substriatula, which also has a greenish thallus and prominent black lirellae with striate labia and very similar ascospores. Because of the greenish thallus and black lirellae, both taxa look more like an Opegrapha than a Graphis. However, Glyphis substriatula always has a dark brown pruina along the slit (completely absent in Graphis fournierii), and its paraphyses are thick-walled and gelatinous and somewhat anastomosing (thin-walled and unbranched in G. fournierii). Among Graphis, no species with striate labia, completely carbonized excipulum, and muriform ascospores seems to come close to $G$. fournierii. Most similar are G. plurispora and $G$. multisulcata, but these have erumpent lirellae with lateral or complete thalline margin. Certainly closely related is G. caribica, but that species has a mostly apically carbonized excipulum and transversely septate ascospores. Otherwise, both are morphologically indistinguishable.

ECOLOGY - The new species seems to be restricted to rather dry habitats; all collections originate from semideciduous or evergreen dry forest. Unfortunately, in spite of the very rich collections attributable to Graphis fournierii (based on thallus morphology and apothecial anatomy), most did not feature ascospores. Very few ascospores were eventually found in the material designated as type, but more collections with mature ascospores are required to assess variation in size and number per ascus.

\section{Graphis furcata Fée. Figure 9A.}

Graphis furcata Fée, Essai Crypt. Écorc.: 40.1824. Holotype. South America, Unknown locality, Humboldt \& Bonpland s.n. (G!).

Graphis albissima Müll. Arg., Bull. Herb. Boissier 3: 319. 1895. Holotype. Australia, Knight 147 (G!).

Graphis foliicola Vain., Cat. Welwitsch Afr. Pl. 2: 440. 1901. Holotype. Africa, Welwitsch 393 (TURVainio 27615!).

DIAGNOSIS - Thallus partly ecorticate, smooth to uneven-farinose, yellowish to bluish whitegray. Lirellae erumpent, partly branched, rather thin and wavy, with lateral thalline margin, 1$3 \mathrm{~mm}$ long, $0.1-0.2 \mathrm{~mm}$ broad; labia entire. Excipulum laterally carbonized. Hymenium clear. Ascospores 6-8 per ascus, transversely 59-septate, $25-35 \times 7-10 \mu \mathrm{m}$, hyaline. Secondary chemistry: no substances detected by TLC.

REMARKS--Graphis furcata was circumscribed by Staiger (2002) to cover collections of tropical Graphis that have the same features as G. scripta (see comments under G. scripta). However, G. furcata differs from G. scripta by its very thin, usually wavy lirellae with the disc always concealed and its often partly ecorticate thallus. Graphis scripta typically has exposed, white pruinose discs, and there are several other tropical species, such as G. submarginata, $G$. crebra, and $G$. chondroplaca, that are more similar to $G$. scripta than $G$. furcata is (see comments under G. chondroplaca and G. scripta). Graphis albissima was accepted by Archer (1999, 2006) but in our opinion is a typical G. furcata, which Archer (1999) did not mention in his discussion of $G$. albissima. In his monograph, Archer (2006) distinguishes the two species by ascospore dimensions (20-35 versus 30-40 $\mu \mathrm{m}$ ), but both fit well into the variation observed in the present material. The type of $G$. foliicola Vain. is very small, bearing just one branched lirella, but fits rather well into the concept of $G$. furcata (a K-test on a thin thallus section was negative).

There are two more species that agree with Graphis furcata in having erumpent lirellae with entire labia and lateral thalline margin, concealed 
disc, laterally carbonized excipulum, clear hymenium, and small, transversely septate ascospores. However, their lirellae are usually broader and straight and short, more or less boat-shaped, and more closely resemble those of $G$. leptocarpa, $G$. librata, and $G$. lineola. One of these is the also widely distributed $G$. palmyrensis Zahlbr., originally described from Palmyra Isl. (USA), which agrees morphologically with the previously mentioned three taxa but lacks lichen substances and has a clear hymenium. It would thus key out as $G$. furcata, but its lirellae are different in shape. The other one is $G$. tenella, which eventually produces striate labia but which often features entire labia as well and then closely resembles G. furcata. A specimen of $G$. tenella that bears only firstgeneration lirellae might be difficult to separate from $G$. furcata with certainty, although its lirellae are usually broader.

Specimens Seen-COSTA RICA. Alajuela: Arenal National Park (Arenal Conservation Area), Heliconias trail, $500-600 \mathrm{~m}, 10^{\circ} 27^{\prime} \mathrm{N}, 84^{\circ} 44^{\prime} \mathrm{W}$, secondary forest, 9 Jan 2004, Chaves 1119 (INB). Colinas de San Pedro de San Ramón, 13 Jan 1934, Brenes 18931 (FH). Guanacaste: Lomas Barbudal Biological Reserve (Tempisque Conservation Area), 100-200 m, $10^{\circ} 27^{\prime} \mathrm{N}, 85^{\circ} 21^{\prime} \mathrm{W}, 1$ Oct 2002, Chaves $70 d$ (INB). Monte Alto Forest Reserve, Monte Alto Biological Station (Tempisque Conservation Area), Nicoya Peninsula, $85^{\circ} 24^{\prime} \mathrm{W}, 10^{\circ} 02^{\prime} \mathrm{N}, 450-550 \mathrm{~m}$, lowland to lower montane moist forest zone, disturbed primary and old-growth secondary forest, on bark (lower trunk), 21 Mar 2004, Lücking $17506 a$ (CR, F, INB). Palo Verde National Park (Tempisque Conservation Area), $0-100 \mathrm{~m}, 10^{\circ} 21^{\prime} \mathrm{N}, 85^{\circ} 21^{\prime} \mathrm{W}, 28$ Mar 2003, López 4316 (INB), 4332 (INB); Palo Verde Station (Tempisque Conservation Area), Río Tempisque Bassin, $85^{\circ} 21^{\prime} \mathrm{W}, 10^{\circ} 21^{\prime} \mathrm{N}, 10 \mathrm{~m}$, lowland to lower montane moist forest zone, secondary forest and open secondary vegetation, on bark (lower trunk), 27 Mar 2003, Lücking 16502e (F, INB). Volcán Tenorio National Park, Alto Masis Section (Arenal-Tilarán Conservation Area), Tilarán Ridge, $85^{\circ} 00^{\prime} \mathrm{W}$, $10^{\circ} 37^{\prime} \mathrm{N}, 950-1000 \mathrm{~m}$, lower montane elfin cloud forest zone, disturbed low elfin forest and secondary vegetation, on bark (lower stem), 17 Mar 2004, Sipman 51945 (B, INB). Heredia: Instituto Nacional de Biodiversidad (INBio) campus (Cordillera Volcánica Central Conservation Area), Central Valley, Santo Domingo, $84^{\circ} 05^{\prime} \mathrm{W}, 9^{\circ} 59^{\prime} \mathrm{N}, 1150 \mathrm{~m}$, lower montane moist forest zone, planted trees and secondary forest on institute campus, on bark (lower stem), 14 Mar 2004, Sipman 51752 (B, INB). Limón: Gandoca-Manzanillo Wildlife Refuge, Manzanillo Section (La Amistad Caribe Conservation Area), Manzanillo, $82^{\circ} 53^{\prime} \mathrm{W}$, $9^{\circ} 38^{\prime} \mathrm{N}$, sea level, lowland coastal moist forest zone, disturbed coastal vegetation with Cocos nucifera, Coccoloba uvifera, on bark (lower trunk), 11 Mar 2004, Lücking 17103d (F). Hitoy Cerere Biological Reserve (La Amistad Caribe Conservation Area), El
Espavel trail, $200-300 \mathrm{~m}, 9^{\circ} 40^{\prime} \mathrm{N}, 83^{\circ} 01^{\prime} \mathrm{W}, 2$ Sep 2003, Chaves 1076 (INB); Hitoy Cerere Biological Station (La Amistad Caribe Conservation Area), Talamanca Ridge, $83^{\circ} 02^{\prime} \mathrm{W}, 9^{\circ} 40^{\prime} \mathrm{N}, 150 \mathrm{~m}$, lowland to lower montane rain forest zone, secondary vegetation and disturbed primary forest along river, on bark (lower trunk), 9 Mar 2004, Lücking 17003 (F, USJ), $17026 b$ (CR, F, USJ). Puntarenas: Carara National Park, Quebrada Bonita Section (Pacífico Central Conservation Area), $84^{\circ} 35^{\prime} \mathrm{W}, 9^{\circ} 47^{\prime} \mathrm{N}, 100 \mathrm{~m}$, lowland moist forest zone, partly disturbed dense primary forest with understory dominated by Erythrochiton gymnanthus, on bark (lower trunk), 18 Jul 2002, Lücking $15615 \mathrm{c}$ (F, INB), Sipman 48382c (B, INB). Isla del Caño Biological Reserve (Osa Conservation Area), 0-100 m, 8 $42^{\prime} \mathrm{N}, 83^{\circ} 52^{\prime} \mathrm{W}, 27$ Aug 2003, Navarro 7137 (INB). Las Tablas Protection Zone, Los Portones Section (La Amistad Pacífico Conservation Area), Talamanca Ridge, $82^{\circ} 48^{\prime} \mathrm{W}, 8^{\circ} 55^{\prime} \mathrm{N}, 1600 \mathrm{~m}$, montane rain forest zone, abandoned roadside pasture with dense shrubs and treelets, on bark (lower stem), 28 Jun 2002, Lücking 15167c (F, INB). Mellizas, border to Panama (La Amistad Pacífico Conservation Area), 1400-1500 m, 8 $53^{\prime} \mathrm{N}, 82^{\circ} 46^{\prime} \mathrm{W}, 28$ Aug 2002, Navarro $5282 f$ (INB); Finca Santa Marta, foot of Cerro Quijada del Diablo (La Amistad Pacífico Conservation Area), $1600-1700 \mathrm{~m}, 8^{\circ} 53^{\prime} \mathrm{N}, 82^{\circ} 45^{\prime} \mathrm{W}, 30$ Aug 2002, Chaves $28 a($ INB).

\section{Graphis geraensis Redinger. Figure 12D.}

Graphis geraensis Redinger, Ark. Bot. 27A(3): 12. 1935. Holotype. Brazil, Malme 320 (s 6503!).

DiAGNOSIS - Thallus corticate, smooth to uneven, white-gray. Lirellae prominent, rarely branched, lacking thalline margin, jet-black, Opegrapha-like, 1-2 $\mathrm{mm}$ long, $0.1-0.2 \mathrm{~mm}$ broad; labia entire. Excipulum completely carbonized. Hymenium clear. Ascospores 4-8 per ascus, transversely 5-9-septate, $20-40 \times 5-7 \mu \mathrm{m}$, hyaline. Secondary chemistry: no substances detected by TLC.

REMARKS-Graphis geraensis is close to $G$. virescens, but the latter has sessile lirellae and slightly larger ascospores. Graphis geraensis provides a transition between the G. nuda group and certain species in the G. scripta and $G$. oxyclada groups.

Specimens SEen-COSTA RICA. Alajuela: Colinas de San Pedro de San Ramón, 13 Jan 1934, Brenes 18930 (FH). Limón: Waldeck Farm, jungle, 6 Apr 1930 , Dodge \& Nevermann s.n. (FH). Puntarenas: Las Cruces Biological Station and Wilson Botanical Garden near San Vito, $900-1000 \mathrm{~m}$, montane rain forest zone, planted vegetation and disturbed forest, 10-24 Oct 2004, Lücking 18056 (F), Sipman 53344 a (B).

Graphis glaucescens Fée. Figure 8A.

Graphis glaucescens Fée, Essai Crypt. Écorc.: 36. 1824. Lectotype (fide Wirth \& Hale, 1978: 15). 
South America, Humboldt \& Bonpland s.n. (G; s 2184, isolectotype!).

Graphis caesia Müll. Arg., Linnaea 43: 37. 1880 [nom. illeg., ICBN Art. 53.1; non Graphis caesia Spreng.]; Graphis angolensis C. W. Dodge, Nova Hedwigia Beih. 12: 48.1964 [nom. nov.]. Holotype. Angola, Pechuel-Loesche s.n. (B, not seen).

Graphis glaucocaesia Müll. Arg., Rev. Mycol. 10:

118. 1888. Holotype. Paraguay, Balansa s.n. (G!).

Graphis bulacana Vain., Ann. Acad. Sci. Fenn., Ser.

A, 15(6): 256. 1921. Holotype. Philippines,

Merrill 7051 (TUR-Vainio 27882!).

Graphis caesioglauca Redinger, Ark. Bot. 27A(3): 53. 1935. Holotype. Paraguay, Malme 1526 (S 3947 !; s 3948 , isotype!).

DiAGNOSIS-Thallus ecorticate, farinose, bluish white-gray. Lirellae erumpent, partly branched, with lateral thalline margin, $1-5 \mathrm{~mm}$ long, $0.2-0.3 \mathrm{~mm}$ broad; labia entire (to striate), white pruinose. Excipulum apically carbonized. Hymenium clear. Ascospores 8 per ascus, transversely 7-11-septate, $25-45 \times 6-10 \mu \mathrm{m}$, hyaline. Secondary chemistry: no substances detected by TLC.

REMARKS-Graphis glaucescens is one of the relatively well-documented examples where the separation of species with entire versus striate lirellae is untenable. The species was mentioned as a possibly earlier name for $G$. bulacana by Staiger (2002). Examination of the type of $G$. glaucescens revealed that its labia are mostly striate, while those of the type of $G$. bulacana are mostly entire and only partly striate as indicated by Staiger (2002: Abb. 61). Otherwise, the two forms are absolutely identical. We first intended to keep the two taxa separate, but study of a large amount of material from Costa Rica, the West Indies (Lücking et al., 2008b) and northeastern Brazil (Cáceres, 2007) showed that very often the labia are entire but with a few striate labia in the thallus center. More rarely, most of the labia are striate but then entire at the thallus margin (as in the type of G. caesioglauca). Thalli with completely entire labia are most common. Based on these observations, it seems arbitrary to separate two taxa on the basis of labia morphology (see also comments under $G$. argentata). Graphis caesia Müll. Arg. and $G$. glaucocaesia Müll. Arg. (two syntypes from Paraguay and also reported from Costa Rica; Müller Argoviensis, 1893a) also represent very typical $G$. glaucescens with mostly entire labia, as does the material identified as $G$. angolensis by Dodge (1964).

Graphis glaucescens is superficially similar to G. caesiella and $G$. dendrogramma, but the latter two are well separated by their corticate thalli, laterally carbonized excipulum, and chemistry (norstictic and stictic acid, respectively). Graphis glaucescens might also be confused with species of the genus Diorygma (Kalb et al., 2004) but can be distinguished from these by the absence of lichen substances, among other features.

SPeCimens Seen_COSTA RICA. Alajuela: Huetar Norte, Boca Tapada, Refugio Nacional de Vida Silvestre Mixto Maquenque, $0-100 \mathrm{~m}, 10^{\circ} 42^{\prime} \mathrm{N}$, $84^{\circ} 11^{\prime} \mathrm{W}, 8$ May 2005, Chaves 2305 (INB). Heredia: La Selva Protection Zone, La Selva Biological Station (Cordillera Volcánica Central Conservation Area), Volcánica Central Ridge, $84^{\circ} 03^{\prime} \mathrm{W}, 10^{\circ} 26^{\prime} \mathrm{N}, 50 \mathrm{~m}$, lowland rain forest zone, disturbed primary and secondary forest, on bark (lower trunk), 27 Oct 2002, Lücking 16044 (F). Limón: Gandoca-Manzanillo Wildlife Refuge, Manzanillo Section (La Amistad Caribe Conservation Area), Manzanillo, $82^{\circ} 53^{\prime} \mathrm{W}, 9^{\circ} 38^{\prime} \mathrm{N}$, sea level, lowland coastal moist forest zone, disturbed coastal vegetation with Cocos nucifera, Coccoloba uvifera, on bark (lower stem), 11 Mar 2004, Lücking 17106e (F). Hitoy Cerere Biological Reserve (La Amistad Caribe Conservation Area), El Espavel trail, 200-300 m, $9^{\circ} 40^{\prime} \mathrm{N}, 83^{\circ} 01^{\prime} \mathrm{W}, 2$ Sep 2003, Chaves 1075 (INB); Hitoy Cerere Biological Station (La Amistad Caribe Conservation Area), Talamanca Ridge, $83^{\circ} 02^{\prime} \mathrm{W}, 9^{\circ} 40^{\prime} \mathrm{N}, 150 \mathrm{~m}$, lowland to lower montane rain forest zone, planted trees and secondary vegetation, on bark (lower trunk), 9 Mar 2004, Sipman 51605 (B, INB); on bark (lower stem), 9 Mar 2004, Lücking $17010 a(\mathrm{CR}, \mathrm{F})$; secondary vegetation and disturbed primary forest along river, on bark (lower trunk), 9 Mar 2004, Aptroot 60114 (ABL, INB), Lücking $17000 g$ (F); 100-150 m, lowland to lower montane rain forest zone, exposed trees and fence posts along pasture, on wood (fence post), 10 Mar 2004, Aptroot 60270 (ABL, INB). Puntarenas: Carara National Park, Quebrada Bonita Section (Pacífico Central Conservation Area), $84^{\circ} 35^{\prime} \mathrm{W}, 9^{\circ} 47^{\prime} \mathrm{N}, 100 \mathrm{~m}$, lowland moist forest zone, partly disturbed dense primary forest with understory dominated by Erythrochiton gymnanthus, on bark (lower trunk), 18 Jul 2002, Sipman 48384 (B, INB), 48386 c (B, INB). Corcovado National Park, Sirena Section, Sirena Biological Station (Osa Conservation Area), Osa Peninsula, $83^{\circ} 35^{\prime} \mathrm{W}, 8^{\circ} 29^{\prime} \mathrm{N}$, sea level, lowland and coastal rain forest zone, old-growth coastal secondary forest and primary forest remnants on sandy soil, on bark (lower trunk), 7 Apr 2003, Lücking 16250 b (F), Buck 44109 (INB, NY). Isla del Coco National Park, Valle de Los Piratas, 0-100 m, $5^{\circ} 32^{\prime} \mathrm{N}$, $87^{\circ} 03^{\prime} \mathrm{W}, 3$ Jul 2005, Fletes 7851 (INB). Manuel Antonio National Park, near Quepos, $84^{\circ} 09^{\prime} \mathrm{W}, 9^{\circ} 23^{\prime} \mathrm{N}$, sea level, scattered trees around hotel at end station of bus line, 23 Nov 1988, Sipman 42290 (B, CR).

Graphis gomezii Lücking, Will-Wolf \& Umaña, sp. nov. Figure 22C.

Sicut Graphis polillensis sed lirellis maioribus et ascosporis minoribus differt. Holotype. COSTA RICA. Alajuela: Volcán Tenorio National Park, Pilón Biological Station (Arenal-Tempisque Con- 
servation Area), Tilarán Ridge, $84^{\circ} 59^{\prime} \mathrm{W}$, $10^{\circ} 43^{\prime} \mathrm{N}, 700-900 \mathrm{~m}$, lower montane cloud forest zone, partly disturbed primary forest, on bark (upper trunk, fallen), 16 Mar 2004, Will-Wolf $12740 a$ (CR, holotype; F, INB-4051171, USJ, WIS, isotypes).

Paratypes. COSTA RICA. Guanacaste: Volcán Tenorio National Park, Alto Masis Section (Arenal-Tilarán Conservation Area), Tilarán Ridge, $85^{\circ} 00^{\prime} \mathrm{W}, 10^{\circ} 37^{\prime} \mathrm{N}, 950-1000 \mathrm{~m}$, lower montane elfin cloud forest zone, disturbed low elfin forest and secondary vegetation, on bark (lower stem), 17 Mar 2004, Lücking 17320 (F, INB4005471); on bark (lower trunk), 17 Mar 2004, Lücking 17321g (F), 17324a (F, INB-4005478); Aptroot 60615 (ABL, INB-3968030).

DESCRIPTION-Thallus corticolous, $3-10 \mathrm{~cm}$ diam., 50-100 $\mu \mathrm{m}$ thick, continuous; surface uneven, white to pale greenish gray; prothallus absent. Thallus in section with thick cartilaginous upper cortex, irregular algal layer and clusters of crystals. Apothecia lirelliform, flexuose, irregularly to radiately branched, erumpent, with lateral thalline margin, 5-30(-80!) $\mathrm{mm}$ long, $0.4-0.6 \mathrm{~mm}$ wide, $0.2-0.3 \mathrm{~mm}$ high; disc concealed; proper margin thick, labia entire, black; thalline margin laterally thick, white. Excipulum entire, completely carbonized, 50-150 $\mu \mathrm{m}$ wide, black, basal internal parts brown; laterally covered by corticate algiferous thallus including clusters of crystals; hypothecium prosoplectenchymatous, 10-20 $\mu \mathrm{m}$ high, colorless to pale yellowish; hymenium 150-200 $\mu \mathrm{m}$ high, colorless, clear; epithecium granulose, 5-15 $\mu \mathrm{m}$ high, olive brown. Paraphyses unbranched; asci fusiform, 140-180 $\times$ 30-40 $\mu \mathrm{m}$. Ascospores 4-8 per ascus, ellipsoid, muriform, 35-50 × 15-20 $\mu \mathrm{m}, 2-3$ times as long as wide, colorless. Secondary chemistry: no substances detected by TLC.

ETYMOLOGY-This new species is dedicated to Luis Diego Gómez, esteemed colleague, mentor, and friend, and one of the most outstanding botanists and naturalists of Costa Rica and Latin America.

REMARKS-The Costa Rican material all originates from the same area at Volcán Tenorio, a very wet lower montane rain forest with the characteristics of an elfin forest. The material is characterized by erumpent, very conspicuous lirellae with jet-black labia, completely carbonized excipulum and medium-sized, muriform ascospores. To our knowledge, the lirellae of Graphis gomezii, in one specimen reaching $80 \mathrm{~mm}$, are the longest reported in the genus Graphis so far and perhaps the longest in any Graphidaceae.
Among the many type specimens studied, two previously described taxa come closest: Graphis dolichographa Nyl. from Colombia, which has immersed lirellae with a thick complete thalline margin and larger ascospores (40-90 × 16$28 \mu \mathrm{m})$, and $G$. polillensis Vain. from the Philippines, which has slightly smaller, erumpent and jet-black lirellae and presumedly 1 -spored asci with ascospores $40-70 \times 15-30 \mu \mathrm{m}$. The general aspect of these species and $G$. gomezii places them in the $G$. insulana group, although the other species in that group have an apically or laterally carbonized excipulum.

Graphis gomezii can be confused with two other species that were found at the same localities and also have large, erumpent lirellae with jet-black labia, that is, G. myrtacea and $G$. tenoriensis. However, both have striate labia with conspicuous white lines between the striae, mostly single-spored asci and larger ascospores $(70-170 \times 20-40 \mu \mathrm{m})$, and $G$. tenoriensis also differs in its excipulum being apically carbonized only.

ECOLOGY-Known from a few collections in a rather restricted area in the lower montane cloud forest zone of northwestern Costa Rica; found in rather exposed situations.

\section{Graphis gracilis (Fr.) Leight. Figure $21 \mathrm{G}$.}

Graphis gracilis (Fr.) Leight., Trans. Linn. Soc. London 27: 174. 1869; Opegraplia gracilis Fr., Kongl. Vetensk. Akad. Nya Handl. 1820: 44. 1820; Graphina gracilis (Fr.) Müll. Arg., Mém. Soc. Phys. Hist. Nat. Genève 39(8): 39. 1887. Holotype. Unknown locality, s.col. (UPS!).

Graphis analoga Nyl., Ann. Sci. Nat. Bot., Ser. 4, 11: 244. 1859; Graphina analoga (Nyl.) Zahlbr., Denkschr. Math.-Naturw. Klasse K. Akad. Wiss. Wien 83: 107. 1909. Holotype. Tahiti, Viellard \& Planchet G13:8 (H-Nyl 7432!).

Graphina renschiana Müll. Arg., Flora 68: 512. 1885. Holotype. Madagascar, Rensch 969 (G!).

Graphis antillarum var. manilensis Vain., Ann. Acad. Sci. Fenn., Ser. A, 15(6): 205. 1921. Holotype. Philippines, Rosenbluth \& Tamesis 13753 (TURVainio 27185!).

Graphina symplocorum Zahlbr. in Handel-Mazzetti, Symb. Sin. 3: 55. 1930. Isotype. China, HandelMazzetti 11459 (s 3963!).

Diagnosis - Thallus corticate, smooth to uneven, yellowish gray. Lirellae erumpent, richly branched, with basal thalline margin, 1-7 mm long, $0.1-0.2 \mathrm{~mm}$ broad; labia entire. Excipulum laterally (to thinly completely) carbonized. Hymenium clear. Ascospores 6-8 per ascus, muriform, 20-30 $\times$ 8-12 $\mu \mathrm{m}$, hyaline. Secondary chemistry: norstictic acid. 
REMARKS-For a long time, we identified this taxon with the name Graphis analoga Nyl., until we came across the earlier name $G$. gracilis, based on annotations made on Hale's index cards. In the Checklist of Japanese Lichens (Kurokawa, 2003), Graphina symplocorum is given as synonym of Graphis deserpens Vain., while we list it as synonym of $G$. gracilis. Graphis deserpens and $G$. gracilis are morphologically and anatomically very similar and differ chiefly in their chemistry, that is, stictic versus norstictic acid. A microscopic K-test on a section of an isotype of Graphina symplocorum [China, Handel-Mazetti s.n. (s 3963)] produced a very typical norstictic reaction (red needles), and Zahlbruckner (1930) also describes the K-reaction of the thallus as "fulvus," which would be indicative of norstictic acid. Hence, Graphina symplocorum has to be considered a synonym of Graphis gracilis.

SPeCimens SeEN-COSTA RICA. Guanacaste: Quebrada Azul, Tilarán (Arenal Conservation Area), $700-800 \mathrm{~m}, 10^{\circ} 31^{\prime} \mathrm{N}, 84^{\circ} 59^{\prime} \mathrm{W}, 1$ Mar 2003, Chaves 425 (INB). Volcán Tenorio National Park, Alto Masis Section (Arenal-Tilarán Conservation Area), Tilarán Ridge, $85^{\circ} 00^{\prime} \mathrm{W}, 10^{\circ} 37^{\prime} \mathrm{N}, 950-1000 \mathrm{~m}$, lower montane elfin cloud forest zone, disturbed low elfin forest and secondary vegetation, on bark (lower stem), 17 Mar 2004, Sipman 51916 (B, INB); Aptroot 60612 (ABL, INB). Heredia: La Selva Protection Zone, La Selva Biological Station (Cordillera Volcánica Central Conservation Area), $50-100 \mathrm{~m}, 10^{\circ} 25^{\prime} \mathrm{N}, 84^{\circ} 00^{\prime} \mathrm{W}$, Jan 1997, Lücking 97-22 (F). Puntarenas: Las Cruces Biological Station and Wilson Botanical Garden near San Vito, 900-1000 m, montane rain forest zone, planted vegetation and disturbed forest, Feb 2000, Lücking 00-14 (F); 16 Oct 2004, Esquivel \& Cifuentes RE 10b/MC 34lb (INB), RE lalMC 351 a (INB), Paredes et al. 1069 (INB).

Graphis granulosa (Müll. Arg.) Lücking, comb. nov. Figure $25 \mathrm{~A}-\mathrm{B}$.

Graphina granulosa Müll. Arg., Flora 69: 314. 1886. Holotype. Jamaica, Hart s.n. (G!).

Diagnosis-Thallus corticate, verruculose, yellow-gray. Lirellae prominent, unbranched, with thin complete, verruculose thalline cover, 1-2 mm long, 0.3-0.4 mm broad; labia (entire to) striate. Excipulum completely carbonized. Hymenium clear. Ascospores single, muriform, 80-140 $\times 25-35 \mu \mathrm{m}$, hyaline. Secondary chemistry: hypostictic and hypoconstictic acids.

REMARKS-This conspicuous taxon belongs in the Graphis acharii group and is easily recognized by its verruculose thallus and thalline-covered lirellae, in combination with hypo- stictic and hypoconstictic acids as secondary compounds. The Costa Rican material mostly bears entire lirellae, but the remaining characters leave no doubt that it deals with Graphis granulosa.

Breuss (2004) reports Graphina rugulosa (Fée) Müll. Arg. from Costa Rica. The application of this name is ambiguous. According to Müller Argoviensis (1887) and Hale's card index, the supposed type material in $G$ on which Müller Argoviensis (1887) based his combination into Graphina has muriform ascospores and morphologically resembles a species of the $G$. dussii aggregate (short lirellae with thick lateral thalline margin), similar to or identical with G. plagiocarpa. However, an authentic isotype found in $\mathrm{L}$ has transversely septate, very large ascospores (up to $200 \mu \mathrm{m}$ long) and short to rather elongate lirellae with thin complete thalline cover; it is identical with $G$. tumidula. We have not seen the material cited by Breuss (2004) and are unable to assess its taxonomic status, but the name Graphina rugulosa has to be deleted from the list of species reported from Costa Rica.

Specimens SeEn--COSTA RICA. Alajuela: Alto del Mondongo del San Ramón, 800 m, 9 Jan 1930, Brenes 298 (FH).

Graphis gregmuelleri Sipman \& Lücking, sp. nov. Figure $13 \mathrm{H}$.

Sicut Graphis immersoides sed ascosporis transversaliter septatis differt. Holotype. Costa Rica, Alajuela: Volcán Tenorio National Park, Pilón Biological Station (Arenal-Tempisque Conservation Area), Tilarán Ridge, $84^{\circ} 59^{\prime} \mathrm{W}, 10^{\circ} 43^{\prime} \mathrm{N}, 700 \mathrm{~m}$, lower montane cloud forest zone; grazed, abandoned Syzyginm jambos plantation surrounded by Gmelina arborea trees and pasture fields, 15 Mar 2004, Sipman 51764 (INB, holotype; B, isotype).

Paratypes. Costa Rica, Alajuela: Volcán Tenorio National Park, Pilón Biological Station (ArenalTempisque Conservation Area). Tilarán Ridge, $84^{\circ} 59^{\prime} \mathrm{W}, 10^{\circ} 43^{\prime} \mathrm{N}, 700 \mathrm{~m}$, lower montane cloud forest zone; grazed, abandoned $S_{y=y}$ gium jambos plantation surrounded by Gmelina arborea trees and pasture fields, 15 Mar 2004, Sipman 51803 (B, INB), 51786 (B, INB); partly disturbed primary forest, on bark (branch, fallen), 16 Mar 2004 , Sipman 51914 (B, INB).

DESCRIPTION-Thallus corticolous, $2-10 \mathrm{~cm}$ diam., 30-70 $\mu \mathrm{m}$ thick, continuous; surface smooth to uneven, pale gray; prothallus absent. Thallus in section with cartilaginous upper cortex, irregular algal layer and clusters of crystals. Apothecia lirelliform, straight to flexuose, radiately branched, erumpent, with apical- 
ly thin, complete thalline margin, 2-6 mm long, $0.2-0.3 \mathrm{~mm}$ wide, $0.1-0.2 \mathrm{~mm}$ high; disc concealed; labia eventually striate, black; thalline margin well developed, concolorous with thallus. Excipulum entire, apically and basally carbonized, $30-50 \mu \mathrm{m}$ wide, black, lateral parts brownish yellow; covered by corticate algiferous thallus including clusters of crystals; hymenium 90$140 \mu \mathrm{m}$ high, colorless, clear. Ascospores 2-8 per ascus, oblong to ellipsoid, 11-17-septate, 45$80 \times 10-12 \mu \mathrm{m}, 4-6$ times as long as wide, colorless. Secondary chemistry: no substances detected by TLC.

ETYMOLOGY - This new species is dedicated to our esteemed colleague, Greg Mueller, for his contributions to INBio and to mycology in Costa Rica and Latin America as a whole.

REMARKS-This species belongs in a group of taxa with the carbonization of the excipulum restricted to the apical and basal parts of the excipulum, a very rare feature in the family. Graphina immersa Müll. Arg. and the newly described Graphis mirabilis exhibit the same type of excipulum but differ in their either submuriform ascospores and completely immersed lirellae ( $G$. immersa) or muriform ascospores and inspersed hymenium ( $G$. mirabilis).

Unfortunately, Graphina immersa cannot be recombined in Graphis since the name $G$. immersa Fink already exists. We therefore propose a replacement name: Graphis immersoides Lücking, nom. nov. [Bas.: Graphina immersa Müll. Arg., Rev. Mycol. 10: 120. 1888. Holotype. Paraguay, Balansa s.n. (G!; Balansa, Lich. Paraguayenses 184)].

ECOLOGY-Found in the lower montane cloud forest zone in northeastern Costa Rica in rather exposed situations.

\section{Graphis haleana R. C. Harris. Figure 10B.}

Graphis haleana R. C. Harris, Some Florida Lichens: 20. 1990. Holotype. U.S.A. (Florida), Harris 25248 (NY!).

Graphis cuiabensis Staiger, Biblioth. Lichenol. 85: 226. 2002 [nom. inval., ICBN Art. 32, 35-37]. Original material: Brazil, Kalb 28244 (hb. Kalb!).

DiagNosis-Thallus corticate, smooth to uneven, white, UV+ yellow. Lirellae prominent, rarely branched, lacking thalline margin, 1$5 \mathrm{~mm}$ long, $0.2-0.3 \mathrm{~mm}$ broad; labia striate. Excipulum laterally carbonized. Hymenium clear. Ascospores 8 per ascus, transversely 913-septate, $50-75 \times 9-12 \mu \mathrm{m}$, hyaline. Secondary chemistry: lichexanthone.
REMARKS - Staiger (2002) separated her provisionally described Graphis cuiabensis from $G$. haleana by the more flexuose lirellae and slightly larger ascospores with more numerous septa $(70$ $85 \times 10-13 \mu \mathrm{m}$ with $13-19$ septa versus $50-75 \times$ 9-12 $\mu \mathrm{m}$ with 9-13 septa). The well-developed material collected in Costa Rica has slightly branched, straight to slightly flexuose lirellae and 9-17-septate, 50-80 × 9-12 $\mu \mathrm{m}$ large ascospores, and strongly suggests that the two taxa are conspecific. The similar $G$. lucifica has 5-9septate ascospores being $20-40 \times 7-10 \mu \mathrm{m}$ in size. Both seem to be the only representatives of the $G$. duplicata group with lichexanthone, and each has a chemically "empty" chemomorph: $G$. haleana versus $G$. striatula (slightly shorter ascospores) and $G$. lucifica versus $G$. duplicata.

SPECIMENS SEeN-COSTA RICA. Guanacaste: Tropica Verde Reforestation Project (Tempisque Conservation Area), Nicoya Peninsula, $85^{\circ} 23^{\prime} \mathrm{W}, 10^{\circ} 01^{\prime} \mathrm{N}$, $850-900 \mathrm{~m}$, lowland to lower montane moist forest zone, exposed trees and fence posts along pasture, on bark (lower trunk), 22 Mar 2004, Lücking 17620 (CR, F, INB, USJ), Sipman 52085 (B, INB). Puntarenas: Mellizas, border to Panama (La Amistad Pacífico Conservation Area), $1400-1500 \mathrm{~m}, 8^{\circ} 53^{\prime} \mathrm{N}, 82^{\circ} 46^{\prime} \mathrm{W}$, 28 Aug 2002, Navarro 5278e (INB).

\section{Graphis hyphosa Staiger. Figure 13A.}

Graphis intricata f. meizospora Redinger, Ark. Bot. 27A(3): 20. 1935. Lectotype (here selected!). Paraguay, Malme 1913 (s 6499!). Syntype. Brazil, Malme 2357 (s 6498!).

DiAGNOSIS - Thallus partly ecorticate, smooth to uneven-farinose, yellowish white-gray. Lirellae immersed-erumpent, stellately branched and appearing pseudostromatic, with lateral thalline margin, $1-5 \mathrm{~mm}$ long, $0.1-0.2 \mathrm{~mm}$ broad; labia entire. Excipulum completely carbonized. Hymenium clear. Ascospores 8 per ascus, transversely 5-9-septate, 20-35 × 6-9 $\mu \mathrm{m}$, hyaline. Secondary chemistry: no substances detected by TLC.

REMARKS - One of the few new species described by Staiger (2002) in the genus Graphis, based on material from Brazil but also reported from Costa Rica in the protologue; not found in the present collections. The species most similar are Graphis litoralis (norstictic, salazinic, and protocetraric acids, lirellae not pseudostromatic), G. caesiocarpa (norstictic acid, lirellae not pseudostromatic), and $G$. sitiana (ascospores smaller with less septa, lirellae prominent, not pseudostromatic). Graphis intricata f. meizospora is conspecific but does not have priority outside its rank; the 
two syntypes in S are identical, and the larger specimen from Paraguay was selected as lectotype.

Graphis hypocrellina Lücking \& Chaves, sp. nov. Figure $7 \mathrm{H}$.

Sicut Graphis striatula sed excipulo isohypocrellina continente differt. Holotype. COSTA RICA. Puntarenas: La Amistad International Park, Cerro Biolley Section, Sabanas Esperanza (La Amistad Pacífico Conservation Area), Terraba Valley, $83^{\circ} 03^{\prime} \mathrm{W}, 9^{\circ} 04^{\prime} \mathrm{N}, 1300-1400 \mathrm{~m}$, lowland to lower montane moist forest savanna zone, disturbed savanna vegetation with abundant shrubs and trees, on bark (lower stem), $2 \mathrm{Jul}$ 2002, Lücking 15297d (F, holotype).

Paratypes. COSTA RICA. Guanacaste: Novasa Wind Power Project (Arenal-Tilarán Conservation Area), Tilarán Ridge, Tierras Morenas, $85^{\circ} 01^{\prime} \mathrm{W}, 10^{\circ} 38^{\prime} \mathrm{N}, 750 \mathrm{~m}$, lower montane moist forest zone, exposed trees and fence posts along pasture, on wood (pole), 23 Mar 2004, Sipman 52102 (B, INB-4054043). Puntarenas: La Amistad International Park, Cerro Biolley Section, Sabanas Esperanza (La Amistad Pacífico Conservation Area), Terraba Valley, $83^{\circ} 03^{\prime} \mathrm{W}, 9^{\circ} 04^{\prime} \mathrm{N}$, 1300-1400 m, lowland to lower montane moist forest savanna zone, disturbed savanna vegetation with abundant shrubs and trees, on bark (lower trunk), 2 Jul 2002, Sipman 48122 (B, INB3946195). Las Cruces Biological Station and Wilson Botanical Garden near San Vito, 900$1000 \mathrm{~m}$, montane rain forest zone, planted vegetation and disturbed forest, 10-24 Oct 2004, Sipman 53291 (B, INB-3993696), 53382 (B). Las Tablas Protection Zone, Los Portones Section (La Amistad Pacífico Conservation Area), Talamanca Ridge, $82^{\circ} 48^{\prime} \mathrm{W}, 8^{\circ} 55^{\prime} \mathrm{N}, 1600 \mathrm{~m}$, montane rain forest zone, abandoned roadside pasture with dense shrubs and treelets, on bark (lower trunk), 28 Jun 2002, Sipman 47949e (B, INB-3924222).

DESCRIPTION--Thallus corticolous, $2-7 \mathrm{~cm}$ diam., $50-100 \mu \mathrm{m}$ thick, continuous; surface uneven to weakly verrucose, pale gray to white; prothallus absent. Thallus in section with cartilaginous upper cortex, irregular algal layer and clusters of crystals. Apothecia lirelliform, flexuose, partly branched, prominent, lacking thalline margin, $1-8 \mathrm{~mm}$ long, $0.2-0.5 \mathrm{~mm}$ wide, 0.3-0.4 mm high; disc concealed; proper margin very thick, labia striate, black. Excipulum crenulate, laterally (to completely) carbonized, 50-150 $\mu \mathrm{m}$ wide, black, suffused with dark red, $\mathrm{K}+$ green pigment (isohypocrellin); hypothecium prosoplectenchymatous, 5-10 $\mu \mathrm{m}$ high, reddish, $\mathrm{K}+$ green; hymenium 70-130 $\mu \mathrm{m}$ high, colorless, clear; epithecium indistinct. Paraphyses unbranched; asci ellipsoid, 70-110 × 30$50 \mu \mathrm{m}$. Ascospores 8 per ascus, ellipsoid to fusiform with rounded ends, transversely 9-13septate, $40-60 \times 8-13 \mu \mathrm{m}, 4-5$ times as long as wide, colorless. Secondary chemistry: isohypocrellin.

REMARKS-Isohypocrellin is the most common pigment found in Graphidaceae and occurs as epithecial pigment in species of Phaeographis, Thalloloma, and Thecaria (Staiger 2002). Yet this is only the second report in the genus Graphis, and in spite of an extensive literature search and type studies, we have not found a name for this taxon. Also, the abundant occurrence of the pigment within and below the otherwise carbonized, black excipulum and not as pruina on top of it is unusual. Graphis hypocrellina is otherwise similar to G. striatula and a typical representative of the $G$. duplicata group.

A second Graphis species with isohypocrellin appears to be G. persicina G. Mey. \& Flot. Vainio (1921) described the hymenium as "guttulis resinosis ... purpureum croceumve ... KOH sordide virescentibus," and we were able to confirm the presence of isohypocrellin-containing, $\mathrm{K}+$ green droplets in the hymenium of specimens from the Philippines, Papua New Guinea, and Hong Kong. The species differs from $G$. hypocrellina because the pigment is in oily droplets in the hymenium (as in Thecaria montagnei) and not in the excipulum and substrate. It apparently has a palaeotropical distribution.

The available material of Graphis hypocrellina can be divided into two forms: the typical form with basally more or less open excipulum and an atypical form with basally closed and very thick, completely carbonized excipulum. We did not find ascospores in the material of the second form, and we have united both under a single name here because of their identical morphology and presence of isohypocrellin in the excipulum. The development and carbonization of the basal excipulum can vary within species of the $G$. duplicata group, such as $G$. longula and $G$. rimulosa, and the example of this new species indicates that this infraspecific variation is perhaps greater than previously assumed.

ECOLOGY - Apparently with a broad ecological amplitude, although most of the collections are from rather dry and/or exposed situations.

Graphis illinata Eschw. Figure 23F.

Graphis illinata Eschw. in Martius. Fl. Bras. 1: 82. 1833; Graphina illinata (Eschw.) M. Wirth \& Hale, Smiths. Contr. Bot. 40: 37. 1978. Lectotype (fide Wirth \& Hale, 1978: 37). Brazil, Martius s.n. (M, not seen).

DiAGNOSIS-Thallus corticate, smooth to uneven, white-gray. Lirellae prominent, partly 
branched, with complete thalline cover, 1-7 mm long, 0.4-0.6 mm broad; labia entire. Excipulum completely carbonized. Hymenium clear. Ascospores single, muriform, $100-150 \times 18-30 \mu \mathrm{m}$, hyaline. Secondary chemistry: no substances detected by TLC.

REMARKS-Staiger (2002) discussed Graphis illinata under G. muscicola (now G. mexicana). Both species have a very similar ascoma anatomy but are clearly distinguished by their lirellae morphology (strongly elongate in G. illinata versus round and perithecioid in G. mexicana). Graphis illinata resembles G. rhizocola but is distinguished by its muriform ascospores; also, its thallus is usually white-gray and never greenish gray. Graphis carassensis is also similar, but that species has more robust lirellae that lack the crystals in the thalline cover found in many other species, including G. illinata.

Graphis illinata was listed for Cocos Island by Elix \& McCarthy (1998). Material of this species housed at $\mathrm{FH}$ was misidentified as Graphina heteroplaca Müll. Arg.

SPECIMENS SEen-COSTA RICA. Alajuela: San Ramón, Feb 1931, Brenes 14473 (FH). Volcán Tenorio National Park, Pilón Biological Station (ArenalTempisque Conservation Area), Tilarán Ridge, $84^{\circ} 59^{\prime} \mathrm{W}, 10^{\circ} 43^{\prime} \mathrm{N}, 700 \mathrm{~m}$, lower montane cloud forest zone, exposed trees and fence posts along pasture, on bark (log, rotten, wet), 16 Mar 2004, Lücking 17252 s (F). Guanacaste: Volcán Tenorio National Park, Alto Masis Section (Arenal-Tilarán Conservation Area), Tilarán Ridge, $85^{\circ} 00^{\prime} \mathrm{W}, 10^{\circ} 37^{\prime} \mathrm{N}, 950-1000 \mathrm{~m}$, lower montane elfin cloud forest zone, disturbed low elfin forest and secondary vegetation, on bark (lower stem), 17 Mar 2004, Aptroot 60619 (ABL, INB), Sipman 51921 (B. INB). Puntarenas: La Amistad International Park. Altamira Station (La Amistad Pacífico Conservation Area), Talamanca Ridge, $83^{\circ} 00^{\prime} \mathrm{W}, 9^{\circ} 02^{\prime} \mathrm{N}, 1450 \mathrm{~m}$, lower montane rain forest zone, planted trees on and adjacent to campground, on bark (lower stem), 30 Jun 2002, Lücking $15239 d$ (F, INB); $83^{\circ} 00^{\prime} \mathrm{W}, 9^{\circ} 02^{\prime} \mathrm{N}$, $1500-1600 \mathrm{~m}$, montane rain forest zone, disturbed primary forest and secondary vegetation dominated by Cecropia, on bark (lower stem), 30 Jun 2002, Lücking $15208 a$ (CR, F, INB). Las Cruces Biological Station and Wilson Botanical Garden near San Vito, 900-1000 m, montane rain forest zone, planted vegetation and disturbed forest, 10-24 Oct 2004, Lücking 18027 (F), 18028 (CR), 18047 (CR), 18050 (USJ). Monteverde Cloud Forest Reserve (Arenal Conservation Area), $1500-1600 \mathrm{~m}, 10^{\circ} 18^{\prime} \mathrm{N}, 84^{\circ} 47^{\prime} \mathrm{W}, 19$ Jan 2003 , Chaves 270 (INB). San José: San Pedro de Montes de Oca, 4 Oct 1929, Thomas 8318 (FH).

Graphis inspersostictica Sipman \& Lücking, sp. nov. Figure 25C-D.

Sicut Graphis bettinae sed acidum sticticum continente differt. Holotype. COSTA RICA. San
José: Los Santos Forest Reserve, Cerro de la Muerte Biological Station (Pacífico Central Conservation Area), Talamanca Ridge, $83^{\circ} 45^{\prime} \mathrm{W}$, $9^{\circ} 34^{\prime} \mathrm{N}, \quad 3100-3400 \mathrm{~m}$, upper montane cloud forest zone, partly disturbed subparamo shrub and low forest, on bark (twig), 3 Jul 2002, Sipman 48189 (INB-3947133, holotype; B, isotype).

DESCRIPTION-Thallus corticolous, $2-5 \mathrm{~cm}$ diam., $30-70 \mu \mathrm{m}$ thick, continuous; surface uneven, yellowish gray; prothallus absent. Thallus in section with thick cartilaginous upper cortex, irregular algal layer and clusters of crystals. Apothecia lirelliform, flexuose, partly branched, prominent, with thin complete thalline margin, 1-5 mm long, $0.25-0.35 \mathrm{~mm}$ wide, $0.2-$ $0.3 \mathrm{~mm}$ high; disc concealed; proper margin thick, labia entire, dark gray to grayish black; thalline margin laterally thick, pale gray, apically thin (cortex), gray. Excipulum entire, completely carbonized, 70-130 $\mu \mathrm{m}$ wide, black; laterally covered by corticate algiferous thallus including clusters of crystals; hypothecium prosoplectenchymatous, $10-15 \mu \mathrm{m}$ high, colorless to pale yellowish; hymenium 130-170 $\mu \mathrm{m}$ high, colorless, strongly inspersed (paraphyses and asci hardly visible), inspersion rapidly disappearing in $\mathrm{KOH}$ (type B); epithecium granulose, 10$15 \mu \mathrm{m}$ high, olive brown. Paraphyses unbranched; asci fusiform, 120-160 × 30-40 $\mathrm{m}$. Ascospores $4-8$ per ascus, oblong, transversely 15-25-septate to rarely submuriform with $0-1$ longitudinal septa, $90-110 \times 10-14 \mu \mathrm{m}, 7-9$ times as long as wide, colorless. Secondary chemistry: stictic acid.

REMARKS-This new species is another representative of the Graphis cinerea aggregate. Graphis inspersostictica is very similar to $G$. bettinae and is the stictic acid chemomorph of that species.

ECOLOGY-Like the other species of this aggregate, Graphis inspersostictica seems to be restricted to partly exposed microsites in montane rain forests with high amount of precipitation.

\section{Graphis insulana (Müll. Arg.) Lücking \& Sip-} man, comb. nov. Figure $21 \mathrm{H}$.

Graphina insulana Müll. Arg., Bot. Jahrb. 4: 56. 1883. Holotype. Fiji, s.col. (G!).

Graphina subtartarea Müll. Arg., Flora 70: 402. 1887. Holotype. Australia (Queensland), Sayer s.n. (G!)

Graphis rudescens Nyl., Lich. Ins. Guineens.: 29. 1889. Lectotype (fide Nakanishi, annotation label in 1973). São Thomé \& Principe (Principe), Fr. Quintas s.n. (H-Nyl. 7414!). 
Graphina robusta Müll. Arg., Bull. Soc. Roy. Bot. Belg. 30: 82. 1891. Holotype. Costa Rica, Pittier $5238(\mathrm{G} !)$.

Graphis orientalis Vain., Ann. Acad. Sci. Fenn., Ser. A, 15(6): 206. 1921. Lectotype (here selected). Philippines, McGregor 18445 (TUR-Vainio 27230!).

Graphis macgregorii Vain., Ann. Acad. Sci. Fenn., Ser. A, 15(6): 207. 1921. Holotype. Marianas Islands, McGregor 607 (TUR-Vainio 27242!).

Graphina sierraleonensis C. W. Dodge, Nova Hedwigia Beih. 12: 73. 1964. Holotype. Sierra Leone, MacDonald s.n. (FH!).

Diagnosis-Thallus corticate, smooth to uneven, yellowish gray. Lirellae erumpent, rarely branched, with complete thalline cover, $1-5 \mathrm{~mm}$ long, $0.3-0.5 \mathrm{~mm}$ broad; labia entire. Excipulum laterally carbonized. Hymenium inspersed (type A). Ascospores single, muriform, 70-115 × 18$32 \mu \mathrm{m}$, hyaline. Secondary chemistry: norstictic acid.

REMARKS-Based on the discussion given by Wirth and Hale (1963), we first identified our material with the name Graphis hiascens (Fée) Nyl., but reexamination of the literature and material from Australia (Archer 2006, 2007) convinced us that the latter belongs in the $G$. plagiocarpa group, with short, sessile lirellae, where it is currently considered a synonym of $G$. cleistoblephara. As a consequence, $G$. insulana becomes the valid name for the present taxon.

Graphis insulana is recognized by its rather large, immersed-erumpent lirellae with almost complete thallus cover, laterally carbonized excipulum, inspersed hymenium, single muriform ascospores, and presence of norstictic acid. Archer (2003a) provided a detailed account on some of the species in the Graphis insulana group, indicating $G$. subserpentina Nyl. as the correct name for the species here recognized as $G$. insulana, but the latter has a clear hymenium. The original material of Graphis orientalis comprises four syntypes from different localities (all in the Philippines) and collectors [May 1910, Merrill 6716 (TUR-Vainio 27228! April 1913, Merrill 9038 (TUR-Vainio 27229! May 1919, Ramos \& Pascasio 35894 (TUR-Vainio 27231!)]. Since all belong to the same species, choosing a lectotype is rather arbitrary, and we therefore selected the specimen already cited by Archer (2003a). Since Archer (2003a) did not mention hymenial inspersion, we are unable to confirm the status of Graphis adtenuans Nyl., Graphina palmicola Müll. Arg., and G. nylanderi Patwardhan \& Kularni, listed as synonyms of $G$. subserpentina sensu Archer. Depending on whether the hymenium is inspersed or clear, they belong to either Graphis insulana or $G$. subserpentina. Another synonym of $G$. subserpentina checked by us is $G$. copelandii Vain.

Archer (2003a) treated Graphina streblocarpa as closely related to $G$. subserpentina sensu Archer and gave the chemistry, together with the different ecology, as only differences between the two taxa. However, G. streblocarpa also has an apically to peripherally instead of laterally carbonized excipulum and is thus different from both G. subserpentina (also having a clear hymenium) and $G$. insulana (having an inspersed hymenium).

Spectmens SEen-COSTA RICA. Guanacaste: Along Río Liberia SW of Liberia, $100 \mathrm{~m}$, 15 Jan 1930, Dodge \& Thomas 6572 (FH). Barra Honda National Park, Barra Honda Biological Station (Tempisque Conservation Area), Barra Honda Mountains, $85^{\circ} 21^{\prime} \mathrm{W}, 10^{\circ} 10^{\prime} \mathrm{N}, 400-500 \mathrm{~m}$, lowland to lower montane moist forest zone, disturbed primary and oldgrowth secondary forest with calcareous rock outcrops, on bark (lower trunk), 22 Mar 2004, Lücking $17559 \mathrm{c}$ (F. INB). Lomas de Barbudal Biological Reserve, Lomas de Barbudal Station (Tempisque Conservation Area), Río Tempisque Bassin, $85^{\circ} 22^{\prime} \mathrm{W}, 10^{\circ} 30^{\prime} \mathrm{N}, 100 \mathrm{~m}$, lowland to lower montane moist forest zone, disturbed gallery forest and forest remnants, on bark (lower stem), 29 Mar 2003, Lücking $16113 b$ (F, INB); on bark (lower trunk), 29 Mar 2003, Lücking 16105d (F), 16109d (F). Carara National Park, Quebrada Bonita Section (Pacífico Central Conservation Area), $84^{\circ} 35^{\prime} \mathrm{W}, 9^{\circ} 47^{\prime} \mathrm{N}, 100 \mathrm{~m}$, lowland moist forest zone, partly disturbed dense primary forest with understory dominated by Erythrochiton gymnanthus, on bark (lower trunk), 18 Jul 2002, Lizano $1 b$ (INB, USJ), $8 c$ (INB), Lücking $15614 b$ (F, INB, USJ), $15615 a(\mathrm{~F})$, $15626 b$ (F, INB, USJ).

\section{Graphis inturgescens Kremp. Figure 22H.}

Graphis inturgescens Kremp., Flora 59: 414. 1876; Graphina inturgescens (Kremp.) Müll. Arg., Flora 59: 383. 1876. Lectotype (fide Wirth \& Hale, 1978: 31). Brazil, Glaziou 6286 (BM, not seen; M, isolectotype).

Graphina acharii var. subintegra Zahlbr., Ann. Mycol. 19: 230. 1921. Syntype. Mexico, Pringle 5 p.p., 25 p.p. (MICH, not seen).

DiAGNOSIS - Thallus corticate, smooth to uneven, white-gray. Lirellae prominent, rarely branched, with complete thalline cover, 3$7 \mathrm{~mm}$ long, $0.4-0.6 \mathrm{~mm}$ broad; labia entire. Excipulum completely carbonized. Hymenium clear. Ascospores 2-4 per ascus, muriform, 80 $170 \times 15-30 \mu \mathrm{m}$, hyaline. Secondary chemistry: no substances detected by TLC.

REMARKS - Wirth and Hale (1978) listed this taxon as synonym of Graphis acharii, but it 
differs by its entire lirellae and slightly deviating thallus and labia morphology. The species seems to be more closely related to $G$. illinata, which has single-spored asci.

Specinens Seen-COSTA RICA. Cartago: Tapantí National Park. Macizo de La Muerte Section (La Amistad Pacífico Conservation Area). disturbed oak forest. 3000-3200 m, Jul 2002, Sipman 48220 (INB). San José: Río Macho Forest Reserve. Ojo de Agua, $83^{\circ} 49^{\prime} \mathrm{W}, 9^{\circ} 37^{\prime} \mathrm{N}$. secundary scrub near houses on ridge, 3000 m, 21 Mar 2000, Sipman \& Umaña 46589 (B, INB).

\section{Graphis leprographa Nyl. Figure 25E-F.}

DiAGNOSIS-Thallus corticate, smooth to uneven, yellowish gray. Lirellae erumpent, unbranched. with lateral thalline margin, 0.5 $1.5 \mathrm{~mm}$ long, $0.25-0.35 \mathrm{~mm}$ broad; labia entire. Excipulum completely carbonized. Hymenium inspersed (type A). Ascospores 1(-2) per ascus, muriform, $60-110 \times 16-30 \mu \mathrm{m}$, hyaline. Secondary chemistry: norstictic acid.

REMARKS-An apparently rare species characterized by immersed-erumpent lirellae with entire labia and completely carbonized excipulum and norstictic acid as secondary compound. Lirellae morphology and chemistry indicate close relationship with Graphis insulana, which differs by its laterally carbonized excipulum and usually longer lirellae. The present, corticolous material agrees well with the saxicolous type collection.

Specimens Seen-COSTA RICA. Puntarenas: Esparza-Macacona villages (Pacifico Central Conservation Area), Esparza, $84^{\circ} 39^{\prime} \mathrm{W}, 10^{\circ} 02^{\prime} \mathrm{N}, 250 \mathrm{~m}$, lowland moist forest zone, planted palm trees, on bark (lower trunk), 15 Mar 2004, Lïcking 17430a (F).

\section{Graphis leptocarpa Fée. Figure 11E.}

Graphis leptocarpa Fée, Essai Crypt. Ecorc.: 36. 1824. Lectotype (fide Wirth \& Hale, 1978: 18). South America, unknown locality, Humboldt \& Bonpland s.n. (G!).

DIAGNOSIS - Thallus corticate, smooth to uneven, yellowish gray. Lirellae erumpent, rarely branched, with lateral thalline margin, $1-3 \mathrm{~mm}$ long, $0.15-0.25 \mathrm{~mm}$ broad; labia entire. Excipulum laterally carbonized. Hymenium inspersed (type A). Ascospores 8 per ascus, transversely 711 -septate, $20-40 \times 6-8 \mu \mathrm{m}$, hyaline. Secondary chemistry: stictic and constictic acids.

REMARKS - A typical representative of the Graphis lineola aggregate, that is, species of the G. scripta group with laterally carbonized excipulum and concealed disc. Graphis lineola differs in lacking lichen substances but is otherwise identical.
Previously reported for Costa Rica by Müller Argoviensis (1893a). The material identified under that name in FH represents G. caribica.

Specimens Seen-COSTA RICA. Puntarenas: Mellizas, border to Panama (La Amistad Pacífico Conservation Area), $1400-1500 \mathrm{~m}, 8^{\circ} 53^{\prime} \mathrm{N}, 82^{\circ} 46^{\prime} \mathrm{W}, 28$ Aug 2002, Chaves 13c (INB), Navarro 5282g (INB).

Graphis leptoclada Müll. Arg. Figure 9G.

Graphis leptoclada Müll. Arg., Flora 65: 335. 1882; Opegrapha rimulosa Mont. \& Bosch, Lich. Java: 4. 1857 [nom. illeg., ICBN Art. 53.1; non Opegrapha rimulosa Mont.]. Lectotype (fide Archer, 2001e: 255). Indonesia (Java), Junghuhn s.n. (G!; ex herb. Hampe 1877).

Graphis rigidula Müll. Arg., Bull. Soc. Roy. Bot. Belg. 30: 78. 1891. Lectotype (fide Wirth \& Hale, 1978: 21). Costa Rica, Pittier 5291 (G!).

DiAGNOSIS-Thallus corticate, smooth to uneven, white-gray. Lirellae erumpent, partly branched, with lateral thalline margin, 1-5 mm long, $0.15-0.25 \mathrm{~mm}$ broad; labia striate. Excipulum laterally (to thinly completely) carbonized. Hymenium clear. Ascospores 8 per ascus, transversely 913-septate, 35-65 × 7-12 $\mu \mathrm{m}$, hyaline. Secondary chemistry: no substances detected by TLC.

REMARKS - This taxon was identified by previous authors as Graphis rigidula Müll. Arg. (Wirth \& Hale, 1978; Staiger, 2002), but reexamination of the type material convinced us that $G$. leptoclada and G. rigidula are conspecific, and $G$. leptoclada is the earlier name. The type specimens differ slightly in ascospore size (3550 versus $40-65 \mu \mathrm{m})$, but other available material has ascospores usually $40-50 \mu \mathrm{m}$ long, which connects both ends of the variation. Archer (2006) synonymized $G$. leptoclada with $G$. duplicata, but the latter has lirellae lacking a thalline margin and smaller ascospores.

Graphis leptoclada belongs in a complex of closely related species differing in minor morphological and anatomical details (thalline margin, excipulum carbonization, ascospore size, and septation). Most similar is $G$. longula, which has longer ascospores $(50-80 \mu \mathrm{m})$ and a completely carbonized excipulum. Graphis rimulosa differs by its completely carbonized excipulum, and its lirellae lack a thalline margin. Another related species is G. striatula, which agrees with G. rimulosa in excipulum structure and ascospore size, but has prominent lirellae lacking a thalline margin.

Graphis leptoclada (as G. rigidula) was identified by Dodge in his material from Costa Rica, but the material is Graphis supertecta. 
SpeCIMENS SEEN-COSTA RICA. Alajuela: Arenal National Park (Arenal Conservation Area), Heliconias trail, $500-600 \mathrm{~m}, 10^{\circ} 27^{\prime} \mathrm{N}, 84^{\circ} 44^{\prime} \mathrm{W}$, secondary forest, 9 Jan 2004. Chaves 1117 (INB). Volcán Tenorio National Park, Pilón Biological Station (ArenalTempisque Conservation Area), Tilarán Ridge, $84^{\circ} 59^{\prime} \mathrm{W}, 10^{\circ} 43^{\prime} \mathrm{N}, 700-900 \mathrm{~m}$. lower montane cloud forest zone, partly disturbed primary forest, on bark (branch, fallen), 16 Mar 2004. Sipman 51914 (B. INB). Cartago: Tapantí National Park (La Amistad Pacífico Conservation Area), trail to waterfall. 1400-1500 m, $9^{\circ} 44^{\prime} \mathrm{N}, 83^{\circ} 47^{\prime} \mathrm{W}, 2$ Apr 2003. Chaves 514 (INB). Guanacaste: Lomas Barbudal Biological Reserve (Tempisque Conservation Area), $100-200 \mathrm{~m}$, $10^{\circ} 27^{\prime} \mathrm{N}, 85^{\circ} 21^{\prime} \mathrm{W}, 1$ Oct 2002. Chaves 70c (INB). Monte Alto Forest Reserve, Monte Alto Biological Station (Tempisque Conservation Area), Nicoya Peninsula. $85^{\circ} 24^{\prime} \mathrm{W}, 10^{\prime} 02^{\prime} \mathrm{N}, 450-550 \mathrm{~m}$, lowland to lower montane moist forest zone. disturbed primary and old-growth secondary forest, on bark (branch, fallen), 21 Mar 2004. Lücking 17510n (F). Puntarenas: Las Cruces Biological Station and Wilson Botanical Garden near San Vito, 900-1000 m, montane rain forest zone, planted vegetation and disturbed forest. 16 Oct 2004, Mata García s.n. (NB).

\section{Graphis librata C. Knight. Figure $10 \mathrm{G}$}

Graphis librata C. Knight, Trans. Proc. New Zeal. Inst. 16: 404. 1884. Lectotype (fide Hayward. 1977: 571). New Zealand, Knight 67:23 (welT. not seen).

Graphis diaphoroides Müll. Arg.. Flora 69: 316. 1886. Holotype. South Africa (Transvaal). Wilms 11 (G!).

Graphis celtidis Müll. Arg.. Bull. Herb. Boiss. 3: 45. 1895. Syntypes. USA (Louisiana). Langlois 742. 744 (PH, not seen).

?Graphis filiformis Adaw. \& Makhija, Mycotaxon 99: 314. 2007. Holotype. India, Mhaskar 71.54 (AMH, photograph seen).

DIAGNOSIS-Thallus corticate, smooth to uneven, yellowish gray. Lirellae erumpent. partly branched, with lateral thalline margin. 1-3 mm long, $0.15-0.25 \mathrm{~mm}$ broad: labia entire. Excipulum laterally (to thinly completely) carbonized. Hymenium clear. Ascospores 8 per ascus, transversely 5-9-septate, $20-30 \times 5-8 \mu \mathrm{m}$. hyaline. Secondary chemistry: norstictic and connorstictic acids.

REMARKS-A typical representative of the Graphis lineola aggregate in the G. scripta group. which is characterized by erumpent lirellae with entire labia. lateral thallus margin. laterally carbonized excipulum, and small. transversely septate ascospores. Within this aggregate. species are distinguished chiefly by their chemistry and hymenium inspersion. $G$. librata producing norstictic acid and lacking inspersion.

The type material of Graphis filiformis agrees well with $G$. librata. a species not discussed in the protologue of the former, except for having very long lirellae (over $10 \mathrm{~mm}$ long). Since short lirellae are characteristic of $G$. librata and related taxa, $G$. filiformis might indeed represent a different species, then differing only in the length of the lirellae.

Specimens SeEn_COSTA RICA. Guanacaste: Barra Honda National Park. Barra Honda Biological Station (Tempisque Conservation Area). Barra Honda Mountains, $85^{\prime} 21^{\prime} \mathrm{W} .10^{\circ} 10^{\prime} \mathrm{N}, 400-500 \mathrm{~m}$, lowland to lower montane moist forest zone, disturbed primary and old-growth secondary forest with calcareous rock outcrops, on bark (twig, shrub). 22 Mar 2004. Sipman 52060 (B. INB). Lomas Barbudal Biological Reserve (Tempisque Conservation Area), 100-200 m, 10 27' N $85^{\circ} 21^{\prime} \mathrm{W} .1$ Oct 2002. Chaves 69a (INB): 5 Oct 2002 Chaves $77 b$ ( $\mathrm{NB}$ ): Lomas de Barbudal Station (Tempisque Conservation Area). Río Tempisque Bassin, $85^{\prime} 22^{\prime} \mathrm{W} .10^{\prime} 30^{\prime} \mathrm{N}, 100 \mathrm{~m}$. lowland to lower montane moist forest zone, disturbed gallery forest and forest remnants. on bark (lower trunk). 29 Mar 2003. Lücking 16100d (F). Monte Alto Forest Reserve. Monte Alto Biological Station (Tempisque Conservation Area). Nicoya Peninsula. $85^{\prime} 24^{\prime} \mathrm{W}, 10^{\circ} 02^{\prime} \mathrm{N}$. 450$550 \mathrm{~m}$. lowland to lower montane moist forest zone. disturbed primary and old-growth secondary forest. on bark (branch. fallen). 21 Mar 2004. Lücking 17510a (CR. F. INB. USJ); on bark (lower trunk). 21 Mar 2004. Aptroot 60744 (ABL, INB). Palo Verde National Park. Palo Verde Station (Tempisque Conservation Area). Rio Tempisque Bassin. 85'21'W. 10:21'N. $10 \mathrm{~m}$. lowland to lower montane moist forest zone. secondary forest and open secondary regetation. on bark (lower trunk). 27 Mar 2003. Lücking 16503g (CR. F. INB): on bark (twig), 27 Mar 2003. Buck 43923 (INB. NY); on bark (lower trunk). 28 Mar 2003. Buck 43951 (CR. NY). S of Liberia. 100 m. roadsides. 16 Jan 1930. Dodge \& Thomas 10 (FH). Hitoy Cerere Biological Reserve. Hitoy Cerere Biological Station (La Amistad Caribe Conservation Area). Talamanca Ridge. $83^{\circ} 02^{\prime} \mathrm{W} .9^{\prime} 40^{\prime} \mathrm{N} .100-150 \mathrm{~m}$. lowland to lower montane rain forest zone. exposed trees and fence posts along pasture, on wood (fence post). 10 Mar 2004. Aptroot 60259 (ABL. INB). 60269 (ABL. INB).

Graphis lineola Ach. Figure 11A-B.

Graphis lineola Ach.. Lichenogr. Univ: 264. 1810 Holotype. West Indies. unknown locality. Swartz S.n. (H-Ach $58+$ !)

Graphis handelii Zahlbr. in Handel-Mazzetti. Symb. Sin. 3: 44. 1930. Syntypes. China (Yunnan). Handel-Maz=etti 11403 , 12788 (w!).

DiAGNosis-Thallus corticate, smooth to uneven. white-gray. Lirellae erumpent. partly branched. with lateral thalline margin. 1-3 mm long. 0.1-0.2 mm broad: labia entire. Excipulum laterally carbonized. Hymenium inspersed (type A). Ascospores $S$ per ascus. transwersely 7-9. septate, $20-40 \times 6-8 \mu \mathrm{m}$. hyaline. Secondary chemistry: no substances detected by TLC. 
REMARKS-This name has often be used for tropical "Eugraphis" species, that is, species resembling Graphis scripta but occurring in the tropics (Wirth \& Hale, 1978). The latter authors also note that the tropical "Eugraphis alliance is one of the most frustrating species complexes in the family." As a matter of fact, the tropical "Eugraphids," that is, species with entire labia, laterally carbonized excipulum, and small transversely septate ascospores, belong to three different aggregates, and the species are rather easily distinguished: (1) the Graphis scripta aggregate, characterized by exposed discs; (2) the $G$. lineola aggregate, characterized by concealed discs and rather short and straight, mostly unbranched, boat-shaped lirellae; and (3) the $G$. farinulenta aggregate, with concealed discs and elongate, very slender, usually wavy lirellae and often ecorticate, farinose thallus. As a whole, there are probably more than 20 species that can be assigned to the "Eugraphis alliance." Graphis lineola was previously reported for Costa Rica by Müller Argoviensis (1893a).

Several specimens collected by Dodge in Costa Rica housed in $\mathrm{FH}$ and identified as Graphis lineola belong to other species, that is, $G$. chondroplaca, G. geraensis, G. plagiocarpa, and Glyphis substriatula (Nyl.) Staiger.

SPECIMENS SEEN-COSTA RICA. Alajuela: Volcán Tenorio National Park, Pilón Biological Station (Arenal-Tempisque Conservation Area), Tilarán Ridge, $84^{\circ} 59^{\prime} \mathrm{W}, 10^{\circ} 43^{\prime} \mathrm{N}, 700 \mathrm{~m}$, lower montane cloud forest zone, exposed trees and fence posts along pasture, on bark (lower trunk), 16 Mar 2004, Aptroot 60569 (ABL, INB). Limón: Hitoy Cerere Biological Reserve, Hitoy Cerere Biological Station (La Amistad Caribe Conservation Area), Talamanca Ridge, $83^{\circ} 02^{\prime} \mathrm{W}, 9^{\circ} 40^{\prime} \mathrm{N}, 150-300 \mathrm{~m}$, lowland to lower montane rain forest zone, partly disturbed primary forest, on bark (lower trunk), 10 Mar 2004, Aptroot 60166 (ABL, INB). Puntarenas: Carara National Park, Quebrada Bonita Section (Pacífico Central Conservation Area), $84^{\circ} 35^{\prime} \mathrm{W}, 9^{\circ} 47^{\prime} \mathrm{N}, 100 \mathrm{~m}$, lowland moist forest zone, partly disturbed dense primary forest with understory dominated by Erythrochiton gymnanthus, on bark (lower stem), 18 Jul 2002, Lücking $15618 b$ (F, INB). Potrero Grande savannas (La Amistad Pacífico Conservation Area), Terraba Valley, Clavera, $83^{\circ} 11^{\prime} \mathrm{W}, 8^{\circ} 59^{\prime} \mathrm{N}, 250 \mathrm{~m}$, lowland moist forest savanna zone, disturbed roadside savanna and pasture, on bark (lower trunk), 3 Jul 2002, Lücking 15326 c (F). San José: San Jose, Parque Bolivar, 1050 m, 12 Sep 1912, Dodge 4314 (FH).

\section{Graphis litoralis Lücking, Sipman \& Chaves, sp. nov. Figure 10D.}

Sicut Graphis caesiella sed acidum norsticticum, salazinicum et protocetraricum continens. Holo- type. COSTA RICA. Limón: Gandoca-Manzanillo Wildlife Refuge, Manzanillo Section (La Amistad Caribe Conservation Area), Manzanillo, $82^{\circ} 53^{\prime} \mathrm{W}, 9^{\circ} 38^{\prime} \mathrm{N}$, sea level, lowland coastal moist forest zone, disturbed coastal vegetation with Cocos mucifera, Coccoloba uvifera, on bark (lower stem), 11 Mar 2004, Lïcking $17098 b$ (CR, holotype; F, isotype).

Paratypes. COSTA RICA. Limón: Same locality, on bark (lower trunk), 11 Mar 2004, Lü̈cking 17088 e (F), Lücking 17090e (F).

DESCRIPTION-Thallus corticolous, $1-3 \mathrm{~cm}$ diam., $30-70 \mu \mathrm{m}$ thick, continuous; surface uneven, largely ecorticate, pale greenish to bluish gray; prothallus absent. Thallus in section mostly lacking cortex, with irregular algal layer and abundant clusters of crystals. Apothecia lirelliform, flexuose, branched, erumpent, with lateral thalline margin, $1-5 \mathrm{~mm}$ long, $0.1-0.2 \mathrm{~mm}$ wide, $0.1-0.2 \mathrm{~mm}$ high; disc concealed or rarely slightly exposed; proper margin distinct, labia entire, black but usually white pruinose; thalline margin laterally thick, pale gray. Excipulum entire, laterally carbonized, 20-50 $\mu \mathrm{m}$ wide, black; laterally covered by corticate algiferous thallus including clusters of crystals; hypothecium prosoplectenchymatous, 5-10 $\mu \mathrm{m}$ high, colorless; hymenium 70 $120 \mu \mathrm{m}$ high, colorless, clear; epithecium granulose, 5-10 $\mu \mathrm{m}$ high, brownish. Paraphyses unbranched; asci fusiform, 70-100 $\times 20-30 \mu \mathrm{m}$. Ascospores 8 per ascus, oblong, transversely 7-9septate, $30-35 \times 6-8 \mu \mathrm{m}, 4-6$ times as long as wide, colorless. Secondary chemistry: norstictic, salazinic and protocetraric acids.

REMARKS - The present material all comes from the same locality, coastal beach vegetation in the southeastern part of the Caribbean coast of Costa Rica. The combination of three different secondary substances is rather unusual in the genus Graphis but has been reported for a few species, such as the eastern paleotropical $G$. subasahinae Nagarkar \& Patw. (Nagarkar \& Patwardhan, 1982). That species is rather similar to $G$. litoralis but differs in having stictic instead of protocetraric acid and apparently nonpruinose labia. Graphis litoralis is also somewhat reminescent of $G$. caesiella, but the latter has a corticate thallus and norstictic acid only. Graphis hyphosa superficially resembles G. litoralis but has stellate lirellae clustered in pseudostromata and a completely carbonized excipulum and lacks secondary substances.

ECOLOGY - Possibly a lowland coastal species exposed to high temperature and high light levels. 
Graphis longula Kremp. Figure 13G.

Graphis longula Kremp., Flora 59: 380. 1876. Lectotype (fide Wirth \& Hale, 1976: 19). Brazil, Glaziou 5497 (G!).

DiAgNosis-Thallus corticate, smooth to uneven, white-gray. Lirellae erumpent, partly branched, with lateral thalline margin, $1-10 \mathrm{~mm}$ long, $0.3-0.4 \mathrm{~mm}$ broad; labia striate. Excipulum (laterally to) completely carbonized. Hymenium clear. Ascospores 6-8 per ascus, transversely 1117-septate, $50-80 \times 10-13 \mu \mathrm{m}$, hyaline. Secondary chemistry: no substances detected by TLC.

REMARKS-This species is somewhat transitional between the Graphis duplicata and $G$. acharii groups. The usually black labia resemble the former, but the well-developed thalline margin reminds of $G$. myrtacea in the G. acharil group. The ascospores are intermediate.

The species was mentioned for Costa Rica by Wirth and Hale (1978), who listed G. flavicans Müll. Arg. as a synonym. However, the latter is a member of the $G$. acharii group, with lirellae completely covered by a thallus layer and longer ascospores.

Specimens Seen-COSTA RICA. Puntarenas: La Amistad International Park, Altamira Station (La Amistad Pacífico Conservation Area), Talamanca Ridge, $83^{\circ} 00^{\prime} \mathrm{W}, 9^{\circ} 02^{\prime} \mathrm{N}, 1600-1800 \mathrm{~m}$, montane rain forest zone, secondary forest and open secondary vegetation dominated by Cecropia, on bark (lower trunk), 1 Jul 2002, Sipman 48043k (B. INB). Marenco Ecological Station (Osa Conservation Area), 0-50 m, Feb 1997, Lücking 97-114 (F), 97-140 (F), 97-151 (F), 97-221 (F)

\section{Graphis lucifica R. C. Harris. Figure 10A.}

Graphis lucifica R. C. Harris, Some Florida Lichens: 12. 1990. Holotype. U.S.A., Harris 25174 (NY!).

Graphis rimulosa var. tetraspora Redinger, Ark. Bot 27(3): 36. 1935. Lectotype (here selected!). Brazil, Malme 3605 (s 6490!). Syntypes. Brazil. Malme 2254 (s 6491!). Brazil, Malme 2406 (s 6492!).

DiAgNosis-Thallus corticate, smooth to uneven, white, UV+ yellow. Lirellae erumpent, partly branched, lacking thalline margin, 1$5 \mathrm{~mm}$ long, $0.2-0.3 \mathrm{~mm}$ broad; labia striate. Excipulum laterally carbonized. Hymenium clear. Ascospores 8 per ascus, transversely 5-7septate, $20-40 \times 7-10 \mu \mathrm{m}$, hyaline. Secondary chemistry: lichexanthone.

REMARKS-This species is most similar to Graphis duplicata, from which it differs chiefly by the presence of lichexanthone. Graphis haleana differs chiefly in the larger ascospores. The three syntypes of $G$. rimulosa var. tetraspora are conspecific, and the specimen annotated by Archer (1999) is here selected as lectotype.

Specimens SeEn_COSTA RICA. Guanacaste: Monte Alto Forest Reserve, Cerro Romo (Tempisque Conservation Area), Nicoya Peninsula, $85^{\circ} 24^{\prime} \mathrm{W}$. $10^{\circ} 00^{\prime} \mathrm{N}, 750-900 \mathrm{~m}$, lowland to lower montane moist forest zone, exposed trees and fence posts along pasture, on bark (lower trunk), 22 Mar 2004. Lücking $17581(\mathrm{~F}, \mathrm{INB})$.

\section{Graphis lumbricina Vain. Figure $16 \mathrm{G}-\mathrm{H}$.}

Graphis lumbricina Vain., Hedwigia 38: 256. 1899 Lectotype (fide Wirth \& Hale, 1978: 20). Guadeloupe, Duss 1036 (TUR-Vainio 27524!, FH, isolectotype!).

DiAGNOSIS-Thallus corticate, smooth to uneven, yellowish gray. Lirellae prominent, unbranched, with (apically thin) complete thalline cover that frequently flakes off, $1-5 \mathrm{~mm}$ long, $0.4-0.6 \mathrm{~mm}$ broad; labia striate. Excipulum completely carbonized. Hymenium clear. Ascospores 4-8 per ascus, transversely 13-19-septate. 95-115 × 17-21 $\mathrm{m}$, hyaline (sometimes pale gray-brown when old), I+ violet-blue (structurally similar to those of $G$. elegans). Secondary chemistry: norstictic acid.

REMARKS-This is one of the most characteristic species of the genus Graphis, apparently with a Caribbean distribution. The large, robust lirellae resemble those of $G$. acharii, but the thin complete thalline cover soon flakes off to expose jet-black labia. Also, this is one of the few species in Graphis where it can be readily observed that new lirellae are formed within old ones and thus cause the strong striation observed in older lirellae. We have studied a large number of collections from the Caribbean (Jamaica, Guadeloupe, Dominica, St. Vincent; Lücking et al., $2008 \mathrm{~b}$ ), and this combination of characters is constant among all gatherings. Similar lirellae are found only in the newly described $G$. nudaeformis, which has entire labia and lacks secondary substances. Otherwise, it seems that $G$. elegans is most closely related to G. lumbricina. differing chiefly by its smaller ascospores.

According to the description. the specimens cited as Graphis cf. lumbricina by Staiger (2002) do belong to this taxon. Also, one specimen cited with an asterisk under $G$. elegans represents $G$. lumbricina.

Specimens Seen COSTA RICA. Cartago: Genesis II Cloud Forest Reserve (La Amistad Pacifico Conservation Area). Talamanca Ridge. 2200-2500 m. 
montane rain forest to upper montane cloud forest zone, Feb 1997, Lücking 97-59 (F). Cartago: Río Macho Forest Reserve, La Chonta, $5 \mathrm{~km} \mathrm{~S}$ of $\mathrm{El}$ Empalme on road to San Isidro del General, $83^{\circ} 56^{\prime} \mathrm{W}$, $9^{\circ} 42^{\prime} \mathrm{N}, 2300 \mathrm{~m}$, fence posts and forest relics in pasture fields on mountain ridge, 11 Nov 1988, Sipman et al. 41749 (B, CR). San José: Potreros between Guayabillos and Cabeza de Vaca, 2150-2350 m, 4 Nov 1929, Dodge \& Thomas 6472 (FH). Rancho Redondo, 2220 2600 m, 16 Nov 1929, Dodge \& Thomas 5497 (FH).

\section{Graphis macella Kremp. Figure 23C.}

Graphis macella Kremp., Flora 59: 380. 1876; Graphina macella (Kremp.) Müll. Arg., Flora 63: 39. 1880. Lectotype (fide Wirth \& Hale, 1978: 40). Brazil, Glaziou $6289 b$ (M).

Graphis subvestita Vain. Acta Soc. Fauna Flora Fenn. 7: 103. 1890; Graphina subvestita (Vain.) Aptroot, Fung. Div. 9: 30. Holotype. Brazil, Vainio s.n. (TUR-Vainio 27186!; Vainio, Lich. Bras. Exs. 933)

Graphina carbocarpa Redinger, Ark. Bot. 26A(1): 26. 1933. Holotype. Brazil, Mosén 2143 (S 2203!).

DiAGNOSIS-Thallus corticate, smooth to uneven, white-gray. Lirellae erumpent to prominent, partly branched, with (apically thin) complete thalline cover, 1-4 mm long, 0.5$0.7 \mathrm{~mm}$ broad; labia striate. Excipulum (laterally to) completely carbonized. Hymenium clear. Ascospores single, muriform, 70-170 $\times 20$ $40 \mu \mathrm{m}$, hyaline. Secondary chemistry: no substances detected by TLC.

REMARKS-Graphis macella belongs in a complex of species characterized by partially to fully thallus-covered lirellae with striate labia; completely carbonized excipulum; mostly single, large muriform ascospores; and lacking lichen substances. These taxa closely resemble G. acharii, which differs in having 2-6 ascospores per ascus. Graphina carbocarpa agrees rather well with $G$. macella and especially with our material from Costa Rica. In addition, there are at least seven other names that generally agree with $G$. macella but differ in lirellae morphology: Graphina consanguinea Müll. Arg., Graphis pseudosophistica Vain., G. includens Vain., G. subvestita Vain., Graphina heteroplacoides Redinger, G. crystallifera Redinger, and G. myrtacea Müll. Arg. The first three have more or less immersed lirellae with thick thalline cover; these represent a distinct taxon here named Graphis consanguinea. Graphis subvestita has very short, prominent lirellae with thick thalline cover and is somehow intermediate between G. macella and Graphina consanguinea. Graphina heteroplacoides most probably is the same as $G$. consanguinea, but we have not seen the type material of that species. Graphina myrtacea is here recognized as an autonomous taxon (see below), with $G$. crystallifera as synonym. Interestingly, all names were established on material from Brazil, and the entire aggregate seems to be restricted to the Neotropics.

Graphis macella was reported (as Graphina) from Costa Rica by Breuss (2004); we have not seen the material and cannot state whether it is $G$. macella in our sense or represents either $G$. consanguinea or G. myrtacea.

SpeCIMENS SEEN_COSTA RICA. Guanacaste: Carretera to Santamaria near Liberia, 100 m, 14 Jan 1930 , Dodge \& Thomas s.n. (FH). Finca del Estado, border of Guanacaste National Park, Pitilla Section (Guanacaste Conservation Area), 400-500 m, $11^{\circ} 01^{\prime} \mathrm{N}$, $85^{\circ} 24^{\prime} \mathrm{W}, 16$ Mar 2006, Chaves 2511 (INB), 2530 (INB). Puntarenas: La Amistad International Park, Altamira Station (La Amistad Pacífico Conservation Area), Talamanca Ridge, $82^{\circ} 59^{\prime} \mathrm{W}, 9^{\circ} 02^{\prime} \mathrm{N}, 1800 \mathrm{~m}$, montane rain forest zone, abandoned pasture with scattered shrubs and trees, on bark (stem, shrub), 1 Jul 2002, Sipman 48097 (B, INB). Las Cruces Biological Station and Wilson Botanical Garden near San Vito, 900-1000 m, montane rain forest zone, planted vegetation and disturbed forest, 10-24 Oct 2004, Lücking 18019 (F); 16 Oct 2004, Murillo \& Castillo B-0025 (INB), Orozco 13 (INB).

\section{Graphis marginata Raddi. Figure 16E.}

Graphis marginata Raddi, Memor. Soc. Ital. Sc. 18: 344. 1820. Type. Brazil, s.col. (not seen).

Graphis leucoparypha Kremp., Nuovo Giorn. Bot. Ital. 7: 35 (1875). Type. Malaysia (Borneo: Sarawak), Beccari 134 (M, not seen).

Graphis turgidula var. norstictica A. W. Archer, Aust. Syst. Bot. 14: 267. 2001. Holotype. Australia, Streimann 56877 (CANB, not seen).

DiAgNOSIS-Thallus corticate, smooth to uneven, yellowish gray. Lirellae prominent, unbranched, with thick lateral thalline margin, 1$6 \mathrm{~mm}$ long, $0.4-0.6 \mathrm{~mm}$ broad; labia entire. Excipulum completely carbonized. Hymenium clear. Ascospores 4-8 per ascus, transversely 1125 -septate, 50-120 × 9-18 $\mu \mathrm{m}$, hyaline. Secondary chemistry: norstictic and connorstictic acids.

REMARKS-This species belongs in the Graphis rhizocola group and is most similar to $G$. rustica, which differs mainly in the presence of stictic instead of norstictic acid. Archer (2001d) apparently was unaware of the name $G$. marginata when he described G. turgidula var. norstictica. He then established Graphis leucoparypha as the supposedly earliest name for this taxon (Archer, 2006), but G. marginata antedates $G$. leucoparypha. 
Specimens SeEn-COSTA RICA. Limón: Hitoy Cerere Biological Reserve (La Amistad Caribe Conservation Area), El Espavel trail, 200-300 m, 9 $40^{\prime} \mathrm{N}$, $83^{\circ} 01^{\prime} \mathrm{W}, 2$ Sep 2003, Chaves 1081 (INB).

Graphis mexicana (Hale) Lücking, Lumbsch \& Kalb. Figure 23G.

Graphis mexicana (Hale) Lücking, Lumbsch \& Kalb in Mangold et al., Lichenologist 40: 44. 2008; Thelotrema mexicanum Hale, Phytologia 27: 495. 1974. Holotype. Mexico, Nakanishi 82 (Us!).

Graphis muscicola (Kalb) Staiger, Bibl. Lichenol. 85: 243. 2002; Graphina muscicola Kalb, Sched. Lich. Neotrop., Fasc. 10: 8. 1988. Holotype. Ecuador, Kalb s.n. (hb. Kalb!, Kalb, Lich. Neotrop. 422).

Topeliopsis globosa Aptroot, Fungal Diversity 9: 25. 2002. Isotype. Brazil, Aptroot 41709 (ABL!).

DiAgNOSIS-Thallus corticate, smooth to uneven, white-gray. Lirellae sessile, round, with complete thalline cover, $0.5-1 \mathrm{~mm}$ long, 0.5$0.7 \mathrm{~mm}$ broad; labia entire. Excipulum completely carbonized. Hymenium clear. Ascospores single, muriform, 150-270 $\times 25-50 \mu \mathrm{m}$, hyaline. Secondary chemistry: no substances detected by TLC.

REMARKS-Graphis mexicana is an enigmatic species, probably widespread in the Neotropics but certainly undercollected or frequently misplaced as a pyrenocarpous taxon. It usually grows over mosses but is also found on bark, generally in montane regions. At first glance, its round apothecia resemble those of a Pertusaria rather than a Graphis, and only a detailed look reveals that the perithecioid ascomata conceal very short, sometimes even branched lirellae. It is therefore not surprising that the species was described as Thelotrema mexicanum (Hale, 1974a) and as Topeliopsis globosa (Aptroot, 2002), although the authors recognized that their new taxa were atypical for those genera. Anatomically, Graphis mexicana resembles G. illinata, although the very elongate lirellae of the latter look very different. Graphis globosa (Fée) Spreng. and Graphis hemispherica Vain. are two further species with genuinely round apothecia and belong in the same group as G. mexicana. Both differ chiefly by their smaller ascospores (80-140 $\times 20-35 \mu \mathrm{m}$; about half the size of those of $G$. mexicana), and the saxicolous $G$. hemispherica also has a brown thallus and apothecia, but this might be a modification and thus conspecific with Opegrapha globosa.

Specimens SeEn_COSTA RICA. Alajuela: Volcán Tenorio National Park, Pilón Biological Station (Arenal-Tempisque Conservation Area), Tilarán
Ridge, $84^{\circ} 59^{\prime} \mathrm{W}, 10^{\circ} 43^{\prime} \mathrm{N}, 700 \mathrm{~m}$, lower montane cloud forest zone, exposed trees and fence posts along pasture, on bark (lower trunk), 15 Mar 2004, Sipman 51759 (B, INB). Cartago: 'Tapantí National Park, Tapantí Section, Tapantí Station (La Amistad Pacífico Conservation Area), Talamanca Ridge, $83^{\circ} 47^{\prime} \mathrm{W}$, $9^{\circ} 44^{\prime} \mathrm{N}, 1700 \mathrm{~m}$, montane cloud forest zone, primary forest margin along roadside, on bark (branch, fallen), 2 Apr 2003, Buck 44039 (INB, NY); on bark (lower stem), 2 Apr 2003, Grube 11396 (CR, GZU). Tapantí National Park, Cerro de la Muerte Section (Amistad Pacífico Conservation Area), $\mathrm{km} 93$ on road (ruta 2) from Cartago to San Isidro, roadside, $83^{\circ} 45^{\prime} \mathrm{W}$, $9^{\circ} 34^{\prime} \mathrm{N}, 3000-3100 \mathrm{~m}$, upper montane cloud forest zone, disturbed low forest, on bark (lower trunk), 3 Jul 2002, Sipman 48207 (B, INB). Puntarenas: Las Cruces Biological Station and Wilson Botanical Garden near San Vito, $900-1000 \mathrm{~m}$, montane rain forest zone, planted vegetation and disturbed forest, 10-24 Oct 2004, Amtoft 3076 (INB, NY).

\section{Graphis miniata Redinger. Figure 7D.}

Graphis miniata Redinger, Ark. Bot. 27A(3): 26. 1935. Lectoype (here selected!). Brazil, Mosén 3145 (s 6493! Malme, Lich. Austroam. 319).

DiagNosis-Thallus corticate, smooth to uneven, white-gray. Lirellae prominent, rarely branched, with complete, partly detaching thalline cover, $1-5 \mathrm{~mm}$ long, $0.25-0.5 \mathrm{~mm}$ broad; labia striate, with orange, $\mathrm{K}+$ pink-purple pigment between striae. Excipulum completely carbonized. Hymenium clear. Ascospores 6-8 per ascus, terminally muriform, $80-100 \times 10-15 \mu \mathrm{m}$, hyaline. Secondary chemistry: anthraquinones.

REMARKS - This species is related to Graphis chrysocarpa but differs by its lirellae covered with a corticate thalline layer (the orange pigment being found below that layer between the striae) and its smaller, terminally muriform ascospores. A further species, G. subchrysocarpa, combines chrysocarpa-type lirellae with miniatatype ascospores.

The syntypes of Redinger's (1935) Graphis miniata all belong to the same species, and the one annotated by Archer (1999) is here selected as lectotype. Most of the lirellae have a grayish white thallus cover with the orange pigment beneath, while in some the thallus cover is missing and the lirellae are bright orange; the ascospores are partly transversely septate but eventually become terminally muriform and reach about $80-100 \times 12-15 \mu \mathrm{m}$ in size.

Specimens SeEn-COSTA RICA. Alajuela: Arenal National Park (Arenal Conservation Area), 500 $600 \mathrm{~m}, 10^{\circ} 28^{\prime} \mathrm{N}, 84^{\circ} 44^{\prime} \mathrm{W}, 9$ Jan 2004 , Chaves 1134 (INB); Heliconias trail, $500-600 \mathrm{~m}, 10^{\circ} 27^{\prime} \mathrm{N}, 84^{\circ} 44^{\prime} \mathrm{W}$, secondary forest, 9 Jan 2004, Chaves 1115 (INB). 
Huetar Norte, Boca Tapada, Refugio Nacional de Vida Silvestre Mixto Maquenque, 0-100 m, $10^{\circ} 42^{\prime} \mathrm{N}$, $84^{\circ} 11^{\prime} \mathrm{W}, 8$ May 2005, Chaves 2285 (INB). Miravalles Protection Zone, Altamira Section (Arenal Conservation Area), $600-700 \mathrm{~m}, 10^{\circ} 44^{\prime} \mathrm{N}, 85^{\circ} 05^{\prime} \mathrm{W}, 8$ Aug 2003, Chaves 1041 (INB). Volcán Tenorio National Park, Pilón Biological Station (Arenal-Tempisque Conservation Area), Tilarán Ridge, $84^{\circ} 59^{\prime} \mathrm{W}$, $10^{\circ} 43^{\prime} \mathrm{N}, 700 \mathrm{~m}$, lower montane cloud forest zone, exposed trees and fence posts along pasture, on bark (lower trunk), 16 Mar 2004, Nelsen 3768 (F); grazed, abandoned Syzygium jambos plantation surrounded by Gmelina arborea trees and pasture fields, 15 Mar 2004, Sipman 51826 (B). Cartago: Barbilla National Park (La Amistad Caribe Conservation Area), main trail to Río Danta, 400-500 m, $9^{\circ} 59^{\prime} \mathrm{N}, 83^{\circ} 29^{\prime} \mathrm{W}, 16$ Feb 2003, Cliaves 375 (INB). Río Pacuare Forest Reserve, Barbilla Station (La Amistad Caribe Conservation Area), $500-600 \mathrm{~m}, 9^{\circ} 58^{\prime} \mathrm{N}, 83^{\circ} 27^{\prime} \mathrm{W}, 13 \mathrm{Feb}$ 2003, Chaves 335 (INB). Guanacaste: Finca del Estado, border of Guanacaste National Park, Pitilla Section (Guanacaste Conservation Area), 400-500 m, $11^{\circ} 01^{\prime} \mathrm{N}, 85^{\circ} 24^{\prime} \mathrm{W}, 16$ Mar 2006, Chaves 2535 (INB). Nosara Protection Zone, Monte Alto Forest Reserve (Tempisque Conservation Area), $600-700 \mathrm{~m}, 10^{\circ} 00^{\prime} \mathrm{N}$, $85^{\circ} 24^{\circ} \mathrm{W}, 7$ Jun 2003, Chaves 700 (INB). Quebrada Azul, Tilarán (Arenal Conservation Area), 700-800 m, $10^{\circ} 31^{\prime} \mathrm{N}, 84^{\circ} 59^{\prime} \mathrm{W}, 1$ Mar 2003, Chaves 1753 (INB). Limón: Hitoy Cerere Biological Reserve (La Amistad Caribe Conservation Area), El Espavel trail, 200 $300 \mathrm{~m}, 9^{\circ} 40^{\prime} \mathrm{N}, 83^{\circ} 01^{\prime} \mathrm{W}, 2$ Sep 2003, Chaves 1081 (INB); Hitoy Cerere Biological Station (La Amistad Caribe Conservation Area), Talamanca Ridge, $83^{\circ} 02^{\prime} \mathrm{W}, 9^{\circ} 40^{\prime} \mathrm{N}, 150 \mathrm{~m}$, lowland to lower montane rain forest zone, planted trees and secondary vegetation, on wood (log), 10 Mar 2004, Nelsen $3719 b$ (INB).

Graphis mirabilis Lücking, Sipman, Umaña \& Chaves, sp. nov. Figure 19C-D.

Sicut Graphis phaeospora sed parte centrali excipuli decarbonisato differt. Holotype. COSTA RICA. Cartago: Tapantí National Park, Macizo de la Muerte Section, Cerro de la Muerte (La Amistad Pacífico Conservation Area), Talamanca Ridge, $83^{\circ} 45^{\prime} \mathrm{W}, 9^{\circ} 34^{\prime} \mathrm{N}, 3000-3100 \mathrm{~m}$, upper montane cloud forest zone, disturbed low oak forest, on bark (lower trunk), 3 Jul 2002, Sipman 48208 (INB-3947527, holotype; B, isotype).

DESCRIPTION-Thallus corticolous, $3-7 \mathrm{~cm}$ diam., $70-150 \mu \mathrm{m}$ thick, continuous; surface uneven to coarsely verrucose, pale greenish gray; prothallus absent. Thallus in section with cartilaginous upper cortex, irregular algal layer and clusters of crystals. Apothecia lirelliform, straight to flexuose, rarely branched, prominent, with thin complete thalline margin, $1-2 \mathrm{~mm}$ long, $0.5-0.7 \mathrm{~mm}$ wide, $0.3-0.4 \mathrm{~mm}$ high; disc concealed; proper margin thick, labia striate, dark brownish gray; thalline margin laterally thick, pale gray to white, apically thin (cortex), gray. Excipulum crenulate, partially carbonized (upper and basal parts only), 40-100 $\mu \mathrm{m}$ wide, basally and apically brownish black, internal parts yellowish brown; laterally covered by thick corticate algiferous thallus including clusters of crystals; hypothecium prosoplectenchymatous, 5-15 $\mu \mathrm{m}$ high, colorless to pale yellowish; hymenium 200-250 $\mu \mathrm{m}$ high, colorless, inspersed (type B); epithecium indistinct. Paraphyses unbranched; asci ellipsoid, 180-230 $\mu \mathrm{m}$ long, 35$50 \mu \mathrm{m}$ wide. Ascospores single, ellipsoid to oblong, muriform, $150-180 \times 30-45 \mu \mathrm{m}$ wide, 4-5 times as long as wide, pale brown to olive brown. Secondary chemistry: no substances detected by TLC.

REMARKS-This new species seems to belong in the Graphis cinerea aggregate but differs from all other species of the genus by the following combination of characters: excipulum apically and basally carbonized but in-between uncarbonized (the only other species with such an excipulum are Graphis immersoides and the newly described $G$. gregmuelleri, with clear hymenium and 4-8 narrower, submuriform and transversely septate ascospores, respectively), hymenium inspersed, and ascospores single, very large. Among the Graphis cinerea aggregate, $G$. phaeospora comes closest but differs in its completely carbonized excipulum and 1-4spored asci. Graphis macella in the G. acharii group is also similar but has a clear hymenium and a completely carbonized excipulum. All these taxa have a similar ecology and were found growing in the same habitats, that is, montane cloud forest.

ECOLOGY-Like the other species of this aggregate, Graphis mirabilis seems to be restricted to partly exposed microsites in montane rain forests with high amount of precipitation.

Graphis multisulcata (Müll. Arg.) Lücking \& Chaves, comb. nov. Figure 22E.

Graphina multisulcata Müll. Arg., Flora 71: 545. 1888. Holotype. Brazil, Puiggari 74 (G!).

Graphis analoga var. subradiata Nyl., Acta Soc. Sci. Fenn. 7: 465. 1863; Nylander, Ann. Sci. Nat., Ser. 4, 19: 360. 1863; Graphina analoga var. subradiata (Nyl.) Zahlbr., Cat. Lich. Univ. 2: 395. 1923. Holotype. Colombia [Nova Granata], Lindig 2725 (H-Nyl 7434!).

DiAgNosis-Thallus corticate, smooth to uneven, white-gray. Lirellae erumpent, partly branched, with (apically thin) complete thalline cover, $1-5 \mathrm{~mm}$ long, $0.2-0.3 \mathrm{~mm}$ broad; labia striate. Excipulum completely carbonized. Hymenium clear. Ascospores 4-8 per ascus, muri- 
form, $50-60 \times 15-23 \mu \mathrm{m}$, hyaline. Secondary chemistry: no substances detected by TLC.

REMARKS-This species seems to be related to Graphis acharii but differs in the less prominent, typically erumpent lirellae and the distinctly smaller ascospores. Like G. longula, it provides a link between the $G$. duplicata and $G$. acharii groups. Graphis plurispora is extremely similar and differs chiefly in the narrower ascospores (10-15 $\mu \mathrm{m}$ broad).

Specimens Seen -COSTA RICA. Alajuela: Huetar Norte, Boca Tapada, Refugio Nacional de Vida Silvestre Mixto Maquenque, 0-100 m, $10^{\circ} 42^{\prime} \mathrm{N}$, $84^{\circ} 11^{\prime} \mathrm{W}, 5$ Apr 2005, Chaves 2230 (INB-3942428).

Graphis myrtacea (Müll. Arg.) Lücking, comb. nov. Figure 23E.

Graplina nyrtacea Müll. Arg., Hedwigia 34: 33. 1895. Holotype. Brazil, Ule 127 (G!).

Graphina crystallifera Redinger, Ark. Bot. 26A(1): 29. 1933. Lectotype (fide Staiger, 2002: 225). Brazil, Malme 2311 (s!).

DiAgNOSIS-Thallus corticate, smooth to uneven, white. Lirellae erumpent, partly branched, with thick lateral thalline margin, $1-10 \mathrm{~mm}$ long, $0.5-0.7 \mathrm{~mm}$ broad; labia striate, sharply delimited, jet-black. Excipulum completely carbonized. Hymenium clear. Ascospores single, muriform, 120-160 × 30-40 $\mu \mathrm{m}$, hyaline. Secondary chemistry: no substances detected by TLC.

REMARKS-Our material of this taxon was first considered to be conspecific with Graphis macella but differs constantly in the erumpent instead of prominent lirellae that are only laterally covered by a thallus layer and conspicuously expose the upper, jet-black part of the labia. Also, the lirellae are distinctly longer on average than observed in G. macella. The two saxicolous types of Graphina myrtacea and $G$. crystallifera match this morph, and $G$. myrtacea is the earliest available epithet. Graphis myrtacea is very similar to two newly described species that grow sympatrically at the same localities. Graphis gomezii has always entire labia, 4-8-spored asci, and smaller ascospores $(35-50 \times 15-20 \mu \mathrm{m})$, while $G$. tenoriensis is characterized by its only apically carbonized excipulum. Material of Graphis myrtacea from Costa Rica in FH was identified by Dodge as Graphina analoga var. monophora (Nyl.) Zahlbr.

Specimens SEen_COSTA RICA. Alajuela: Bijagua, Alto Los Brenes Section (Arenal Conservation Area), $700-800 \mathrm{~m}, 10^{\circ} 44^{\prime} \mathrm{N}, 85^{\circ} 02^{\prime} \mathrm{W}, 7$ Aug 2003, Choves 950 (INB-3789570). Volcán Tenorio National Park, Pilón Biological Station (Arenal-Tempisque Conservation
Area), Tilarán Ridge, $84^{\circ} 59^{\prime} \mathrm{W}, 10^{\circ} 43^{\prime} \mathrm{N}, 700 \mathrm{~m}$, lower montane cloud forest zone, exposed trees and fence posts along pasture, on bark (lower stem), 15 Mar 2004 , Lücking $17214 a$ (CR, F), $17214 b$ (F, USJ), 17217 (F). Guanacaste: Volcán Tenorio National Park, Alto Masis Section (Arenal-Tilarán Conservation Area), Tilarán Ridge, $85^{\circ} 00^{\prime} \mathrm{W}, 10^{\circ} 37^{\prime} \mathrm{N}, 950-1000 \mathrm{~m}$, lower montane elfin cloud forest zone, disturbed low elfin forest and secondary vegetation, on bark (lower stem), 17 Mar 2004, Lücking $17323 a$ (CR, F, INB-4005475, USJ); on bark (twig), 17 Mar 2004, Lücking 17331 (CR, F), 17334 (F). San José: Perez Zeledón, Cordillera de Talamanca. Cerro de la Muerte, $83^{\circ} 46^{\prime} \mathrm{W}, 9^{\circ} 31^{\prime} \mathrm{N}, 3000 \mathrm{~m}$, Escalonia vegetation, 21 Feb 1996. Inberg 1240 (B).

\section{Graphis nuda (H. Magn.) Staiger \& Lücking, comb. nov. Figure 22A.}

Graphina nuda H. Magn., Ark. Bot. 3(10): 266. 1955 [non Graphis nuda Staiger, Biblioth. Lichenol. 85: 245. 2002, nom. inval. (ICBN, Art. 32, 35-37) $\equiv$ G. ovata (Fée) A. Massal. (see below)]. Holotype: U.S.A. (Hawaii), Fanrie $1025 b$ (UPS!).

DiAgNosis-Thallus corticate, smooth to uneven, white-gray. Lirellae sessile, unbranched, lacking thalline margin, jet-black, Melaspilealike, $1-2 \mathrm{~mm}$ long, $0.25-0.35 \mathrm{~mm}$ broad; labia entire. Excipulum completely carbonized. Hymenium clear. Ascospores 8 per ascus, muriform, 25-40 × 14-18 $\mu \mathrm{m}$, hyaline. Secondary chemistry: no substances detected by TLC.

REMARKS-Graphis nuda belongs to a group of species with strongly prominent, black, Melaspilea-like apothecia with entire labia and (laterally to) completely carbonized excipulum. Species of this group can be separated from each other chiefly by their ascospore septation, size, and pigmentation. Among three taxa with muriform ascospores, including $G$. ruiziana and $G$. subruiziana, $G$. nuda is distinguished by its very small ascospores. Graphis nuda is not to be confused with $G$. muda Staiger ad interim (Staiger, 2002), which belongs in the same group of species but has transversely septate ascospores with gelatinous caps. The latter is conspecific with $G$. ovata (see below).

Specimens Seen_COSTA RICA. Alajuela: Volcán Tenorio National Park, Pilón Biological Station (Arenal-Tempisque Conservation Area), Tilarán Ridge, $84^{\circ} 59^{\prime} \mathrm{W}, 10^{\circ} 43^{\prime} \mathrm{N}, 700 \mathrm{~m}$, lower montane cloud forest zone, exposed trees and fence posts along pasture, on wood (fence post), 16 Mar 2004, Lücking 17250d (F). Guanacaste: Volcán Tenorio National Park, Alto Masis Section (Arenal-Tilarán Conservation Area), Tilarán Ridge, $85^{\circ} 00^{\prime} \mathrm{W}, 10^{\circ} 37^{\prime} \mathrm{N}, 950$ $1000 \mathrm{~m}$, lower montane elfin cloud forest zone, disturbed low elfin forest and secondary vegetation, on bark (lower trunk), 17 Mar 2004, Lücking $17321 f$ (CR, F, USJ). Puntarenas: Las Cruces Biological Station 
and Wilson Botanical Garden near San Vito, 900 $1000 \mathrm{~m}$, montane rain forest zone, planted vegetation and disturbed forest, 10-24 Oct 2004, Lücking 18040 (F). San José: Los Santos Forest Reserve, Cerro de la Muerte Biological Station (Pacífico Central Conservation Area), Talamanca Ridge, $83^{\circ} 45^{\prime} \mathrm{W}, 9^{\circ} 34^{\prime} \mathrm{N}, 3100$ $3400 \mathrm{~m}$, upper montane cloud forest zone, partly disturbed subparamo shrub and low forest, on bark, Oct 2004, Chaves s.n. (F).

Graphis nudaeformis Lücking, sp. nov. Figure $15 \mathrm{E}-\mathrm{F}$.

Sicut Graphis rhizocola sed apotheciis brevioribus sessilibusque differt. Holotype. COSTA RICA. Puntarenas: Las Cruces Biological Station and Wilson Botanical Garden near San Vito, 900 $1000 \mathrm{~m}$, montane rain forest zone, planted vegetation and disturbed forest, 10-24 Oct 2004, Lücking 18025 (INB-4056171, holotype).

Paratypes. COSTA RICA. Puntarenas: Same locality, 10-24 Oct 2004, Lücking $18004 a$ (F), 18037 (F), 18044 (CR), 18045 (F).

DESCRIPTION-Thallus corticolous, $1-3 \mathrm{~cm}$ diam., $50-80 \mu \mathrm{m}$ thick, continuous; surface uneven, pale greenish gray to pale gray; prothallus absent. Thallus in section with thick cartilaginous upper cortex, irregular algal layer and clusters of crystals. Apothecia lirelliform, straight, unbranched, sessile, with thin complete thalline margin, 1-2 $\mathrm{mm}$ long, 0.4-0.6 $\mathrm{mm}$ wide, $0.3-0.5 \mathrm{~mm}$ high; disc concealed; proper margin thick, labia entire, gray to black; thalline margin rather thin (mostly cortex), gray, often flaking off and exposing jet-black lirellae. Excipulum entire, completely carbonized, $70-150 \mu \mathrm{m}$ wide, black; laterally covered by thin corticate algiferous thallus; hypothecium prosoplectenchymatous, $10-20 \mu \mathrm{m}$ high, colorless to pale yellowish; hymenium 150-200 $\mu \mathrm{m}$ high, colorless, clear; epithecium granulose, 5-15 $\mu \mathrm{m}$ high, olive brown. Paraphyses unbranched; asci fusiform, 140-180 $\times$ 30-40 $\mu \mathrm{m}$. Ascospores 4-8 per ascus, oblong, transversely 15-25-septate, $80-100 \times 10-15 \mu \mathrm{m}$, 7-9 times as long as wide, colorless. Secondary chemistry: no substances detected by TLC.

REMARKS-Graphis nudaeformis is anatomically almost identical with $G$. rhizocola but differs clearly in the very short, sessile lirellae. Graphis rhizocola is one of the most abundant species in Costa Rica and also occurs abundantly at the type locality of $G$. nudaeformis, but its lirellae are clearly distinct. Morphologically even more similar is G. tumidula, but that species has much larger ascospores. Graphis nudaeformis also resembles species of the G. nuda group, but the latter consistently lack a thalline margin.
However, in $G$. nudaeformis the thalline margin often flakes off, and the lirellae then look very similar to those of species in the G. nuda group.

ECOLOGY-Thus far only known from one locality in the montane rain forest zone, possibly with similar preferences as Graphis rhizocola and related species.

Graphis oryzaecarpa Lücking, sp. nov. Figure $23 \mathrm{H}$.

Sicut Graphis triphora sed excipulo basaliter nigro et ascosporis maioribus differt. Holotype. COSTA RICA. Cartago: Tapantí National Park, Tapantí Section, Tapantí Station (La Amistad Pacífico Conservation Area), Talamanca Ridge, $83^{\circ} 47^{\prime} \mathrm{W}$, $9^{\circ} 45^{\prime} \mathrm{N}, 1400-1600 \mathrm{~m}$, montane rain forest zone, closed primary forest and roadside, on bark (branch), 2 Apr 2003, Lücking 16579 (F, holotype).

DESCRIPTION-Thallus corticolous, $1-3 \mathrm{~cm}$ diam., $30-80 \mu \mathrm{m}$ thick, continuous; surface smooth to slightly uneven, yellowish gray; prothallus absent. Thallus in section with cartilaginous upper cortex and irregular algal layer. Apothecia rounded to oval, unbranched, sessile, with thick lateral thalline margin and thick cover above labia, $0.8-1.3 \mathrm{~mm}$ long, $0.6-1 \mathrm{~mm}$ wide, $0.4-0.6 \mathrm{~mm}$ high; disc concealed; proper margin very thick, labia entire, yellowish gray to white; thalline margin developed laterally and thinly apically, yellowish gray to white. Excipulum entire, completely carbonized (but basal part thin), inner parts with large clusters of crystals; $200-300 \mu \mathrm{m}$ wide, black; laterally covered by corticate algiferous thallus lacking crystals; hypothecium prosoplectenchymatous, $5-15 \mu \mathrm{m}$ high, colorless; hymenium 300-400 $\mu \mathrm{m}$ high, colorless; epithecium indistinct. Paraphyses unbranched; asci fusiform, 200-280 $\times 35-45 \mu \mathrm{m}$. Ascospores 1-2 per ascus, ellipsoid, muriform, $120-180 \times 30-40 \mu \mathrm{m}, 4-5$ times as long as wide, colorless. Secondary chemistry: no substances detected by TLC.

REMARKS-This new species is somewhat similar to Graphis mexicana but has slightly elongated lirellae with a thick thalline margin and a whitish, yet smooth cover different from the thalline margin. Anatomically, the species is characterized by large clusters of crystals filling the space between the lateral hymenium and excipulum, while other species of Graphis have crystals between the excipulum and the algiferous thallus cover. Another superficially similar species is $G$. triphora Nyl., described from Colombia, which agrees chiefly in the morphol- 
ogy of the ascocarps and the crystals present between the hymenium and excipulum but has a laterally carbonized excipulum only and smaller ascospores $(60-70 \times 20-30 \mu \mathrm{m})$; also, the cover on the lirellae is farinose rather than smooth. There are two further species with similar lirellae morphology: Graphis triphoroides (M. Wirth \& Hale) Lücking (Lücking et al., 2008b) differs from G. triphora chiefly in producing stictic acid, while Graphis cleitops Fée has single-spored asci and stictic acid. The latter three somewhat resemble Carbacanthographis species, whereas G. oryzaecarpa externally looks more like a Hemithecium.

ECOLOGY - So far only known from the type collection.

\section{Graphis ovata (Fée) A. Massal. Figure 12F.}

Graphis ovata (Fée) A. Massal., Mem. Lichenogr.: 111. 1853; Opegrapha ovata Fée, Essai Crypt Écorc. 1: 25. 1824. Holotype. Peru, s.col. (G, not seen).

Graphis nuda Staiger, Biblioth. Lichenol. 85: 245. 2002 [nom. inval., ICBN Art. 32, 35-37; non Graphis nuda (H. Magn.) Staiger \& Lücking].

DESCRIPTION-Thallus corticolous, 3-7 cm diam., $50-120 \mu \mathrm{m}$ thick, continuous; surface smooth to slightly uneven, pale greenish gray to white; prothallus absent. Thallus in section with cartilaginous upper cortex and irregular algal layer. Apothecia lirelliform, straight, rarely branched, sessile, lacking thalline margin, 0.5$1.5 \mathrm{~mm}$ long, $0.2-0.4 \mathrm{~mm}$ wide, $0.25-0.3 \mathrm{~mm}$ high; disc concealed; proper margin thick, labia entire, black; thalline margin absent. Excipulum entire, completely carbonized, 50-80 $\mu \mathrm{m}$ wide, black; hypothecium prosoplectenchymatous, 5$10 \mu \mathrm{m}$ high, colorless to pale yellowish; hymenium 120-180 $\mu \mathrm{m}$ high, colorless, clear; epithecium indistinct. Paraphyses unbranched; asci clavate, $100-150 \times 15-20 \mu \mathrm{m}$. Ascospores 8 per ascus, fusiform, with proximal end slightly tapering, both ends with distinct gelatinous cap, transversely 7-11-septate, $40-60 \times 8-13 \mu \mathrm{m}, 4-5$ times as long as wide, colorless. Secondary chemistry: no substances detected by TLC.

REMARKS-Graphis ovata is intermediate between G. adpressa (ascospores 50-70 × 13$15 \mu \mathrm{m}$ ) and $G$. virescens (ascospores 25-45 $\times$ $7-10 \mu \mathrm{m})$, and its ascospores also differ from those of the latter two species in having gelatinous caps at both ends. Graphis nuda was introduced ad interim for this taxon by Staiger (2002), but according to the description given by Müller Argoviensis (1887), G. ovata is conspecif- ic. Graphis nuda sensu Staiger should not be confused with G. nuda (H. Magn.) Staiger \& Lücking, which is a related species but differs in having muriform ascospores (see above).

SPECIMENS SEEN_COSTA RICA. Alajuela: Volcán Tenorio National Park, Pilón Biological Station (Arenal-Tempisque Conservation Area), Tilarán Ridge, $84^{\circ} 59^{\prime} \mathrm{W}, 10^{\circ} 43^{\prime} \mathrm{N}, 700 \mathrm{~m}$, lower montane cloud forest zone, exposed trees and fence posts along pasture, on bark (lower trunk), 16 Mar 2004, Aptroot 60542 (ABL, INB-3967937); 700-900 m, lower montane cloud forest zone, partly disturbed primary forest, on bark (twig), 16 Mar 2004, Lücking $17262 b$ (CR, F, INB4004918, USJ), 17264 (F). Cartago: Tapantí National Park, Tapantí Section, Tapantí Station (La Amistad Pacífico Conservation Area), Talamanca Ridge, $83^{\circ} 47^{\prime} \mathrm{W}, 9^{\circ} 44^{\prime} \mathrm{N}, 1700 \mathrm{~m}$, montane cloud forest zone, primary forest margin along roadside, on trunk at road, 2 Apr 2003, Sipman 51074c (B, INB-3998700). Guanacaste: Volcán Tenorio National Park, Alto Masis Section (Arenal-Tilarán Conservation Area), Tilarán Ridge, $85^{\circ} 00^{\prime} \mathrm{W}, 10^{\circ} 37^{\prime} \mathrm{N}, 950-1000 \mathrm{~m}$, lower montane elfin cloud forest zone, disturbed low elfin forest and secondary vegetation, on bark (lower stem), 17 Mar 2004, Sipman 51927 (B, INB-4055153). Puntarenas: Las Cruces Biological Station and Wilson Botanical Garden near San Vito, 900-1000 m, montane rain forest zone, young planted trees in meadow on hilltop, 10-19 Oct 2004, Sipman 53344 (B, INB3993780); on thin trunk of Terminalia catappa, 10-19 Oct 2004, Sipman 53328 (B, INB-3993740).

\section{Graphis oxyclada Müll. Arg. Figure 12B}

Graphis oxyclada Müll. Arg., Flora 68: 512. 1885. Type. Kenya, Hildebrandt 2540 (G!).

DiAGNOSIS-Thallus corticate, smooth to uneven, white-gray. Lirellae prominent, partly branched, with lateral thalline margin, $1-5 \mathrm{~mm}$ long, $0.2-0.3 \mathrm{~mm}$ broad; labia entire, sharply delimited, jet-black. Excipulum completely carbonized. Hymenium clear. Ascospores 8 per ascus, transversely 9-11-septate, 30-45 × 7$9 \mu \mathrm{m}$, hyaline. Secondary chemistry: no substances detected by TLC.

REMARKS - This species is intermediate between the Graphis scripta group (taxa with completely carbonized excipulum) and the $G$. rhizocola group. Graphis dracenae is anatomically similar but has erumpent, shorter lirellae with less conspicuous lateral thalline margin, whereas $G$. flavens agrees in lirellae morphology, but has larger ascospores.

Specimens Seen-COSTA RICA. Puntarenas: Las Cruces Biological Station and Wilson Botanical Garden near San Vito, 900-1000 m, montane rain forest zone, planted vegetation and disturbed forest, Feb 2000, Lücking 00-17 (F). 
Graphis paradisserpens Sipman \& Lücking, sp. nov. Figure $18 B$.

Sicut Graphis disserpens sed apotheciis emarginatis et ascosporis angustioribus differt. Holotype. COSTA RICA. Puntarenas: Las Tablas Protection Zone, Los Portones Section (La Amistad Pacífico Conservation Area), Talamanca Ridge, $82^{\circ} 48^{\prime} \mathrm{W}, 8^{\circ} 54^{\prime} \mathrm{N}, 1400 \mathrm{~m}$, lower montane rain forest zone, pasture with scattered, small trees, on bark (lower trunk), 28 Jun 2002, Sipman $47989 f$ (INB-3926894, holotype; B, isotype).

Paratypes. COSTA RICA. Cartago: Tapantí National Park, Tapantí Section, Tapantí Station (La Amistad Pacífico Conservation Area), Talamanca Ridge, $83^{\circ} 47^{\prime} \mathrm{W}, 9^{\circ} 45^{\prime} \mathrm{N}, 1400-1600 \mathrm{~m}$, montane rain forest zone, closed primary forest and roadside, on bark (lower stem), 2 Apr 2003, Lücking 16566 (F, INB-4002571). Puntarenas: La Amistad International Park, Altamira Station (La Amistad Pacífico Conservation Area), Talamanca Ridge, $83^{\circ} 00^{\prime} \mathrm{W}, 9^{\circ} 02^{\prime} \mathrm{N}, 1600-1800 \mathrm{~m}$, montane rain forest zone, secondary forest and open secondary vegetation dominated by Cecropia, on bark (lower trunk), 1 Jul 2002, Sipman $48043 g$ (B, INB-3945889). Las Tablas Protection Zone, Cedro Ridge, Las Alturas Station (La Amistad Pacífico Conservation Area), Talamanca Ridge, $82^{\circ} 50^{\prime} \mathrm{W}, 8^{\circ} 57^{\prime} \mathrm{N}, 1500 \mathrm{~m}$, lower montane rain forest zone, reforestation plot (Cedrela odorata) bordering pasture, on bark (lower trunk), 26 Jun 2002, Sipman 47822 (B, INB-3908871).

DESCRIPTION-Thallus corticolous, $2-5 \mathrm{~cm}$ diam., $40-80 \mu \mathrm{m}$ thick, continuous; surface uneven, pale gray to white; prothallus absent. Thallus in section with cartilaginous upper cortex, irregular algal layer and clusters of crystals. Apothecia lirelliform, flexuose, branched and sometimes stellate, erumpent, lacking or with basal thalline margin, $2-8 \mathrm{~mm}$ long, $0.15-0.25 \mathrm{~mm}$ wide, $0.15-0.2 \mathrm{~mm}$ high; disc concealed; proper margin thick, labia striate, black; thalline margin absent or developed basally, pale gray to white. Excipulum crenulate, partially carbonized (upper half and external lateral parts), $70-100 \mu \mathrm{m}$ wide, black, inner and basal parts orange brown; hypothecium prosoplectenchymatous, $10-20 \mu \mathrm{m}$ high, yellowish; hymenium $80-110 \mu \mathrm{m}$ high, colorless, clear; epithecium indistinct. Paraphyses unbranched; asci fusiform, $80-100 \times 15-25 \mu \mathrm{m}$. Ascospores 2-8 per ascus, ellipsoid, submuriform with 5-7 transverse and $0-2$ longitudinal septa per segment, $25-35 \times 10-15 \mu \mathrm{m}, 2-3$ times as long as wide, colorless. Secondary chemistry: no substances detected by TLC.

REMARKS - In spite of extensive search, we could not find a name to accommodate this species. It belongs in the Graphis proserpens aggregate, characterized by striate, apically carbonized lirellae with usually jet-black labia. Among the taxa with small to medium-sized, muriform ascospores, four have either norstictic or stictic acid ( $G$. antillarum, $G$. perstriatula, $G$. parilis, G. subducta Vain.), while the remaining three lack lichen substances but have either distinctly larger ( $G$. platycarpa) or broader ascospores ( $G$. disserpens, $G$. symplecta); in addition, all have a distinct lateral or complete thalline margin. Graphis paradisserpens is morphologically identical with $G$. proserpens, but that species has narrower, transversely septate ascospores.

ECOLOGY--Rather widespread in lower montane to montane rain forest in exposed situations.

Graphis paraserpens Lizano \& Lücking, sp. nov. Figure 21C-D.

Sicut Graphis symplecta sed ascosporis angustioribus differt. Holotype. COSTA RICA. San José: Leonel Oviedo Ecological Reserve (Cordillera Volcánica Central Conservation Area), Central Valley, San José, $84^{\circ} 03^{\prime} \mathrm{W}, 9^{\circ} 56^{\prime} \mathrm{N}, 1200 \mathrm{~m}$, lower montane moist forest zone, old-growth secondary forest, on bark (lower trunk), 4 Nov 2002, Lücking 15667 (UsJ, holotype; F, isotype).

Paratype. COSTA RICA. San José: Same locality, 22 Apr 2003, Lücking 16280 (F).

DESCRIPTION-Thallus corticolous, $2-5 \mathrm{~cm}$ diam., $50-100 \mu \mathrm{m}$ thick, continuous; surface smooth to uneven, pale gray; prothallus absent. Thallus in section with cartilaginous upper cortex, irregular algal layer and clusters of crystals. Apothecia lirelliform, straight to flexuose, partly branched, immersed-erumpent, with thin complete thalline margin, $2-5 \mathrm{~mm}$ long, $0.2-$ $0.3 \mathrm{~mm}$ wide, $0.12-0.18 \mathrm{~mm}$ high; disc concealed; proper margin thick, labia striate, grayish black; thalline margin developed laterally, pale gray to white. Excipulum crenulate, partially carbonized (upper half and external lateral parts), $40-80 \mu \mathrm{m}$ wide, black, inner and basal parts orange brown; laterally covered by corticate algiferous thallus including clusters of crystals; hypothecium prosoplectenchymatous, 5-15 $\mu \mathrm{m}$ high, yellowish; hymenium 70-110 $\mu \mathrm{m}$ high, colorless; epithecium indistinct. Paraphyses unbranched; asci fusiform, $70-100 \times 20-30 \mu \mathrm{m}$. Ascospores 2-6 per ascus, oblong to ellipsoid, muriform, $30-40 \times 9-11 \mu \mathrm{m}, 3-4$ times as long as wide, colorless. Secondary chemistry: no substances detected by TLC.

REMARKS-This well-developed population closely resembles Graphis symplecta but 
differs by its very narrow ascospores. We have seen quite a number of collections of the latter, both from Costa Rica and from the Caribbean, and the ascospores are always very broadly ellipsoid and about $20 \mu \mathrm{m}$ broad on average and less than 2 times as long as wide. We are therefore confident that $G$. paraserpens is a good species, for which apparently no epithet is available.

ECOLOGY - The type collection originates from a secondary university campus vegetation inmidst the mostly deforested, rather dry Central Valley.

\section{Graphis parilis Kremp. Figure 20A-B.}

Graphis parilis Kremp., Flora 59: 422. 1876; Graphina parilis (Kremp.) Müll. Arg., Bull. Soc. Bot. Belg. 32: 152. 1893. Holotype. Brazil, Glaziou 3394 (M, not seen).

Graphis annulata Kremp., Flora 59: 445. 1876. Holotype. Brazil, Glaziou 3388 (M, not seen).

Graphina acromelaena Müll. Arg., Bull. Soc. Bot. Belg. 32: 152. 1893. Holotype. Costa Rica, Tonduz s.n. (G!).

Graphina acrophaea Müll. Arg., Bull. Herb. Boiss. 3: 46. 1895. Holotype. USA (Louisiana), Eckfeldt $751(\mathrm{G} !)$.

DiAgNOSIS-Thallus corticate, smooth to uneven, yellowish gray. Lirellae erumpent, partly branched, with thick lateral thalline margin, 1$5 \mathrm{~mm}$ long, $0.3-0.5 \mathrm{~mm}$ broad; labia striate. Excipulum apically carbonized. Hymenium clear. Ascospores 8 per ascus, muriform, 40-70 $\times$ 15-20 $\mu \mathrm{m}$, hyaline. Secondary chemistry: stictic acid.

REMARKS-Graphina acromelaena was reported as a synonym of $G$. parilis by Wirth and Hale (1963); examination of the type material in $G$ confirmed this view. Synonymy of $G$. acrophaea with $G$. parilis was established by Egan (1990); we have not seen type material of that name.

Specimens SEen-COSTA RICA. The holotype of Graphina acromelaena. Puntarenas: Las Cruces Biological Station and Wilson Botanical Garden near San Vito, 900-1000 m, montane rain forest zone, planted vegetation and disturbed forest, Feb 2000, Lïcking 0012 (F).

\section{Graphis pavoniana Fée. Figure 9E.}

Graphis pavoniana Fée, Essai Crypt Écorc. 1: 40. 1824. Lectotype (fide Staiger, 2002: 246). Unknown locality, s.dat., s.col. (G!).

DiAGNOSIS-Thallus partly ecorticate, unevenfarinose, bluish white-gray, with abundant small crystals. Lirellae erumpent, partly branched, with lateral thalline margin, $1-5 \mathrm{~mm}$ long, $0.1-0.2 \mathrm{~mm}$ broad; labia entire, white pruinose. Excipulum laterally carbonized. Hymenium clear. Ascospores $4-8$ per ascus, transversely 7-17-septate, 30-60 × 7-11 $\mu \mathrm{m}$, hyaline. Secondary chemistry: no substances detected by TLC.

REMARKS-Graphis pavoniana belongs in the $G$. farinulenta aggregate, characterized by elongate lirellae with entire labia and a typically ecorticate, farinose thallus. It somehow resembles G. furcata, but its ascospores are larger, and the thallus of the latter is usually partially corticate. Other similar taxa are farinulenta and G. seminuda, the first having larger ascospores and the second a completely carbonized excipulum.

Graphis pavoniana was also identified by Dodge and his students in the material from Costa Rica at $\mathrm{FH}$, but the specimen is $G$. rimulosa, a taxon that has little in common with G. pavoniana.

SPeCIMENS SEEN-COSTA RICA. Guanacaste: Lomas de Barbudal Biological Reserve, Lomas de Barbudal Station (Tempisque Conservation Area), Río Tempisque Bassin, $85^{\circ} 22^{\prime} \mathrm{W}, 10^{\circ} 30^{\prime} \mathrm{N}, 100 \mathrm{~m}$, lowland to lower montane moist forest zone, disturbed gallery forest and forest remnants, on bark (lower trunk), 29 Mar 2003, Trest $1352 b$ (GZU). Palo Verde National Park (Tempisque Conservation Area), 0 $100 \mathrm{~m}, 10^{\circ} 21^{\prime} \mathrm{N}, 85^{\circ} 21^{\prime} \mathrm{W}, 28$ Mar 2003, López 4331 (INB), 465 (INB), 467 (INB), 468 (INB), 485 (INB); Palo Verde Station (Tempisque Conservation Area), Río Tempisque Bassin, 85 $21^{\prime} \mathrm{W}, 10^{\circ} 21^{\prime} \mathrm{N}, 10-50 \mathrm{~m}$, lowland to lower montane moist forest zone, disturbed primary forest remnants and open secondary forest, on bark (lower trunk), 27 Mar 2003, Buck 43889 (CR, NY). Heredia: Instituto Nacional de Biodiversidad (INBio) campus (Cordillera Volcánica Central Conservation Area), Central Valley, Santo Domingo, $84^{\circ} 05^{\prime} \mathrm{W}$, $9^{\circ} 59^{\prime} \mathrm{N}, 1150 \mathrm{~m}$, lower montane moist forest zone, planted trees and secondary forest on institute campus, on bark (lower stem), 14 Mar 2004, Sipman 51754 (B, INB), 51755 (B, INB). Limón: Gandoca-Manzanillo Wildlife Refuge, Manzanillo Section (La Amistad Caribe Conservation Area), Manzanillo, $82^{\circ} 53^{\prime} \mathrm{W}$, $9^{\circ} 38^{\prime} \mathrm{N}$, sea level, lowland coastal moist forest zone, disturbed coastal vegetation with Cocos nucifera, Coccoloba uvifera, on bark (lower stem), 11 Mar 2004, Lücking $17106 b$ (CR, F). Puntarenas: Mellizas, border to Panama (La Amistad Pacífico Conservation Area), 1400-1500 m, 8 $53^{\prime} \mathrm{N}, 82^{\circ} 46^{\prime} \mathrm{W}, 28$ Aug 2002, Navarro 5278 g (INB). San José: Universidad de Costa Rica Campus (Cordillera Volcánica Central Conservation Area), Central Valley, San José, $84^{\circ} 03^{\prime} \mathrm{W}$, $9^{\circ} 56^{\prime} \mathrm{N}, 1200 \mathrm{~m}$, lower montane moist forest zone, planted trees on campus, on bark (lower trunk), 20 Jun 2002, Lücking 15034c (F).

\section{Graphis perstriatula Nyl. Figure 20C-D.}

Graphis perstriatula Nyl., Bull. Soc. Linn. Normandie, Ser. 2, 7: 176. 1873. Lectotype (fide Awasthi 
\& Singh, annotation label in 1974). Andaman Islands, Kur- s.ru. (H-Nyl 7779!).

Graphis acuminata Vain., Ann. Acad. Sci. Fenn., Ser. A, 6: 147. 1915. Holotype. St. Jan, Raunkiaer 437 (TUR-Vainio 27243!).

Graphis gracilescens Vain., Ann. Acad. Sci. Fenn., Ser. A, 15(6): 203. 1921. Holotype. Mariana Islands, McGregor 604 (TUR-Vainio 27238!).

Graphina sulcata Fink, Mycologia 19: 217. 1927. Holotype. Puerto Rico, Fink 659 (MICH).

Graphis poly'schizans Vain. [nom. inval., ICBN Art. 32, 35-37]. Original material. Cuba, Ekman 5 (TUR-Vainio 27169!).

DIAGNOSIS-Thallus corticate, smooth to uneven, yellowish gray. Lirellae erumpent, partly branched, with basal thalline margin, 1-5 mm long, 0.1-0.2 mm broad; labia striate. Excipulum apically carbonized. Hymenium clear. Ascospores 2-4 per ascus, muriform, $20-40 \times 11-15 \mu \mathrm{m}$, hyaline. Secondary chemistry: norstictic acid.

REMARKS-Graphis perstriatula is very similar to $G$. antillarum, sharing the immersed-erumpent lirellae with lateral thalline margin, striate labia, apically carbonized excipulum, muriform ascospores, and norstictic acid. Based on the material available so far, both taxa can be distinguished by their ascospore sizes $(20-40 \times 10-20 \mu \mathrm{m}$ versus $40-60 \times 20-25 \mu \mathrm{m}$ on average), but there is some degree of overlap, and further collections may show that both are conspecific.

Specimens SeEn-COSTA RICA. Alajuela: La Palma de San Ramón, 1250 m, 22 Oct 1929, Brenes 98 (FH). Guanacaste: Monte Alto, Mirador Section (Tempisque Conservation Area), 700-750 m, 10 $00^{\prime} \mathrm{N}$, $85^{\circ} 23^{\prime} \mathrm{W}, 6$ Jun 2003, Chaves 589 (INB). Novasa Wind Power Project (Arenal-Tilarán Conservation Area), Tilarán Ridge, Tierras Morenas, $85^{\circ} 01^{\prime} \mathrm{W}, 10^{\circ} 38^{\prime} \mathrm{N}$, $750 \mathrm{~m}$, lower montane moist forest zone, exposed trees and fence posts along pasture, on wood (fence post), 23 Mar 2004, Lücking 17707 (F. INB). Tropica Verde Reforestation Project (Tempisque Conservation Area), Nicoya Peninsula, $85^{\circ} 23^{\prime} \mathrm{W}, 10^{\circ} 01^{\prime} \mathrm{N}, 850-900 \mathrm{~m}$, lowland to lower montane moist forest zone, exposed trees and fence posts along pasture, on bark (lower trunk), 22 Mar 2004, Lücking 17625 (F).

\section{Graphis phaeospora Vain. Figure $24 \mathrm{H}$.}

Graphis phaeospora Vain., Acta Soc. Fauna Fl. Fenn. 7: 97. 1890. Holotype. Brazil, Vainio S.n. (TUR-Vainio 27166!; Vainio, Lich. Bras. Exs. 682).

Graphis subcinerea Staiger, Biblioth. Lichenol. 85: 258. 2002 [nom. inval., ICBN Art. 32, 35-37].

DiAGNOSIS - Thallus corticate, smooth to uneven, white-gray. Lirellae prominent, partly branched, with (apically thin) complete thalline cover, $1-5 \mathrm{~mm}$ long, $0.4-0.6 \mathrm{~mm}$ broad; labia entire (to striate). Excipulum completely carbon- ized. Hymenium inspersed (type B). Ascospores 2-4 per ascus, muriform, $110-130 \times 25-35 \mu \mathrm{m}$, hyaline. Secondary chemistry: no substances detected by TLC.

REMARKS-While the absence or presence of striate labia, in correlation with other characters, appears to be a valid feature to distinguish many representatives of the genus Graphis, species cannot be separated on account of this character alone. The best-documented example is G. chrysocarpa, which usually has strongly striate lirellae, but collections with solely entire labia are frequently found; all other characters are identical. In this paper, we describe several new taxa in the $G$. cinerea aggregate, which belongs in the $G$. acharii group and hence is closely related to $G$. chrysocarpa and allies (Staiger, 2002). Depending on whether having entire or striate labia, one could distinguish up to 12 different species in that aggregate. However, in two instances, that is, $G$. argentata and $G$. subflexibilis, we could establish specimens with entire and striate labia as belonging to the same species. We therefore assume that it is a common feature of species of this group to produce persistent first-generation lirellae with entire labia that eventually become striate in the second year or later. Following this argument, $G$. subcinerea Staiger ad interim (Staiger, 2002), which fits some of our collections, is here considered a synonym of $G$. phaeospora, which differs only in having striate versus entire lirellae, while they are otherwise identical.

Graphis phaeospora was listed as a synonym of G. inturgescens by Wirth and Hale (1963) but differs by its strongly inspersed hymenium, among other details. The species might be confused with $G$. mirabilis, but the latter has an apically and basally carbonized excipulum and single-spored asci.

Specimens Seen - COSTA RICA. Puntarenas: Mellizas, border to Panama (La Amistad Pacífico Conservation Area), $1400-1500 \mathrm{~m}, 8^{\circ} 53^{\prime} \mathrm{N}, 82^{\circ} 46^{\prime} \mathrm{W}, 28$ Aug 2002, Chaves $10 \mathrm{~g}$ (INB-3760224).

Graphis pittieri Lücking, Umaña, Sipman \& Chaves, sp. nov. Figure 13F.

Sicut Graphis adpressa sed ascosporis cinereo-fuscis differt. Holotype. COSTA RICA. Puntarenas: La Amistad International Park, Altamira Station (La Amistad Pacífico Conservation Area), Talamanca Ridge, $83^{\circ} 00^{\prime} \mathrm{W}, 9^{\circ} 02^{\prime} \mathrm{N}, 1600-1800 \mathrm{~m}$, montane rain forest zone, secondary forest and open secondary vegetation dominated by Cecropia, on bark (branch), 1 Jul 2002, Lïcking 15247 g (INB-3976219, holotype; F, isotype). 
Paratypes. COSTA RICA. Cartago: Tapantí National Park, $\mathrm{km} 68$ on road 2 from Cartago to San Isidro, $83^{\circ} 51^{\prime} \mathrm{W}, 9^{\circ} 40^{\prime} \mathrm{N}, 2700 \mathrm{~m}$, on twigs in Puya bog, 25 Mar 2005, Aptroot 60981 (ABL, INB4021819).

DESCRIPTION---Thallus corticolous, $1-3 \mathrm{~cm}$ diam., $50-100 \mu \mathrm{m}$ thick, continuous; surface smooth to uneven, pale greenish gray; prothallus absent. Thallus in section with cartilaginous upper cortex and irregular algal layer. Apothecia lirelliform, straight to flexuose, unbranched, sessile, lacking thalline margin, $0.5-1.5 \mathrm{~mm}$ long, $0.2-0.3 \mathrm{~mm}$ wide, $0.25-0.35 \mathrm{~mm}$ high; disc concealed; proper margin thick, labia entire, grayish black to black. Excipulum entire, completely carbonized, 40-100 $\mu \mathrm{m}$ wide, black; hypothecium prosoplectenchymatous, $10-20 \mu \mathrm{m}$ high, colorless to pale yellowish; hymenium 150$250 \mu \mathrm{m}$ high, colorless, clear; epithecium indistinct. Paraphyses unbranched; asci clavate, 130$170 \mu \mathrm{m}$ long, $18-25 \mu \mathrm{m}$ wide. Ascospores 8 per ascus, oblong, transversely 9-11-septate, 50-65 $\times 11-14 \mu \mathrm{m}, 4-5$ times as long as wide, grayish brown (but reacting I+ violet). Secondary chemistry: no substances detected by TLC.

REMARKS-Based on its lirellae morphology, Graphis pitteri belongs in the G. nuda group but differs from the other species by its pale graybrown ascospores. Most closely related is $G$. adpressa, which has similarly sized but colorless ascospores. Pale gray-brown ascospores are sometimes found in species of Graphis with otherwise colorless ascospores and usually believed to be postmature; in the case of G. pittieri, however, all ascospores are grayish brown and clearly mature and turgescent, similar to the ascospores found in G. elegans.

The new species seemingly links the Graphis nuda group to Thecographa prosiliens (Mont. \& Bosch) A. Massal. [ $\equiv$ Phaeographina prosiliens (Mont. \& Bosch) Müll. Arg; see Lücking et al., 2007c], which also has sessile, Melaspilea-like lirellae. However, in the latter, the lirellae are much larger and elongate, the thallus is green (untypical for Graphis), the hymenium is inspersed, and the ascospores are I+ vine red. In spite of its lirellae being somewhat similar to those of the Graphis nuda group, this taxon is not related to Graphis, as suggested by Staiger (2002), but closer to Phaeographis and its relatives, in particular Thecaria and Platygramme. Reexamination of the original publication of Phaeographina revealed that this generic name is illegitimate, and therefore Lücking et al. (2007c) reestablished the name Thecographa prosiliens for that taxon.

ECOLOGY - Apparently a montane rain forest species.

\section{Graphis plagiocarpa Fée. Figure 17A.}

Graphis plagiocarpa Fée, Essai Crypt. Écorc.: 38. 1824; Isotype. Unknown locality, unknown collector (G!).

Graphina lumbschii var. deficiens A. W. Archer, Mycotaxon 77: 167. 2001; Graphis lumbschii var. deficiens A. W. Archer, Telopea 11: 73. 2005. Holotype. Australia, Streimann 45427 (CANB, photograph seen).

DiAGNOSIS - Thallus corticate, smooth to uneven, green-gray. Lirellae sessile, unbranched, with thick lateral thalline margin, $0.5-1 \mathrm{~mm}$ long, $0.3-0.5 \mathrm{~mm}$ broad; labia entire. Excipulum completely carbonized. Hymenium clear. Ascospores 4-8 per ascus, terminally muriform with 15-21 transverse septa and 1-2 longitudinal septa per segment in terminal segments, 80-120 $\times$ 8-12 $\mu \mathrm{m}$, hyaline. Secondary chemistry: no substances detected by TLC.

REMARKS-Graphis plagiocarpa is known to us from a number of collections throughout the Neotropics and represents the most common and widespread of the G. dussii aggregate, comprising species with short, prominent to sessile lirellae featuring a thick lateral thalline margin. The species differ in ascospore type and secondary chemistry (see under G. cleistoblephara). Graphis lumbschii var. deficiens is identical with $G$. plagiocarpa (Archer, 2007).

SpeCIMENS SEEN-COSTA RICA. Alajuela: Alto del Mondongo del San Ramón, 800 m, 9 Jan 1930, Brenes $322(\mathrm{FH})$.

\section{Graphis platycarpa Eschw. Figure 19A-B.}

Graphis platycarpa Eschw. in Martius, Fl. Bras. 1: 74. 1833. Type. Brazil, Martius s.n. (M, not seen). Graphis sophistica Nyl., Ann. Sci. Nat., Bot., Sér. 4, 19: 359. 1863; Graphina sophistica (Nyl.) Müll. Arg., Flora 63: 23. 1880. Lectotype (fide Archer, annotation label in 2001). Colombia, Lindig 2726 (H-Nyl 7379!).

Diagnosis-Thallus corticate, smooth to uneven, white-gray. Lirellae erumpent, rarely branched, with (apically thin) complete thalline cover, $1-5 \mathrm{~mm}$ long, $0.2-0.3 \mathrm{~mm}$ broad; labia striate. Excipulum apically carbonized. Hymenium clear. Ascospores 8 per ascus, muriform, 50$70 \times 14-21 \mu \mathrm{m}$, hyaline. Secondary chemistry: no substances detected by TLC. 
REMARKS - This species chiefly agrees with Graphis parilis, except for the absence of stictic acid. Previously reported for Costa Rica by Müller Argoviensis (1891, 1893a) and also listed for Cocos Island (Elix \& McCarthy, 1998). The synonymy of $G$. sophistica with $G$. platycarpa was pointed out to us by A. W. Archer (pers. comm., 2007).

Pittier and Durand's Plantae Costaricenses Exsiccatae no. 6174 was published as Graphina sophistica, but the duplicate in US is a young Graphis perstriatula. The material listed under the name Graphina sophistica from Costa Rica housed in FH is Hentithecium chlorocarpum (Fée) Trevis.

Specimens SeEN-COSTA RICA. Guanacaste: Lomas de Barbudal Biological Reserve, Lomas de Barbudal Station (Tempisque Conservation Area), Río Tempisque Bassin, $85^{\circ} 22^{\prime} \mathrm{W}, 10^{\circ} 30^{\prime} \mathrm{N}, 100 \mathrm{~m}$, lowland to lower montane moist forest zone, disturbed gallery forest and forest remnants, on bark (lower stem), 29 Mar 2003, Lücking 16118e (F). Monte Alto Forest Reserve, Cerro Romo (Tempisque Conservation Area), Nicoya Peninsula, $85^{\circ} 24^{\prime} \mathrm{W}, 10^{\circ} 00^{\prime} \mathrm{N}, 750$ $900 \mathrm{~m}$, lowland to lower montane moist forest zone, forest regrowth along pasture, on bark (lower trunk), 22 Mar 2004, Lücking 17583 (CR, F, INB, USJ).

\section{Graphis plurispora (Redinger) Lücking \&} Chaves, comb. nov. Figure 22B.

Graphina pseudosophistica var. plurispora Redinger, Ark. Bot. 26A(1): 36. 1933; Graphina plurispora (Redinger) Wirth \& Hale, Smiths. Contr. Bot. 40: 41. 1978. Lectotype (fide Wirth \& Hale, 1978: 41): Brazil, Malme 998 (s 6508!).

Diagnosis-Thallus corticate, smooth to uneven, green-gray. Lirellae erumpent, partly branched, with lateral thalline margin, $2-5 \mathrm{~mm}$ long, $0.2-0.3 \mathrm{~mm}$ broad; labia striate. Excipulum completely carbonized. Hymenium clear. Ascospores 2-6 per ascus, muriform, 30-60 × 10$15 \mu \mathrm{m}$, hyaline. Secondary chemistry: no substances detected by TLC.

REMARKS-This widespread species belongs in the Graphis duplicata group and can be distinguished by its completely carbonized excipulum and medium-sized, muriform ascospores. The lirellae are often covered by a thin thalline layer (cortex) that easily flakes off and exposes the black lirellae surface. Graphis multisulcata differs chiefly in the broader ascospores $(15-23 \mu \mathrm{m})$, and the thalline cover of the lirellae does not flake off.

Specimens SEEN-COSTA RICA. Guanacaste: Monte Alto Forest Reserve, Monte Alto Bio- logical Station (Tempisque Conservation Area), Nicoya Peninsula, $85^{\circ} 24^{\prime} \mathrm{W}, 10^{\circ} 02^{\prime} \mathrm{N}, 450-550 \mathrm{~m}$, lowland to lower montane moist forest zone, disturbed primary and old-growth secondary forest, on bark (lower trunk), 21 Mar 2004, Lücking $17527 b$ (CR, F, INB-4017351, USJ). Heredia: Santo Domingo, Santa Rosa, INBio compound, $84^{\circ} 06^{\prime} \mathrm{W}, 9^{\circ} 58^{\prime} \mathrm{N}$, $1150 \mathrm{~m}$, lower montane moist forest zone, young trunks in garden, 12 Mar 2004, Sipman 51753 (B, INB-4056188). Puntarenas: Las Cruces Biological Station and Wilson Botanical Garden near San Vito, 900-1000 m, montane rain forest zone, planted vegetation and disturbed forest, 10-24 Oct 2004, Lücking 18014 (F), $18038 a$ (F); 16 Oct 2004, Pérez Pérez CR2021 (INB).

\section{Graphis proserpens Vain. Figure 8E.}

Graphis proserpens Vain., Bot. Tidsskr. 29: 132. 1909; G. disserpens Vain., Acta Soc. Fauna Fl. Fenn. 7: 123. 1890 [nom. illeg., ICBN Art. 53.1; non $G$. disserpens Nyl.]. Holotype. Brazil, Vainio s.n. (TUR-Vainio 27577A!; Vainio, Lich. Bras. Exs. 1091).

Graphis sikkimensis Nagarkar \& Patw., Biovigyanam 8: 129. 1982. Holotype. India (not seen).

DiAGNOSIS-Thallus corticate, smooth to uneven, white-gray. Lirellae erumpent, richly branched, with basal thalline margin, $1-5 \mathrm{~mm}$ long, $0.2-0.4 \mathrm{~mm}$ broad; labia striate. Excipulum apically (to peripherally) carbonized. Hymenium clear. Ascospores 8 per ascus, transversely 7-11septate, $20-40 \times 6-9 \mu \mathrm{m}$, hyaline. Secondary chemistry: no substances detected by TLC.

REMARKS-One of the most common and widespread species of the genus. The lirellae are slender and much branched and often radiating. Most similar is G. chlorotica, which has somewhat broader lirellae with lateral thalline margin. Another close relative is the newly described $G$. paradisserpens, which cannot be distinguished from $G$. proserpens morphologically but has muriform ascospores. Graphis sikkimensis represents a typical $G$. proserpens, according to the data provided by Adawadkar and Makhija (2007).

SPECIMENS SEEN_COSTA RICA. Alajuela: Volcán Tenorio National Park, Pilón Biological Station (Arenal-Tempisque Conservation Area), Tilarán Ridge, $84^{\circ} 59^{\prime} \mathrm{W}, 10^{\circ} 43^{\prime} \mathrm{N}, 700 \mathrm{~m}$, lower montane cloud forest zone, exposed trees and fence posts along pasture, on bark (lower trunk), 15 Mar 2004, Lücking 17204 (F); 16 Mar 2004, Aptroot 60570 (ABL, INB). Cartago: Barbilla National Park (La Amistad Caribe Conservation Area), main trail to Río Danta. 400 $500 \mathrm{~m}, 9^{\circ} 59^{\prime} \mathrm{N}, 83^{\circ} 29^{\prime} \mathrm{W}, 16$ Feb 2003, Chaves 378 (INB). Limón: Gandoca-Manzanillo Wildlife Refuge, Manzanillo Section (La Amistad Caribe Conservation Area), Manzanillo, $82^{\circ} 53^{\prime} \mathrm{W}, 9^{\circ} 38^{\prime} \mathrm{N}$, sea level, lowland coastal moist forest zone, disturbed coastal 
vegetation with Cocos nucifera, Coccoloba uvifera, on bark (lower trunk), 11 Mar 2004, Aptroot 60326 (ABL. INB). Limón: Hitoy Cerere Biological Reserve, Hitoy Cerere Biological Station (La Amistad Caribe Conservation Area), Talamanca Ridge, $83^{\circ} 02^{\prime} \mathrm{W}, 9^{\circ} 40^{\prime} \mathrm{N}$, $150-300 \mathrm{~m}$, lowland to lower montane rain forest zone, partly disturbed primary forest, on bark (lower trunk), 10 Mar 2004, Lïcking 17026e (F). Puntarenas: Isla del Caño Biological Reserve (Osa Conservation Area), $0-100 \mathrm{~m}, 8^{\circ} 42^{\prime} \mathrm{N}, 83^{\circ} 52^{\prime} \mathrm{W}, 25 \mathrm{Aug}$ 2003, Navarro 7109 (INB). La Amistad International Park, Altamira Station (La Amistad Pacífico Conservation Area), Talamanca Ridge, $83^{\circ} 00^{\prime} \mathrm{W}, 9^{\circ} 02^{\prime} \mathrm{N}$, $1500-1600 \mathrm{~m}$. montane rain forest zone, disturbed primary forest and secondary vegetation dominated by Cecropia, on bark (lower stem), 30 Jun 2002, Lücking $15214 a$ (F. INB, USJ), 15225d (ESS, F, INB): on bark (lower trunk), 30 Jun 2002. Sipman 48027e (B, INB); $83^{\circ} 00^{\prime} \mathrm{W}, 9^{\circ} 02^{\prime} \mathrm{N}, 1600-1800 \mathrm{~m}$. montane rain forest zone, secondary forest and open secondary vegetation dominated by Cecropia. on bark (lower trunk), 1 Jul 2002, Lücking 15253 a (F. INB). $15260 b$ (F), $15264 b$ (INB), $15270 c$ (CR, F, INB. USJ). Las Tablas Protection Zone, Los Portones Section (La Amistad Pacífico Conservation Area). Talamanca Ridge, $82^{\circ} 48^{\prime} \mathrm{W}, 8^{\circ} 54^{\prime} \mathrm{N}, 1400 \mathrm{~m}$, lower montane rain forest zone, pasture with scattered, small trees, on bark (lower trunk). 28 Jun 2002 , Lïcking $15131 f$ (F. INB).

Graphis pseudocinerea Lücking \& Umaña, sp. nov. Figure $24 \mathrm{~A}$.

Sicut Graphis cinerea sed ascosporis minoribus differt. Holotype. COSTA RICA. Puntarenas: La Amistad International Park, Altamira Station (La Amistad Pacífico Conservation Area). Talamanca Ridge, $83^{\circ} 00^{\prime} \mathrm{W}, 9^{\circ} 02^{\prime} \mathrm{N} .1450 \mathrm{~m}$. lower montane rain forest zone. planted trees on and adjacent to campground. on bark (lower stem), 30 Jun 2002. Lücking 15235a (F. holotype)

Paratypes. COSTA RICA. Puntarenas: Zona Protectora Las Tablas, Mellizas (La Amistad Pacífico Conservation Area), 1400-1500 m, $8^{\circ} 53^{\prime} \mathrm{N} .82^{\circ} 46^{\prime} \mathrm{W} .28$ Aug 2002. Chaves $14 \mathrm{e}$ (INB-3760264).

DESCRIPTION-Thallus corticolous, $2-5 \mathrm{~cm}$ diam., 50-150 $\mu \mathrm{m}$ thick, continuous; surface uneven to weakly verrucose, pale gray to white: prothallus absent. Thallus in section with cartilaginous upper cortex, irregular algal layer and clusters of crystals. Apothecia lirelliform, flexuose, rarely branched, prominent. with thin complete thalline margin, $1-5 \mathrm{~mm}$ long. $0.3-$ $0.5 \mathrm{~mm}$ wide, $0.25-0.35 \mathrm{~mm}$ high: disc concealed; proper margin very thick, labia striate. grayish black to gray; thalline margin laterally thick, pale gray to white. apically thin (cortex). gray. Excipulum crenulate, completely carbonized, 50-100 $\mu \mathrm{m}$ wide. black; laterally covered by corticate algiferous thallus including clusters of crystals; hypothecium prosoplectenchymatous, 5-15 $\mu \mathrm{m}$ high, colorless: hymenium 130 $170 \mu \mathrm{m}$ high, colorless, inspersed (type B): epithecium indistinct. Paraphyses unbranched: asci ellipsoid, 100-140 × 25-35 $\mu \mathrm{m}$. Ascospores 4.8 per ascus, oblong to ellipsoid, muriform, 50 $65 \times 9-12 \mu \mathrm{m}, 56$ times as long as wide, colorless. Secondary chemistry: no substances detected by TLC.

REMARKS-Graphis pseudocinerea is another new species in the $G$. cinerea aggregate. It shares the muriform ascospores with the latter and with G. argentata but differs clearly in the ascospores being rather short. Graphis plurispora is similar in ascospore dimensions and morphology but can be readily distinguished by its clear hymenium.

ECOLOGY-Like the other species of this aggregate, Graphis pseudocinerea seems to be restricted to partly exposed microsites in lower montane to montane rain forests with high amounts of precipitation.

\section{Graphis pseudoserpens Chaves \& Lücking. sp.} nov. Figure $18 \mathrm{C}-\mathrm{D}$.

Sicut Graphis puiggarii sed ascosporis maioribus differt. Holotype. COSTA RICA. Guanacaste: Palo Verde National Park. Palo Verde Station (Tempisque Conservation Area). Río Tempisque Bassin. $130 \mathrm{~km}$ WNW of San José and $30 \mathrm{~km}$ SSW of Bagaces. $85^{\prime} 21^{\prime} \mathrm{W} .10^{2} 21^{\prime} \mathrm{N} .10-50 \mathrm{~m}$. lowland to lower montane moist forest zone. disturbed primary forest remnants and open secondary forest, on bark (lower trunk). 27 Mar 2003. Chaves 466 (NB-3773694: CR. isotype).

Paratypes. COSTA RICA. Guanacaste: Along Rio Liberia W of Liberia on road to Buenos Aires. 100 m. 4 Feb 1930. Dodge \& Thomas 8324 (FH). Puntarenas: Las Cruces Biological Station. San Vito de Coto Brus. 82 $58^{\prime} \mathrm{W} .8^{\circ} 47^{\prime}$ N. $1200 \mathrm{~m}$. young planted trees in meadow on hilltop. on thin trunk of Tabebuia chrisantha. 10-19 Oct 2004. Sipman 53374 (B. INB-3993878).

DESCRIPTION-Thallus corticolous. $2-5 \mathrm{~cm}$ diam., 50-100 $\mu \mathrm{m}$ thick. continuous; surface smooth to uneven, pale gray to white: prothallus absent. Thallus in section with cartilaginous upper cortex and irregular algal layer. Apothecia lirelliform. flexuose, partly branched. erumpent. with lateral thalline margin. $1-3 \mathrm{~mm}$ long. $0.15-0.25 \mathrm{~mm}$ wide. $0.12-0.16 \mathrm{~mm}$ high: disc concealed: proper margin distinct. labia striate. black: thalline margin developed laterally. pale gray to white. Excipulum crenulate. laterally carbonized, 20-50 $\mu \mathrm{m}$ wide. black. basal parts yellowish brown: laterally covered 
by corticate algiferous thallus including clusters of crystals; hypothecium prosoplectenchymatous, 5-10 $\mu \mathrm{m}$ high, colorless to pale yellowish; hymenium 100-130 $\mu \mathrm{m}$ high, colorless, clear; epithecium indistinct. Paraphyses unbranched; asci clavate, $90-120 \times 20-30 \mu \mathrm{m}$. Ascospores 8 per ascus, ellipsoid, muriform, 35-60 $\times 10$ $15 \mu \mathrm{m}, 3-5$ times as long as wide, colorless. Secondary chemistry: no substances detected by TLC.

REMARKS-This new species belongs in a rather small group of taxa with striate labia, laterally carbonized excipulum, clear hymenium, and muriform ascospores. So far, only five names were found (among the more than 600 types studied) that belong in this group: Graphis elongata Vain. (norstictic acid), G. dichotoma Müll. Arg. $(=G$. elongatoradians Fink; ascospores 20-40 $\mu \mathrm{m}$ long; lirellae very elongate and radiately branched), and Graphina puiggarii Müll. Arg. (= G. endoschiza Müll. Arg.; ascospores $25-35 \mu \mathrm{m}$ long, lirellae with thin complete thalline margin). Graphis pseudoserpens cannot be identified with any of these. Morphologically similar are some species of the $G$. proserpens aggregate, that is, G. platycarpa, G. symplecta, and $G$. paraserpens, but these can be distinguished by their apically carbonized excipulum and either larger or smaller and broader ascospores. The Costa Rican material housed in $\mathrm{FH}$ and identified as Graphina dichotoma Müll. Arg. (FH) belongs to G. pseudoserpens.

ECOLOGY-Found in rather dry forest in exposed situations.

Graphis puiggarii (Müll. Arg.) Lücking, comb. nov. Figure $21 \mathrm{~A}$.

Graphina puiggarii Müll. Arg., Flora 63: 22. 1880. Holotype. Brazil, Puiggari 506 (G!)

Graphina endoschiza Müll. Arg., Rev. Mycol. 10: 119. 1888. Holotype. Paraguay, Balansa s.n. (G!; Balansa, Lich. Paraguayenses 179).

DiAGNOSIS-Thallus corticate, smooth to uneven, gray. Lirellae erumpent, rarely branched, with (apically thin) complete thalline cover, 1$3 \mathrm{~mm}$ long, $0.2-0.4 \mathrm{~mm}$ broad; labia striate. Excipulum laterally carbonized. Hymenium clear. Ascospores 4-8 per ascus, muriform, 25$35 \times 8-12 \mu \mathrm{m}$, hyaline. Secondary chemistry: no substances detected by TLC.

REMARKS-This species resembles Graphis multisulcata, which differs mainly by its completely carbonized excipulum, whereas the newly described $G$. pseudoserpens has larger ascospores.
Material partly belonging to $G$. puiggarii was found in FH identified as $G$. conferta Zenker and $G$. duplicata. One of the collections cited below (Aptroot 60402) is saxicolous.

Graphis (Graphina) puiggarii was recently established as lectotype of the genus Graphina, which makes the latter a synonym of Graphis (Lücking et al., 2007c).

Specimens Seen-COSTA RICA. Alajuela: Rio Grande de Tárcoles, San Isidro de San Ramón, 800 m, 25 Feb 1930, Brenes 530 (FH). Guanacaste: Roadsides S of Liberia, 100 m, 16 Jan 1930, Dodge \& Thomas s.n. (FH). Volcán Tenorio National Park, $25 \mathrm{~km}$ NNW of Tilaran, $84^{\circ} 59 \mathrm{~W}, 10^{\circ} 43^{\prime} \mathrm{N}, 700 \mathrm{~m}$, on volcanic boulders in meadow along access road to station near Bijagua, 15 Mar 2004, Aptroot 60402 (ABL, INB).

\section{Graphis rhizocola (Fée) Lücking \& Chaves, comb. nov. Figure 15A-D.}

Opegrapha rhizocola Fée, Essai Crypt. Écorc.: 33. 1824. Type. South America, unknown locality (G, not seen).

Graphis cooperta Zenk. in Goebel \& Kunze, Pharmazeut. Waarenkunde 1: 187. 1829. Type. Unknown locality (not seen).

Graphis anguilliformis Taylor, London J. Bot. 6: 152. 1847. Holotype. St. Vincent, s.col. (FHTaylor!).

Graphis serpens Fée, Bull. Soc. Bot. France 21: 27. 1874. Holotype. Brazil, Glaziou 6279 (G!).

Graphis anguillaeformis var. infecunda Vain., nom. herb. Original material. Trinidad, Thaxter 92 (TUR-Vainio 27529!).

Graphis illota var. leopoldensis Redinger, Ark. Bot. 27A(3): 29. 1935. Holotype. Brazil, Malme 634 (S 6501!).

DiAGNOSIS-Thallus corticate, smooth to uneven, green-gray. Lirellae prominent, partly branched, with (apically thin) complete thalline cover lacking crystals, 2-10 mm long, 0.4$0.6 \mathrm{~mm}$ broad; labia entire (very rarely pseudostriate). Excipulum completely carbonized. Hymenium clear. Ascospores 2-8 per ascus, transversely 19-25-septate, 70-130 × 11-20 $\mathrm{m}$, hyaline, I+ violet-blue, ends usually shortly caudate and thin-walled, with gelatinous caps. Secondary chemistry: no substances detected by TLC.

REMARKS-Staiger (2002) discussed this taxon under the younger name Graphis serpens Fée but recognized $G$. anguilliformis as a possible older epithet available. As a matter of fact, there are two even earlier names that represent this rather widespread and common species, that is, Opegrapha rhizocola Fée and Graphis cooperta Zenker (Wirth \& Hale, 1978). We have not yet 
seen original material of these taxa, but according to the statements by Fée (1824) and Müller Argoviensis (1887), there can be little doubt that all are conspecific.

The original material of the unpublished name Graphis anguillaeformis var. infecunda agrees with $G$. rhizocola in all aspects, except that the lirellae appear partially striate. We have found several specimens of this morph in Costa Rica (Chaves 2544, Lücking 17226, 17303a), but since all other characters, including thallus morphology and ecology, are identical, we consider this an example of a taxon that usually retains entire labia but eventually may form crenulate to striate labia in parts of the thallus. Also, the striation in these specimens is restricted to the outermost part of the excipulum and the covering thallus and does not seem to originate from the formation of new hymenia ("pseudostriate").

Dodge and his students had a very diffuse idea of this species (as Graphis anguilliformis) since the material representing that species housed in FH was variously identified as $G$. candidata Nyl. (now in Carbacanthographis), G. conferta Zenker, G. illinata (a species with muriform ascospores), and G. rufula Mont. (now placed in Fissurina).

Specimens Seen-COSTA RICA. Alajuela: Arenal National Park (Arenal Conservation Area), Tucanes trail, $600-700 \mathrm{~m}, 10^{\circ} 26^{\prime} \mathrm{N}, 84^{\circ} 43^{\prime} \mathrm{W}$, primary and secondary forest, 10 Jan 2004, Chaves 1151 (INB), 1152 (INB), 1156 (INB), 1157 (INB). Bijagua, Alto Los Brenes Section (Arenal Conservation Area), $700-$ $800 \mathrm{~m}, 10^{\circ} 44^{\prime} \mathrm{N}, 85^{\circ} 02^{\prime} \mathrm{W}, 7$ Aug 2003, Chaves 951 (INB), 955 (INB). Grecia Forest Reserve, Bosque del Niño (Cordillera Volcánica Central Conservation Area), $1800-1900 \mathrm{~m}, 10^{\circ} 09^{\prime} \mathrm{N}, 84^{\circ} 14^{\prime} \mathrm{W}, 8$ Jun 2005 , Chaves 2425 (INB). La Palma de San Ramón, 1100 m, 8 Oct 1929, Brenes 28 (FH), 29 (FH). Miravalles Protection Zone, Zapote Section (Arenal Conservation Area), $800-900 \mathrm{~m}, 10^{\circ} 44^{\prime} \mathrm{N}, 85^{\circ} 06^{\prime} \mathrm{W}, 15$ Jan 2005 , López 6553 (INB), 6564 (INB). Tenorio Protection Zone, Sector Quebradón (Arenal Conservation Area), 500-600 m, $10^{\circ} 37^{\prime} \mathrm{N}, 84^{\circ} 54^{\prime} \mathrm{W}, 25$ Jan 2005 , Chaves 2047 (INB), López 6648 (INB), 6667 (INB). Volcán Poás National Park (Cordillera Volcánica Central Conservation Area), $2500-2600 \mathrm{~m}, 10^{\circ} 10^{\prime} \mathrm{N}, 84^{\circ} 13^{\prime} \mathrm{W}, 24 \mathrm{Apr}$ 2004, Chaves 1509 (INB). Volcán Tenorio National Park, Pilón Biological Station (Arenal-Tempisque Conservation Area), Tilarán Ridge, $84^{\circ} 59^{\prime} \mathrm{W}$, $10^{\circ} 43^{\prime} \mathrm{N}, 700 \mathrm{~m}$, lower montane cloud forest zone, exposed trees and fence posts along pasture, on bark (lower stem), 15 Mar 2004, Lücking 17208d (CR, F, USJ), 17221 (CR, F, USJ); on bark (lower trunk), 15 Mar 2004, Aptroot 60464 (ABL, INB), 60465 (ABL, INB), 60480 (ABL, INB), 60481 (ABL, INB), Lücking 17226 (CR, $\mathrm{F}$, USJ); on bark (lower trunk, living fence), 16 Mar
2004, Lücking $1725 \ln$ (F), 17251s (F); on wood, 15 Mar 2004, Aptroot 60400 (ABL, INB); partly disturbed primary forest, on bark (branch, fallen), 16 Mar 2004, Sipman 51908 (B, INB), 51915 (B, INB); on bark (lower trunk), 16 Mar 2004, Aptroot 60501 (ABL, INB); grazed, abandoned Syzygium jambos plantation surrounded by Gmelina arborea trees and pasture fields, 15 Mar 2004, Sipman 51775 (B, INB), 51787 (B, INB), 51804 (B, INB), 51861 (B, INB). Cartago: Ojo de Agua (Pacífico Central Conservation Area), 2900-3000 m, $9^{\circ} 37^{\prime} \mathrm{N}, 83^{\circ} 49^{\prime} \mathrm{W}, 21$ Mar 2000, Sipman 46589 (INB). Tapantí National Park (La Amistad Pacífico Conservation Area), trail to waterfall, $1400-1500 \mathrm{~m}, 9^{\circ} 44^{\prime} \mathrm{N}$, $83^{\circ} 47^{\prime} \mathrm{W}, 2$ Apr 2003, Chaves 507 (INB). Tapantí National Park, Tapantí Section, Tapantí Station (La Amistad Pacífico Conservation Area), Talamanca Ridge, $83^{\circ} 47^{\prime} \mathrm{W}, 9^{\circ} 44^{\prime} \mathrm{N}, 1700 \mathrm{~m}$, montane cloud forest zone, primary forest margin along roadside, on bark (branch, fallen), 2 Apr 2003, Buck 44044 (CR, NY); on bark (lower trunk), 2 Apr 2003, Lücking 16583 (F, INB); on trunk at road, 2 Apr 2003, Sipman 51074a (B, INB). Guanacaste: Finca del Estado, border of Guanacaste National Park, Pitilla Section (Guanacaste Conservation Area), 400-500 $\mathrm{m}, 11^{\circ} 01^{\prime} \mathrm{N}$, $85^{\circ} 24^{\prime} \mathrm{W}, 16$ Mar 2006, Chaves 2508 (INB), 2544 (INB). Miravalles Protection Zone, Finca Río Naranjo Section (Arenal Conservation Area), 1200-1250 m, $10^{\circ} 42^{\prime} \mathrm{N}, 85^{\circ} 07^{\prime} \mathrm{W}, 6$ Aug 2003, Chaves 873 (INB), 878 (INB), 884 (INB), 910 (INB), López 7174 (INB). Novasa Wind Power Project (Arenal-Tilarán Conservation Area), Tilarán Ridge, Tierras Morenas, $85^{\circ} 01^{\prime} \mathrm{W}$, $10^{\circ} 38^{\prime} \mathrm{N}, 750 \mathrm{~m}$, lower montane moist forest zone, exposed trees and fence posts along pasture, on bark (lower trunk), 23 Mar 2004, Lücking 17719 (CR, F, INB, USJ). Quebrada Azul, Tilarán (Arenal Conservation Area), $700-800 \mathrm{~m}, 10^{\circ} 31^{\prime} \mathrm{N}, 84^{\circ} 59^{\prime} \mathrm{W}, 1$ Mar 2003 , Chaves 2158 (INB). Volcán Tenorio (Arenal Conservation Area), trail to Río Celeste waterfall, 600-700 m, $10^{\circ} 33^{\prime} \mathrm{N}, 84^{\circ} 59^{\prime} \mathrm{W}$, secondary forest, 8 Oct 2002 , Chaves 83 (INB). Volcán Tenorio National Park, Alto Masis Section (Arenal-Tilarán Conservation Area), Tilarán Ridge, $85^{\circ} 00^{\prime} \mathrm{W}, 10^{\circ} 36^{\prime} \mathrm{N}, 850-900 \mathrm{~m}$, lower montane moist forest zone, exposed trees and fence posts and forest regrowth along savanna-like pasture, on bark (lower trunk), 17 Mar 2004, Lücking 17303a (CR, F, INB); on bark (twig), 17 Mar 2004, Lücking $17302 b$ (INB). Volcán Tenorio National Park, Rancho Capú Section (Arenal Conservation Area), 600-700 m, $10^{\circ} 34^{\prime} \mathrm{N}, 84^{\circ} 59^{\prime} \mathrm{W}, 19$ Apr 2006, Chaves 2591 (INB). Heredia: La Selva Protection Zone, La Selva Biological Station (Cordillera Volcánica Central Conservation Area), $50-100 \mathrm{~m}, 10^{\circ} 25^{\prime} \mathrm{N}, 84^{\circ} 00^{\prime} \mathrm{W}$, Jan 1997 , Lücking 97-15 (F). Limón: Braulio Carrillo National Park, Quebrada Gonzales Section (Cordillera Volcánica Central Conservation Area), Volcánica Central Ridge, $83^{\circ} 56^{\prime} \mathrm{W}, 10^{\circ} 10^{\prime} \mathrm{N}, 500 \mathrm{~m}$, lower montane rain forest zone, primary forest, on bark (trunk, fallen), 30 Mar 2003, Buck 44017 (CR, NY). Hitoy Cerere Biological Reserve, Hitoy Cerere Biological Station (La Amistad Caribe Conservation Area), Talamanca Ridge, $83^{\circ} 02^{\prime} \mathrm{W}, 9^{\circ} 40^{\prime} \mathrm{N}, 150 \mathrm{~m}$, lowland to lower montane rain forest zone, planted trees and secondary vegetation, on wood (log), 10 Mar 2004, Nelsen 3719 c (INB, WIS), 3719d (INB). Vicinity of U.S. Department of Agriculture Rubber Experimental Station, Los Diamantes, on Rio St. Clara, 7 Jul 1949, Holm \& Iltis 1496 
(FH). Puntarenas: Corcovado National Park, Sirena Section, Sirena Biological Station (Osa Conservation Area), Osa Peninsula, $83^{\circ} 35^{\prime} \mathrm{W}, 8^{\circ} 29^{\prime} \mathrm{N}$, sea level, lowland and coastal rain forest zone, old-growth coastal secondary forest and primary forest remnants on sandy soil, on bark (lower stem), 7 Apr 2003, Lücking 16222 (CR, F, USJ), Will-Wolf $12569 a$ (F, INB, WIS); coastal secondary forest and closed secondary vegetation on sandy soil, on bark (lower trunk), 7 Apr 2003, Lücking 16380a (CR, F, USJ). Floodplain of Rio Sandalo, peninsula of Osa, 1-10 m, 21-27 Aug 1930, Dodge \& Goerger 10187 (FH). La Amistad International Park, Altamira Station (La Amistad Pacífico Conservation Area), Talamanca Ridge, $83^{\circ} 00^{\prime} \mathrm{W}, 9^{\circ} 02^{\prime} \mathrm{N}$, 1600-1800 m, montane rain forest zone, secondary forest and open secondary vegetation dominated by Cecropia, on bark (branch), 1 Jul 2002, Lücking 15247 e (F); on bark (lower trunk), 1 Jul 2002, Lücking 15256d (F, INB); on bark (lower trunk), 1 Jul 2002, Sipman $48038 b$ (B, INB), $48046 a$ (B, INB). Las Cruces Biological Station and Wilson Botanical Garden near San Vito, 900-1000 m, montane rain forest zone, planted vegetation and disturbed forest, 10-24 Oct 2004, Lücking $18004 b$ (F, USJ), 18023 (F), 18035 (CR), 18036 (F), 18055 (F); 16 Oct 2004, Barillas S.n. (INB), Esquivel \& Cifuentes RE 3/MC 353 (INB), Paredes et al. 1071 (INB); young planted trees in meadow on hilltop, on thin trunk of Tabebuia chrysantha, 10-19 Oct 2004, Sipman 53342 (B, INB), 53378 a (B, INB). Monteverde Cloud Forest Reserve (Arenal Conservation Area), 1500-1600 m, $10^{\circ} 18^{\prime} \mathrm{N}, 84^{\circ} 47^{\prime} \mathrm{W}, 19$ Jan 2003, Chaves 195 (INB), 208 (INB), 258 (INB). San Vito, Las Cruces Biological Station and Wilson Botanical Garden (La Amistad Pacífico Conservation Area), $1200-1300 \mathrm{~m}, 8^{\circ} 47^{\prime} \mathrm{N}, 82^{\circ} 57^{\prime} \mathrm{W}$, 16 Oct 2004, Chaves 1991 (INB), Chaves 2033 (INB). San José: Forest along Rio Paquita, 1-3 m, 13 Sug 1936, Dodge \& Goerger 9745 (FH).

\section{Graphis rimulosa (Mont.) Trevis. Figure 12H.}

Graphis rimulosa (Mont.) Trevis., Spighe et Paglie: 11. 1853; Opegrapha rimulosa Mont., Ann. Sci. Nat. Bot., Ser. 2, 18: 271. 1842; Graphis rimulosa (Mont.) Müll. Arg., Bull. Soc. Roy. Bot. Belg. 30: 79. 1891 [nom. illeg., ICBN Art. 52.1]. Lectotype (fide Wirth \& Hale, 1978: 21). Guyana, Leprieur 200 (P).

Graphis rimulosa var. brachycarpa Müll. Arg. in Bailey, Bot. Bull. Dep. Agricult. Qld. 13: 27. 1896. Holotype. Australia (Queensland), Shirley 1821 (G!).

DiAGNOSIS-Thallus corticate, smooth to uneven, white-gray. Lirellae erumpent, rarely branched, lacking thalline margin, 1-3 mm long, $0.2-0.4 \mathrm{~mm}$ broad; labia striate. Excipulum completely carbonized. Hymenium clear. Ascospores 4-8 per ascus, transversely 7-11-septate, $30-50 \times 7-10 \mu \mathrm{m}$, hyaline. Secondary chemistry: no substances detected by TLC.

REMARKS-Distinguished from Graphis leptoclada by the completely carbonized excipulum, lack of thalline margin, and smaller ascospores. Most similar is G. dupaxana, which has promi- nent lirellae and smaller ascospores $(25-35 \mu \mathrm{m}$ long). Graphis striatula agrees in lirellae morphology but has slightly larger ascospores and a laterally carbonized excipulum. Graphis rimulosa var. brachycarpa (not to be confused with $G$. brachycarpa Müll. Arg. and G. brachycarpa Vain.!) was listed as a synonym of the latter by Archer (2006), but the type material has a completely carbonized excipulum and thus fits $G$. rimulosa. A syntype of $G$. assimilis $(\mathrm{H}-\mathrm{Nyl}$ 7122) also belongs to G. rimulosa.

Previously listed for Costa Rica by Müller Argoviensis (1891, 1893a); also reported by Breuss $(2000,2004)$. Also here belongs the material identified as G. albida Fink by Dodge, housed in $\mathrm{FH}$, while the specimen labeled by him as $G$. rimulosa actually is $G$. lumbricina.

Specimens SeEn_COSTA RICA. Alajuela: Huetar Norte, Boca Tapada, Refugio Nacional de Vida Silvestre Mixto Maquenque, $0-100 \mathrm{~m}, 10^{\circ} 42^{\prime} \mathrm{N}$, $84^{\circ} 11^{\prime} \mathrm{W}, 8$ May 2005, Chaves 2390 (INB); 5 Apr 2005, Chaves 2248 (INB). Sarchí village (Cordillera Volcánica Central Conservation Area), Central Valley, Sarchí, $84^{\circ} 22^{\prime} \mathrm{W}, 10^{\circ} 06^{\prime} \mathrm{N}, 1100 \mathrm{~m}$, lower montane rain forest zone, planted roadside trees and treelets along coffee plantation, on bark (lower trunk), 7 Jul 2002, Sipman 48369d (B, INB). Vicinity of Guatuso de San Rafael, 80-100 m, low tropical rain forest, with palms prominent in understory, Aug 1949, Holm \& Iltis $1510 B(\mathrm{FH})$. Volcán Tenorio National Park, Pilón Biological Station (Arenal-Tempisque Conservation Area), Tilarán Ridge, $84^{\circ} 59^{\prime} \mathrm{W}, 10^{\circ} 43^{\prime} \mathrm{N}, 700 \mathrm{~m}$, lower montane cloud forest zone, exposed trees and fence posts along pasture, on bark (lower stem), 15 Mar 2004, Lücking $17208 f(\mathrm{~F})$. Guanacaste: Along Rio Liberia NE of Liberia, 100 m, 13 Jan 1930, Dodge et al. 6362 (FH). Hacienda Santamaría, 680-780 m, 22 Jan 1930, Dodge \& Thomas 6777 (FH). Monte Alto Forest Reserve, Cerro Romo (Tempisque Conservation Area), Nicoya Peninsula, $85^{\circ} 24^{\prime} \mathrm{W}, 10^{\circ} 00^{\prime} \mathrm{N}, 750$ $900 \mathrm{~m}$, lowland to lower montane moist forest zone, exposed trees and fence posts along pasture, on bark (lower trunk), 22 Mar 2004, Lücking $17592 a$ (F, INB). Monte Alto, Mirador Section (Tempisque Conservation Area), $700-750 \mathrm{~m}, 10^{\circ} 00^{\prime} \mathrm{N}, 85^{\circ} 23^{\prime} \mathrm{W}, 6$ Jun 2003 , Chaves 581 (INB). Volcán Tenorio National Park, Alto Masis Section (Arenal-Tilarán Conservation Area), Tilarán Ridge, $85^{\circ} 00^{\prime} \mathrm{W}, 10^{\circ} 36^{\prime} \mathrm{N}, 850-900 \mathrm{~m}$, lower montane moist forest zone, exposed trees and fence posts and forest regrowth along savanna-like pasture, on bark (branch), 17 Mar 2004, Trest 1584c (INB). Limón: Hitoy Cerere Biological Reserve, Hitoy Cerere Biological Station (La Amistad Caribe Conservation Area), Talamanca Ridge, $83^{\circ} 02^{\prime} \mathrm{W}, 9^{\circ} 40^{\prime} \mathrm{N}, 100$ $150 \mathrm{~m}$, lowland to lower montane rain forest zone, exposed trees and fence posts along pasture, on bark (lower trunk), 10 Mar 2004, Trest 15l6d (INB); 150 m, lowland to lower montane rain forest zone, secondary vegetation and disturbed primary forest along river, on bark (lower stem), 9 Mar 2004, Lücking $17010 b$ (F, 
USJ). Puntarenas: La Amistad International Park, Altamira Station (La Amistad Pacífico Conservation Area), Talamanca Ridge, $83^{\circ} 00^{\prime} \mathrm{W}, 9^{\circ} 01^{\prime} \mathrm{N}, 1350$ $1450 \mathrm{~m}$, lower montane rain forest zone, exposed trees and fence posts along roadside pasture, on bark (lower stem, living fence), 29 Jun 2002, Lücking 15187a (F). Las Cruces Biological Station and Wilson Botanical Garden near San Vito, 900-1000 m, montane rain forest zone, planted vegetation and disturbed forest, 10-24 Oct 2004, Gonzales s.n. (INB).

\section{Graphis rockii Redinger. Figure 8F.}

Graphis rockii Redinger in Zahlbruckner, Hedwigia 76: 196. 1934. Holotype. China, s.col. (w, not seen).

DiAgnosis - Thallus corticate, smooth to uneven, white-gray. Lirellae prominent, rarely branched, lacking thalline margin, 1-3 mm long, $0.15-0.25 \mathrm{~mm}$ broad; labia striate. Excipulum apically carbonized. Hymenium clear. Ascospores 8 per ascus, transversely 5-13-septate, $25-45 \times 7-9 \mu \mathrm{m}$, hyaline. Secondary chemistry: no substances detected by TLC.

REMARKS-This species closely resembles Graphis duplicata and $G$. dupaxana in lirellae morphology and ascospores, and the three species form a series of increasing excipulum carbonization: apically in $G$. rockii, laterally in $G$. duplicata, and completely in $G$. dupaxana.

SPeCIMENS SeEN-COSTA RICA. Alajuela: Volcán Tenorio National Park, Pilón Biological Station (Arenal-Tempisque Conservation Area), Tilarán Ridge, $84^{\circ} 59^{\prime} \mathrm{W}, 10^{\circ} 43^{\prime} \mathrm{N}, 700 \mathrm{~m}$, lower montane cloud forest zone, exposed trees and fence posts along pasture, on bark (lower stem), 15 Mar 2004, Lücking $17214 c(\mathrm{~F})$.

\section{Graphis ruiziana (Fée) A. Massal. Figure 22F.}

Graphis ruiziana (Fée) A. Massal., Mem. Lichenogr.: 111. 1853; Opegrapha ruiziana Fée, Essai Crypt. Écorc.: 27. 1824; Graphina ruiziana (Fée) Müll. Arg., Mém. Soc. Phys. Genève 29(8): 38. 1887. Holotype. South America, unknown locality, Humboldt \& Bonpland S.n. (G!).

DiAgNosis-Thallus corticate, smooth to uneven, white-gray. Lirellae sessile, rarely branched, lacking thalline margin, jet-black, Melaspilea-like, $0.5-1.5 \mathrm{~mm}$ long, $0.2-0.4 \mathrm{~mm}$ broad; labia entire. Excipulum completely carbonized. Hymenium clear. Ascospores 4-8 per ascus, muriform, 35$65 \times 10-20 \mu \mathrm{m}$, hyaline. Secondary chemistry: no substances detected by TLC.

REMARKS - Graphis ruiziana is the most common and widespread member of the G. nuda group, even found in temperate Europe (Purvis et al., 1992). The species is characterized by its short, Melaspilea-like lirellae and medium-sized, muriform ascospores. The newly described $G$. subruiziana differs by its larger ascospores.

Also reported from Costa Rica by Müller Argoviensis (1891; as Graphina ruiziana) and Staiger (2002). The material identified as Graphina ruiziana (Fée) Müll. Arg. in FH is a mixture of Glyphis substriatula (Nyl.) Staiger, Graphis illinata, and G. granulosa.

Specimens SeEn_COSTA RICA. Alajuela: Volcán Tenorio National Park, Pilón Biological Station (Arenal-Tempisque Conservation Area), Tilarán Ridge, $84^{\circ} 59^{\prime} \mathrm{W}, 10^{\circ} 43^{\prime} \mathrm{N}, 700 \mathrm{~m}$, lower montane cloud forest zone, exposed trees and fence posts along pasture, on bark (lower trunk), 15 Mar 2004, Aptroot 60435 (ABL, INB). Cartago: Río Macho Forest Reserve, La Chonta, $5 \mathrm{~km} \mathrm{~S}$ of El Empalme on road to San Isidro del General, $83^{\circ} 56^{\prime} \mathrm{W}, 9^{\circ} 42^{\prime} \mathrm{N}, 2300 \mathrm{~m}$, fence posts and forest relics in pasture fields on mountain ridge, 11 Nov 1988, Sipman et al. 41752a (B, CR). Tapantí National Park, Macizo de la Muerte Section, Cerro de la Muerte (La Amistad Pacífico Conservation Area), Talamanca Ridge, Villa Mills, $83^{\circ} 43^{\prime} \mathrm{W}$, $9^{\circ} 33^{\prime} \mathrm{N}, 3100 \mathrm{~m}$, upper montane rain forest zone, disturbed oak forest, on bark (lower trunk), $12 \mathrm{Apr}$ 2003, Buck 44250 (INB, NY). Cartago: Genesis II Cloud Forest Reserve (La Amistad Pacífico Conservation Area), Talamanca Ridge, 2200-2500 m, montane rain forest to upper montane cloud forest zone, Feb 1997, Lücking 97-40 (F). San José: Cordillera de Talamanca, San Gerardo de Dota, study site LSF at Don Manuel, $3000 \mathrm{~m}$, rather old secundary forest with Quercus copeyensis, on trunk of Quercus copeyensis, shady, 22 Mar 1999, Holz CR99-0161 (B, INB). Los Santos Forest Reserve, Tres de Junio (Pacífico Central Conservation Area), Talamanca Ridge, $83^{\circ} 51^{\prime} \mathrm{W}, 9^{\circ} 39^{\prime} \mathrm{N}, 2750 \mathrm{~m}$, upper montane cloud forest zone, margin of disturbed oak forest, on wood (fence post), 25 Mar 2004, Lücking $17750 f(\mathrm{CR}, \mathrm{F}$, INB, USJ), $17750 \mathrm{ga}(\mathrm{F})$.

\section{Graphis rustica Kremp. Figure 16F.}

Graphis rustica Kremp., Nuovo Giorn. Bot. Ital. 7: 61 (1875). Lectotype (fide Nakanishi, annotation label in 1973). Singapore, Beccari 258 (M, not seen).

Graphis turgidula Müll. Arg., J. Linn. Soc. London Bot. 30: 457. 1895. Lectotype (fide Wirth \& Hale, 1978: 25). Mauritius. s.col. (BM).

Graphis marginifera Vain., Ann. Acad. Sci. Fenn., Ser. A, 15(6): 238. 1921. Holotype. Philippines, Merrill 7958 (TUR-Vainio 27867!).

Graphis tonglonensis Vain., Ann. Acad. Sci. Fenn., Ser. A, 15(6): 238. 1921. Holotype. Philippines, Merrill 7985 (TUR-Vainio 27863!).

Graphis kjellbergii Redinger, Ann. Mycol. 31: 170. 1933. Holotype. Indonesia (Celebes), Kjellberg $3 L$ (s 2178!).

DiAGNOSIS - Thallus corticate, smooth to uneven, yellowish gray. Lirellae prominent, partly branched, with thick lateral thalline margin, 1$6 \mathrm{~mm}$ long, $0.5-0.7 \mathrm{~mm}$ broad; labia entire, 
sharply delimited, jet-black. Excipulum completely carbonized. Hymenium clear. Ascospores 6-8 per ascus, transversely 9-17-septate, 60-100 $\times 10-14 \mu \mathrm{m}$, hyaline. Secondary chemistry: stictic acid.

REMARKS-Graphis rustica has the same lirellae morphology as $G$. oxyclada and $G$. flavens, with prominent lirellae featuring jetblack labia sharply delimited from a thick lateral thalline margin. The latter two species have smaller ascospores and lack secondary substances. Graphis marginata agrees in morphology and anatomy but has norstictic acid.

Archer (2006) established synonymy of Graphis turgidula with the earlier name G. rustica. Three further names are synonyms of this species, also indicated in part by Archer's annotation labels on the type material.

SPECIMENS SEen_COSTA RICA. Alajuela: Bijagua, Alto Los Brenes Section (Arenal Conservation Area), $700-800 \mathrm{~m}, 10^{\circ} 44^{\prime} \mathrm{N}, 85^{\circ} 02^{\prime} \mathrm{W}, 7$ Aug 2003, Chaves 972 (INB). Miravalles Protection Zone, Altamira Section (Arenal Conservation Area), 600-700 m, $10^{\circ} 44^{\prime} \mathrm{N}, 85^{\circ} 05^{\prime} \mathrm{W}, 8$ Aug 2003, Chaves 1044 (INB), $1055 a$ (INB); Finca Río Naranjo Section (Arenal Conservation Area), $1200-1250 \mathrm{~m}, 10^{\circ} 42^{\prime} \mathrm{N}, 85^{\circ} 07^{\prime} \mathrm{W}$, 6 Aug 2003, Chaves 854 (INB).

\section{Graphis sauroidea Leight. Figure 14C-D.}

Graphis sauroidea Leight., Trans. Linn. Soc. London 25: 452. 1866. Holotype. Brazil, Spruce 331 (BM, not seen).

Diagnosis-Thallus corticate, smooth to uneven, white-gray, UV- or UV+ yellow. Lirellae erumpent to prominent, partly branched, lacking or with basal thalline margin, $0.5-4 \mathrm{~mm}$ long, $0.3-0.4 \mathrm{~mm}$ broad; labia entire. Excipulum completely carbonized. Hymenium clear. Ascospores 8 per ascus, transversely $7-15$-septate, 45 $60 \times 10-14 \mu \mathrm{m}$, hyaline. Secondary chemistry: lichexanthone.

REMARKS-The species closely resembles Graphis flavens in morphology and ascospores and differs by its lirellae with basal thalline margin only and by the presence of lichexanthone. Staiger (2002) indicates a certain variation in the presence or absence of lichexanthone in this species, but the lichexanthonedeficient forms cited by her might represent a separate taxon.

Specimens SeEn_COSTA RICA. Alajuela: Huetar Norte, Boca Tapada, Refugio Nacional de Vida Silvestre Mixto Maquenque, $0-100 \mathrm{~m}, 10^{\circ} 42^{\prime} \mathrm{N}$, $84^{\circ} 11^{\prime} \mathrm{W}, 8$ Apr 2005, Chaves 2385 (INB-3942773).
Graphis schiffneri Zahlbr. Figure 10F.

Graphis schiffneri Zahlbr., Ann. Crypt. Exot. 1: 127. 1928. Holotype. Indonesia (Java), Schiffner s.n. (w, not seen).

DiAGNOSIS-Thallus corticate, smooth to uneven, yellowish gray. Lirellae erumpent, unbranched, with lateral thalline margin, 0.5$1 \mathrm{~mm}$ long, $0.1-0.2 \mathrm{~mm}$ broad; labia striate, white pruinose. Excipulum laterally (to thinly completely) carbonized. Hymenium clear. Ascospores 8 per ascus, transversely 5-9-septate, 24$32 \times 7-9 \mu \mathrm{m}$, hyaline. Secondary chemistry: norstictic acid.

REMARKS-The application of this name is somewhat unclear and preliminarily based on the circumscription given by Awasthi (1991). Graphis schiffneri resembles $G$. caesiella in most aspects, except that the lirellae are striate. However, the two forms do not seem to represent labiomorphs of the same species since the lirellae in $G$. caesiella are usually longer and more radiately branched. Also, the thallus is usually more yellow in the latter because of a high concentration of norstictic acid.

Specimens Seen_-COSTA RICA. Guanacaste: Lomas de Barbudal Biological Reserve, Lomas de Barbudal Station (Tempisque Conservation Area), Río Tempisque Bassin, $85^{\circ} 22^{\prime} \mathrm{W}, 10^{\circ} 30^{\prime} \mathrm{N}, 100 \mathrm{~m}$, lowland to lower montane moist forest zone, disturbed gallery forest and forest remnants, on bark (lower stem), 29 Mar 2003, Lücking 16108a (F), 16108c (F, CR); on bark (lower trunk), 29 Mar 2003, Lücking $16105 \mathrm{C}$ (F, INB). Monte Alto Forest Reserve, Monte Alto Biological Station (Tempisque Conservation Area), Nicoya Peninsula, $85^{\circ} 24^{\prime} \mathrm{W}, 10^{\circ} 02^{\prime} \mathrm{N}, 450$ $550 \mathrm{~m}$, lowland to lower montane moist forest zone, disturbed primary and old-growth secondary forest, on bark (lower trunk), 21 Mar 2004, Sipman 51969 (B, INB). Limón: Above unnamed tributary of Rio Siquirres, 70-170 m, 4 Dec 1929, Dodge et al. s.n. (FH). Along road Limón-Siquirres, near bridge on river Río Chirripó, $83^{\circ} 18^{\prime} \mathrm{W}, 10^{\circ} 03^{\prime} \mathrm{N}, 50 \mathrm{~m}$, on small trees among cultivated fields, 12 Nov 1988, Sipman et al. 41906 (B, CR).

\section{Graphis scripta (L.) Ach. Figure 9B.}

Graphis scripta (L.) Ach., Kgl. Vetensk.-Akad. Nya Handl.: 145. 1809; Lichen scriptus L., Spec. Plant. 2: 1140. 1753. Lectotype (fide Jørgensen et al., 1994: 381). Tab. XVIII and fig. 1 in Dillenius, Hist. Musc. Epitype. Sweden, Malme S.n. (UPS!; Malme, Lich. Suec. Exs. 47).

DiAGNOSIS-Thallus corticate, smooth to uneven, white-gray. Lirellae erumpent, partly branched, with lateral thalline margin, $1-5 \mathrm{~mm}$ long, $0.2-0.3 \mathrm{~mm}$ broad; labia entire; disc 
exposed. Excipulum laterally carbonized. Hymenium clear. Ascospores 8 per ascus, transversely 5-13-septate, 25-45(-55) × 6-9 $\mu \mathrm{m}$, hyaline. Secondary chemistry: no substances detected by TLC.

REMARKS-The concept of Graphis scripta in the literature is confusing, probably because of two reasons: (1) The species is usually not compared to the bulk of related tropical taxa, simply because it is assumed that $G$. scripta does not occur in the tropics. For example, Staiger (2002: 234) states that " $z u$ Graphis furcata werden hier alle Proben gestellt, die die gleichen Merkmale wie Graphis scripta aufweisen, jedoch aus den Tropen und nicht aus gemässigten Breiten stammen" ["to Graphis furcata we assign all material that has the same features as Graphis scripta but originates from the tropics and not from temperate latitudes"]. (2) It is generally assumed that there is only one species of "Eugraphis" present in temperate zones, this being G. scripta, and therefore the bulk of material collected has never been checked as to variation in anatomical details. For example, very few specimens have been routinely tested for ascospore size, so it seems that the enormous variation in length $(20-70 \mu \mathrm{m})$ cited in major treatments (Purvis et al., 1992; Wirth, 1995; Brodo et al., 2001; Staiger, 2002) is not based on proper observations of these authors but goes back to the statements of Poelt (1974); this is, for example, admitted by Staiger (2002: 255).

Based on our study of extensive material of Graphis from tropical regions (Mexico, Costa Rica, West Indies, Brazil, Papua New Guinea) and more than 600 type specimens, we could elaborate a rather solid species concept, including many features, such as lirellae morphology, excipulum carbonization, hymenium inspersion, ascospore septation and size, and chemistry. We have so far not found a single species for which an ascospore length variation as described for $G$. scripta could be admitted. In cases of morphologically similar taxa with different ascospore sizes, analytical evaluation shows discontinuities that usually permit one to separate the several species. These analyses also show that there are certain "preferred" ascospore sizes, such as the small ascospores $(20-40 \mu \mathrm{m})$ typical of most species in "Eugraphis," that is, the G. scripta group. It thus seemed odd to us that G. scripta should exhibit such an enormous variation, and we therefore checked about 50 specimens from North America and Europe to verify this. As a result, we found that most mature ascospores are $25-45 \mu \mathrm{m}$ in length, thus fitting well into the typical "Eugraphis" ascospore size. Ascospores below $25 \mu \mathrm{m}$ are usually immature, and only very rarely (less than $5 \%$ ) did we find ascospores up to $55 \mu \mathrm{m}$ but never exceeding that value. However, a recent study from Great Britain contradicts our findings and seems to confirm that Graphis scripta indeed has ascospores ranging from 20 to $70 \mu \mathrm{m}$ in length (Pentecost, 2003).

Within the framework of a species concept that also considers tropical material, G. scripta can therefore be characterized by immersederumpent lirellae with basal to lateral thalline margin; exposed, white pruinose or, more rarely, nonpruinose, dark brown disc; laterally carbonized excipulum; clear hymenium; small (to medium-sized?), transversely septate ascospores; and lacking lichen substances. Most of the tropical taxa of "Eugraphis" can indeed be separated from G. scripta but because of morphological, anatomical or chemical features and not merely because of their distribution (Table 6). Yet G. scripta s.str. does occur in the tropics, as demonstrated here by the collections from Costa Rica, which agree in all features with the bulk of collections from North America and Europe. The species most similar to $G$. scripta are not $G$. furcata or any of the other species listed by Staiger (2002: 235) but the following (Table 6): G. pyrrhocheiloides (norstictic acid), G. crebra (inspersed, norstictic acid), G. apertella (inspersed, norstictic acid), G. chondroplaca (inspersed, norstictic acid; for discussion of the latter three see also comments under G. chondroplaca), and G. submarginata Lücking (inspersed); all these are externally indistinguishable from G. scripta. Graphis furcata itself is well distinguished by its very thin, usually wavy lirellae with the disc always concealed.

One feature that has to be studied further in tropical Graphis species is the taxonomic importance of apothecial pruina. So far, we are using this character in separating species (see, e.g., comments under $G$. chondroplaca) because in many cases it correlates with other characters. It is assumed that this character is variable in G. scripta, and since we are not suggesting that one recognize pruinose and nonpruinose populations of that species as different species, the cases where apothecial pruina is used as only character to separate tropical species should probably be revised. 
TABLE 6. Comparison of names described in the Graphis scripta group (erumpent lirellae, lateral thalline margin, laterally carbonized excipulum, and small transversely septate ascospores). Taxa are arranged first by lirellae morphology (disc exposed versus concealed), then by hymenium inspersion, and then by chemistry to facilitate comparison of names of closely related species. Interestingly, no synonyms are obvious, except for the epithets crebra and apertella, which apparently refer to the same taxon.

\begin{tabular}{llll}
\hline Species & \multicolumn{1}{c}{ Disc } & Hymenium & Chemistry \\
\hline inversa R. C. Harris & exposed, pruinose & clear & anthraquinones \\
pyrrhocheiloides Zahlbr. & exposed, pruinose & clear & norstictic \\
ferruginea Vain. & exposed, pruinose & clear & salazinic \\
scripta (L.) Ach. & exposed, pruinose & clear & nil \\
chondroplaca (Redinger) Lücking & exposed & inspersed & norstictic \\
crebra Vain. & exposed, pruinose & inspersed & norstictic \\
apertella Archer & exposed, pruinose & inspersed & norstictic \\
subnarginata Lücking & exposed, pruinose & inspersed & nil \\
librata C. Knight. & concealed & clear & norstictic \\
stipitata A. W. Archer & concealed & clear & norstictic, lichexanthone \\
subasalinae Nagarkar \& Patw. & concealed & clear & norstictic, stictic, salazinic \\
litoralis Lücking et al. & concealed & clear & norstictic, protocetraric, salazinic \\
immersella Müll. Arg. & concealed & clear & stictic \\
supracola A. W. Archer & concealed & clear & protocetraric \\
palmyrensis Zahlbr. & concealed & clear & nil \\
furcata Fée & concealed, labia wavy & clear & nil \\
tenellula Vain. & concealed & inspersed & norstictic \\
leptocarpa Fée & concealed & inspersed & stictic \\
lineola Ach. & concealed & inspersed & nil \\
caesiella Vain. & concealed, labia pruinose & clear & norstictic \\
dendrogramnla Nyl. & concealed, labia pruinose & clear & stictic \\
bakeri Vain. & concealed, labia pruinose & clear & salazinic \\
plumierae Vain. & concealed, labia pruinose & inspersed & norstictic, salazinic \\
\hline
\end{tabular}

Specimens Seen-COSTA RICA. Alajuela: Volcán Tenorio National Park, Pilón Biological Station (Arenal-Tempisque Conservation Area), Tilarán Ridge, $84^{\circ} 59^{\prime} \mathrm{W}, 10^{\circ} 43^{\prime} \mathrm{N}, 700 \mathrm{~m}$, lower montane cloud forest zone, exposed trees and fence posts along pasture, on bark (lower trunk), 15 Mar 2004, Sipman 51793 (B, INB). Limón: Gandoca-Manzanillo Wildlife Refuge, Manzanillo Section (La Amistad Caribe Conservation Area), Manzanillo, $82^{\circ} 53^{\prime} \mathrm{W}, 9^{\circ} 38^{\prime} \mathrm{N}$, sea level, lowland coastal moist forest zone, disturbed coastal vegetation with Cocos nucifera, Coccoloba uvifera, on bark (lower stem), 11 Mar 2004, Sipman 51736 (B, INB). Puntarenas: Isla del Caño Biological Reserve (Osa Conservation Area), $0-100 \mathrm{~m}, 8^{\circ} 42^{\prime} \mathrm{N}, 83^{\circ} 52^{\prime} \mathrm{W}, 27$ Aug 2003, Navarro 7126 (INB), 7127 (INB). Potrero Grande savannas (La Amistad Pacífico Conservation Area), Terraba Valley, Clavera, $83^{\circ} 11^{\prime} \mathrm{W}, 8^{\circ} 59^{\prime} \mathrm{N}, 250 \mathrm{~m}$, lowland moist forest savanna zone, disturbed roadside savanna and pasture, on bark (lower trunk), 3 Jul 2002, Sipman 48160 (B, INB).

\section{Graphis seminuda Müll. Arg. Figure 13C.}

Graphis seminuda Müll. Arg., Bull. Soc. Roy. Bot. Belg. 30: 79. 1891. Lectotype (here selected!). Costa Rica, Pittier 5241 (G!, Us, isolectotype!). Syntype. Costa Rica, Pittier 5139 (G!), s.n. (G!).

Graphis seminuda var. sublaevis Müll. Arg., Bull. Soc. Roy. Bot. Belg. 30: 79. 1891. Lectotype (here selected). Costa Rica, Pittier s.n. (G!).

Graphis catherinae A. W. Archer, Austral. Syst. Bot. 14: 259. 2001. Holotype. Australia (Queensland),
Streimann 28307 (CANB, photograph seen; H!, Us!, isotypes).

DiAGNOSIS-Thallus ecorticate, farinose, bluish white-gray. Lirellae prominent, partly branched, with lateral thalline margin, $1-6 \mathrm{~mm}$ long, $0.4-0.6 \mathrm{~mm}$ broad; labia entire, white pruinose. Excipulum completely carbonized. Hymenium clear. Ascospores 4-8 per ascus, transversely 11-13-septate, $40-65 \times 8-11 \mu \mathrm{m}$, hyaline. Secondary chemistry: no substances detected by TLC.

REMARKS-Based on its description and comments made by Wirth and Hale $(1963,1978)$, this taxon was first thought to possibly represent a synonym of Graphis rhizocola or an excipulomorph of the latter, according to Wirth and Hale (1963, 1978) characterized by a basally uncarbonized excipulum. We have studied the syntypes in $G$ and found the excipulum to be completely carbonized. The species is indeed similar to G. rhizocola, but the ecorticate, farinose thallus, pruinose labia, and the shorter ascospores suggest a closer relationship to the group formed by $G$. sitiana, $G$. furcata, $G$. pavoniana, and G. farinulenta.

The three syntypes of Graphis seminuda all represent exactly the same stage of this species, 
and Pittier 5241 was selected as lectotype since it is best developed and has a duplicate in US. The five syntypes of $G$. seminuda var. sublaevis belong to four different species: the collections made by Tonduz (s.n., one from Boruca, the other from Terraba) represent $G$. rlizocola, and the two collections with the same number, Pittier 5244, are $G$. virescens and $G$. flavens, respectively. The specimen Pittier s.n. is the same as G. seminuda and here selected as lectotype. Graphis catherinae also agrees well with $G$. seminuda (A. W. Archer, pers. comm., 2007).

Dodge used both the name Graphis seminuda and $G$. seminuda var. sublaevis to identify part of his Costa Rican material at $\mathrm{FH}$, but, unfortunately, the specimens turned out to be $G$. acharii, $G$. rimulosa, and $G$. furcata.

SPeCimens SeEn-COSTA RICA. Cartago: Barbilla National Park (La Amistad Caribe Conservation Area), main trail to Río Danta, $9^{\circ} 59^{\prime} \mathrm{N}, 83^{\circ} 29^{\prime} \mathrm{W}$, 400-500 m, 16 Feb 2003, Chaves 384 (INB). Barra Honda National Park, Cerro Barra Honda, $10 \mathrm{~km}$ ENE of Nicoya, along main trail to Terciopelo cave and Mirador, $85^{\circ} 22^{\prime} \mathrm{W}, 10^{\circ} 10^{\prime} \mathrm{N}, 450 \mathrm{~m}$, on trunk in dry, deciduous forest on limestone, 22 Mar 2004, Sipman 52040 (B, INB). Lomas Barbudal Biological Reserve (Tempisque Conservation Area), 100-200 m, $10^{\circ} 27^{\prime} \mathrm{N}$, $85^{\circ} 21^{\prime} \mathrm{W}$, 5 Oct 2002, Chaves $78 b$ (INB); Lomas de Barbudal Station (Tempisque Conservation Area), Río Tempisque Bassin, $85^{\circ} 22^{\prime} \mathrm{W}, 10^{\circ} 30^{\prime} \mathrm{N}$ $100 \mathrm{~m}$, lowland to lower montane moist forest zone, disturbed gallery forest and forest remnants, on bark (lower stem), 29 Mar 2003, Lücking $16118 g$ (F, INB), Sipman 51045 c (B, USJ). Palo Verde Station (Tempisque Conservation Area), Río Tempisque Bassin, $85^{\circ} 21^{\prime} \mathrm{W}, 10^{\circ} 21^{\prime} \mathrm{N}, 10-50 \mathrm{~m}$, lowland to lower montane moist forest zone, disturbed primary forest remnants and open secondary forest, on bark (lower trunk), 28 Mar 2003, Sipman $50997 b$ (B, INB), 51001 (B, CR); on bark (lower trunk), 28 Mar 2003, Sipman 50995 (B, INB). Puntarenas: Carara National Park, Quebrada Bonita Section (Pacífico Central Conservation Area), $84^{\circ} 35^{\prime} \mathrm{W}, 9^{\circ} 47^{\prime} \mathrm{N}, 100 \mathrm{~m}$, lowland moist forest zone, partly disturbed dense primary forest with understory dominated by Erythrochiton gymnanthus, on bark (lower trunk), 18 Jul 2002, Sipman 48382e (B, INB).

\section{Graphis sitiana Vain. Figure 12A.}

Graphis sitiana Vain., Acta Soc. Fauna F1. Fenn. 7(2): 120. 1890. Holotype. Brazil, Vainio 533 (TUR-Vainio 27854!).

DiAGNOSIS-Thallus ecorticate, farinose, bluish white-gray. Lirellae prominent, partly branched, with (apically thin) complete thalline cover, $1-5 \mathrm{~mm}$ long, $0.1-0.2 \mathrm{~mm}$ broad; labia entire, white pruinose. Excipulum completely carbonized. Hymenium clear. Ascospores 8 per ascus, transversely 3-5-septate, $20-30 \times 7-9 \mu \mathrm{m}$, hyaline. Secondary chemistry: no substances detected by TLC.

REMARKS - The specimens cited below fit the type from Brazil perfectly. Graphis sitiana closely resembles $G$. farinulenta and $G$. seminuda both morphologically and anatomically but has very small, 5-septate ascospores. A further specimen (Chaves 2352, INB) was found with larger, 7septate ascospores; it might also belong here or represent an undescribed taxon.

Specimens Seen-COSTA RICA. Puntarenas: Las Cruces Biological Station and Wilson Botanical Garden near San Vito, 900-1000 m, montane rain forest zone, planted vegetation and disturbed forest, 10-24 Oct 2004, Lücking 18021 (F); $82^{\circ} 58^{\prime} \mathrm{W}, 8^{\circ} 47^{\prime} \mathrm{N}$, $1200 \mathrm{~m}$, young planted trees in meadow on hilltop, on thin trunk of Terminalia catappa, 10-19 Oct 2004, Sipman 53328b (B); on thin trunk of Tabebuia chrysantha, Sipman 53378 (B, INB-3993884).

\section{Graphis stenotera Vain. Figure $8 \mathrm{H}$.}

Graphis stenotera Vain., Ann. Acad. Sci. Fenn., Ser. A, 15(6): 243. 1921. Lectotype (fide Archer 2006: 86). Philippines, Felix12786 (TUR-Vainio 27887!). Graphis flabellans Zahlbr., Feddes Repert. 31: 211. 1933. Holotype. Taiwan [Formosa], Asahina s.n. (w!).

DiAGNOSIS-Thallus corticate, smooth to uneven, white-gray. Lirellae erumpent, rarely branched, lacking thalline margin, 1-3 $\mathrm{mm}$ long, $0.15-0.3 \mathrm{~mm}$ broad; labia striate. Excipulum apically carbonized. Hymenium clear. Ascospores 8 per ascus, transversely 5-9-septate, $25-40 \times$ 6-9 $\mu \mathrm{m}$, hyaline. Secondary chemistry: stictic acid.

REMARKS - This species closely resembles Graplis rockii in morphology and ascospores, but differs in the presence of stictic acid. It is one of the few species in this group producing lichen substances. Synonymy of Graphis flabellans with G. stenotera is based on Hale's index cards.

Specimens Seen_COSTA RICA. Puntarenas: Las Cruces Biological Station and Wilson Botanical Garden near San Vito, 900-1000 m, montane rain forest zone, planted vegetation and disturbed forest, 10-24 Oct 2004, Lïcking 18015 (F).

\section{Graphis striatula (Ach.) Spreng. Figure 9H.}

Graphis striatnla (Ach.) Spreng., Syst. Veg. Lich. 4: 250. 1827; Opegrapha striatula Ach., Syn. Meth. Lich.: 74. 1814. Holotype. Guinea, s.col. (H-Ach 629 !).

Graphis striatula var. substellaris Redinger, Ark. Bot. 27(3): 49. 1935. Lectotype (here selected!). Brazil, Malme 2251 (s 6487!). Syntype. Brazil, Malme 3635 (s 6488!). 
DiagNoSIS-Thallus corticate, smooth to uneven, white-gray. Lirellae prominent, partly to radiately branched, lacking thalline margin, 0.5 $3 \mathrm{~mm}$ long, $0.2-0.3 \mathrm{~mm}$ broad; labia striate. Excipulum laterally (to thinly completely) carbonized. Hymenium clear. Ascospores 48 per ascus, transversely 9-15-septate, 40-60 × 8$12 \mu \mathrm{m}$, hyaline. Secondary chemistry: no substances detected by TLC.

REMARKS - A typical representative of the Graphis duplicata group, characterized by its laterally carbonized excipulum and mediumsized ascospores. Graphis haleana is indistinguishable except for the presence of lichexanthone. Previously reported from Costa Rica by Müller Argoviensis (1893a). Graphis striatula var. substellaris has more strongly branched lirellae, but this difference is not sufficient to merit taxonomic rank.

Specimens Seen-COSTA RICA. Puntarenas: La Amistad International Park, Cerro Biolley Section, Sabanas Esperanza (La Amistad Pacífico Conservation Area), Terraba Valley, $83^{\circ} 03^{\prime} \mathrm{W}, 9^{\circ} 04^{\prime} \mathrm{N}, 1300-$ $1400 \mathrm{~m}$, lowland to lower montane moist forest savanna zone, disturbed savanna vegetation with abundant shrubs and trees, on bark (lower trunk), 2 Jul 2002, Sipman 48108a (B, INB). Las Cruces Biological Station and Wilson Botanical Garden near San Vito, 900-1000 m, montane rain forest zone, planted vegetation and disturbed forest, 10-24 Oct 2004, Lücking 18018 (F), 18041 (F), Sipman 53317 (B, INB); 16 Oct 2004, De Gracia S.n. (INB). Mellizas, Finca Santa Marta, foot of Cerro Quijada del Diablo (La Amistad Pacífico Conservation Area), 1600-1700 m, $8^{\circ} 53^{\prime} \mathrm{N}, 82^{\circ} 45^{\prime} \mathrm{W}, 30$ Aug 2002, Navarro $5289 c$ (INB). Potrero Grande savannas (La Amistad Pacífico Conservation Area), Terraba Valley, Clavera, $83^{\circ} 11^{\prime} \mathrm{W}, 8^{\circ} 59^{\prime} \mathrm{N}, 250 \mathrm{~m}$, lowland moist forest savanna zone, disturbed roadside savanna and pasture, on bark (lower trunk), 3 Jul 2002, Lücking 15321i (F).

Graphis subchrysocarpa Lücking, nom. nov. Figure $7 \mathrm{C}$

Phaeographis ochracea C. W. Dodge, Ann. Missouri Bot. Gard. 40: 320.1953 [non Graphis ochracea Hepp]. Type. Sierra Leone, Deighton M-4307 (FH!).

DiAgNOSIS-Thallus corticate, smooth to uneven, white-gray. Lirellae prominent, rarely branched, lacking thalline margin, 1-5 mm long, 0.25-0.4 mm broad; labia (entire to) striate, orange pruinose, $\mathrm{K}+$ pink-purple. Excipulum completely carbonized. Hymenium colorless, clear. Ascospores 6-8 per ascus, terminally muriform, $70-120 \times 10-15 \mu \mathrm{m}$, hyaline. Secondary chemistry: anthraquinones.
REMARKS-This species is morphologically identical with Graphis chrysocarpa and differs only in the smaller, terminally muriform ascospores; it thus represents a "sporomorph" of the latter. For a more detailed discussion on this complex of species, see under G. chrysocarpa and G. miniata. At first we intended to describe this species as new, until we came across the type material of Phaeographis ochracea, which, in spite of its original generic assignment, has hyaline, I+ violet ascospores and agrees completely with the neotropical material. Unfortunately, however, the epithet ochracea cannot be used in Graphis since the name Graphis ochracea Hepp already exists (the latter belongs in Diorygma).

Specimens SeEn-COSTA RICA. Puntarenas: Carara National Park, Quebrada Bonita Section (Pacífico Central Conservation Area), $84^{\circ} 35^{\prime} \mathrm{W}, 9^{\circ} 47^{\prime} \mathrm{N}, 100 \mathrm{~m}$, lowland moist forest zone, partly disturbed dense primary forest with understory dominated by Erythrochiton gymnanthus, on bark (lower stem), 18 Jul 2002, Sipman 48383i (B).

\section{Graphis subcontorta (Müll. Arg.) Lücking \& Chaves, comb. nov. Figure 19H.}

Graphina subcontorta Müll. Arg., Rev. Mycol. 10: 120. 1888. Type. Paraguay, Balansa 183 (G!).

Diagnosis-Thallus corticate, smooth to uneven, gray. Lirellae erumpent, rarely branched, with (apically thin) complete thalline cover, 1$5 \mathrm{~mm}$ long, $0.3-0.5 \mathrm{~mm}$ broad; labia entire. Excipulum apically (to peripherally) carbonized. Hymenium clear. Ascospores single, muriform, $80-100 \times 30-40 \mu \mathrm{m}$, hyaline. Secondary chemistry: no substances detected by TLC.

REMARKS - Graphis subcontorta is a typical representative of the $G$. insulana group, having immersed-erumpent lirellae with thin complete thalline margin and single, large muriform ascospores. It seems to be most closely related to G. streblocarpa, which differs in having stictic acid. Graphis insulana can be separated by its inspersed hymenium and presence of norstictic acid. The provisional name G. pseudoserpentina was used in our Internet key (www.fieldmuseum. org/ticolichen/keys_graphis.html) before we became aware that there is a name available for this taxon.

Specimens SeEn-COSTA RICA. Guanacaste: Santa Elena Reserve (Arenal Conservation Area), $900-1000 \mathrm{~m}, 10^{\circ} 21^{\prime} \mathrm{N}, 84^{\circ} 46^{\prime} \mathrm{W}$, cloud forest, $14 \mathrm{Jan}$ 2003, Chaves 108c (INB-3762428). Volcán Tenorio National Park, Alto Masis Section (Arenal-Tilarán 
Conservation Area), Tilarán Ridge, $85^{\circ} 00^{\prime} \mathrm{W}$ $10^{\circ} 36^{\prime} \mathrm{N}, 850-900 \mathrm{~m}$, lower montane elfin cloud forest zone, on tree in disturbed forest near Tierras Morenas, 17 Mar 2004, Aptroot 60649 (ABL, INB-3968063).

Graphis subflexibilis Lücking \& Chaves, sp. nov. Figure $17 \mathrm{C}-\mathrm{F}$.

Sicut Graphis vestitoides sed hymenio insperso et lirellis latioribus differt. Holotype. COSTA RICA. Guanacaste: Tilarán, Parcelas, Quebrada Azul, (Arenal-Tempisque Conservation Area), $84^{\circ} 58^{\prime} \mathrm{W}, 10^{\circ} 30^{\prime} \mathrm{N}, 700 \mathrm{~m}$, borders of way and areas of pasturing, on bark (lower trunk), 1 Mar 2003, Chaves 423 (INB-3773636).

Paratypes. COSTA RICA. Puntarenas: La Amistad International Park, Altamira Station (La Amistad Pacífico Conservation Area), Talamanca Ridge, $83^{\circ} 00^{\prime} \mathrm{W}, 9^{\circ} 02^{\prime} \mathrm{N}, 1600-1800 \mathrm{~m}$, montane rain forest zone, secondary forest and open secondary vegetation dominated by Cecropia, on bark (branch), 1 Jul 2002, Lücking 15274g (F), Sipman 48043b (B, INB-3944703); Cerro Biolley Section, Sabanas Esperanza (La Amistad Pacífico Conservation Area), Terraba Valley, $83^{\circ} 03^{\prime} \mathrm{W}$, $9^{\circ} 04^{\prime} \mathrm{N}, 1300-1400 \mathrm{~m}$, lowland to lower montane moist forest savanna zone, disturbed savanna vegetation with abundant shrubs and trees, on bark (branch), 2 Jul 2002, Lücking 15301c (F). Las Cruces Biological Station and Wilson Botanical Garden near San Vito, 900-1000 m, montane rain forest zone, planted vegetation and disturbed forest, 10-24 Oct 2004, Lücking 18022 (CR), 18029 a (F); 16 Oct 2004, Colín 17 (INB), Sipman 53320 (B, INB-3993725). Las Tablas Protection Zone, El Progreso Station (La Amistad Pacífico Conservation Area), Talamanca Ridge, $82^{\circ} 48^{\prime} \mathrm{W}$, $8^{\circ} 54^{\prime} \mathrm{N}, 1300 \mathrm{~m}$, lower montane rain forest zone, shade trees and fence posts along roadside coffee plantations, on bark (lower stem, living fence), 28 Jun 2002, Lücking 150601 (F).

DESCRIPTION-Thallus corticolous, $1-3 \mathrm{~cm}$ diam., $50-100 \mu \mathrm{m}$ thick, continuous; surface smooth to uneven, pale gray to white; prothallus absent. Thallus in section with cartilaginous upper cortex, irregular algal layer and clusters of crystals. Apothecia lirelliform, straight to flexuose, partly branched, prominent, with thin complete thalline margin, 1-6 mm long, 0.4$0.6 \mathrm{~mm}$ wide, $0.3-0.4 \mathrm{~mm}$ high; disc concealed; proper margin very thick, labia striate, grayish black to gray; thalline margin laterally thick, pale gray to white (in first-generation lirellae with irregular inner edges), apically thin (cortex), gray. Excipulum entire (in first generation of lirellae) to usually striate, completely carbonized, $80-150 \mu \mathrm{m}$ wide, black; laterally covered by corticate algiferous thallus including clusters of crystals; hypothecium prosoplectenchymatous, $10-15 \mu \mathrm{m}$ high, colorless to pale yellowish; hymenium 150-250 $\mu \mathrm{m}$ high, colorless, inspersed (type B); epithecium indistinct. Paraphyses unbranched; asci fusiform, 100-200 × 20-30 $\mu \mathrm{m}$. Ascospores 6-8 per ascus, oblong to narrowly fusiform, terminally muriform with 15-29 transverse and 1-2 longitudinal septa in terminal segments, $80-140 \times 10-20 \mu \mathrm{m}, 6-8$ times as long as wide, colorless to slightly grayish brown. Secondary chemistry: no substances detected by TLC.

REMARKS-Graphis subflexibilis is another new species in the $G$. cinerea aggregate, including taxa with (entire to) striate labia, completely carbonized excipulum, and inspersed hymenium. The rather broad lirellae of $G$. subflexibilis are reminescent of $G$. angustata, but that species has transversely septate ascospores and a clear hymenium. Within the $G$. cinerea aggregate, $G$. bettinae and $G$. argentata seem to be most closely related, the first having entire labia and transversely septate ascospores, the second having regularly muriform ascospores. Graphis vestitoides appears to be the noninspersed counterpart of G. subflexibilis, although its lirellae are usually narrower.

ECOLOGY-Like the other species of this aggregate, Graphis subflexibilis seems to be restricted to partly exposed microsites in montane rain forests with high amount of precipitation.

Graphis subhiascens (Müll. Arg.) Lücking, comb. nov. Figure $21 \mathrm{~F}$.

Graphina subhiascens Müll. Arg., Bot. Jahrb. 20: 2811. 1894. Holotype. Tanzania, Holst 696 (G!).

DiAgNOSIS-Thallus corticate, smooth to uneven, gray. Lirellae erumpent, rarely branched, with thick complete thalline cover, $1-5 \mathrm{~mm}$ long, $0.3-0.5 \mathrm{~mm}$ broad; labia entire. Excipulum laterally carbonized. Hymenium clear. Ascospores single, muriform, 80-110 × 20-30 $\mu \mathrm{m}$, hyaline. Secondary chemistry: no substances detected by TLC.

REMARKS-This species is very similar to Graphis insulana but differs in its clear hymenium and absence of lichen substances. Graphina $x y$ lophaga R. C. Harris (Harris, 1990) is closely related to G. subhiascens; it differs by its lateral thalline margin with exposed, black labia, and 1 2-spored asci.

Specimens SeEn-COSTA RICA. Guanacaste: Santa Elena Reserve (Arenal Conservation Area), 900-1000 m, $10^{\circ} 21^{\prime} \mathrm{N}, 84^{\circ} 46^{\prime} \mathrm{W}$, cloud forest, 14 Jan 2003, Chaves 112k (INB-4015995). Volcán Tenorio National Park, Alto Masis Section (Arenal-Tilarán Conservation Area), Tilarán Ridge, $85^{\circ} 00^{\prime} \mathrm{W}$, 
$10^{\circ} 37^{\prime} \mathrm{N}, 950-1000 \mathrm{~m}$, lower montane elfin cloud forest zone, disturbed low elfin forest and secondary vegetation, on bark (lower stem), 17 Mar 2004, Aptroot 60619 (ABL, INB).

Graphis submarginata Lücking, nom. nov. Figure $11 \mathrm{C}$.

Graphis marginata G. Mey. \& Flot., Lich. Nova Acta Acad. Leopold.-Carol. 19, Suppl.: 229. 1843 [nom. illeg., ICBN Art. 53.1; non G. marginata Raddi]; Graphis lineola var. marginata (G. Mey. \& Flot.) Zahlbr., Cat. Lich. Univ. 2: 317. 1924. Holotype. Indonesia (Java), s.col. (not seen).

DiAGNOSIS-Thallus corticate, smooth to uneven, white-gray. Lirellae erumpent, rarely branched, with lateral thalline margin, 1-3 mm long, $0.1-0.2 \mathrm{~mm}$ broad; labia entire; disc exposed, white pruinose. Excipulum laterally carbonized. Hymenium inspersed (type A). Ascospores 8 per ascus, transversely 5-9-septate, 25-35 × 6-8 $\mu \mathrm{m}$, hyaline. Secondary chemistry: no substances detected by TLC.

REMARKS-This taxon belongs in the Graphis scripta aggregate, characterized by laterally carbonized excipulum, exposed discs, and small, transversely septate ascospores. Among this aggregate, $G$. submarginata is the only species that has an inspersed hymenium and lacks lichen substances (see Table 4 and comments under $G$. chondroplaca and $G$. scripta). It is thus very similar to $G$. scripta itself, except for the inspersed hymenium. We have not seen the type of Graphis marginata, and our taxonomic assessment is based on a rich collection identified with that name by Redinger from Paraguay (s).

The name Graphis marginata Raddi already existed when Meyen and Flotow (1843) established their new species G. marginata G. Mey. \& Flot., and a new name is necessary for this taxon.

SpeCimens SeEn-COSTA RICA. Guanacaste: Lomas de Barbudal Biological Reserve, Lomas de Barbudal Station (Tempisque Conservation Area), Río Tempisque Bassin, $85^{\circ} 22^{\prime} \mathrm{W}, 10^{\circ} 30^{\prime} \mathrm{N}, 100 \mathrm{~m}$, lowland to lower montane moist forest zone, disturbed gallery forest and forest remnants, on bark (lower stem), 29 Mar 2003, Lü̈king 16111 g (F, INB-4011873). San José: University Campus $2 \mathrm{~km}$ E of San José, N of San Pedro church, $84^{\circ} 03^{\prime} \mathrm{W}, 9^{\circ} 56^{\prime} \mathrm{N}, 1200 \mathrm{~m}$, on tree in secundary forest remnant, 8 Mar 2005, Aptroot 60027 (ABL, USJ).

Graphis subruiziana Sipman, Chaves \& Lücking, sp. nov. Figure $22 \mathrm{G}$.

Sicut Graphis ruiziana sed ascosporis maioribus differt. Holotype. COSTA RICA. San José: Los Santos Forest Reserve, Tres de Junio (Pacífico Central Conservation Area), Talamanca Ridge, $83^{\circ} 51^{\prime} \mathrm{W}, 9^{\circ} 39^{\prime} \mathrm{N}, 2750 \mathrm{~m}$, upper montane cloud forest zone, margin of disturbed oak forest, on wood (fence post), 25 Mar 2004, Lücking 17750gb (F, holotype).

Paratypes. COSTA RICA. Cartago. Río Macho Forest Reserve, La Chonta, $5 \mathrm{~km} \mathrm{~S}$ of $\mathrm{El}$ Empalme on road to San Isidro del General, $83^{\circ} 56^{\prime} \mathrm{W}, 9^{\circ} 42^{\prime} \mathrm{N}, 2300 \mathrm{~m}$, fence posts and forest relics in pasture fields on mountain ridge, $11 \mathrm{Nov}$ 1988, Sipman et al. 41752 (B, CR). San José. Río Macho Forest Reserve, W of Cerro Asunción, $83^{\circ} 45^{\prime} \mathrm{W}, 9^{\circ} 34^{\prime} \mathrm{N}, 3200 \mathrm{~m}$, disturbed mossy forest with boggy clearings, 21 Mar 2000, Sipman \& Umaña 46586 (B, INB).

DESCRIPTION-Thallus corticolous, $2-7 \mathrm{~cm}$ diam., $50-150 \mu \mathrm{m}$ thick, continuous; surface uneven, pale gray to white; prothallus absent. Thallus in section with cartilaginous upper cortex, irregular algal layer and clusters of crystals. Apothecia lirelliform, straight, rarely branched, sessile, lacking thalline margin, 0.5$1.5 \mathrm{~mm}$ long, $0.3-0.5 \mathrm{~mm}$ wide, $0.35-0.5 \mathrm{~mm}$ high; disc concealed; proper margin very thick, labia entire, black. Excipulum entire, completely carbonized, 100-150 $\mu \mathrm{m}$ wide, black; hypothecium prosoplectenchymatous, $20-30 \mu \mathrm{m}$ high, yellowish; hymenium 180-250 $\mu \mathrm{m}$ high, colorless, clear; epithecium indistinct. Paraphyses unbranched; asci clavate, 150-200 $\mu \mathrm{m}$ long, 40$50 \mu \mathrm{m}$ wide. Ascospores $2-4$ per ascus, ellipsoid, muriform, 55-90 × 20-35 $\mu \mathrm{m}, 2-3$ times as long as wide, colorless. Secondary chemistry: no substances detected by TLC.

REMARKS-This new species is a typical representative of the Graphis nuda group, having sessile, very short, black lirellae resembling a Melaspilea species. Within that group, G. subruiziana is closest to $G$. ruiziana but has distinctly larger ascospores (those of $G$. ruiziana not exceeding $65 \mu \mathrm{m}$ ). Also, the lirellae of G. ruiziana usually have a thin white pruina along the slit, while those of $G$. subruiziana are mostly nonpruinose.

ECOLOGY-Like the other species of this aggregate, Graphis subruiziana prefers open situations in upper montane rain and cloud forests.

\section{Graphis subturgidula Lücking \& Sipman, sp. nov.} Figure 17G.

Sicut Graphis rustica sed ascosporis in cellulis terminalibus septis longitudinalibus instructis ("biocellatis") differt. Holotype. COSTA RICA. Puntarenas: Carara National Park, Quebrada Bonita Section (Pacífico Central Conservation Area), $84^{\circ} 35^{\prime} \mathrm{W}, 9^{\circ} 47^{\prime} \mathrm{N}, 100 \mathrm{~m}$, lowland moist forest zone, partly disturbed dense primary forest 
with understory dominated by Erythrochiton gymnanthus, on bark (lower stem), 18 Jul 2002, Sipman 48390a (INB-3987215, holotype; B, isotype).

DESCRIPTION-Thallus corticolous, crustose, 3-7 cm diam., 50-120 $\mu \mathrm{m}$ thick, continuous; surface smooth to uneven, pale gray to white; prothallus absent. Thallus in section with cartilaginous upper cortex, irregular algal layer and clusters of crystals. Apothecia lirelliform, flexuose, partly branched, prominent, with thin complete thalline margin, 1-5 mm long, 0.3$0.5 \mathrm{~mm}$ wide, $0.2-0.3 \mathrm{~mm}$ high; disc concealed; proper margin very thick, labia entire, dark gray with white pruinose-hyphose cover; thalline margin laterally thick, pale gray to white, apically thin (cortex), gray. Excipulum entire, completely carbonized, 50-100 $\mu \mathrm{m}$ wide, black; laterally covered by corticate algiferous thallus including clusters of crystals; hypothecium prosoplectenchymatous, $10-20 \mu \mathrm{m}$ high, colorless to pale yellowish; hymenium $140-170 \mu \mathrm{m}$ high, colorless; epithecium indistinct. Paraphyses unbranched; asci fusiform, 130-150 $\mu \mathrm{m}$ long, 20$30 \mu \mathrm{m}$ wide. Ascospores 6-8 per ascus, oblong, terminally muriform with 15-21 transverse and $0-1$ longitudinal septa in terminal segments, 75 $95 \times 11-14 \mu \mathrm{m}, 6-7$ times as long as wide, colorless. Secondary chemistry: stictic acid.

REMARKS - Graphis subturgidula belongs in the G. rhizocola group and is characterized by terminally muriform ascospores and presence of stictic acid. So far, no species with muriform ascospores and stictic acid has been known in this group, and only one other species, G. firferi, has terminally muriform ascospores, the latter differing from $G$. subturgidula by its yellow pruinose lirellae. Within the species with transversely septate ascospores in this group, only $G$. rustica has prominent lirellae and stictic acid but can be distinguished by its thick lateral thalline margin, which is absent from the jet-black, upper part of the labia.

ECOLOGY - Collected in the shaded understory of a rather dry, evergreen lowland rain forest.

\section{Graphis subvirginea Nyl. Figure 13B.}

Graphis subvirginea Nyl. in Leight., Trans. Linn. Soc. London 25: 452. 1866. Lectotype (fide Awasthi \& Mathur, annotation in 1989). Brazil, Spruce 341 (H-Nyl 7138!).

DiAGNOSIS-Thallus corticate, smooth to uneven, white-gray. Lirellae erumpent, rarely branched, with thick complete thalline cover,
1-3 mm long, 0.1-0.2 mm broad; labia entire. Excipulum (laterally to) completely carbonized. Hymenium clear. Ascospores 8 per ascus, transversely 7-9-septate, $20-35 \times 5-7 \mu \mathrm{m}$, hyaline. Secondary chemistry: no substances detected by TLC.

REMARKS-Graphis subvirginea resembles several other species in the G. scripta group with entire labia, completely carbonized excipulum and small, transversely septate ascospores. The species are distinguished chiefly by lirellae morphology, ranging from sessile and lacking thalline margin ( $G$. geraensis) to prominent with pruinose labia ( $G$. sitiana) to erumpent with lateral thalline margin ( $G$. dracenae) to immersed with thick complete thalline margin (G. subvirginea). Graphis subvirginea somewhat resembles a species of Diorygma, hence the epithet subvirginea: Graphina virginea is now included in Diorygma as D. poitaei (Kalb et al., 2004).

Specimens Seen_COSTA RICA. Puntarenas: Las Cruces Biological Station and Wilson Botanical Garden near San Vito, 900-1000 m, montane rain forest zone, planted vegetation and disturbed forest, 16 Oct 2004, Mercado 13 (INB, PR), 19 (INB).

\section{Graphis supertecta Müll. Arg. Figure 8B.}

Graphis supertecta Müll. Arg., Bull. Soc. Roy. Bot. Belg. 30: 77. 1891. Lectotype (fide Awasthi \& Mathur, annotation label in 1989). Costa Rica, Tonduz s.n. (G!).

DiAGNOSIS--Thallus corticate, smooth to uneven, yellowish to bluish white-gray. Lirellae immersed, partly branched, with lateral thalline margin, $1-5 \mathrm{~mm}$ long, $0.1-0.2 \mathrm{~mm}$ broad; labia striate, white pruinose. Excipulum apically (to peripherally) carbonized. Hymenium clear. Ascospores 6-8 per ascus, transversely 11-15septate, 40-70 $\times 8-12 \mu \mathrm{m}$, hyaline. Secondary chemistry: no substances detected by TLC.

REMARKS-This is one of the few species originally described from Costa Rica. The original material is quite heterogeneous: while morphologically similar, it includes two collections with at least three different taxa with either apically or completely carbonized excipula and with or without stictic acid. The specimen with apically carbonized excipulum and lacking lichen substances (A) is similar to Graphis glaucescens but differs in its corticate thallus; there seems to be no other name available for this taxon. The specimens with completely carbonized excipulum ( $\mathrm{B}$ in the same collection) can be accommodated in $G$. rimulosa if the ascospores agree with those 
described for $G$. supertecta, but we did not find ascospores in these specimens. The second collection contains a taxon with apically carbonized excipulum and stictic acid, which agrees perfectly with G. vittata Müll. Arg. and seems to be the first report for this taxon in the Neotropics. In order to preserve the name Graphis supertecta and not having to describe a new species, we therefore follow Awasthi and Mathur (annotation label on type) in selecting the specimen with apically carbonized excipulum and lacking lichen substances as lectotype. A syntype of G. glaucovirens Redinger (s 6504!) also belongs to this species.

Specimens SeEN-COSTA RICA. The lectotype. Alajuela: Colinas de San Pedro de San Ramón, 16 Jan 1934, Brenes 18979 (FH).

\section{Graphis symplecta Nyl. Figure 18E-F.}

Graphis simplecta Nvl., Ann. Sci. Nat., Bot., Sér 4. 20: 263. 1863. Holotype. Colombia, Lindig s.n. (H-Nyl 7404!).

DIAGNOSIS - Thallus corticate, smooth to uneven, white-gray. Lirellae immersed, partly branched, with (apically thin) complete thalline cover, 1-3 mm long, 0.1-0.15 mm broad; labia striate. Excipulum apically (to peripherally) carbonized. Hymenium clear. Ascospores 6-8 per ascus, muriform, $3645 \times 15-20 \mu \mathrm{m}$, hyaline. Secondary chemistry: no substances detected by TLC.

REMARKS-Graphis symplecta is very closely related to $G$. disserpens, and the latter is here maintained on account of the erumpent lirellae not covered by thallus and the smaller number of ascospores per ascus.

SPeCIMENS SEeN-COSTA RICA. Alajuela: Volcán Tenorio National Park, Pilón Biological Station (Arenal-Tempisque Conservation Area), Tilarán Ridge, $84^{\prime} 59^{\prime} \mathrm{W}, 10^{\prime} 43^{\prime} \mathrm{N}, 700-900 \mathrm{~m}$, lower montane cloud forest zone, partly disturbed primary forest, on bark (branch, fallen), 16 Mar 2004, Sipman 51910 (B, INB). Guanacaste: Palo Verde National Park, Palo Verde Station (Tempisque Conservation Area), Río Tempisque Bassin, $85^{\prime} 23^{\prime} \mathrm{W}, 10^{\prime} 22^{\prime} \mathrm{N}, 10 \mathrm{~m}$, lowland to lower montane moist forest zone, disturbed open primary and secondary forest, on bark (lower stem), 28 Mar 2003, Sipman 51004 (B, INB). Puntarenas: Las Tablas Protection Zone, La Neblina Section (La Amistad Pacífico Conservation Area), Talamanca Ridge, $82^{\circ} 45^{\prime} \mathrm{W}, 8^{\circ} 55^{\prime} \mathrm{N}, 1600 \mathrm{~m}$, montane rain forest zone, pasture with scattered trees and stumps, on bark (lower trunk), 27 Jun 2002, Sipman 47901 a (B, INB).

Graphis tenella Ach. Figure 9C.

Graphis tenella Ach., Syn. Meth. Lich.: 81. 1814. Type. Guinea, s.col. (H-Ach 585!).
Phaeographis sulcata Müll. Arg., Flora 69: 313. 1886. Holotype. Jamaica, Hart 101 (G!).

Graphis subglauconigra Nagarkar \& Patw., Biovigyanam 8: 130. 1982. Holotype. India (not seen).

DiAgNosis-Thallus corticate, smooth to uneven, white-gray. Lirellae erumpent, rarely branched, with lateral thalline margin, $1-3 \mathrm{~mm}$ long, $0.15-0.25 \mathrm{~mm}$ broad; labia (entire to) striate. Excipulum laterally carbonized. Hymenium clear. Ascospores 8 per ascus, transversely 5-9-septate, $20-30 \times 6-8 \mu \mathrm{m}$, hyaline. Secondary chemistry: no substances detected by TLC.

REMARKS - Wirth and Hale (1978) and Staiger (2002) already recognized that this species differs from the morphologically very similar taxa in the Graphis scripta group in having striate lirellae. However, in all collections seen by us, including the type, only the older lirellae have stria, while the younger lirellae in the thallus periphery are always entire and then look similar to species in the G. scripta group. We have not seen type material of Graphis subglauconigra, but based on the description (Nagarkar \& Patwardhan, 1982) and the key by Awasthi (1991), there can be little doubt that this represents a synonym of $G$. tenella. The latter was previously reported from Costa Rica by Müller Argoviensis (1891) and was also found among the material in $\mathrm{FH}$, misidentified as $G$. intricata Fée.

Specimens SeEn-COSTA RICA. Alajuela: Colinas de San Pedro de San Ramón, 16 Jan 1934, Brenes 18955 (FH), 18956 (FH). Guanacaste: Hacienda Santamaría, 680-780 m, 24 Jan 1930, Dodge \& Thomas s.n. (FH). Monte Alto Forest Reserve, Monte Alto Biological Station (Tempisque Conservation Area), Nicoya Peninsula, $85^{\circ} 24^{\prime} \mathrm{W}, 10^{\circ} 02^{\prime} \mathrm{N}, 450-550 \mathrm{~m}$, lowland to lower montane moist forest zone, planted, shaded trees near station facilities, on bark (lower stem), 22 Mar 2004, Lücking 17650e (CR, F, INB, USJ). Palo Verde National Park, Palo Verde Station (Tempisque Conservation Area), Río Tempisque Bassin, $85^{\circ} 21^{\prime} \mathrm{W}, 10^{\circ} 21^{\prime} \mathrm{N}, 10-50 \mathrm{~m}$, lowland to lower montane moist forest zone, disturbed primary forest remnants and open secondary forest, on bark (lower stem), 27 Mar 2003, Sipman 51005 b (INB, B); on bark (lower trunk), 28 Mar 2003, Sipman 50993 (INB). Puntarenas: Las Cruces Biological Station and Wilson Botanical Garden near San Vito, 900-1000 m, montane rain forest zone, planted vegetation and disturbed forest, Feb 2000, Lücking 00-11 (F); 10-24 Oct 2004, Lücking 18003 (F), 18013 (F), 18017 (USJ), $18029 b$ (INB), 18039 (F), Lücking 18049 (CR); 16 Oct 2004, Bárcenas Peña 101 (INB), Mercado 4 (INB, PR), Trest 1914 (INB). San José: Vicinity of Santa Maria de Dota, 1500-1800 m, 26 Dec 1925-3 Jan 1926, Standley \& Valerio 44128 (FH). 
Graphis tenellula Vain. Figure 11F.

Graphis tenellula Vain., Ann. Acad. Sci. Fenn., Ser. A, 6: 160. 1915. Lectotype (fide Nakanishi, annot. 1973). Dominican Republic, Raunkiaer 490 (TURVainio 27701!).

Graphis tenella var. jatrophae Vain., Ann. Acad. Sci. Fenn., Ser. A, 15(6): 248. 1921. Holotype. Philippines, Merrill 6344 (TUR-Vainio 27722!).

Graphis spodoplaca Zahlbr., Ann. Mycol. 30: 429. 1932. Holotype. China, Chung $596 f$ (w!).

Graphis inspersa Redinger, Ark. Bot. 27A(3): 50. 1935. Holotype. Paraguay, Malme $1663 f$ (S 6500!)

Graphis tenellula var. eutypodes Vain. [nom. inval., ICBN Art. 32, 35-37]. Original material. Philippines, Merrill 6736 (TUR-Vainio 27706!).

DiAgNosis-Thallus corticate, smooth to uneven, white-gray. Lirellae erumpent, unbranched, with basal to lateral thalline margin, 1-3 mm long, $0.1-0.2 \mathrm{~mm}$ broad; labia entire. Excipulum laterally carbonized. Hymenium inspersed (type A). Ascospores 8 per ascus, transversely 7-9-septate, 35-45 × 6-8 $\mu \mathrm{m}$, hyaline. Secondary chemistry: norstictic acid.

REMARKS - Graphis tenellula is very similar and closely related to both $G$. leptocarpa and $G$. lineola. All three have the same apothecial morphology and anatomy, inspersed hymenium, and small transversely septate ascospores and differ only in their chemistry: $G$. tenellula has norstictic acid, while G. leptocarpa has stictic acid, and $G$. lineola lacks lichen substances. This group of species illustrates the problems of the concept of regarding chemically empty chemomorphs as representing loss mutations since if one would apply that concept here, there would be no way to tell whether a specimen lacking chemistry (fitting $G$. lineola) would be a loss mutation of either the norstictic acid ( $G$. tenellula) or the stictic acid chemomorph ( $G$. leptocarpa).

The material identified as Graphis tenellula in FH represents $G$. librata.

Specimens Seen-COSTA RICA. Alajuela: Arenal National Park, Peninsula section (Arenal Conservation Area), $500-600 \mathrm{~m}, 10^{\circ} 27^{\prime} \mathrm{N}, 84^{\circ} 45^{\prime} \mathrm{W}, 11$ Jan 2004, Chaves 1159 (INB). Heredia: Instituto Nacional de Biodiversidad (INBio) campus (Cordillera Volcánica Central Conservation Area), Central Valley, Santo Domingo, $84^{\circ} 05^{\prime} \mathrm{W}, 9^{\circ} 59^{\prime} \mathrm{N}, 1150 \mathrm{~m}$, lower montane moist forest zone, planted trees and secondary forest on institute campus, on bark (lower stem), 14 Mar 2004, Sipman 51756 (B, INB). San José: Universidad de Costa Rica Campus (Cordillera Volcánica Central Conservation Area), Central Valley, San José, $84^{\circ} 03^{\prime} \mathrm{W}, 9^{\circ} 56^{\prime} \mathrm{N}, 1200 \mathrm{~m}$, lower montane moist forest zone, planted trees on campus, on bark (lower trunk), Feb 1997, Lücking 97-70 (F).
Graphis tenoriensis Chaves \& Lücking, sp. nov. Figure 19E-G.

Sicut Graphis myrtacea sed excipulo parte laterali et basali pallido differt. Holotype. COSTA RICA. Alajuela: Volcán Tenorio National Park, Pilón Biological Station (Arenal-Tempisque Conservation Area), Tilarán Ridge, $84^{\circ} 59^{\prime} \mathrm{W}, 10^{\circ} 43^{\prime} \mathrm{N}, 700$ $900 \mathrm{~m}$, lower montane cloud forest zone, partly disturbed primary forest, on bark (branch), $16 \mathrm{Mar}$ 2004, Lücking 17265 aa (USJ, holotype; F, isotype).

Paratypes. Volcán Tenorio National Park, Pilón Biological Station (Arenal-Tempisque Conservation Area), Tilarán Ridge, $84^{\circ} 59^{\prime} \mathrm{W}, 10^{\circ} 43^{\prime} \mathrm{N}$, $700 \mathrm{~m}$, lower montane cloud forest zone, exposed trees and fence posts along pasture, on bark (log, rotten, wet), 16 Mar 2004, Lücking 17252x (F), on bark (lower trunk, living fence), 16 Mar 2004 , Lïcking $17251 \mathrm{~m}$ (F). Palo Verde National Park. Palo Verde Station (Tempisque Conservation Area), Río Tempisque Bassin, 85⒉' W. $10^{\circ} 22^{\prime} \mathrm{N}, 10 \mathrm{~m}$, lowland to lower montane moist forest zone, disturbed open primary and secondary forest, on bark (lower trunk), 28 Mar 2003. Lücking 16534 (F, INB). Volcán Tenorio National Park, Alto Masis Section (Arenal-Tilarán Conservation Area), Tilarán Ridge, $85^{\circ} 00^{\prime} \mathrm{W}$, $10^{\circ} 37^{\prime} \mathrm{N}, 950-1000 \mathrm{~m}$. lower montane elfin cloud forest zone, disturbed low elfin forest and secondary vegetation, on bark (branch), 17 Mar 2004, Lücking 17341 (CR, F). San José: Along road from San Jerónimo to Alto La Palma, $N$ of San José, $84^{\circ} 01^{\prime} \mathrm{W}, 10^{\circ} 00^{\prime} \mathrm{N}, 1500 \mathrm{~m}$, on fence poles and scattered trees among pasture fields and gardens, 8 Nov 1988. Sipnan et al. 41551 (B, CR).

DESCRIPTION-Thallus corticolous, $3-5 \mathrm{~cm}$ diam., $50-100 \mu \mathrm{m}$ thick, continuous; surface uneven, white to pale greenish gray; prothallus absent. Thallus in section with thick cartilaginous upper cortex, irregular algal layer and clusters of crystals. Apothecia lirelliform, flexuose, partly branched, erumpent, with lateral thalline margin, 3-7 $\mathrm{mm}$ long, $0.3-0.5 \mathrm{~mm}$ wide, $0.2-0.3 \mathrm{~mm}$ high; disc concealed; proper margin thick, labia striate, jet-black with conspicuous white lines along striae; thalline margin laterally thick, white. Excipulum crenulate, apically carbonized, 50-100 $\mu \mathrm{m}$ wide, black, lateral and basal parts yellowish brown; space between carbonized upper parts of excipulum filled with clusters of calcium oxalate crystals; laterally covered by corticate algiferous thallus including clusters of crystals; hypothecium prosoplectenchymatous, $10-20 \mu \mathrm{m}$ high, colorless to pale yellowish; hymenium 150-200 $\mu \mathrm{m}$ high, colorless, clear; epithecium granulose. 5-15 $\mu \mathrm{m}$ high. olive brown. Paraphyses unbranched: asci fusiform, $140-180 \times 30-40 \mu \mathrm{m}$. Ascospores $1-2$ per ascus, ellipsoid, muriform, $70-100 \times 20-30 \mu m$. 
3-4 times as long as wide, colorless. Secondary chemistry: no substances detected by TLC.

REMARKS-Graphis tenoriensis is a very conspicuous species because of its rather large lirellae with jet-black labia that eventually develop striae filled with crystals and visible as conspicuous white lines. It closely resembles $G$. myrtacea, which was found at the same locality, but the latter differs by its (laterally to) completely carbonized excipulum. There is also some similarity with $G$. gomezii, another new species described from the same locality, but that taxon has entire labia, a completely carbonized excipulum, and much smaller ascospores.

The lirellae in all available specimens of Graphis tenoriensis start out having entire, jetblack labia and only eventually become striate. In one specimen, most of the lirellae are entire. We therefore suspected that a name described for a taxon with entire lirellae but otherwise identical features could exist for this material. However, the only species that have entire lirellae with apically carbonized excipulum, clear hymenium, and large muriform ascospores are G. subcontorta, G. britannica Staiger, and G. triphora Nyl.; all differ clearly in other morphological features from $G$. tenoriensis.

ECOLOGY - Apparently a lower montane species preferring habitats with high amount of precipitation.

\section{Graphis tumidula (Fée) Spreng. Figure 15H.}

Graphis tumidula (Fée) Spreng., Syst. Veg. 4(1): 250. 1827; Opegrapha tumidula Fée, Essai Crypt. Ecorc.: 32. 1824. Holotype. Peru, s.col., (G, not seen).

DiAGNOSIS-Thallus corticate, smooth to uneven, green-gray. Lirellae prominent, rarely branched, with complete thalline cover lacking crystals, $1-3 \mathrm{~mm}$ long, $0.3-0.5 \mathrm{~mm}$ broad; labia entire. Excipulum completely carbonized. Hymenium clear. Ascospores 48 per ascus, transversely 19-39-septate, $120-300 \times 15-22 \mu \mathrm{m}$, hyaline. Secondary chemistry: no substances detected by TLC.

REMARKS-Graphis tumidula is a very characteristic species, not only because of the very large ascospores but also because of the often metallic thallus and thick thalline cover of the prominent labia.

Specimens SeEn_COSTA RICA. Cartago: Tapantí National Park, Tapantí Section, Tapantí Station (La Amistad Pacífico Conservation Area), Talamanca Ridge, $83^{\circ} 48^{\prime} \mathrm{W}, 9^{\circ} 46^{\prime} \mathrm{N}, 1150 \mathrm{~m}$, montane rain forest zone, living fence trees along roadside pasture, on bark (lower stem), 2 Apr 2003, Lücking 16598 (F, INB).

Graphis vestitoides (Fink) Staiger. Figure 17B.

Graphis vestitoides (Fink) Staiger, Bibl. Lichenol. 85: 263. 2002; Graphina vestitoides Fink, Mycologia 19: 218. 1927. Lectotype (fide Wirth \& Hale, 1978: 44). Puerto Rico, Fink 1986 (MICH, not seen).

Phaeographis cerviculata Redinger, Ark. Bot. 27A(3): 76. 1935. Holotype. Brazil, Malme 3531 (s!).

DiAGNOSIS-Thallus corticate, smooth to uneven, white-gray. Lirellae prominent, partly branched, with thin complete thalline margin, 1-8 $\mathrm{mm}$ long, $0.5-0.8 \mathrm{~mm}$ broad; labia striate. Excipulum completely carbonized. Hymenium clear. Ascospores 2-6 per ascus, terminally muriform, 80-140 × 12-16 $\mu \mathrm{m}$, hyaline. Secondary chemistry: no substances detected by TLC.

REMARKS - This species is most similar to Graphis acharii and differs only in its terminally muriform ascospores. Graphis aquilonia has the same ascospore type but produces norstictic acid, and its lirellae resemble those of $G$. marginata and $G$. rustica in the thick lateral thalline margin. Previously reported from Costa Rica by Müller Argoviensis (1893a) as Graphis acharii var. vestitoides and by Breuss (2000, 2001).

SpeCimens SEen_COSTA RICA. Alajuela: Huetar Norte, Boca Tapada, Refugio Nacional de Vida Silvestre Mixto Maquenque, 0-100 m, $10^{\circ} 42^{\prime} \mathrm{N}$, $84^{\circ} 11^{\prime} \mathrm{W}, 8$ May 2005, Chaves 2308 (INB). Volcán Tenorio National Park, Pilón Biological Station (Arenal-Tempisque Conservation Area), Tilarán Ridge, $84^{\circ} 59^{\prime} \mathrm{W}, 10^{\circ} 43^{\prime} \mathrm{N}, 700 \mathrm{~m}$, lower montane cloud forest zone, exposed trees and fence posts along pasture, on bark (lower trunk), 15 Mar 2004, Lücking $17212 \mathrm{~b}$ (F); 16 Mar 2004, Aptroot 60568 (ABL, INB), 60575 (ABL, INB). Cartago: Barbilla National Park (La Amistad Caribe Conservation Area), main trail to Río Danta. 400-500 m, 9 $59^{\prime} \mathrm{N}, 83^{\circ} 29^{\prime} \mathrm{W}, 16$ Feb 2003, Chaves 366 (INB), 380 (INB). Guanacaste: Quebrada Azul village (Arenal-Tilarán Conservation Area), Tilarán Ridge, Quebrada Azul, $84^{\circ} 58^{\prime} \mathrm{W}, 10^{\circ} 31^{\prime} \mathrm{N}$, $650 \mathrm{~m}$, lowland to lower montane moist forest zone, secondary vegetation along road, on bark (lower trunk), 17 Mar 2004, Lücking 17420a (F, INB), $17420 b$ (F). Quebrada Azul, Tilarán (Arenal Conservation Area), $700-800 \mathrm{~m}, 10^{\circ} 31^{\prime} \mathrm{N}, 84^{\circ} 59^{\prime} \mathrm{W}, 1 \mathrm{Mar}$ 2003, Chaves 424 (INB). Volcán Tenorio National Park, Alto Masis Section (Arenal-Tilarán Conservation Area), Tilarán Ridge, $85^{\circ} 00^{\prime} \mathrm{W}, 10^{\circ} 36^{\prime} \mathrm{N}, 850$ $900 \mathrm{~m}$, lower montane moist forest zone, exposed trees and fence posts and forest regrowth along savanna-like pasture, on bark (lower trunk), 17 Mar 2004, Lücking $17307 \mathrm{~m}(\mathrm{~F}) ; 85^{\circ} 00^{\prime} \mathrm{W}, 10^{\circ} 37^{\prime} \mathrm{N}, 950-1000 \mathrm{~m}$, lower montane elfin cloud forest zone, disturbed low elfin forest and secondary vegetation, on bark (twig), 17 Mar 2004, Lücking 17340b (F). Limón: GandocaManzanillo Wildlife Refuge, Manzanillo Section (La Amistad Caribe Conservation Area), Manzanillo, 
$82^{\circ} 53^{\prime} \mathrm{W}, 9^{\circ} 38^{\prime} \mathrm{N}$, sea level, lowland coastal moist forest zone, disturbed coastal vegetation with Cocos nucifera, Coccoloba uvifera, on bark (lower trunk), 11 Mar 2004, Lücking 17088d (F, USJ). Hitoy Cerere Biological Reserve, Hitoy Cerere Biological Station (La Amistad Caribe Conservation Area), Talamanca Ridge, $83^{\circ} 02^{\prime} \mathrm{W}, 9^{\circ} 40^{\prime} \mathrm{N}, 100-150 \mathrm{~m}$, lowland to lower montane rain forest zone, exposed trees and fence posts along pasture, on wood (fence post), 10 Mar 2004, Sipman 51658 (B, INB); 150-300 m, lowland to lower montane rain forest zone, partly disturbed primary forest, on bark (lower trunk), 10 Mar 2004, Lücking $17026 f$ (F). Puntarenas: Las Cruces Biological Station and Wilson Botanical Garden near San Vito, 900-1000 m, montane rain forest zone, planted vegetation and disturbed forest, 10-24 Oct 2004, Lücking 18001 (F), 18032 (F). Potrero Grande savannas (La Amistad Pacífico Conservation Area), Terraba Valley, Clavera, $83^{\circ} 11^{\prime} \mathrm{W}, 8^{\circ} 59^{\prime} \mathrm{N}, 250 \mathrm{~m}$, lowland moist forest savanna zone, disturbed roadside savanna and pasture, on bark (lower trunk), 3 Jul 2002, Sipman 48161 (B, INB).

\section{Graphis virescens Müll. Arg. Figure 12E.}

Graphis virescens Müll. Arg., Flora 63: 20. 1880. Holotype. Brazil, Puiggari 337 (G!).

Graphis conferta Zenk. in Goebel \& Kunze, Pharmazeut. Waarenkunde 1: 166 (1829). Type. Unknown locality, s.col. (not seen).

DiAGNOSIS-Thallus corticate, smooth to uneven, white-gray. Lirellae sessile, rarely branched, lacking thalline margin, jet-black, Melaspilea-like, $0.5-2 \mathrm{~mm}$ long, $0.2-0.3 \mathrm{~mm}$ broad; labia entire. Excipulum completely carbonized. Hymenium clear. Ascospores 8 per ascus, transversely 7-11-septate, 25-45 $\times 7$ $10 \mu \mathrm{m}$, hyaline. Secondary chemistry: no substances detected by TLC.

REMARKS-This is the member of the Graphis nuda group with the smallest ascospores. Most similar is G. geraensis, which has more elongate, prominente lirellae with basal thalline margin. Graphis emersa differs only in the presence of norstictic acid. The synonymy of Graphis conferta with $G$. virescens is suggested on the basis of the description by Müller Argoviensis (1887), although he indicates broader ascospores for $G$. conferta.

SPECIMENS SEen - COSTA RICA. Guanacaste: Arenal-Monteverde Protection Zone, San Gerardo Biological Station (Arenal Conservation Area), 1100 $1200 \mathrm{~m}, 10^{\circ} 22^{\prime} \mathrm{N}, 84^{\circ} 48^{\prime} \mathrm{W}, 16$ Jan 2003 , Chaves 141 (INB). Monte Alto, Mirador Section (Tempisque Conservation Area), $700-750 \mathrm{~m}, 10^{\circ} 00^{\prime} \mathrm{N}, 85^{\circ} 23^{\prime} \mathrm{W}$, 6 Jun 2003, Chaves 629 (INB). Puntarenas: Las Cruces Biological Station and Wilson Botanical Garden near San Vito, 900-1000 m, montane rain forest zone, planted vegetation and disturbed forest, 10-24 Oct 2004, Lücking 18026 (CR).
Graphis vittata Müll. Arg. Figure $8 \mathrm{G}$.

Graphis vittata Müll. Arg., Flora 65: 335. 1882. Type. Indonesia (Java), Junghuhn 111 (G!).

Graphis treubii Zahlbr., Ann. Crypt. Exot. 1: 129.1928 Holotype. Indonesia (Java), Van Overeem 93 (w!).

Graphis theae Zahlbr. in Handel-Mazzetti, Symb. Sin. 3: 49. 1930. Holotype. China (Yunnan), Handel-Mazzetti 11217 (w!).

DiAgNosis - Thallus corticate, smooth to uneven, yellowish gray. Lirellae erumpent, partly branched, with lateral thalline margin, $1-3 \mathrm{~mm}$ long, $0.1-0.2 \mathrm{~mm}$ broad; labia striate. Excipulum apically carbonized. Hymenium clear. Ascospores 8 per ascus, transversely 7-9-septate, 40$50 \times 7-8 \mu \mathrm{m}$, hyaline. Secondary chemistry: stictic acid.

REMARKS - Graphis vittata is closely related to G. stenotera, from which it differs chiefly in the larger ascospores. More material is required to test whether this difference is consistent. The species was not found in our collections but is present in the type collection of Graphis supertecta.

Graphis xylophaga (R. C. Harris) Lücking, comb. nov. Fig. 21E.

Graphina xylophaga R. C. Harris, Some Florida Lichens: 14. 1990. Holotype. U.S.A., Harris $23900(\mathrm{NY} !)$

DiAGNOSIS-Thallus ecorticate, uneven, white-gray. Lirellae erumpent, rarely branched, with lateral thalline margin, $1-3 \mathrm{~mm}$ long, $0.3-$ $0.5 \mathrm{~mm}$ broad; labia entire. Excipulum laterally carbonized. Hymenium clear. Ascospores 1-2 per ascus, muriform, 65-90 × 20-30 $\mu \mathrm{m}$, hyaline. Secondary chemistry: no substances detected by TLC.

REMARKS-This species is similar to Graphis subliascens but differs by its ecorticate thallus, shorter lirellae with lateral thalline margin, and 1-2-spored asci. Apart from the large, muriform ascospores, it provides a morphological transition between the $G$. insulana group and the $G$. farinulenta aggregate in the $G$. scripta group.

Specimens Seen-COSTA RICA. Cartago: SW slope of Volcán Turrialba, $\mathrm{N}$ of Santa Cruz, Fila Bonilla, along Camino El Trazado, $83^{\circ} 43^{\prime} \mathrm{W}, 10^{\circ} 01^{\prime} \mathrm{N}$, $2100 \mathrm{~m}$, pastureland with relic trees of cloud forest, on young Almus tree trunk, 14 Mar 1985, Sipman 20338 (B, CR). Guanacaste: Carara National Park. Quebrada Bonita Section (Pacífico Central Conservation Area), $84^{\circ} 35^{\prime} \mathrm{W}, 9^{\circ} 47^{\prime} \mathrm{N}, 100 \mathrm{~m}$, lowland moist forest zone, partly disturbed dense primary forest with understory dominated by Erythrochiton gymnanthus, on bark (lower trunk), 18 Jul 2002, Sipman 48381 (B, INB3987189). 


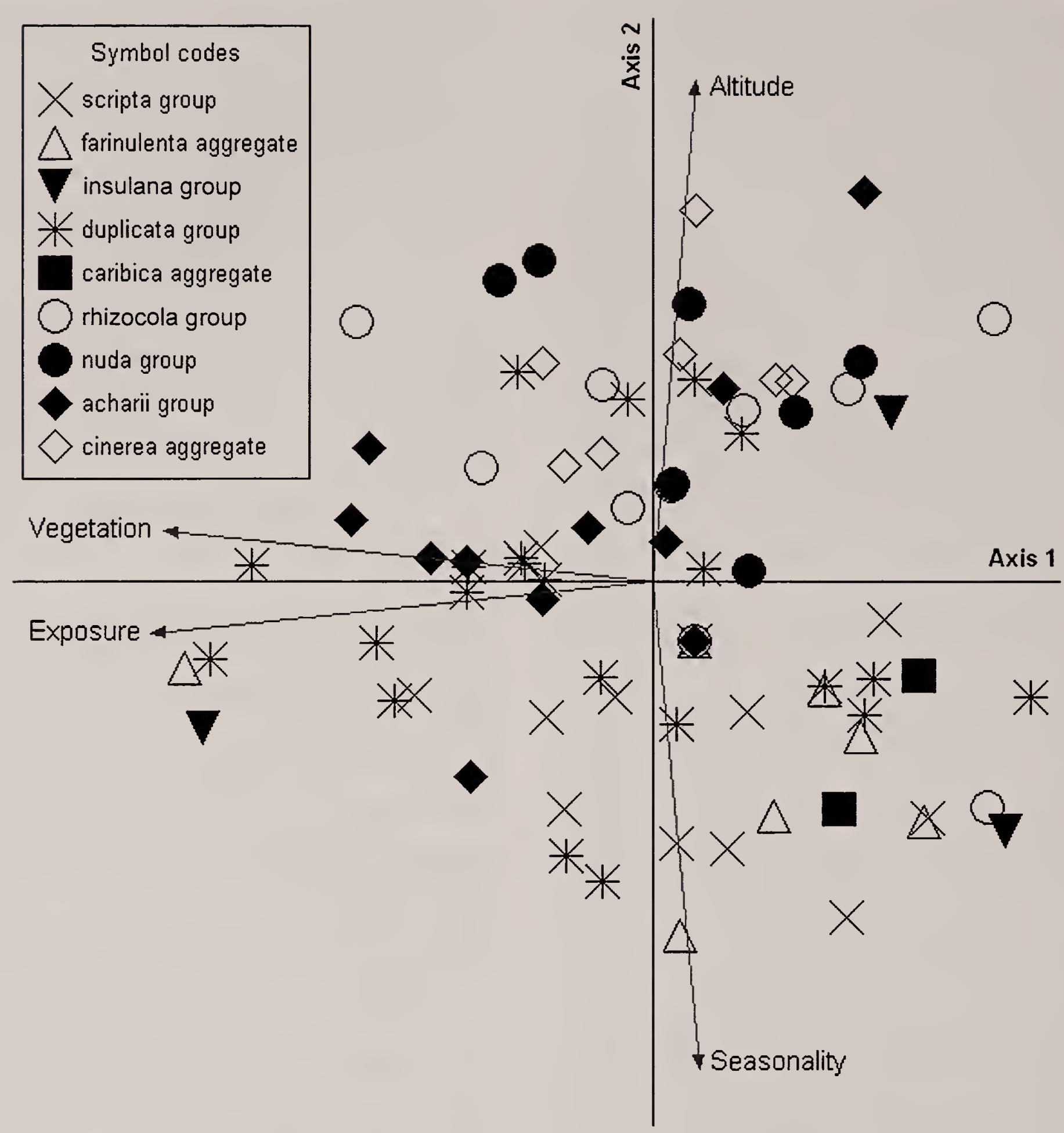

FIG. 26. PCA ordination of 90 species of Graphis according to their weighted average scores corresponding to altitude, seasonality, exposure, and disturbance. Taxa are symbol coded by taxonomic group to display group differences in ecological preferences.

\section{Multivariate Analysis of Habitat and Microhabitat Preferences}

PCA ordination (Fig. 26) shows differential ecological preferences for the different groups of Graphis species, except for the glaucescens aggregate (here subsumed into the scripta group) and the proserpens aggregate (here subsumed into the duplicata group). The group with the widest ecological amplitude and the smallest degree of ecological differentiation is the duplicata group (including the proserpens aggregate), dispersed over almost the entire diagram but not quite reaching the highest altitudinal levels. Members of the scripta group are clearly restricted to the lower part of the diagram, indicating a negative correlation with altitude (preferring lower altitudinal levels) and a positive correlation with seasonality (preferring sites with distinct dry season). The farinulenta aggregate shows even a more pronounced positive correlation with seasonality, most species being typical for semideciduous dry forest. The insulana group is represented by only three species and shows a pattern generally similar to that of the duplicata group, whereas the caribica aggregate closely resembles the ecological preferences of the farinulenta aggregate, being restricted to semideciduous dry forest. Interestingly, in both cases there is a negative correlation with exposure, indicating that under such dry conditions, species prefer shadier microsites than those growing in moist and wet evergreen rain and cloud forest. In general, the species of Graphis studied here show little differentiation on the first axis, which correlates with exposure and disturbance, indicating that most taxa are found in intermediate conditions, that is, semiexposed microsites and 


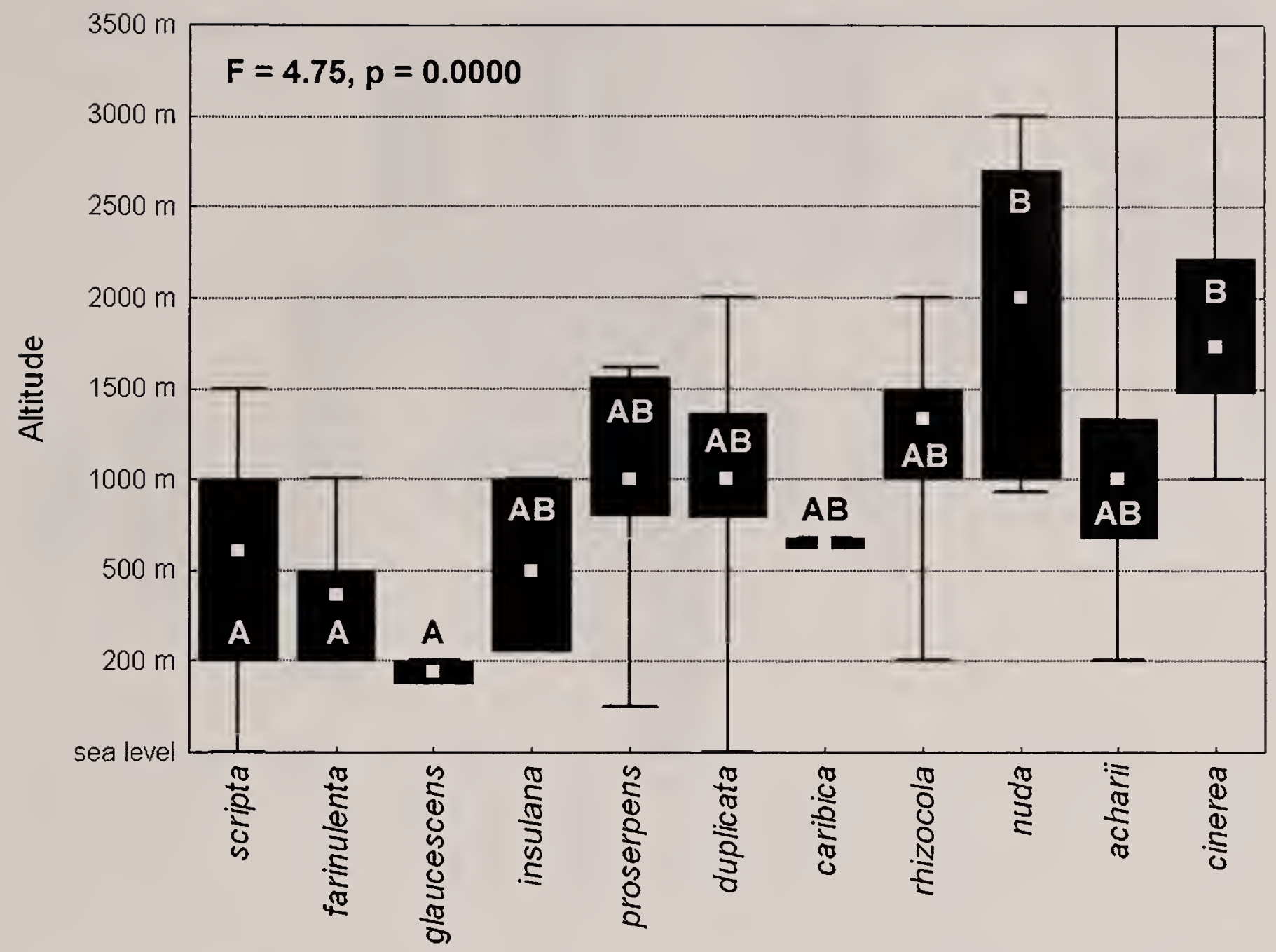

FIG. 27. ANOVA box plot of 90 species of Graphis according their weighted average scores corresponding to altitude. Taxa are arranged into taxonomic groups to display group differences in ecological preferences. Groups with different letters are significantly different from each other; groups with combined letters are intermediate.

partly disturbed or secondary forests. Contrary to the scripta group, the remaining four groups (rhizocola, nuda, acharii, cinerea) show a distinct positive correlation with altitude and a negative correlation with seasonality, indicating preference for higher-altitude sites with high and constant precipitation. The most characteristic high-altitude groups are the nuda group and the cinerea aggregate, while the rhizocola and acharii groups are more typical of midelevations.

The ANOVA confirms the pattern apparent from the PCA ordination and, except for exposure, diplays significant differences between the groups with respect to environmental preferences (Figs. 27-30). Altitudinal differentiation reveals three groupings (Fig. 27): the scripta, farinulenta, and glaucescens groups and aggregates being typical of lowland to lower montane zones $(0-1000 \mathrm{~m})$; the insulana, duplicata, proserpens, caribica, rhizocola, and acharii groups and aggregates being more commonly found at midelevations (750-1500 m); and the nuda group and cinerea aggregate being restricted mostly to high elevations (1000-3000 m). Accordingly, the scripta group and the farinulenta and caribica aggregates are most typical of sites with distinct to strong dry season, whereas the glaucescens aggregate, the insulana group, the duplicata group, and the proserpens aggregate are restrict- ed mostly to evergreen rain forests with a slight to distinct dry season (Fig. 28). The remaining four groups (rhizocola, nuda, acharii, cinerea), prefer sites with a slight dry season only. No significant differences are found among the groups with respect to exposure (Fig. 29), with most species being found in semiexposed to exposed microsites, but significant differences do exist with respect to disturbance (Fig. 30). The farinulenta and caribica aggregates seem to prefer undisturbed to partly disturbed primary forest, which shows that, contrary to the assumption made on the basis of the PCA ordination, it is not exposure but disturbance that restricts the growth of these lichens in their "preferred" habitat: the semideciduous dry forests. The duplicata, proserpens, acharii, and cinerea groups and aggregates, on the other hand, are more typically found in secondary forest and secondary vegetation, probably because no pronounced microsite differences exist between different disturbance levels in their "preferred" habitats: the lowland and lower to upper montane rain forest. The remaining five groups and aggregates (scripta, glaucescens, insulana, rhizocola, nuda) are intermediate as to their disturbance preferences.

Unfortunately, no detailed comparative data exist so far on the ecology of tropical Graphis 


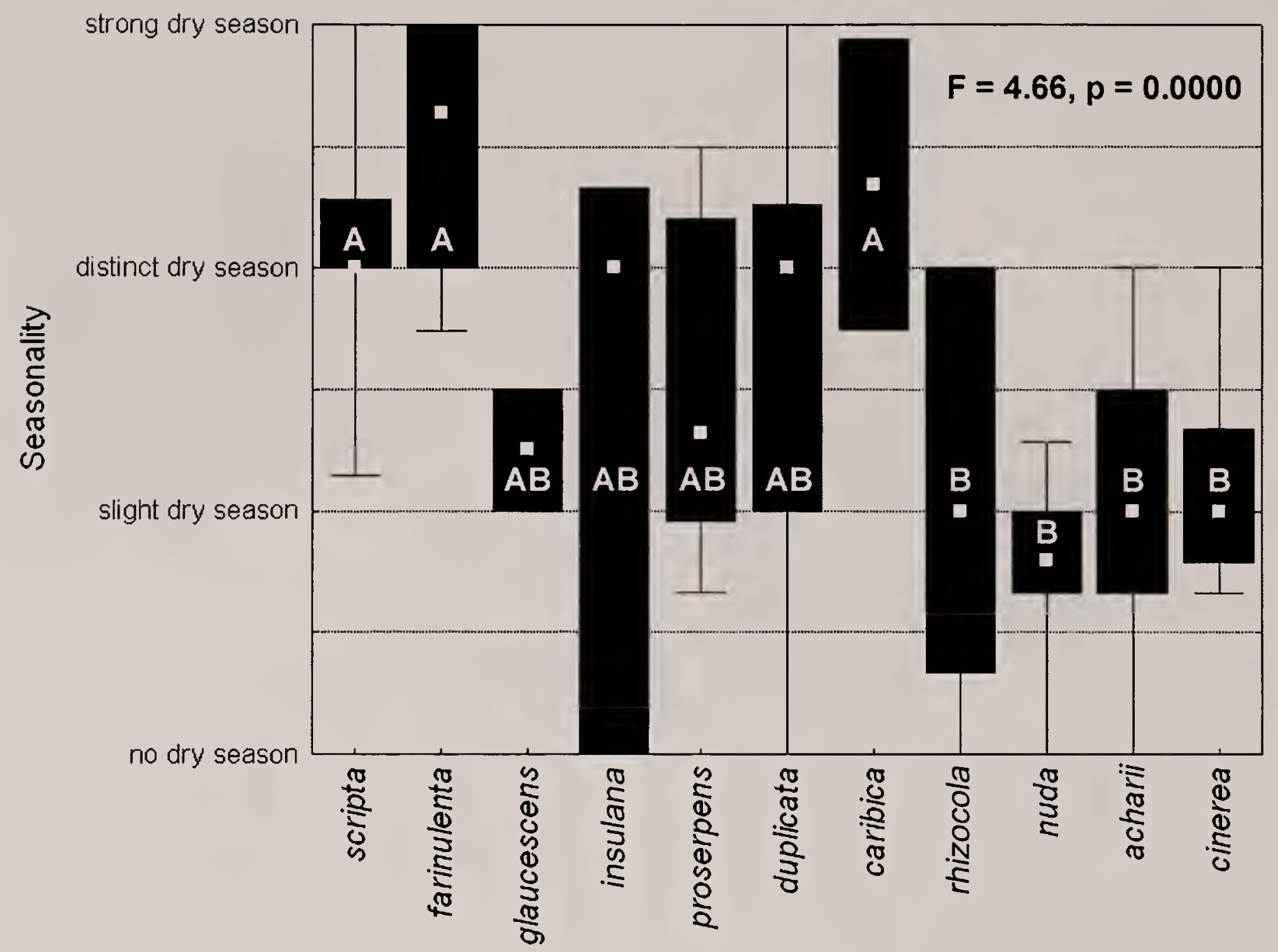

FIG. 28. ANOVA box plot of 90 species of Graphis according their weighted average scores corresponding to seasonality. Taxa are arranged into taxonomic groups to display group differences in ecological preferences. Groups with different letters are significantly different from each other; groups with combined letters are intermediate.

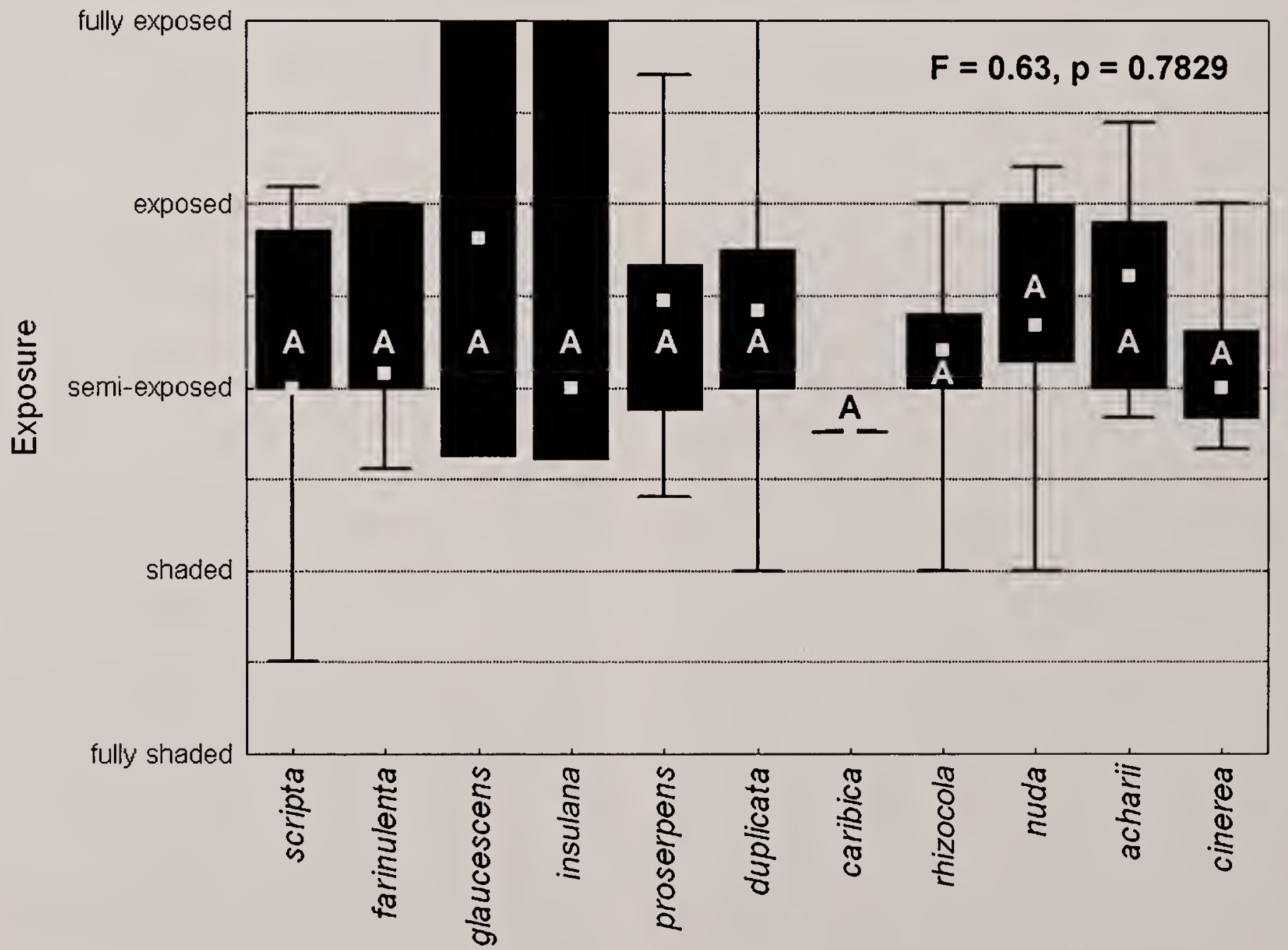

FIG. 29. ANOVA box plot of 90 species of Graphis according their weighted average scores corresponding to exposure. Taxa are arranged into taxonomic groups to display group differences in ecological preferences. Groups with different letters are significantly different from each other; groups with combined letters are intermediate. 


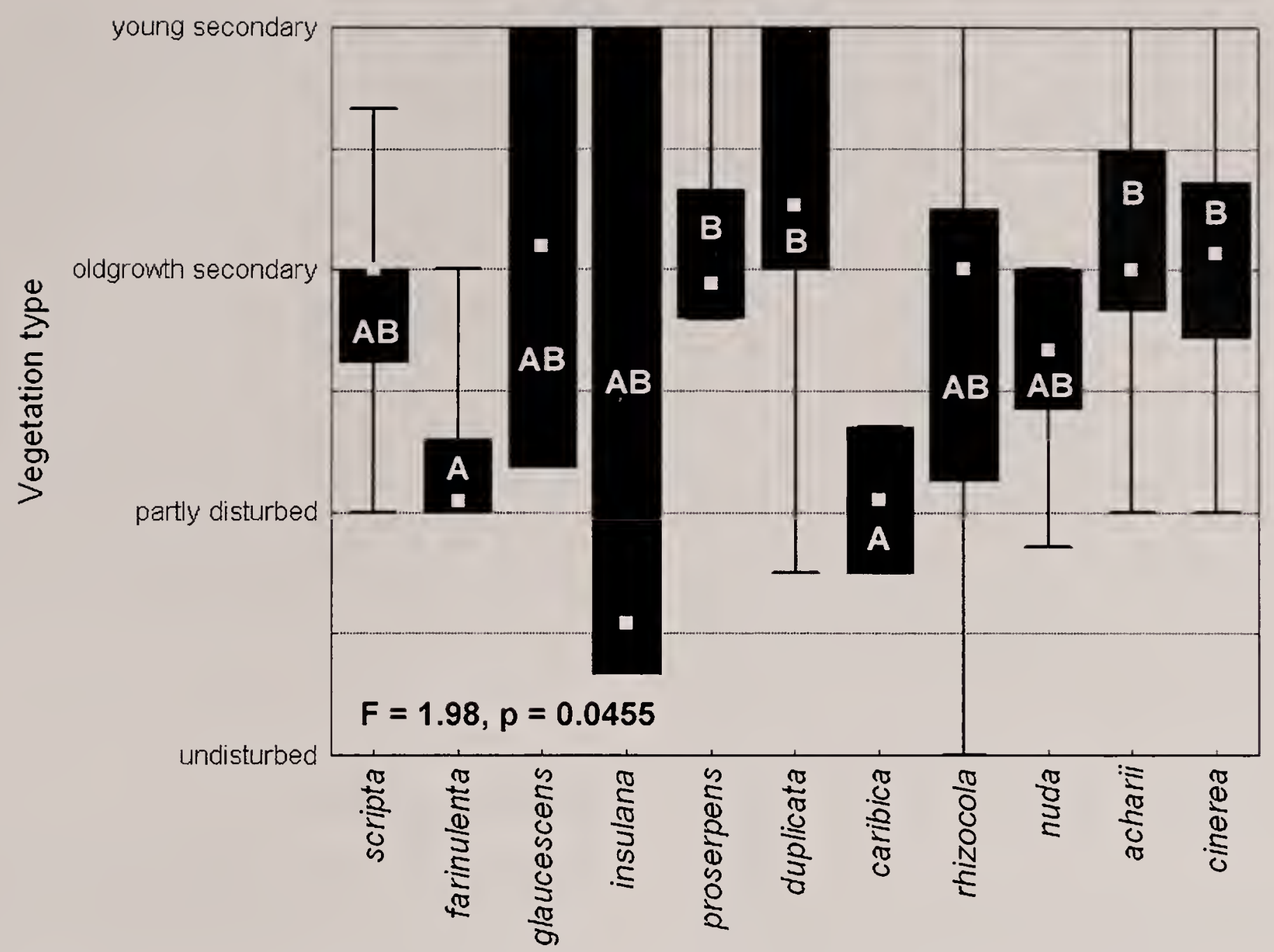

FIG. 30. ANOVA box plot of 90 species of Graphis according their weighted average scores corresponding to disturbance. Taxa are arranged into taxonomic groups to display group differences in ecological preferences. Groups with different letters are significantly different from each other; groups with combined letters are intermediate.

species, and except for the monograph on Australian species by Archer (2006), the scattered observations in other papers are obscured by the application of a previous, artificial species concept uniting unrelated taxa within the same genus and separating closely related species between different genera (Wirth \& Hale, 1963, 1978; Sipman \& Harris, 1989; Staiger, 2002). The present data show that the bulk of species in Graphis s.str. is found at midelevations in vegetation with slight to distinct dry season, that is, the lower montane rain forest, in semiexposed to exposed microsites (lower canopy, forest margin, free-standing trees), and in partly disturbed and secondary forests. Thus, contrary to many Thelotremataceae (Hale, 1974b, 1978, 1981; Sipman \& Harris, 1989; Rivas Plata et al., 2008), the genus Graphis is not a typical element of the shady lowland rain forest understory. This correlates with the fact that most species of Graphis have a white, light-reflecting thallus strongly encrusted with calcium oxalate crystals and provided with a cartilaginous cortex (Staiger, 2002), a thallus morphology otherwise rare in Graphidaceae and very rarely found in Thelotremataceae (Hale 1974b, 1978, 1981; Frisch et al., 2006).

The results of this analysis correlate with morphological and anatomical variation within
Graphis and with the evolutionary history of the genus since closely related groups display similar ecological preferences and morphological features. For example, the rhizocola, nuda, acharii, and cinerea groups and aggregates are characterized chiefly by large lirellae with massive, completely carbonized excipulum as well as large ascospores. It is difficult to interpret these characteristics as ecological adaptations to higher elevations, and it seems equally likely that shared ancestry is accountable for the found patterns, the shared characters and ecology then supporting the notion that these groups are closely related. The same is true of the duplicata group and the proserpens aggregate, which virtually have the same ecological preferences and differ only in excipulum carbonization, with the latter nested within the former (Lücking, 2008b). Also, the scripta group and the farimulenta and glaucescens aggregates behave similar with respect to several environmental parameters.

On the other hand, certain characters found among the different groups are suggestive of ecological adaptations. Yellow to orange pigments on the lirellae are restricted to the rhizocola and acharii groups, both typical of lower to upper montane forests. Such pigments 
are known to filter UV radiation (Rikkinen, 1995; Nybakken et al., 2004), although in these cases their function is obscured by the fact that the lichens have massive, carbonized excipula that should protect the hymenia from UV damage. The black, sessile lirellae of the nuda group, apart from protecting against UV radiation, might assist in converting light energy to maintain a certain temperature level within the ascomata when developing ascospores. Similarly, the strong type B inspersion found mainly in the cinerea aggregate could be an adaptation to prevent frost damage of the hymenium. Species of the farinulenta and caribica aggregate, both most typically found in semideciduous dry forest, are characterized either by ecorticate, farinose thalli and pruinose labia or by yellow-green thalli atypical of Graphis species. The ecological significance of these characteristics remains unknown, but the farinose thalli and pruinose labia of species in the farinulenta aggregate suggest a role with respect to temperature and water regime.

\section{Acknowledgments}

The TICOLICHEN biodiversity inventory in Costa Rica was supported by a grant from the National Science Foundation (DEB 0206125 to The Field Museum, PI Robert Lücking) and by funds from the World Bank to the Instituto Nacional de Biodiversidad (INBio). We greatly appreciate the support of the Sistema Nacional de Áreas de Conservación (SINAC) and the Ministerio de Ambiente y Energía (MINAE) in receiving the necessary collection permits and the assistance of Álvaro Herrera and Milagros Mata from INBio in obtaining these permits. Daniela Lizano (Universidad de Costa Rica); Eida Fletes, Ronald Rodríguez, and Eduardo Alvarado (INBio); Susan Will-Wolf, Marie Trest, and Matt Nelsen (University of Wisconsin-Madison, USA); and Bill Buck (New York Botanical Garden, USA), François Lutzoni and Jolanta Miadlikowska (Duke University, USA), and Martin Grube (University of Graz, Austria) participated in the field campaigns, and their valuable support and company are warmly acknowledged.

Special thanks go to the Firfer family, Chicago, for their enthusiastic support of this monograph and for giving us the possibility to publish the color plate.
The extensive studies of types and other material necessary for this work would not have been possible without the help and assistance of curators and staff at the herbaria in $\mathrm{FH}, \mathrm{G}, \mathrm{H}, \mathrm{S}$, TUR, UPS, US, and w. Bettina Staiger, Klaus Kalb, Alan Archer, and Richard Harris provided useful information and discussions on many aspects of Graphis taxonomy that helped to put the Costa Rican taxa in place. Bettina Staiger and Emmanuël Sérusiaux are especially acknowledged since they spent countless hours as external reviewers not only improving this manuscript with their expert comments but also finding even the smallest typos in the text.

\section{Literature Cited}

ABratis, M., AND G. WÖRNER. 2001. Ridge collision, slab-window formation, and the flux of Pacific asthenosphere into the Caribbean realm. Geology, 29: $127-130$.

ADAWADKAR, B., AND U. MAKHIJA. 2007. New species and new records of Graphis from India with partially carbonized exciples and transseptate ascopores. Mycotaxon, 99: 303-326.

Aptroot, A. 2002. New and interesting lichens and lichenicolous fungi in Brazil. Fungal Diversity, 9: $15-45$.

AptroOt, A., AND H. J. M. SipMAN. 2007. A new Schistophoron (Graphidaceae) from Costa Rica. Bibliotheca Lichenologica, 96: 21-24.

Aptroot, A., L. Umaña, J. L. Chaves, and M. T. TREST. 2006. A first assessment of the Ticolichen bio-diversity inventory in Costa Rica: Three new squamulose genera (Lecanorales: Ramalinaceae and Pilocarpaceae). Journal of the Hattori Botanical Laboratory, 100: 617-623.

Aptroot, A., R. LÜCKInG, H. J. M. Sipman, L. UMAÑA, AND J.-L. CHAVES. 2008. A first assessment of the lichen biodiversity inventory in Costa Rica: Pyrenocarpous lichens with bitunicate asci. Bibliotheca Lichenologica, 97: 1-162.

ArCHER, A. W. 1999. The lichen genera Graphis and Graphina (Graphidaceae) in Australia 1. Species based on Australian type specimens. Telopea, 8: 273-295.

2000. The lichen genera Phaeographis and Phaeographina (Graphidaceae) in Australia. 1: Species based on Australian type specimens. Telopea, 8: $461-475$.

2001a. New taxa and new reports in the lichen family Graphidaceae (Ascomycotina) from Australia. Mycotaxon, 80: 367-374.

2001b. The lichen genera Phaeographis and Phaeographina (Graphidaceae) in Australia 2: Phaeographina-New reports and new species. Telopea, 9: 329-344. 
2001c. The lichen genera Phaeographis and Phaeographina (Graphidaceae) in Australia 3: Phaeographis-New reports and new species. Telopea, 9: 663-677.

2001d. The lichen genus Graphis (Graphidaceae) in Australia. Australian Systematic Botany, 14: 245-271.

- 2001e. The lichen genus Graphina (Graphidaceae) in Australia: New reports and new species. Mycotaxon, 77: 153-180.

- 2003a. Graphina streblocarpa, Graphina subserpentina (Graphidaceae, lichenised Ascomycota) and their synonyms. Mycotaxon, 86: 31-36.

2003b. New species in the lichen family Graphidaceae (Ascomycota) from Australia and the Solomon Islands. Mycotaxon, 88: 143148.

2005. Australian species in the genus Diorygma (Graphidaceae). Australasian Lichenology, 56: 11-12.

2006. The lichen family Graphidaceae in Australia. Bibliotheca Lichenologica, 94: 1-191.

2007. Additional lichen records from Australia 63. Australas. Lichenol., 61: 6-7.

Awasthi, D. D. 1991. A key to the microlichens of India, Nepal and Sri Lanka. Bibliotheca Lichenologica, 40: 1-340.

Bowers, F. D. 1974. The mosses reported from Costa Rica. Bryologist, 77: 150-171.

Breuss, O. 2000. Flechten aus Costa Rica. I. Regenwald der Österreicher (Bosque Esquinas). Linzer Biologische Beiträge, 32: 1043-1051.

2001. Flechten aus Costa Rica. II. Linzer Biologische Beiträge, 33: 1025-1034.

2004. Flechten aus Costa Rica. III. Linzer Biologische Beiträge, 36: 77-80.

Brodo, I. M., S. Duran Sharnoff, ANd S. SharnOFF. 2001. Lichens of North America. Yale University Press, New Haven, Connecticut.

CÁCERES, M. E. S. 2007. Corticolous crustose and microfoliose lichens of northeastern Brazil. Libri Botanici, 22: 1-168.

Carranza, J., And G. M. Mueller, eds. 1996. Fungi of Costa Rica: Selected Studies on Ecology and Biodiversity. Revista de Biologia Tropical, 44(Suppl. 4): $1-152$

Chaves, J. L., R. Lücking, H. J. M. Sipman, L. UMAÑA, AND E. NAVARRO. 2004. A first assessment of the ticolichen biodiversity inventory in Costa Rica: The genus Dictyonema (Polyporales: Atheliaceae). Bryologist, 107: 242-249.

Coen, E. 1991. Clima, pp. 31-41. In Janzen, D. H., ed., Historia Natural de Costa Rica. Editorial de la Universidad de Costa Rica, San José, Costa Rica.

Dalton, R. 2006. Biodiversity: Cashing in on the rich coast. Nature, 441: 567-569.

Dauphin, G., S. R. Gradstein, A. BerneckerLÜCKING, AND M. MORALES. 1998. Additions to the hepatic flora of Costa Rica. Lindbergia, 23: 74-80.

Di Stéfano, J. F., V. N. IElsen, J. HoOmans, AND L. A. FourniER. 1996. Regeneración de la vegetación arbórea en una pequeña reserva forestal urbana del premontano húmedo, Costa Rica. Revista de Biología Tropical, 44: 575-580.

DoDGE, C. W. 1933. The foliose and fruticose lichens of Costa Rica I. Annals of the Missouri Botanical Garden, 20: 373-467.

1964. Some lichens of tropical Africa. IV: Dermatocarpaceae to Pertusariaceae. Nova Hedwigia Beiheft, 12: 1-282.

EGAN, R. S. 1990. Changes to the "Fifth Checklist of the Lichen-Forming, Lichenicolous and Allied Fungi of the Continental United States and Canada." Edition II. The Bryologist, 93: 211-219.

Elix, J. A., AND P. M. MCCARThy. 1998. Catalogue of the lichens of the smaller Pacific islands. Bibliotheca Lichenologica, 70: 1-361.

ERnst, G., AND M. HAUCK. 1994. Die Gattung Phaeographis (Ach.) Müll. Arg. in Deutschland. Herzogia, 10: 39-59.

FÉE, A. L. A. 1824. Essai sur les Cryptogames des Ecorces Exotiques Officinales. Didot Perè et Fils, Paris.

1874. Matériaux pour une flore lichénologique du Brésil, II. Les Graphidées. Bulletin de la Société Botanique de France, 21: 21-32.

Fernández, F. A., J. D. Rogers, Y.-M. JU, S. M. HUHNDORF, AND L. UMAÑA. 2004. Paramphisphaeria costaricensis gen. et sp. nov. and Pachytrype rimosa sp. nov. from Costa Rica. Mycologia, 96: 175-179.

Fournier, L. O. 1985. Ecología y Desarollo en Costa Rica. Editorial Universidad Estatal a Distancia, San José, Costa Rica.

Frisch, A., K. KAlb, AND M. GRubE. 2006. Contributions towards a new systematics of the lichen family Thelotremataceae. Bibliotheca Lichenologica, 92: 1-556.

GÁmez, R., T. LOVEJOY, R. SOlorzano, AND D. JANZEN. 1997. Costa Rican all-taxa survey. Science, 277: $18-19$.

GARCíA, R. 1997. Biología de la Conservación y Áreas Silvestres Protegidas: Situación Actual y Perspectivas en Costa Rica. 1 Ed. INBio, Santo Domingo de Heredia, Costa Rica.

Gómez, L. D. 1986. Vegetación de Costa Rica. Editorial Universidad Estatal a Distancia, San José, Costa Rica.

_-_ 1996. Basidiomycetes de Costa Rica. 9. Xerocomus, Chalciporus, Pulveroboletus, Boletellus, Xanthoconium (Agaricales, Boletaceae). Revista de Biologia Tropical, 44(Suppl. 4): 59-90.

GowARD, T. 1999. The Lichens of British Columbia, Illustrated Keys. Part 2, Fruticose Species. British Columbia Ministry of Forests, Victoria.

Gradstein, S. R., A. LÜCKing, M. I. Morales, AND G. DAUPHIN. 1994. Additions to the hepatic flora of Costa Rica. Lindbergia, 19: 73-86.

Gradstein, S. R., AND I. Holz. 2005. Diversidad de las briofitas en los paramos de Costa Rica, pp. 361-374. In Kappelle, M., et al., ed., Páramos de Costa Rica. INBio, Santo Domingo, Costa Rica. 
Groombridge, B. 1994. Biodiversity Data Sourcebook. World Conservation Press, Cambridge.

Grube, M., R. LÜCKing, ANd L. UMAÑA. 2004. A new isidiate species of Arthonia (Ascomycota: Arthoniaceae) from Costa Rica. Mycologia, 96: 1159-1162.

HaLE, M. E. JR. 1974a. Studies on the lichen family Thelotremataceae. 2. Phytologia, 27: 490-501.

1974b. Morden-Smithsonian Expedition to Dominica: The lichens (Thelotremataceae). Smithsonian Contributions to Botany, 16: 1-46.

1978. A revision of the lichen family Thelotremataceae in Panama. Smithsonian Contributions to Botany, 38: 1-60.

- 1981. A revision of the lichen family Thelotremataceae in Sri Lanka. Bulletin of the British Museum (Natural History), Bot. Ser., 8: 227-332.

Halling, R. E. 1996. Boletaceae (Agaricales): Latitudinal biodiversity and biological interactions in Costa Rica and Colombia. Revista de Biologia Tropical, 44(Suppl. 4): 111-114.

Halling, R. E., ANd G. M. Mueller. 2005. Common Mushrooms of the Talamanca Mountains, Costa Rica. New York Botanical Garden Press, Bronx, New York.

HARris, R. C. 1990. Some Florida Lichens. Publ. by the Author, Bronx, New York.

1995. More Florida Lichens. Including the 100 Tour of the Pyrenolichens. Publ. by the Author, Bronx, New York.

HartshorN, G. S. 1991. Plantas, pp. 35-46 in Janzen, D. H., ed., Historia natural de Costa Rica. Editorial de la Universidad de Costa Rica, San José, Costa Rica.

Hawksworth, D. L., ANd M. A. Sherwood. 1981. Proposals for nomina conservenda and rejicienda for ascomycete names (lichenized and non-lichenized). Taxon, 30: 338-348.

HAYwARD, G. C. 1977. Taxonomy of the lichen. families Graphidaceae and Opegraphaceae in New Zealand. New Zealand Journal of Botany, 15: 565-584.

Herrera, W. 1985. Clima de Costa Rica (Vegetación y clima de Costa Rica, Vol. 2). Editorial Universidad Estatal a Distancia, San José, Costa Rica.

Hilje, L. Q. 2006. Karl Hoffmann: Naturalista, Médico y Héroe Nacional. 1. Ed. INBio, Santo Domingo de Heredia, Costa Rica.

Holdridge, L. 1947. Determination of world plant formations from simple climatic data. Science, 105: 367-368.

1967. Life Zone Ecology. Tropical Science Center, San Jose, Costa Rica.

1982. Ecologia Basada en Zonas de Vida. Centro Cientifico Tropical. IICA, San Jose, Costa Rica.

Holdridge, L., W. C. Grenke, W. H. Hatheway, T. LIANG, AND J. A. TOSI. 1971. Forest Environments in Tropical Life Zones: A Pilot Study. Pergamon Press, Oxford.

Holz, I., AND S. R. GRadSTEIN. 2005. Phytogeography of the bryophyte floras of oak forests and páramo of the Cordillera de Talamanca, Costa Rica. Journal of Biogeography, 32: 1591-1609.

Holz, I., J. HeINRICHS, A. SCHÄFER-VERIVIMP, AND S. R. Gradstein. 2001. Additions to the hepatic flora of Costa Rica III. Cryptogamie Bryologie, 22: 255-273.

Huhndorf, S. H., F. A. Fernández, A. N. Miller, AND D. J. LODGE. 2003. Neotropical ascomycetes 12. Mirannulata samuelsii gen. et sp. nov. and $M$. costaricensis sp. nov., new taxa from the Carribean and elsewhere. Sydowia, 55: 172-180.

JOYCE, C. 1992. Western medicine men return to the field: Tropical forest loss and fast lab techniques are propelling the search for therapeutic phytochemicals. Bioscience, 42: 399-403.

JANZEN, D. H., ed. 1974. Costa Rican Natural History. University of Chicago Press, Chicago.

Jørgensen, P. M., P. W. JAmes, AND C. E. JARvis. 1994. Linnaean lichen names and their typification. Botanical Journal of the Linnean Society, 115: 261-405.

Kalb, K., And B. Staiger. 2000. Dyplolabia Massalongo. Monographie einer vergessenen Flechtengattung. Hoppea, 61: 409-422.

Kalb, K., B. Staiger, And J. A. Elix. 2004. A monograph of the lichen genus Diorygma-A first attempt. Symbolae Botanicae Upsalienses, 34(1): 133-181.

Kappelle, M., and H. J. M. Sipman. 1992. Foliose and fruticose lichens of Talamanca montane Quercus forests, Costa Rica. Brenesia, 37: 51-58.

Kurokawa, S., ed. 2003. Checklist of Japanese Lichens. National Science Museum, Tokyo http:// home.hiroshima-u.ac.jp/lichen/cklist.htm.

LÜCKING, R. 1992. Foliicolous lichens-A contribution to the knowledge of the lichen flora of Costa Rica, Central America. Beih. Nova Hedwigia, 104: $1-179$.

1995. Biodiversity and conservation of foliicolous lichens in Costa Rica. Mitteilungen der Eidgenössischen Forschungsanstalt für Wald, Schnee and Landschaft, 70: 63-92.

1999. Líquenes foliícolas de la Estación Biológica La Selva, Costa Rica: Inventario, comunidades y comparación floristica de tipos de vegetación. Revista de Biologia Tropical, 47: 287-308.

2003. TICOLICHEN_-The Costa Rican Lichen Biodiversity Inventory. http://www.fieldmuseum. org/ticolichen.

2008a. Foliicolous Lichenized Fungi. Flora Neotropica Monograph 103 (in press).

2008b. The taxonomy of the genus Graphis sensu Staiger: A first attempt towards a world monograph. Lichenologist 40 (in press).

LÜCKING, R., AND D. L. HAwKSWORTH. 2007. Names for lichen-forming fungi introduced by Ciferri and Tomaselli are illegitimate and not available for use, except for three cases. Taxon, 56: 1274-1284.

LÜCKInG, R., AND E. Rivas PlatA. 2008. Clave y guía ilustrada para géneros de Graphidaceae. Glalia (in press). 
LÜCKING, R., H. J. M. SiPMAN, AND L. UMAÑa. 2004. TICOLICHEN-The Costa Rican lichen biodiversity inventory as a model for lichen inventories in the tropics, p. 32. In Randlane, T., and A. Saag, eds., Lichens in Focus Tartu University Press, Tartu.

Lǘcking, R., A. Aptroot, L. Umaña. J. L. Chaves. H. J. M. Sipman, AND M. P. Nelsen. 2006. A first assessment of the Ticolichen biodiversity inventory in Costa Rica: The genus Gyalideopsis (Ostropales: Gomphillaceae). Lichenologist, 38: 131-160.

Lücking, R., A. Aptroot, J. L. Chaves, H. J. M. SIPMAN, AND L. UMAÑA. 2007a. A first assessment of the TICOLICHEN biodiversity inventory in Costa Rica: The genus Coccocarpia (Peltigerales: Coccocarpiaceae). Bibliotheca Lichenologica, 95: 429-457.

LÜCKING, R., H. J. M. SIPMAN, L. UMAÑA, J.-L. Chaves, AND H. T. Lumbsch. 2007b. Aptrootia (Dothideomycetes: Trypetheliaceae), a new genus of pyrenocarpous lichens for Thelenella terricola. Lichenologist, 39: 187-193.

LÜCKING, R., K. Kalb, B. Staiger, ANd J. MCNeill. 2007c. Proposal to conserve the name Phaeographis, with a conserved type, against Creographa, Ectographis, Flegographa, Hymenodecton, Platygramma. Pyrochroa. and Pyrographa (Ascomycota: Ostropales: Graphidaceae), along with notes on the names Graphina and Phaeographina. Taxon, 56: 1296-1299.

LÜCking, R., R. Del Prado, H. T. LumbsCh, S. Will-Wolf, A. Aptroot, H. J. M. Sipman, L. UMAÑA, AND J. L. Chaves. 2008a. Phylogenetic patterns of morpho-chemical characters and reproductive mode in the Heterodermia obscurata group in Costa Rica (Ascomycota, Physciaceae). Systematic Biodiversity, 6: 31-41.

LÜCKING. R., A. M. FRYDAY, AND A. J. JOHNSTON. 2008b. The Graphidaceae collected by Henry A. Imshaug in the West Indies and South America. Fieldiana (Botany) (in press).

MAKHIJA, U.. AND B. ADAWADKAR. 2005a. Some additions to the Graphidaceae in the Andaman Islands. India. Mycotaxon, 91: 347-352.

. 2005b. Some new species of Graphis (lichenised Ascomycota) from the Andaman and Nicobar Islands of India. Mycotaxon. 91: 369-379.

MAKHIJA, U., A. DUBE, B. ADAWADKAR, AND G. CHITALE. 2005. Five trans-septate species of Hemithecium from India. Mycotaxon, 93: 365-372.

Mangold, A., M. P. Martin, R. LÜCKING, AND H. T. LUMBSCH. 2008. Molecular phylogeny places Thelotremataceae within Graphidaceae (Ascomycota: Ostropales). Taxon. 57 (in press).

Marshall, J. S., B. D. Idleman. T. W. Gardner, AND M. D. FISHER. 2003. Landscape evolution within a retreating volcanic arc, Costa Rica. Central America. Geology, 31: 419-422.

MATA, M. 1999. Macrohongos de Costa Rica. Vol. 1. INBio. Santo Domingo de Heredia. Costa Rica.

Mata. M., R. E. Halling. and G. M. Mueller. 2003. Macrohongos de Costa Rica. Vol. 2. INBio. Santo Domingo de Heredia. Costa Rica.

McCune. B., J. B. Grace. And D. L. Urban. 2002. Analysis of Ecological Communities. MjM Software, Gleneden Beach. Oregon.
MCCune. B., AND M. J. MefFord. 1999. PC-ORD. Multivariate Analysis of Ecological Data, Version 4.0. MjM Software, Gleneden Beach. Oregon.

Meyen, J., ANd J. Flotow. 1843. Lichenes Exotici (Observationes in itinere circum terram institutae (1830-1832): Lichenes. Nova Acta Physico-Medica Academiae Caesareae Leopoldino-Carolinae Naturae Curiosum. 19(Suppl.): 209-232.

Morales, C. O. 2002. Ecce homo. scientia clarus: Luis Fournier Origgi (1935-2002). Lankesteriana, 5: 1-2.

Mueller, G., AND R. E. Halling. 1995. Evidence for high biodiversity of Agaricales (Fungi) in neotropical montane Quercus forests, pp. 303-312. In Churchill, S. P. et al., ed.. Biodiversity and Conservation of Neotropical Montane Forests. New York Botanical Garden Press. Bronx, New York.

Müller ARgoviensis, J. 1880a. Lichenologische Beiträge, X. Flora. 63: 17-24.

1880b. Lichenologische Beiträge, X (Schluss) Flora. 63: 40-45.

1887. Graphideae Féeanae inclus. trib. affinibus nec non Graphidaea exoticae Acharii. El. Friesii et Zenkeri e novo studio speciminum originalium expositae et in novam dispositionem ordinatae. Mémoires de la Société de Physique et d'Histoire Naturelle de Genève, 29(8): 1-80.

1891. Lichenes [Th. Durand et H. Pittier. Primitiae Florae Costaricensis]. Bulletin de la Société Royale de Botanique de Belgique. 30: 49-97.

1893a. Lichenes. Séconde énumération. Th Durand et H. Pittier. Primitae Florae Costaricensis] Bulletin de la Société Royale de Botanique de Belgique. 32: 122-173.

1893b. Lichenes Wilsoniani. seu lichenes a cl. rev. F. R. M. Wilson in Australiae prov. Victoria lecti. Bulletin de l'Herbier de Bossier. 1: 33-65.

1967. Gesammelte Lichenologische Schriften. Band I. Lichenologische Beitrage 1876-1891. Hue s Index Alphabeticus 1899. J. Cramer. Lehre.

NAGARKAR. M. B.. AND P. G. PATWARDHAN. 1982 Notes on some lichens from North East India IV: genus Graphis. Biovigyanam, 8: 125-131.

NAKANISHI, M.. H. KaSHIWADANI. AND K. H. MOON 2003. Taxonomical notes on Japanese Graphidaceae (Ascomycotina). including some new combinations. Bulletin of the National Science Museum (Tokyo). Series B (Botany). 29(2): 83-90.

NASH. T. H. III. B. D. RYAN. C. GRIES. AND F BUNGARTZ. eds. 2002. Lichen Flora of the Greater Sonoran Desert Region. I. Lichens Unlimited. Arizona State University. Tempe. Arizona

NASH. T. H. III. B. D. RYAN. P. DIEDERICH. C. GRIES, AND F. BUNGARTZ. eds. 2004. Lichen Flora of the Greater Sonoran Desert Region. Vol. 2. Lichens Unlimited, Arizona State University. Tempe. Arizona.

Nelsen. M. P.. R. LüCking. J. L. Chaves, H. J. M. SipMAN. L. UMAÑA. AND E. NAvarRo. 2006. A first assessment of the Ticolichen biodiversity inventory in Costa Rica: The genus Haematomma (Lecanorales: Lecanoraceae). Lichenologist. 38: 251-262.

Nelsen. M. P.. R. LÜCKing, L. UMaña. M. T. TRest. S. Will-Wolf, J. L. Chaves. And A. Gar-Gas. 
2007. Multiclavula ichthyoclavula (Fungi: Basidiomycota: Cantharellales: Clavulinaceae), a remarkable new basidiolichen from Costa Rica. American Journal of Botany, 94: 1289-1296.

Nybakken, L., K. A. Solhaug, W. Bilger, and Y. GAUSLAA. 2004. The lichens Xanthoria elegans and Cetraria islandica maintain a high protection against uv- $B$ radiation in Arctic habitats. Oecologia, 140: $211-216$

Nylander, W. 1868. Synopsis Lichenum Novae Caledoniae. Bulletin de la Societe Linneenne de Normandie, 2: 39-140.

OBAndo, V. 2002. Biodiversidad en Costa Rica: Estado del Conocimiento y Gestión. INBio, Santo Domingo de Heredia, Costa Rica.

PATwardhan, P. G., AND C. R. Kulkarni. 1976. Some additions to the lichen flora of India. IV: Graphis and Graphina (family Graphidaceae). Biovigyanam, 2: 123-132.

1977. Some additions to the lichen flora of India. V. Genera Phaeographis and Phaeographina (family: Graphidaceae). Current Science, 46: 720-721.

- 1979a. Some new taxa of the family Graphidaceae from Western Ghats, southwestern India. Norwegian Journal of Botany, 26: 45-52.

1979b. The lichen genus Phaeographina (family Graphidaceae) in the Western Ghats, Southwestern India. Indian Journal of Botany, 2: 132-143.

PATWARdhan, P. G., AND M. B. NAGARKAR. 1979. Notes on some lichens from North East India I: family Graphidaceae. Biovigyanam, 5: 131-138.

Pentecost, A. 2003. A preliminary investigation into ascospore characters in the Graphidaceae and Opegraphaceae. British Lichen Society Bulletin, 92: 35-39.

Pichler, H., AND R. WeYl. 1975. Magmatism and crustal evolution in Costa Rica (Central America). Geologische Rundschau, 64: 457-475.

Poelt, J. 1974. Bestimmungsschlüssel Europäischer Flechten. J. Cramer, Vaduz.

Porras, A., And B. Villareal. 1985. Deforestación en Costa Rica. Editorial Costa Rica, San José.

Purvis, O. W., B. J. Coppins, D. L. Hawksworth, P. W. JAMES, AND D. M. MoORE, eds. 1992. The Lichen Flora of Great Britain and Ireland. Natural History Museum Publications \& British Lichen Society, London.

REDINGER, K. 1935. Die Graphidineen der ersten Regnell'schen Expedition nach Brasilien 1892-94. III. Graphis und Phaeographis, nebst einem Nachtrage zu Graphina. Arkiv for Botanik, 27A(3): 1-103.

RIKKINEN, J. 1995. What's behind the pretty colours? A study on the photobiology of lichens. Bryobrothera, 4: 1-239.

Rivas Plata, E., R. LÜcking, A. Aptroot, H. J. M. Sipman, J. L. Chaves, L. Umaña, AND D. Lizano. 2006. A first assessment of the Ticolichen biodiversity inventory in Costa Rica: the genus Coenogonium (Ostropales: Coenogoniaceae), with a worldwide key and checklist and a phenotype-based cladistic analysis. Fungal Diversity, 23: 255-321.

Rivas Plata, E., R. Lücking, and H. T. Lumbsch. 2008. When family matters: An analysis of Thelo- tremataceae (lichenized Ascomycota: Ostropales) as bioindicators of ecological continuity in tropical rainforests. Biodiv. Cons., 17 (in press).

Rogers, J. D., A. Hidalgo, F. A. Fernández, And S. M. HuHNDORF. 2004. Ophiorosellinia costaricensis gen. et sp. nov., a xylariaceous fungus with scolecosporous ascospores. Mycologia, 96: 172-174.

SANTESSON, R. 1993. The Lichens and Lichenicolous Fungi of Sweden and Norway. SBT-Förlaget, Lund.

SiPMAN, H. J. M., AND R. C. HARRIS. 1989. Lichens, pp. 303-309. In Lieth, H., and M. J. A. Werger, eds., Tropical Rain Forest Ecosystems Biogeographical and Ecological Studies (Ecosystems of the World 14B). Amsterdam: Elsevier.

StaIGer, B. 2002. Die Flechtenfamilie Graphidaceae. Studien in Richtung einer natürlicheren Gliederung. Bibliotheca Lichenologica, 85: 1-526.

Staiger, B., AND K. KalB. 1999. Acanthothecis and other graphidioid lichens with warty periphysoids or paraphysis-tips. Mycotaxon, 73: 69-134.

Staiger, B., AND M. Grube. 2004. Molecular phylogeny and character evolution in Graphidaceae (Ostropomycetidae), p. 8. In Randlane, T., and A. Saag, eds., Lichens in Focus. Tartu University Press, Tartu.

Staiger, B., K. Kalb, And M. Grube. 2006. Phylogeny and phenotypic variation in the lichen family Graphidaceae (Ostropomycetidae, Ascomycota). Mycological Research, 110: 765-772.

UmañA, L., AND H. J. M. Sipman. 2002. Líquenes de Costa Rica-Costa Rica Lichens. INBio, Santo Domingo de Heredia, Costa Rica.

UMAÑA, L., H. J. M. SIPMAN, AND R. LÜCKING. 2002. Preliminary checklist of lichens from Costa Rica. Version 1.2. http://www.fieldmuseum.org/ticolichen/ checklist.html.

VAINIO, E. A. 1921. Lichenes Insularum Philippinarum III. Acta Societatis pro Fauna et Flora Fennica, 15(6): 1-368.

Wirth, M., AND M. E. Hale, JR. 1963. The lichen family Graphidaceae in Mexico. Contributions from the U.S. National Herbarium, 36: 63-119.

1978. Morden-Smithsonian Expedition to Dominica: The lichens (Graphidaceae). Smithsonian Contributions to Botany, 40: 1-64.

WirTh, V. 1995. Die Flechten Baden-Württembergs. Ulmer, Stuttgart.

Wolseley, P. A., AND B. Aguirre-Hudson. 1991. Lichens as indicators of environmental change in the tropical forests of Thailand. Global Ecology and Biogeography Letters, 1: 170-175.

Wolseley, P. A., C. MoncriefF, And B. AguirreHUDSON. 1994. Lichens as indicators of environmental stability and change in the tropical forests of Thailand. Global Ecology and Biogeography Letters, 4: 116-123.

ZAHLBRUCKNER, A. 1930. Lichenes (Übersicht über sämtliche bisher aus China bekannten Flechten), pp. 1-254 in Handel-Mazetti, H., Symbolae Sinicae. Botanische Ergebnisse der Expedition der Akademie der Wissenschaften in Wien nach Südwest-China 1914-1918, Vol. 3. Springer, Wien. 


\section{Index to Taxa}

Accepted taxa are in roman type, with principal page entries where taxa are treated in boldface. Synonyms are italicized. New taxa and new combinations are in boldface. Pages where taxa are keyed out are indicated in [brackets], pages with figures with an asterisk*, and pages with table information with the $\wedge^{\wedge}$-symbol.

Acanthothecis $9,10^{\wedge}$

acharii (Graphina) 55

acharii (Graphis) $11,13,15,16,17,18^{\wedge}, 20,21^{\wedge}, 21^{\wedge}$, $22^{\wedge}, 22^{\wedge}, 27^{\wedge},[34], 52^{*}, \mathbf{5 5}, 57,59,61,67,72,72$, $74,81,85,89,89,90,93,93,98,109,116,118^{*}$, $119,119^{*}, 120^{*}, 121,121^{*}$

acharii var. subducens (Graplina) $21^{\wedge}$

acharii var. subintegra (Graplina) $18^{\wedge}, 85$

acharii var. subintegra (Graphis) 56

acharii var. vestita (Graphina) $21^{\wedge}$

acharii var. vestitoides (Graphis) 116

acromelaena (Graphina) 19^, 21^, 97

acrophaea (Graphina) 97

acroplraea (Graplisis) 19^

acuminata (Graphis) 19^, 98

adpressa (Graphis) $12^{*}, 14^{*}, 15,18^{\wedge}, 26^{\wedge},[30], 42^{*}, \mathbf{5 6}$, 95, 98, 99

adtenuans (Graphis) 85

afzelii (Dyplolabia) $21^{\wedge}$

afzelii (Graphis) 21

agminalis (Graphina) 21^

albida (Graphis) 21^ 104

albinula (Graphis) 21

albimula var. clausa (Graphis) $21^{\wedge}$

albissina (Graphis) 18^,77

alborosella (Graplis) 21^

Allographa 55

altamirensis (Graphis) $18^{\wedge}, 26^{\wedge},[34], 53 *, 57,60$

analoga (Graplina) 80

araloga (Graphis) $18^{\wedge}, 80,81$

analoga var. monophora (Graphina) 21^, 93

analoga var. subradiata (Graphina) 92

analoga var. subradiata (Graphis) 19^, 92

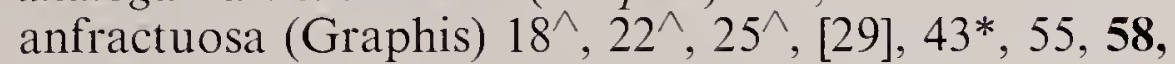
72

anfractuosa (Scaphis) 55, 58

angolensis (Graphis) 79

anguillaefornlis var. infecunda (Graphis) 19^, 102, 103

anguilliformis (Graphis) 19^,102, 103

anguina (Graphina) 21^, 55

anguina (Ustalia) 55

anguinum (Thalloloma) $21^{\wedge}, 55$

angustata (Graphis) 18^, 26^, [34], 44*, 58, 111

angustata var. denudata (Graphis) $18^{\wedge}, 75$

anmulata (Graphis) 19^, 97

Anomalographis 10

Anomomorpha $10^{\wedge}, 11$

antillarum (Graphina) 59

antillarum (Graphis) 18^ , 24^, [32], 49*, 59, 59, 61, 96, 98

antillarum var. namilensis (Graphis) 18^,80

aperiens (Graphis) 64

apertella (Graphis) 64, 64, 64, 107, 108

aquilonia (Graphinla) 59

aquilonia (Graphis) 18^, 26^, [34], 46*, 59, 116 argentata (Graphis) $12^{*}, 18^{\wedge}, 22^{\wedge}, 26^{\wedge}$, [30], [34], 53*, $57, \mathbf{5 9}, 60,61,76,79,98,101,111$

assimilis (Graphis) 21^ $, 69,70,104$

atrolabiata (Graphina) $21^{\wedge}$

atrolabiata (Graphis) 18^,75

Aulacographa 15, 55

bakeri (Graphina) 21

bakeri (Graphis) 62, 108

balbisii (Graphina) 21

balbisii (Hemithecium) 21

balbisii var. monospora (Graplina) 21^

batanensis (Graphis) 18^,68

bettinae (Graphis) $18^{\wedge}, 26^{\wedge},[30], 45^{*}, 60,60,61,61,84$, 111

bicrenatula (Graphis) 70

bicrenulata (Graphis) 18^, 70

bipartita (Graphina) 61

bipartita (Graphis) 18^, 24^, [32], 49*, 59, 61

bougainvillei (Graphis) 18^,68

brachycarpa (Graphis) 104, 104

britannica (Graphis) 116

bulacana (Graphis) 18^,60, 79

caesia (Graplis) 18^,79

caesiella (Graphis) $18^{\wedge}, 21^{\wedge}, 25^{\wedge},[29], 39^{*}, 61,62,68$, $79,88,106,108$

caesiocarpa (Graphis) $18^{\wedge}, 25^{\wedge},[30], 43^{*}, 62,82$

caesioglauca (Graphis) 18^,79

caesiopruinosa (Platygramme) $21^{\wedge}, 21^{\wedge}$

candidata (Graphis) 22^,103

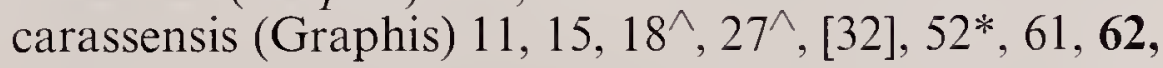
84

Carbacanthographis $10^{\wedge}, 11,20,95$

carbocarpa (Graphina) 19^,90

caribica (Graphis) $9,18^{\wedge}, 20,24^{\wedge},[32], 37^{*}, 63,77,86$,

$118,118^{*}, 119,119^{*}, 120^{*}, 121^{*}, 122$

catherinae (Graphis) 19^,108, 109

celtidis (Graphis) 18^,87

cerviculata (Phaeographis) 19^, 116

ceylandica (Graphis) 18^, 68

chapadana (Pallidogramme) 9

chapadana (Plhaeographina) 9

chapadanum (Hemithecium) 9

chlorocarpa (Graphina) 21

chlorocarpoides (Graplisis) 9

chlorocarpoides (Hemithecium) 9

chlorocarpoides (Pallidogramme) 9

chlorocarpoides (Phaeographina) 9

chlorocarpum (Hemithecium) $21^{\wedge}, 22^{\wedge}, 22^{\wedge}, 100$

chlorotica (Graphis) 15, 18^, 24^, [32], 37*, 63, 100

chondroplaca (Graphis) $12^{*}, 18^{\wedge}, 24^{\wedge},[29], 40 *, 55,64$, $77,88,107,108^{\wedge}, 112$

chromothecia (Graphis) 64

chrysentera (Graphis) 9 
chrysentera (Phaeographina) 9

chrysenteron (Henithecium) 9, $21^{\wedge}$

chrysenteron (Leucogramma) 9

chrysenteron (Pallidogramme) 9, 22

chrysocarpa (Graplinia) 64

chrysocarpa (Graphis) 8, 15, 17, $18^{\wedge}, 21^{\wedge}, 21^{\wedge}, 22^{\wedge}$, $26^{\wedge},[28], 36^{*}, 55,60,64,74,75,76,91,98,110$ chrysocarpa (Opegrapha) 64

chrysocarpa (Phaeographina) 65

cicatricosa (Glyphis) 5*

cinerea (Graphis) $5^{*}, 15,18^{\wedge}, 20,26^{\wedge},[33], 45^{*}, 57,61$, $66,67,76,84,92,98,101,111,118^{*}, 119,119^{*}$, $120^{*}, 121,121^{*}, 122$

cinereoides (Graphis) 18^, 60

cleistoblephara (Graphis) $18^{\wedge}, 26^{\wedge},[31], 54^{*}, 67,68$, 85,99

cleistostomma (Graphina) 21^

cleitops (Graphis) 95

collatinensis (Graphina) $21^{\wedge}$

colliculosa (Graphis) 22

conferta (Graphis) $19^{\wedge}, 22^{\wedge}, 102,103,117$

confluens (Diorygma) $21^{\wedge}, 21^{\wedge}, 21^{\wedge}, 21^{\wedge}, 22^{\wedge}$

confluens (Graphina) 21

consanguinea (Graphina) 67,90

consanguinea (Graphis) $18^{\wedge}, 27^{\wedge},[34], 52^{*}, 67,68,90$

cooperta (Graphis) 19^,102

copelandii (Graphis) 85

crebra (Graphis) $22^{\wedge}, 64,64,77,107,108^{\wedge}$

croceum (Ctesium) 55, 64

crystallifera (Graphina) 93

crystallifera (Graphis) 19^, 90

Ctesium 55

cuiabensis (Graphis) $18^{\wedge}, 82$

curta (Graphis) 18^, 56

Cyclographina 9

dehiscens (Schistostoma) 18^, 55, 64

dendrogramma (Graphis) $5^{*}, 11,18^{\wedge}, 25^{\wedge},[29], 39^{*}$, $62,68,79,108$

deserpens (Graphis) 81

diaphoroides (Graphis) 18^ 87

dichotoma (Graphina) 21

dichotoma (Graphis) $11,12^{*}, 18^{\wedge}, 21^{\wedge}, 22^{\wedge}, 25^{\wedge},[33]$ $50 *, 72,73,102$

difformis (Sarcographa) 5*

dimidiata (Graphina) 68

dimidiata (Graphis) $18^{\wedge}, 24^{\wedge},[28], 47^{*}, 68$

Diorygma $9,10^{\wedge}, 11,17,22,79,113$

disserpens (Graphina) 69

disserpens (Graphis) $18^{\wedge}, 19^{\wedge}, 21^{\wedge}, 24^{\wedge},[33], 47^{*}, 69$, 96, 100, 114

dividens (Graplina) 21^

dolichographa (Graphis) 80

dracenae (Graphis) $18^{\wedge}, 21^{\wedge}, 25^{\wedge},[30], 41^{*}, 69,70,95$, 113

dupaxana (Graphis) 18^, 25^, [34], 41*, 70, 104, 105

duplicata (Graphis) 13, 16, 18^ $, 20,22^{\wedge}, 22^{\wedge}, 25^{\wedge},[33]$ $38^{*}, 69,70,70,70,71,71,72,72,74,82,83,86,89$, $89,93,100,102,105,110,118,118^{*}, 119,119^{*}$, $120^{*}, 121,121 *$

duplicata var. australasiatica (Graphis) $18^{\wedge}, 63,105$

duplicata var. nana (Graphis) 22

duplicata var. sublaevis (Graphis) $22^{\wedge}$

duplicatoinspersa (Graphis) $18^{\wedge}, 24^{\wedge},[33], 40^{*}, 71,72$ durandi (Graphis) 22

dussii (Graphis) 11, 17, 20, 67, 81, 99
Dyplolabia $9,10^{\wedge}, 11$

elegans (Aulacographa) 55, 72

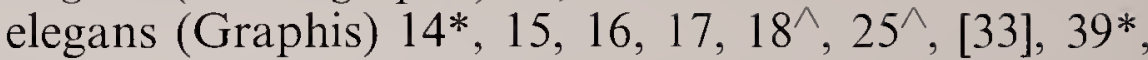
$55,55,72,89,89,99$

elegans (Opegrapha) 72

elegantis (Graphidomyces) 55

elongata (Graphis) 73, 102

elongatoradians (Graphina) 18^, 72, 73

elongatoradians (Graphis) 102

emersa (Graphis) $18^{\wedge}, 25^{\wedge},[30], 43 *, 73,117$

endoschiza (Graphina) 19^, 102

endoschiza (Graphis) 102

epiglauca (Graphina) 21^

epiglaucum (Diorygma) $21^{\wedge}$

errescens (Graphina) 21^, 73

farinulenta (Graphis) 5* $11,17,18^{\wedge}, 20,25^{\wedge},[29]$, [33] $38^{*}, 73,74,88,97,108,109,117,118,118^{*}, 119$ $119^{*}, 120^{*}, 121,121^{*}, 122$

ferruginea (Graphis) $108^{\wedge}$

filiformis (Graphis) 18^,87

firferi (Graphis) $18^{\wedge}, 26^{\wedge},[28], 36^{*}, 74,74,76,76,113$

Fissurina $10^{\wedge}$

flabellans (Graphis) $19^{\wedge}, 109$

flavens (Graphis) $18^{\wedge}, 26^{\wedge},[31], 42^{*}, 75,95,106,106$, 109

flavicans (Graphis) 89

flavoaltamirensis (Graphis) $18^{\wedge}, 26^{\wedge},[28], 36^{*}, 74,75$, 76

flavominiata (Graphis) $18^{\wedge}, 26^{\wedge},[28], 36^{*}, 74,76$

flexibilis (Graphis) 18^,58

foliicola (Graphis) 18^, 77

fournierii (Graphis) 9, 18^ $, 26^{\wedge},[34], 51^{*}, 63,76,77$

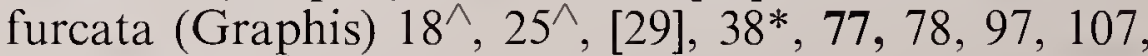
$108,108^{\wedge}, 109$

geraensis (Graphis) $18^{\wedge}, 20,22^{\wedge}, 25^{\wedge},[30], 41^{*}, \mathbf{7 8}, 88$, 113,117

glaucella (Graphis) 22^

glaucescens (Graphis) $11,12^{*}, 17,18^{\wedge}, 22^{\wedge}, 24^{\wedge},[28]$, $[32], 37^{*}, 60,78,79,113,118,119,119^{*}, 120^{*}, 121$ $121^{*}$

Glaucinaria 9

glaucocaesia (Graphis) $18^{\wedge}, 22^{\wedge}, 79$

glaucoleucoides (Graphina) $21^{\wedge}$

glaucovirens (Graphis) 114

globosa (Graphis) 11, 17, 91

globosa (Opegrapha) 91

globosa (Topeliopsis) $19^{\wedge}, 91$

Glyphis $9,10^{\wedge}, 22$

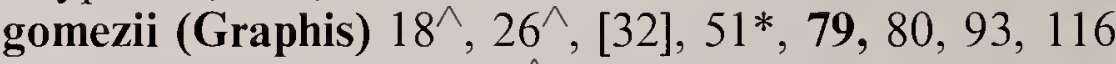

gracilescens (Graphis) 19^,98

gracilis (Graphina) $21^{\wedge}, 80$

gracilis (Graphis) $18^{\wedge}, 25^{\wedge}$, [29], 50*, 80, 81

gracilis (Opegrapha) 80

grammitica (Graphis) 22^,73

granulosa (Graphina) 81

granulosa (Graphis) $18^{\wedge}, 27^{\wedge}$, [31], [34], 54*, 81, 105

Graphidomyces 55

Graphina 8, 9, 55, 65

Graphis 8, 9, $10^{\wedge}$

gregmuelleri (Graphis) $18^{\wedge}, 24^{\wedge},[32], 42^{*}, 81,92$

guimarana (Graphis) 18^, 64

Gymnographopsis $10^{\wedge}$ 
liaemographa (Graphina) 21^

haemographum (Thalloloma) $21^{\wedge}$

haleana (Graphis) 16, 18^ $, 25^{\wedge},[33], 39^{*}, \mathbf{8 2}, 89,110$

llandelii (Graphis) 18^, 87

hemispherica (Graphis) 91

Hemithecium 9, $10^{\wedge}, 11,59$

heteroclita (Sarcographa) 5*

lieteroplaca (Graplina) $21^{\wedge}, 84$

heteroplacoides (Graphina) $18^{\wedge}, 67,90$

heteroplacoides (Graphis) 68

liascens (Graphina) 67

hiascens (Graphis) 67, 85

hiascens (Opegrapha) 67

hieroglyphicum (Diorygma) $22^{\wedge}, 22^{\wedge}$

hologlauca (Graplina) 21^

homograplia (Graplitina) 21

hyphosa (Graphis) $18^{\wedge}, 25^{\wedge},[30], 42^{*}, 82,88$

hypocrellina (Graphis) $16,18^{\wedge}, 25^{\wedge},[28], 36^{*}, 83$

ignea (Graphina) $21^{\wedge}$

ignea (Graphis) 18^,65

illinata (Graphina) 83

illinata (Graphis) $18^{\wedge}, 21^{\wedge}, 22^{\wedge}, 27^{\wedge}$, [32], 52*, 56, 62,

83, 86, 91, 103, 105

illota var. leopoldensis (Graphis) 19^, 102

immersa (Graphina) 82

immersa (Graphis) $22^{\wedge}, 82$

immersella (Graphis) $108^{\wedge}$

immersicans (Graphis) 18^ $, 69,70$

immersoides (Graphis) 81, 82, 92

includens (Graphis) 18^, 67, 90

includens (Phaeographina) 67

innata (Graphina) 21^ 62

inspersa (Graphis) 19^, 72, 115

inspersostictica (Graphis) $18^{\wedge}, 26^{\wedge},[30], 54^{*}, 84$

insulana (Graphina) 84

insulana (Graphis) $13,14^{*}, 16,17,18^{\wedge}, 20,21^{\wedge}, 21^{\wedge}$, $25^{\wedge},[29], 50^{*}, 70,71,72,80,84,86,110,111,117$,

$118,118^{*}, 119,119^{*}, 120^{*}, 121^{*}$

interstes (Graphina) $21^{\wedge}$

intricata (Graphis) $22^{\wedge}, 70,114$

intricata f. meizospora (Graphis) $18^{\wedge}, 42 *, 82$

inturgescens (Graphina) 85

inturgescens (Graphis) $18^{\wedge}, 27^{\wedge},[32], 51^{*}, 56, \mathbf{8 5}, 98$

inversa (Graphis) $108^{\wedge}$

irradians (Graphis) $18^{\wedge}, 68$

junghuhnii (Diorygma) $21^{\wedge}, 21^{\wedge}$

kakaduensis (Graphis) 62, 62

Kalbographa $10^{\wedge}$

kermesina (Grapliis) $18^{\wedge}, 65$

kjellbergii (Graphis) 19^, 105

labyrinthica (Sarcographa) $5^{*}$

Leiorreuma $5^{*}, 10^{\wedge}, 15$

leprevostii (Helminthocarpon) $21^{\wedge}$

leprographa (Graphis) $18^{\wedge}, 26^{\wedge},[30], 54^{*}, 86$

leptocarpa (Graphis) $18^{\wedge}, 24^{\wedge}$, [29], 40*, 63, 70, 78, 86, $108^{\wedge}, 115$

leptocarpa var. invita (Grapluis) $18^{\wedge}, 69$

leptoclada (Graphis) $18^{\wedge}, 25^{\wedge},[33], 38^{*}, 70,71,86,104$

Leucogramma 9

leuconephala (Graphis) 22^

leucoparyplia (Graphis) 19^,90 librata (Graphis) $12^{*}, 18^{\wedge}, 25^{\wedge},[29], 39 *, 58,70,78$, 87, $108^{\wedge}, 115$

lineola (Graphis) $18^{\wedge}, 24^{\wedge},[29], 40^{*}, 67,70,78,86,87$, $87,108^{\wedge}, 115$

lineola var. chondroplaca (Graplis) 64, 64, 64

lineola var. marginata (Grapliis) 112

litoralis (Graphis) $16,18^{\wedge}, 25^{\wedge},[29], 39^{*}, 82, \mathbf{8 8}, 108^{\wedge}$

longula (Graphis) $18^{\wedge}, 26^{\wedge},[34], 42^{*}, 70,83,86,89,93$ lopingensis (Graphis) 18^,70

lucifica (Graphis) 16, 19^ $, 25^{\wedge},[33], 39^{*}, 82,89$

lumbricina (Graphis) 15, 17, 19^ $, 26^{\wedge},[31]$, [34], 45*, 72, 89, 104

lumbschii (Graphis) 67

lumbschii var. deficiens (Graphina) 19^,99

lumbschii var. deficiens (Graphis) 99

lussuensis (Graphis) 18^,70

lutea (Allographa) 55, 65

lutea (Graphis) 55, 65

macella (Graphina) 90

macella (Graphis) $19^{\wedge}, 27^{\wedge}$, [34], 52*, 56, 68, 90, 92, 93 macgregorii (Graphis) $18^{\wedge}, 85$

malmei (Graphina) 65

marcescens (Carbacanthographis) $21^{\wedge}, 74$

marcescens (Graphina) 21

marginata (Graphis) $19^{\wedge}, 19^{\wedge}, 26^{\wedge},[31], 45^{*}, 64,90$, $106,112,116$

marginifera (Graphis) $19^{\wedge}, 105$

Melaspilea 11, 20

mendax (Graphina) 21^

mexicana (Graphis) $12^{*}, 19^{\wedge}, 27^{\wedge},[31], 52^{*}, 84,91,94$ mexicanum (Thelotrema) 91

miniata (Graphis) 19^, 26^, [28], 36*, 65, 91, 91, 110

mirabilis (Graphis) $19^{\wedge}, 24^{\wedge},[32], 48^{*}, 82,92,98$

modesta (Graphis) 68

montagnei (Graphina) 55

montagnei (Thecaria) 83

moultonii (Grapliss) 18^,70

multisulcata (Graphina) 92

multisulcata (Graphis) $19^{\wedge}, 26^{\wedge},[34], 51^{*}, 77,92,100$, 102

muscicola (Graphina) 91

muscicola (Graphis) 19^, 84, 91

myrtacea (Graphina) 93

myrtacea (Graphis) $11,14^{*}, 16,19^{\wedge}, 21^{\wedge}, 27^{\wedge},[34], 52^{*}$, $68,80,89,90,93,115,116$

nuda (Graphina) 93

nuda (Graphis) $5^{*}, 11,11,13,17,19^{\wedge}, 19^{\wedge}, 20,20,26^{\wedge}$,

[31], 51*, 57, 58, 72, 73, 78, 93, 94, 95, 99, 105, 112,

$117,118^{*}, 119,119^{*}, 120^{*}, 121,121 *, 122$

nudaeformis (Graphis) 19^, 20, 26^ $,[30], 44^{*}, 89,94$

nylanderi (Graphis) 85

nylanderiana (Graplina) $18^{\wedge}, 67$

obtectula (Graplina) $21^{\wedge}$

ocliracea (Grapliis) 110

ochracea (Phaeographis) 19^

Opegraplia 55, 77

orientalis (Graphis) $18^{\wedge}, 85$

oryzaecarpa (Graphis) $19^{\wedge}, 27^{\wedge},[31], 52^{*}, 94$

ovata (Graphis) 14*, 16, 19^, 25^ $,[30], 41^{*}, 57,93,95$

oxyclada (Graphis) $17,19^{\wedge}, 20,25^{\wedge},[30], 41^{*}, 75,78$, 95, 106 
pachypleura (Graphina) $18^{\wedge}, 56$

Pallidogramme 9, $10^{\wedge}$

palmicola (Graphina) 85

palmyrensis (Graphis) 78, $108^{\wedge}$

paradisserpens (Graphis) $19^{\wedge}, 24^{\wedge},[33], 47^{*}, 69,96,100$ paraserpens (Graphis) 19^, 24^, [33], 50*, 69, 96, 102 parilis (Graplina) 97

parilis (Graphis) $19^{\wedge}, 21^{\wedge}, 24^{\wedge},[32], 49^{*}, 59,96,97$, 100

pavoniana (Graphis) $19^{\wedge}, 25^{\wedge},[29], 38^{*}, 73,97,108$

peralbida (Graphina) 61

peralbida (Graphis) 18^,61

persicina (Graphis) 83

perstriatula (Graphis) 19^, 24^, [32], 49*, 59, 69, 96, 97, 100

Phaeographina 8, 65

Phaeographis $8,9,10^{\wedge}, 15,20,22,63,83,99$

Phaeographopsis $10^{\wedge}$

phaeospora (Graphis) $19^{\wedge}, 22^{\wedge}, 26^{\wedge},[34], 53^{*}, 56,57$, $59,60,60,92,98$

pittieri (Graphis) 14*, 15, 16, 19^, 25^ $,[30], 42^{*}, 98,99$ plagiocarpa (Graphis) $11,11,19^{\wedge}, 20,26^{\wedge}$, [31], 46*, $67,81,85,88,99$

platycarpa (Graphis) $19^{\wedge}, 24^{\wedge},[33], 48^{*}, 96,99,102$

platycarpella (Graphis) 22^,56

platycarpoides (Graphis) $18^{\wedge}, 59$

Platygramme $10^{\wedge}, 99$

Platythecium $10^{\wedge}, 11$

Pliariona 55

plicosa (Opegrapha) 65

plicosum (Hemithecium) 65

plumierae (Graphis) 108

plurispora (Graphina) 100

plurispora (Graphis) $19^{\wedge}, 26^{\wedge},[34], 51^{*}, 77,93,100,101$

poitaei (Diorygma) $21^{\wedge}, 21^{\wedge}, 21^{\wedge}, 21^{\wedge}, 113$

poitaei (Graphina) 21

polillensis (Graphis) 79

polyschizans (Graphis) $19^{\wedge}, 98$

proserpens (Graphis) 19^,20, 24^, [32], 37*, 63, 63, 96 ,

100, 102, 118, 119, 119*, 120*, 121, 121*

prosiliens (Phaeographina) 99

prosiliens (Thecographa) 99

pseudanaloga (Graphina) $21^{\wedge}, 56$

pseudocinerea (Graphis) $19^{\wedge}, 26^{\wedge},[34], 53^{*}, 57,60,101$

pseudoserpens (Graphis) $19^{\wedge}, 21^{\wedge}, 25^{\wedge},[33], 47^{*}, 101$, 102

pseudoserpentina (Graphina) 110

pseudoserpentina (Graphis) 19

pseudosophistica (Graphis) 18^, 67,90

pseudosophistica var. plurispora (Graphina) 100

puiggarii (Graphina) 55, 102, 102

puiggarii (Graphis) $19^{\wedge}, 22^{\wedge}, 22^{\wedge}, 25^{\wedge}$, [33], 50* $, 55,71$, 101,102

pyrrhocheiloides (Graphis) 69, 107, 108^

quassiicola (Thecaria) $21^{\wedge}$

ramificans (Sarcographa) 5*

reniforme (Diorygma) $21^{\wedge}$

reniformis (Graphina) $21^{\wedge}$

renschiana (Graphina) $18^{\wedge}, 80$

rhizocola (Graphis) $5^{*}, 11,12^{*}, 13,14^{*}, 15,17,19^{\wedge}, 20$, $21^{\wedge}, 22^{\wedge}, 22^{\wedge}, 22^{\wedge}, 22^{\wedge}, 26^{\wedge},[31], 44^{*}, 56,58,59$, $61,74,76,84,90,94,95,102,103,108,109,113$, $118^{*}, 119,119^{*}, 120^{*}, 121,121^{*}$

rhizocola (Opegrapha) 102 ridigula (Graphis) 71

rigidula (Graphis) $18^{\wedge}, 86$

rimulosa (Graphis) $15,19^{\wedge}, 21^{\wedge}, 25^{\wedge},[34], 41^{*}, 69,83$, 86, 97, 104, 109, 113

rimulosa (Opegrapha) 71, 86, 104

rimulosa var. brachycarpa (Graphis) 19^, 104

rimulosa var. pulverulenta (Graphis) $22^{\wedge}$

rimulosa var. subduplicata (Graphis) $22^{\wedge}$

rimulosa var. tetraspora (Graphis) $19^{\wedge}, 89$

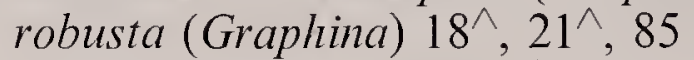

rockii (Graphis) 19^, 24^, [32], 37* , 63, 105, 109

rubricosa (Graphis) 18^,65

rudescens (Grapliss) 18^,84

rufopallens (Graphina) $21^{\wedge}$

rufopallidum (Hemithecium) $21^{\wedge}$

rufula (Graphis) 22^,103

rugulosa (Graphina) $21^{\wedge}, 81$

ruiziana (Graphina) 105

ruiziana (Graphis) $14^{*}, 15,16,19^{\wedge}, 26^{\wedge},[31], 51^{*}, 93$, 105, 112

ruiziana (Opegrapha) 105

rustica (Graphis) 19^ $9^{\wedge} 6^{\wedge},[31], 75,90,105,106,112$, 116

Sarcographa $10^{\wedge}, 15,22$

Sarcographina $10^{\wedge}$

sauroidea (Graphis) 16, 19^, 26^, [31], 43*, 106

scaphella (Graphis) 67

Scaphis 55

schiffneri (Graphis) $19^{\wedge}, 25^{\wedge},[33], 39^{*}, 106$

Schistophoron $10^{\wedge}$

Schistostoma 55

schizograpta (Graphis) $18^{\wedge}, 70,70$

scripta (Graphis) 11, 13, 15, 17, 19^ $, 20,25^{\wedge},[29], 38^{*}$, $55,64,69,71,72,73,77,78,86,87,88,95, \mathbf{1 0 6}$, $107,108^{\wedge}, 112,113,114,117,118,118^{*}, 119,119^{*}$, $120^{*}, 121,121^{*}$

scripta var. commatiformis (Graphis) $22^{\wedge}$

scriptus (Lichen) 106

scyphulifera (Glyphis) 5*

semiaperta (Graphis) 64

seminuda (Graphis) $5^{*}, 17,19^{\wedge}, 26^{\wedge},[31], 42^{*}, 73,97$, 108, 109, 109

seminuda var. sublaevis (Graphis) 19^, 108, 109

serpens (Graphis) 19^,102

sierraleonensis (Graphina) 18^, 85

sikkimensis (Graphis) 19^,100

sitiana (Graphis) 19^, 25^, [30], 41*, 82, 108, 109, 113

Solenographa 9

sophisticá (Graphina) 99

sophistica (Graphis) 19^, 59, 99

sophisticella (Graphina) 21

spodoplaca (Graphis) 19^, 115

stenotera (Graphis) $19^{\wedge}, 24^{\wedge},[32], 37^{*}, 109,117$

stipitata (Graphis) 108

streblocarpa (Graphina) 85

streblocarpa (Graphis) 110

striatula (Graphis) $15,19^{\wedge}, 25^{\wedge},[33], 38^{*}, 82,83,86$, 104, 109

striatula var. sublaevis (Graphis) $22^{\wedge}$

striatula var. substellaris (Graphis) $19^{\wedge}, 109,110$

subangustata (Graphis) 18^,58

subasahinae (Graphis) 88, $108^{\wedge}$

subchrysocarpa (Graphis) $16,19^{\wedge}, 26^{\wedge},[28], 36^{*}, 65,74$, 91, 110

subcinerea (Graphis) $19^{\wedge}, 22^{\wedge}, 60,98$ 
subclavulifera (Acanthothecis) $21^{\wedge}$

subcontorta (Graphina) 110

subcontorta (Graphis) $19^{\wedge}, 24^{\wedge},[28], 48^{*}, 110,116$

subcurva (Graphis) 18^,58

subducta (Graphis) 96

subflexibilis (Graphis) $19^{\wedge}, 26^{\wedge},[30],[31],[34], 46^{*}, 57$, 60, 60, 61, 98, 111

subglauconigra (Graphis) 19^, 114

subhiascens (Graphina) 111

subhiascens (Graphis) 19^ 25 $^{\wedge}$, [29], 50*, 111, 117

subintegra (Graphis) 18^,75

submarginata (Graphis) $19^{\wedge}, 24^{\wedge},[29], 40^{*}, 64,77,107$, $108^{\wedge}, 112$

subpulicaris (Graphina) 67

subpulicaris (Graphis) 18

subrufula (Graphis) 22

subruiziana (Graphis) $14^{*}, 16,19^{\wedge}, 26^{\wedge},[31], 51^{*}, 93$, $105, \mathbf{1 1 2}$

subserpens (Graphis) 60, 61

subserpentina (Graphis) 85

substriatula (Glyphis) 5*, 21^, [34], 63, 76, 77, 88, 105

subtartarea (Graphina) $18^{\wedge}, 84$

subtenella (Graphis) 15, 18^,63

subturgidula (Graphis) $19^{\wedge}, 26^{\wedge},[31], 46^{*}, 112,113$

subvestita (Graphina) 90

subvestita (Graphis) 19^,90, 90

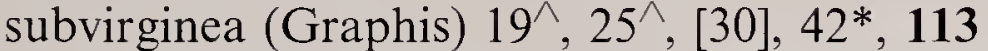

subvirginea var. rhizophorearum (Graphis) $18^{\wedge}, 68$

subvirginea var. streblicola (Graphis) 18^,68

sulcata (Graphina) 19^, 98

sulcata (Phaeographis) $19^{\wedge}, 114$

sulcatula (Graphina) $21^{\wedge}$

supertecta (Graphis) $19^{\wedge}, 24^{\wedge},[32], 37^{*}, 86,113,114,117$

supracola (Graphis) 62, $108^{\wedge}$

symplecta (Graphis) $19^{\wedge}, 24^{\wedge},[33], 47^{*}, 69,96,96,102$, 114

symplocorum (Graphina) 18^,80

tenella (Graphis) $15,15,19^{\wedge}, 22^{\wedge}, 22^{\wedge}, 25^{\wedge},[33], 38^{*}$, $63,78,114$ tenella var. abbreviata (Graphis) $22^{\wedge}$

tenella var. flavicans (Graphis) 22^

tenella var. jatrophae (Graphis) $19^{\wedge}, 115$

tenellula (Graphis) 19^, 24^, [29], 40*, 72, 108^, 115

tenellula var. eutypodes (Graphis) 19^,115

tenoriensis (Graphis) $19^{\wedge}, 24^{\wedge},[32], 48^{*}, 80,93,115$, 116

tenuescens (Graphis) 22^, 56

Thalloloma $10^{\wedge}, 11,83$

theae (Graphis) 19^, 117

Thecaria $10^{\wedge}, 15,83,99$

Thecographa $10^{\wedge}$

tongloensis (Graphis) 19

tonglonensis (Graphis) 105

treubii (Graphis) 19^, 117

triphora (Graphis) 11, 20, 94, 116

triphoroides (Graphis) 95

triticea (Graphis) 22

tuberculifera (Graphina) $18^{\wedge}, 56$

tumidula (Graphis) $19^{\wedge}, 21^{\wedge}, 26^{\wedge},[31], 44^{*}, 81,94$, 116

tumidula (Opegrapha) 116

tumidulella (Graphis) 22^,60

turgidula (Graphis) 19^, 105, 106

turgidula var. norstictica (Graphis) 19^, 90

vernicula (Graphina) $21^{\wedge}$

vestita (Graphis) 58

vestitoides (Graphina) 116

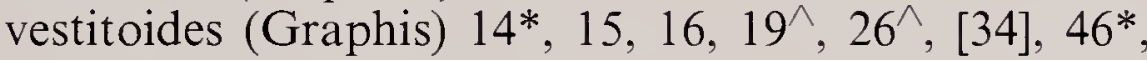
$56,59,111,116$

virescens (Graphis) $19^{\wedge}, 25^{\wedge},[30], 41^{*}, 58,73,78,95$, 109,117

virginea (Graphina) $21^{\wedge}, 113$

vittata (Graphis) $19^{\wedge}, 24^{\wedge},[32], 37^{*}, 114,117$

vulgaris (Opegrapha) 55

xylophaga (Graphina) 111

xylophaga (Graphis) $19^{\wedge}, 25^{\wedge}$, [29], 50*, 117 


